$$
\text { HF, } \begin{gathered}
2 S= \\
\text { ORNL-4824 } \\
\vdots \\
O K \\
\vdots
\end{gathered}
$$

RADIOACTIVE WASTE REPOSITORY PROJECT ANNUAL PROGRESS REPORT FOR PERIOD ENDING SEPTEMBER 30, 1972

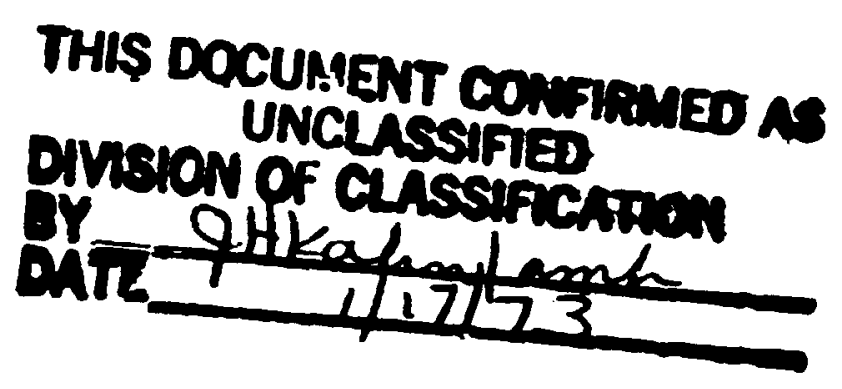

OAK 'RIDGE NATIONAL LABORATORY opgrater gr nign carbigh cogporation - gop the 
Printed in the United States of America. Available from A ational Technical Information Service

U.S. Degertment of Commerce

5285 Port Royal Road. Springfield, Virginia 22151

Price: Printed Cooy \$2.00; Microficte \$0.95

This report wos prepered as in eccount of mork sponsored by the United States Government. Neither the United Stotes nor tha United States Atomic Eneroy Commission, roor any of their employees, nor eny of their contractors. subcontractors, or their employees, mokes any nurr ity. express or implied. or asa hes sny legd libility or responsibility for tive accuracy, completeness or usefulmes of any information, apperatus, preduct oi prouss disclosed, or represents that its use would not infringe privately owned rights. 
Contract No. W-7405-eng-26

RADIOACTIVE WASTE RBFOSITORY PRC.TECT ANIUAL PRCGRESS REPORT

FOR PERIUD EIDIIG SFPTBMIERR 30, 1972
A. L. Boch, Project Director
J. 0. Blomeke, Assis ant Director
W. C. Mclain, Assist i Director
B. F. Bottenfield, Project Bngineer

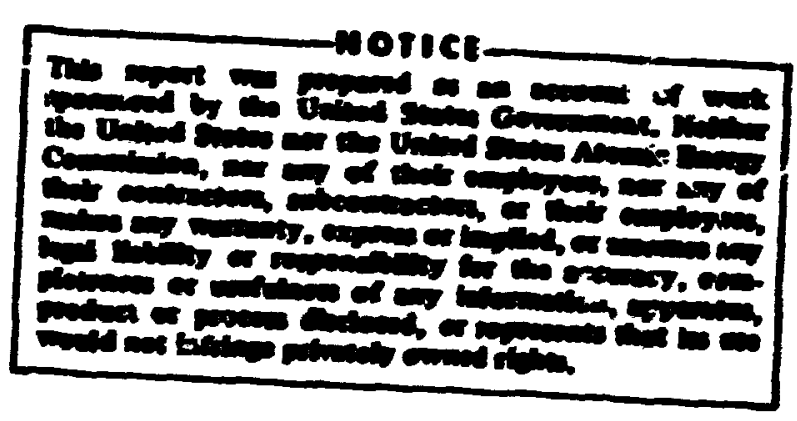

DECEMBER 1972

\footnotetext{
OAK RIDGE RATIOHAL LABORATORY

Dak Ridge, Tennessee 37830

operated by

UIION CARBIDE COKPORATION

for the

U. 8. ATOMIC ENIRGY COMAISSIOH
} 
CONTENTS

$\underline{\text { Page }}$

Sumbary . . . . . . . . . . . . . . . . . . . . 1

1. Introduction ................. 11

2. Geological Investigations ................. 14

2.1 Luons Site Investigaticns ............. 14

2.2 Alternative Site Recrnnaissance in Kansas . . . . . . 60

2.3 Geological Alternatives study ............. 101

2.4 Natural Containment Studies . . . . . . . . . . 137

2.5 References for Section 2............... 170

3. Operational Safety .................. 176

3.1 Isotope Migration . . . . . . . . . . . 176

3.2 Radiation Bffects ................. 201

3.3 Thernal Analyses ................. 230

3.4 Bcological Assessent ................. 244

3.5 References for Section 3............... 245

4. Conceptual Design Studies ....................... 449

4.1 Pilot Plant Repository Concept . . . . . . . . . . . 249

4.2 Haste Pacikage Connector ................. 260

4.3 Retrieval Concepts .................. 262

4.4 Iner Integrity Studies ................ 262

4.5 Repository--Puel Reprocessor Interfaces . . . . . . . 263

4.6 Reference fur section $4 \ldots \ldots$............. 264

5. Filot Plant Bxperinental Progran . . . . . . . . . . 265

5.1 Transportation and Handling .............205

5.2 Bxperimental Proxran . . . . . . . . . . . 268

5.3 Retrieval of Directly Buried Waste . . . . . . . . 27c 
RADIOACTIVE WASII REPOSITORY PROJECT: ANNUAL PROGRESS REPORT FOR PERIOD ENDING SEPTEMBER 30,1972

SUMAARY

Introduction

Concerns about the long-term geologic stability of the salt formation at Lyons, Kansas, resuited in a search for an alternative site for the first radioactive waste repository and in a reassessment of the suitability of other geologic structures than salt for this purpose. He concluded that salt iormations continue to offer the best prospects; thus, following experimental confirmation of the suitability of a site, construction of a pilot plant repositcry in salt is flanned for the early 1980s. If the results of operating this pilot plant are uniformly favorable, the facility may eventually be converted into a fully operational, permanent repository.

This report summarizes the results of geological investigations at Lyors and the attendant investigations of alternative sites. Other topics included are: progress on the experimental phases of the program that are concerned with structural analyses of the geologic formation within which the repository may be located; studies of isotope transport by various mechanisms within the repository; considerations of the chemical and radiation effects near the buried wastes; calculations of the thermal conditions to be imposed as a consequence of waste burial; potential ecological effects: conceptual design studies of the pilot plant; and a description of the proposed pilot plant experimental program.

\section{Geological Investigations}

The geological investigations reported here were directed toward the following objectives: (1) confirmation of the suitability of the tentaiively selectea iyons site, (2) demonstration of the long-term integrity of the containment provided by those salt deposits, (3) identification of suitable alternative sites within Kansas, (4) a wore general evaluation of geclogical alternatives on a national scale, and (5) investigations of physical and mechanical properties of geolngic formations vital to the natural containment of wastes.

Lyons Site Investigations. - The basic questions relating to geologic suitability of the Lyons site concern (1) the effect of boreholes and potential dissolutioning around them, (2) the influence of previous hydrearlic mining activities in the area, and (3) the effect of possible future climatic variatiors.

To date there are five reported instances of salt dissoluticaing and subsequent subsidence of land around boreholes in central Kansas. In all cases, abandoned oil wells serve as conduits carrying fresh water from 
shallow aquifers downward into the salt where dissolutioning occurs. The resulting brine then migrates to a deeper permeable zone below the sait.

Laboratory investigations and mathematical models have been utilized (1) for calculating the rates of salt removal, (2) determining the shapes of ensuing cavities around boreholes, and (3) aefining the mechanism of salt transport in boreholes.

Methods and materials for plugging of boreholes haive also been studied. The critical factors to be tested in plugging cements are permeability, turability, and the bond between the formation and cement.

Bxcavations in the salt deposits in the vicinity of the tentatively proposed repository were studied to determine what effect they might have on the integrity of the formation. The nearby American Salt Corporation's underground workings consist of mechenically mined openings in the rosk salt deposit as well as soluiion-mined cavities. The solution or hydrauiic mining operations, which consist generally of pumping fresh water into wells that penetrate the salt formation and withdrawing the ensuing brine, extend over an area of about 140 acres $\operatorname{sid}$ are situated approximately 3 miles south of the proposed location of the high-level portior of the proposed fedeial repository. It is estimated that only 5 to $7 \%$ of the salt has been remored from the area. Furthermore, cavity closure and the resulting land subsidence within the area are expected to proceed at a very slow ra?.e. In an attempt to enhance the removal of salt within the solution extraction area, two wells, $600 \mathrm{ft}$ apart, were connected by hydrawlic fracturing. The test was terminated when input fluids were found to greatly exceed fluid recoveries. Although the exact disposition of cne unrecoverable fluids is unknown, tests showed that the fractures in the vicinity of the injection and recovery wells were slibsequently healed, and that the test apparently did not cause significant changes in the impermeable nature of the salt deposit.

The mechanical mine of the American Salt Corporation extends over an area of about 375 acres and has been developed at the same stratigraphic level as the nearby abandoned Carey mine. Deformation of the rocks in and above the two mines is expected to continue at a very slow rate without the development of throughgoing fractures and faults.

Recently, an apparent plusged oil and gas test borehole of unknown origin was encountered unexpectediy along a working face in the extreme western part of the mine. Since fluids oriy seeped from it for a short perind of time after ii was encountered, it is indoubtedly not presently connected with overlying or underlying ground-water aquifers. Furthermore, in the event that the American mine should be inundated with water from this hole or any other perturbation, the underground workings at the proposed repository would remain dry since a 1500-ft-wide barrier of undj.sturbed rock sal.t separates the American and Carey mines. nally, by plugging all boreholes within the American mine area, any inrlowing waters would stagnate and extensive cavity growth would be precluded. 
Climatic variations represent a possible threat to the future integrity of the disposal formation. For example, an ice sheet entering central Yansas in the future kould flex the crustal rocks upward a few meters as it approached and would depress the crust by approximately $50 \mathrm{~m}$ if the site were overridden by the ice mass. Compressional, tensional, and shear stresses would be introduced into the sedimentary strata. Comparison of estimsted stresses with estimated strengths in the bedrock overlying the proposed repository indicates that the approach or overriding of an ice sheet would not cause deep fracturing of the strata; nor should stresses introduced into the bedrock by the Blacial loading lead to flowage of the salt.

Alternative Site Reconnaissance in Kansas. - The initial phase of the investigation of Kansas salt deposits for alternative sites was a screening survey performed by the State Geologizal Survey of Kansas. Eight county-sized areas were evaluated on the basis of (1) geology and hydrology; (2) population centers and densities, transportation facilities, and other cultural features; (3) location and status of oil and gas wells and estimates of potential for future development; and (4) the characteristics of the salt formation inferred from electric logs. Based on the information collected in this study, the eigat sites were ranked in order of suitability.

During the latter part of FY 1972 , a reconnaissance survey was made of three potential waste repositiory sites based on the recomendations of the screening survey. In general, the investigations at each of the sites consisted of field surveys to confirm l.x:al topographic surface geologic and cultural features and the studies associated with the core hole drilled at each site. These studies were: (1) stratig-aphic, using geophysical logs, cuttings analyses, and rig information; (2) hydrologic, based on packer testing within the holes; and (3) lithologic, based on examination of the cores obtained from the salt during drilling. The results of these investigations led to the rejection of one of the sites because of complications from high clay content, lack of lateral continuity of units, and suspected hydrologic problems. The other two investigated sites are suitable for further considerations, although the overall thickness of the salt is not as great as would be desired.

Geological Alternatives Study. - Additional geologic environments were considered as alternatives to the Kansas sites, and preliminary information was accumulated.

Within the Gulf Coast salt-dome province, there are approximately 263 onshore domes. All but 36 of these can be eliminated on the basis of various considerations. Adequate data for evaluation exists for only 4 of the 36 shallow, unused domes.

The Paradox basin contains a series of salt anticlines alioned in a northwest-southeast direction. Flowage is responsible for thickening of the salt in the anticlines; occasionally salt is intrusi.ve through the overlying sediments. Sait has been dissolved from the crests of piercement anticlines. 
The Permian salt basin has been relatively stable since Permian time, but shallow salt has been subject to dissolution - as evidenced by some karst development. In the southeastern New Mexico fortion of the Pcrmian basin, thick and pure beds of halite exist at the appropriate depth. This is the most promising area among those considered. Potential problems seem to be related to the oil potential of the area and to salt dissolution.

The Supai saj.t basin is a small area of Permian evaporites on the Colorado Plateau. The principal halite deposits occur as discontinuous units between a limestone below and the overlying Coconino sanastone; this is the principal aquifer of the region, and it is responsible for solution collayse features in the southwest part of the basin.

The Iuke salt body in the Basin and Range Province is an irregularly shaped salt mass of late Cenozoic age. It consists of at least 15 cubic miles of halite with shale interbeds underlying an anhydrite cap rock. Ground water in the vicinity is highly saline, irdicating some dissolution.

Evaporites of the Salina formation underlie a large area of the Michigan and Appalachian basins and consist of extensive salt deposits at relatively shallow depths in western liew York, northwestern Ohio, and the southeast and northern parts of the southern peninsula of Michigan. Strata both above and below the salt are occasionally waterbearing; however, in many areas, the salt beds are overlain by massive anhydrite and dolomite units or shales which are potential hydraulic barriers.

The Williston basin in the north-central plains contains evaporite beds at considerable depths, from 4000 to $12,000 \mathrm{ft}$ below the surface. Loral dissolution has taken place in the past, and large-scale removal of salt is thought to be occurring in the Canadian portion of the basin at present.

Argillaceous formations are widely distributed in the United States. Desirable features of some argillaceous sediments are high plasticity, high ion-exchange capacity, and extremely low permeability. A problem related to argillaceous formations is the possible generation of abnormal pore pressures by heating.

Three specific sites - the Gager mine in Tennessee, the Barberton mine in Ohio, and the Demopoiis cavern in Alabama - are located in calcareous formations. The first one cuntains some water; the other two are dry, but the potential permeability of the formation, if fractured, is a serious problem.

Naturel Containment Studies. - The natural containment of wastes is dependent on physical and mechanjcal properties of the geologic formatious in the vicinity of the disposal horizon.

A method for measuring thermal conductivity and thermal diffusivity of core samples is being developed, and the required apparatus is being 
fabricated. A transient-state plane probe and the required computer program are essentially ready for testing.

The mineralogy and possible dewatering mechanisms in all zones that may experience increased temperatures as the result of waste disposal operations require investigation. Multiple tests have been performed on shale samples from formations overlying the Hutchinson salt member in Kansas. On the basis of these analyses, the quantitative chemical composition and mineralogical composition have been defined. The quantitative mineralogical composition is obtained by means of a computer technique, currently under development, which utilizes a major eiements chemical analysis and a semiquantitative mineralogical analysis as imput.

Exper inental work on evaporites hes involved lineralogical determinations froin thin sections, $x$-ray analyses for deiermination of bulk mineral assemblages, and thermal analyses to define the dewatering characteristics of gypsum and whole rock samples. Results of $x$-ray analyses indicate that gypsum disappears as a major phase at a depth between 600 and $80 \mathrm{C} \mathrm{ft}$. From static heating tests, it can be concluded that gypsum dehydrates $\mathrm{r}$ apidly at $102 \pm 3^{\circ} \mathrm{C}$ at a pressure of $1 \mathrm{~atm}$, more slowly at iower temperatures, and is probably stable at $60^{\circ} \mathrm{C}$. The rate of dehydration is, in general, inversely proportional to particle size. In whole rock samples, weight losses decrease with depth, with samples from about $750 \mathrm{ft}$ containing from 5 to 20 wt \% water.

Occasionally, water pressures in pores of rocks are higher than hydrostatic. This usually happens in thick sedimentary sequences of Cenozoic age with abundant clay beds. The generally accepted explanation is the progressive luading of water-saturated sediments sealed by very impermeable layers. As the trapped fluids cannot escape, their pressure is increased, and consolidation of the sediments is prevented.

Additional mechanisms, for example, the diagenesis of argillaceous sediments with transformation of smectite to illite and mixed layer clay minerals, have been proposed as causes of abnormal pore pressures. However, at the present time, there is insuificient evidence to determine whether the dewatering of smectite minerals is actually a significant cause of abnormal pore pressures.

Two types of analyses are being carried cut to provide an estimate of the magnitude of rock deformation in the strata surrounding the repository. The semiempirical analysis, a computer model simulating in three dimensions the mechanical behavior of the strata and waste through time, vields general outlines and shapes of total deformations and identifies ereas where severe conditions may develop. The finite-elerent model provides details of displacements and strains in areas of interest. Laboratory determinations are made of rock properties (compression and tensile strength, steady-state creep, and static elastic properties) a.s input to the thermal elastic-plastic and viscoelastic finite-elenent modele. The elastic-plastic analysis has been aimed toward eraluation of variations in values of the elasticity modull and the tensile and 
compressive strengths of rocks with regara to stress behavior for short time periods. A coarse-mesh model has been satisfactory for displacement calculations, but a refined mesh is needed for stress analyses. The viscoelastic analysis has been utilized for evaluation of variations in values of the creep parameter, both transient and steady state, with regard to deformational behavior over long time periods.

\section{Operational Safety}

Isotope Migration. - Resulis of investigations of the transport of water vapor through crushed salt beds indicate little or no alteration of the bed in instances where condensation does not occur, but signifizant modification of the gas transport charasteristics of the bed, including plugging, in regions about and above areas of condensation. While not i.nvestigated, effects of hole closure on a crushed salt column contained within a hole in a bedded salt formation are expected to alter the observed behavior of water vapor transport appreciably.

A search of the literature for data concerning the establishment of flammability iimits for hydrogen-air mixtures in unconsolidated porcus media, such as beds of crushed salt, has yielded no information having direct application. However, if several reasonable approximations are made, it appears that the use of crushed salt backfill of suitable size characieristics would completely exclude the possibility of hydrogen-air expiosions. On the other hand, conclusions regarding flammability limits in backfili comprised of very coarse, as-mined crushed salt canriot be established on the basis of currently available data.

Surface diffusion studies of $\mathrm{La}_{2} \mathrm{O}_{3}$ on polished $\mathrm{NaCl}$ surfaces indicate that the mechanism proceeds only on the submonolayer scale and, at $420^{\circ} \mathrm{C}$, is characterized by a diffusion coefficient of about $3 \times 10^{-10^{\prime}} \mathrm{cm}^{2} / \mathrm{sec}$.

A series of experiments designed for studying the conditions to which solid wastes containing fission products or actinides would be subjected during exposure to crushed salt backfill is being performed. In the initial experiments, waste containirg $137 \mathrm{Cs}, 100_{\mathrm{Ru}}$, or plutonium was placed at about the midplane of a coluinn of crushed salt. The transport of isotopes up or down a given column is monitored by scanning each column at about 1 -month intervals. The colurns containing $137 \mathrm{Cs}$ and $106_{\mathrm{Ru}}$ are held at $340^{\circ} \mathrm{C}$, while the column containing plutonium (which is now being dismantled) was maintained at ambient temperatures. The results show that, after about 6 months of exposure, no transport of cesium, ruthenium, or plutonium has occurred.

Radiation Effects. - he analyzed experimental and theoretical information on radiation daxnege and energy storage in oxides and silicates, and concluaded that any energy storage in typical calcined waste oxides and glassy solids will result predominantly from displacements or "spikes" caused by elastic collisions of the heavy recoiling nuclei that are formed in the alpha-disintegration of the transuranic elements withir the wastes. 
Energy storage in the radioactive wastes is likely to be less than $200 \mathrm{cal} / \mathrm{g}$, but the possibility that it will be higher in some systems cannot be excluded. Temperatures greater than $1000^{\circ} \mathrm{C}$ may be needed to effect the release of all stored energy from some wastes. The release wili not be spontaneous unless there is a stepwise increase in temperature tc a inigh level at which rapid release is initiated. Radiation damage in radioactive westes can be investigated experimentally with synthetic wastes, using fast-neutron irradiation under conditions which can be achieved in the Cak Ridge Research Reactor.

We designed and constmucted a Roux-type drop (to high temperature) calorimeter for use in our experimental wurk with synthetic wastes. The accuracy and the sample size requirements of this device at the high temperatures $\left(\sim 1000^{\circ} \mathrm{C}\right)$ that may be required with the wastes are being investigated in calibration irans. Results to date indicate that the calorimeter will be satisfactory for measurements at 1000 to $1200^{\circ} \mathrm{C}$ with samples weighing about $100 \mathrm{mg}$. It should be possible to determine the stored energy with an accuracy greater thar $\pm 1 \mathrm{cal} / \mathrm{g}$, which will be adequate fo: our needs.

We initiated a program of experimental studies aimed at establishing the amounts of stored energy in rock salt under repository conditions (maximum ganma-ray doses and intersities of $\sim 2 \times \div 0^{11}$ rads and $\sim 5 \times 105$ rads, hr at temperatures ranging up to about $\left.330^{\circ} \mathrm{C}\right)$. We have designed and are constructing equipment for making experimental garma irradiations of salt witr.in the target region of spent HirIR fuel elements. Using the drop calorimeter at $500^{\circ} \mathrm{C}$, we determined the stored energy in samples of synthetic crystals of $\mathrm{NaCl}$ which hacl been gamma-irradiated to $1.5 \times 10^{10}$ rads at $10^{7} \mathrm{rads} / \mathrm{hr}$ and at $95^{\circ} \mathrm{C}$. Our average value of $14.6 \mathrm{cal} / \mathrm{g}$ exceeded, by factors; of 1.7 to 2 , those reporied by other investigators who used heat-of-scilution calorimeters. It is also much higher than the values, dpproximately 1 cal/g, previously reported by Sonder and Lindenbaum for synthetic salt crystals that had been irradiated at $580^{\circ} \mathrm{C}$ to cormarable doses, but at higher dose rates ( $>10^{9} \mathrm{rads} / \mathrm{hr}$ ), with van de Graaff electrons. The explanation for the latter discrepancy remains to be established. However, it is conceivable that $a$ dose-rate effect exists, in which migration and clustering of defects into relatively stable aggregates (colloids) become important at the longer exposure times prevailing at the lower dose rates. The difference between the results of the twc calorimetric methods can be reasonably explained by assuming that aqueous dissolution of radiation defects in $\mathrm{NaCl}$ results in the formation of certain species in addition to $\mathrm{Na}^{+}$and $\mathrm{Cl}^{-}$. The heat of formation of these is less than that of $\mathrm{Na}^{+}$plus $\mathrm{Cl}^{-}$so that some of the energy associated with the defects is not measured in a heat-of-solution measurement. The possible products of the dissolution of the raciation defects which are consistent with available in:ormation include $\mathrm{H}_{2}, \mathrm{ClO}_{3}^{-}$, and $\mathrm{H}_{2} \mathrm{O}_{2}$.

Two different samples of brine from the Lyons salt were analyzed for $\mathrm{Na}, \mathrm{Mg}$, and $\mathrm{Ca}$ by emission spectroscopy. The results were in egreement within the precision of the analytical method, $\pm 5 \%$. Also, these results 
were consistent with information on the solubility of $\mathrm{NaCl}$ in solutions of $\mathrm{MgCl}_{2}$ and with previous information on the composition of brine inclusions in a mine at Hutchinson, Kansas. However, it is notable that the magnesium concentration is $2.1 \mathrm{M}$ rather than the maximum of $3 \mathrm{M}$, which we previously estimated. Accordingly, the maximum rate of formation or $\mathrm{HCl}$ from the hydrolysis of $\mathrm{MgCl}_{2}$ is about two-thirds of the previous value. Several experiments were made on Lyons salt to obtain estimates of the pressure of gas within the gas-phase bubble, which is generally part, of a brine inclusion. These experiments consisted of tapping in -nclusion with a 20-mil drill and otserving the effects on the behavior of the gas bubble. We concluded that the gas pressure within a cavity is 1 atm or less. Also, we concluded that the maximum concentration of air within the brine will be about $0.002 \mathrm{M}$, and accordingly, that the effects of this air on raaiolysis will be $\bar{n} \in g l i g i b l e$ relative to the concentrations of radiolytic products $(>0.01 M$ at the least) with which we are likely to be concerned.

It is necessary to establish the combined effects of the thermal and nuclear environment on the materials surrounding the waste containers. We have completed measurements of the thermal conductivity, $\lambda$, of both "fine" and "medium" salt powders in a radial heat flow apparatus. The results showed that $\lambda$ is sensitive to the gas phase and to imposed stresses. This latter effect will be further investigated in a notpress apparatus to deterrine the time-temperatire-pressure dependence of $\lambda$ as salt powder is restructured. Another experimental program will determine the effects of dose, dose rate, and temperature on the $\lambda$ of solid salt.

We employed an instrumented probe in a salt block to simulate the short-time behavior of a waste can in the repository as the hole is backfilled. From a reference temperature of $500^{\circ} \mathrm{C}$ in air, the waste container will experience a temperature rise to about $560^{\circ} \mathrm{C}$ in an empty hole, decreasing to about $260^{\circ} \mathrm{C}$ after the salt powaer is added. If a molten salt eutectic mixtire is poured around the container, the container experiences a momentary rise to about $560^{\circ} \mathrm{C}$ and then a rapid decrease to about $2.10^{\circ} \mathrm{C}$.

Thermal Analyses. - Parametric studies of the high-level facility were conducted for a 1000-rt deptin and the stratigraphy at the Lyons site, with room and pillar width, waste container array and spacing, and waste age and composition as variables. Preceding this effort, thermal conductivi:y--temperature dependence was included in the three-dimensional conduction code, and criteria associated with limiting temperatures were modified to achieve greater consistency. Room wi ths of 15 to $50 \mathrm{ft}$ and correspending pillar widths of 25 to $50 \mathrm{ft}$ were considered. The results of the analysis indicate a prefe:ence for the 18-ft-room, 30-ft-pillar combination (smallest permissible based on other considerations) because of a sienificantly higher maximum permissible net lcading surface density. The corresponding gross loading surface density for 10 -year-old wasto is akout 6 metric tons of waste nuclides per acre ( $158 \mathrm{kw} /$ acre). The per missible power per waste package is defendent on the age and thermal properties of the waste, the diameter of the container, the time dependence of the backfill thermal properties, and handling considerations. A reasonable upper limit appears to be $5 \mathrm{~kW}$ for 10-year-old waste. 
A parametric analysis for a 2000 - $\mathrm{ft}$ depth snd $\varepsilon$ stratigraphy representative of southeast ivew Mexico was initiated. An 18-ft-room, 60-ftpillar combination with 10-year-0ld waste has thus far been considered. The maximun permissibie gross and net surlace densities aie about $8 \%$ lower an $50 \%$ nigher, respectively, than corresponding values lor the 18-ft-room, 30-ft-pillar combination at a deptr of $1000 \mathrm{ft}$.

himerous other miscellaneous calculations were made, all of which tend to substantiate the technical feasibility of the high-level waste repository.

\section{Conceptual Design Studies}

Following the completion of a draft conceptual design report for a repository located at Lyons, Kansas, a decision was made to withhold temocrarily the selection of a site and pursue the cunceptial. design of a pi int plant repository (PPR). The objectives of the PPR are to resolve majur concerns with regard to long-term storage of wastes in geologic formations by in-situ demonstration and to develop design and operating information applicable to the design of a full-scale repository. The PPR is assumed to have a life of 10 to 15 years, and the estimated number of waste packages to be buried (all in sleeved holes) in the salt formation is about 400 .

The PPR will include all facilities necessary to handle safely waste casks and packages, lower the pacikages into the mine, and dispose of them in sleeved burial holes. These facilities will include a waste receiving building and waste shaft; a man-and-material and salt hoisting shaft; an up-cast ventilation shaft and mine exhaust filter station; mine-level support, service, and maintenance facilities as required; minimal surfacelevel salt loading facilities; a mine operations and administration building; and minimal surface-level support facilities. The tentative schedule includes a conceptual design study to be completed in March 1975, based on a site in southeastern New Mexico, and design and ccnstruction of the PPR to be completed during the early 1980s.

The development of a connector for use in remote haudling of waste containers is under way. A prototype has been fabricated and successfully strength-tested. A conceptual stidy of waste package retrieval from both bare salt and sleeved holes has teen completed. A desk study of candilate matcrials for use as sleeves in the PPR burial concept has been made; experimental testing of one or more of these materials is planned.

\section{Pilot Plant Experimental Program}

The jilot plant will be operated to achieve two goals: to demonstrate the ability to transport and handle high-level waste at a salt-mine repository without mishap, and to confirm various technical aspects bearing directly on the operational and long-term safety of the burial scheme. 
only enough waste need be buried to accomplish these goals; however, all of this waste imst be readily retrievable.

We estinate that approximately 100 waste packages will be adequate to, demonstrate the transportation and hindlinf aspects, and that an acditional 200 to 300 packages will be required for specific experiments. All but 10 to 20 of these packages will be doubly contained and placed in sleeveri hoies in the salt to facilitate rapid and positive retrieval. The remaining packifes will be buried directly in the salt without the seconiary container or the sleeve; and, in some cases, the primary container will be intentionally breached to allow early contact betices the waste and the crushed sait backfill. A specially developed overcoring device yill be availabie for retrieval of the waste packages buried directly in the salt.

The specific experimental programs, in adjition to the transportstion-handling phase; will cover the areas of heat reavoval, furmation and $r$ lease of explosire and noxicus gases, radioective r.uclide transport, and rock mechanics. The duration of these experiments is expected to be in the range of 5 to 15 years. 


\section{INTRODUCTION}

J. 0. Blomeke

As a direct consequence of the favorable outcome of nearly 15 years of laboratory and fieli experiments performed by ORLL in the investigation of bedded sals formations as a repository for high-level wastes, the AEC announced in June 1970 the tentative selection of the Carey Salt Company mine at Ljons, Kansas, as the site for the iirst federal repository for solid radioactive wastes. The jelection was "tentative" because it mas contingent on the outcome of additional work, mostly of a geologic nature, that was required to confirm the suitability of innt particuiar site.

The subsequent geologic investigations revealed two problem areas, both of which have bearing on the long-term geologic integrity of the proposed Lyons site and are related to man's recent activities in that area. These problem areas were concerned with (1) dissolutioning of the salt formation ky ground water flowing down abandoned, inproperly plugged oil and gas welis into rermeable aquifers underlying the salt; and (2) the past, present, and future operations of the ncarby American Salt Corporation, which include hydraulic as well as mechanical mining of the salt for commercial purposes. Although our ongoing investigations gave promise that these concerns could be successfully resolved from a technical point of vier;, a rather formidable array of public officials, including the Governor and many members of the Kansas congressional delegation and the State Assembly, took positions opposing the use of the Iyons site. The residents of Lyons, who had previous exposure to this program during the course of the fleld experiments carried out there by ORIL during the 19608, staunchly supported us. Nevertheless, it becare apparent that a search for alternative sites in sait both within and outside Kansas should be implemented. The AEC also asked us for a nev assessment of possible repository sites in geologic structures other than salt.

In the meantime, the $A B C$ announced a thres-pronged approach to resolving the problem of high-level waste management. First, the Atlantic Richrield Hanford Caxpany (ARHCO) has been asked to design ourface storage 
facilities for construction at a site yet to be selected. These facilities will be adequate to store the high-level astes produced by industry until a completely acceptable method for their permanent storage or disrosal can be fully demonsirsted. Second, ORIL has been asked to continue the work on sait with the objective of obtaining all the supplementary information and exprience that are needed to verify its suitability. Finally, the Pacific Northwest Laboratory (PIL) has been asked to reassess ai? current and near-future possibilities for the permanent stcrage or disposal of high-level wastes. Cooperative prograns in investigative areas of mutual interest have been established with ARHCO and PIL.

We plan to have the necessary information availaile to make a firm recomendation to the ABC for acquisitfon of a specific site for a saltmune repository, regaraless of whether it is at Lyons or elsewhere, early in 1974. We also expect to have prepared, by June 1975, a concertual design, an Brvironental Impact Statement, and safety enalysis of a facility that will be constructed in the early 1980 s and will be operated initially as a pilot plant. During the pilot plant operations, all radioactive wastes will be explaced and maintwined in a fully retrievable condition wille confirmatory inforwation bearing on with operatioisal safety and long-term geologic containent is accrued. We envision that the results obtained from the pilot plant experience will pernit this facility to be eventucily converted into a fully operational, permanent repository.

The status of the aforenentioned geolcgical investigations of the Lyons site, including alternative sites in Kansas and other areas throughout the United itates, is presented in Sect. 2 of this report. Neasurements of physical and mineralogical properties of rocks from the Lyons site and descriptions of the calculational models that are being constructed to analyze the effects of stresses and temperatures in the overburden of a repository are also presented in sect. 2 .

In addition to the seolo/bical and rock mechanics investigations, a substantial effort is being made on a rariety of other tasks concerned with the design and operational safety of the repository. Invertigations of the tendency of radiolsotopes in the wastes to wove through crushed and 
solid sait are described in Sect. 3.1. The results of investizations, both experimental and theoretica] in nature, on the effects of radiation and elevated temperatures on the salt in the immediate vicinity of the buried wastes, as well as on stored exergy within the wastes themseives under storage conditions, are presented in sect. 3.2. The detailed calculations of the thermal conditions to be imposed on a repository and its immediate emvirons as a consequence of radioactive decay heat from the wastes are sumarized in Sect. 3.3, and studies of possible ecological effects of repository operation are discussed in Sect. 3.4. Sections 4 and 5 are devoted to conceptuai design studies of the pilot plant repository and to a description of the proposed pilot plant experiments? program, respectively. 


\section{GEOLOGICAL TNVESTIGATIONS}
W. C. $\mathrm{KcCl}$ ain
M. J. Ketelle
T. F. Lomenick
F. M. Empson

$$
\text { F. Gera }
$$

At the beginning of the period covered by this progress report, the various geologic investigations in progress were directed toward two basic objectives: (1) confirming the suitability of the tentatively selected Iyons site, and (2) performing analyses and evaluations required to demonstrate the long-term integrity of the containment provided by the salt deposits in that area. Early in the seriod, the confirmation studies highlighted two aspects of the site which seemed to cast some doult on its suitability: (1) the proximity of the American Salt Corporation's operations, especially their hydraulic mining activities, and (2) the number of oil-and-gas test wells drilled on and adjacent to the site. These problems and the various investigations associated with them are described in Sect. 2.1.

Because of these problems, the effort in the seologic investigations was largely reoriented toward the identification of suitable alternacive sites. The examination of potentially suitable areas in Kansas, which was carried out with the assistance of the Kansas Geological survey ard private consultants, is discussed in sect. 2.2. In addition, a broadly based investigation of geologicai alternatives to the Kansas salt deposits was completed. The U.S. Geological Survey and various consultan's participated in this study, the results of which are summarized in Sect. 2.3.

During this report period, all of the Lyons site confirmation studies not directly related to the salient problems were suspended, as were those related to natural containment analyses and evaluations that were specific to the Lyons site. The remaining analyses were broariened and generalized to be applicable to any aite. The progress on the latter studies is reportes ir sect. 2.4 .

\subsection{Lyons Site Investigations}

The initial objectives of the site investigations at Lyons were: (1) to confirm the suitability of the tentsatively selected site, and 
(2) to evaluate the long-tern integrity of the containment provided by the salt in the area. Two fundarental questions raised ouring these investigations were concerned with: (1) the influence of previous hydrauic mining activities in the area, and (2) the effect of boreholes and potential dissolutioning around them on the integrity of the salt. A more general question regarding long-term containment involves the potential effects of erosion and possible climatic variations in the future.

Rock salt deposits occur as discrete beds in sedimentary basins and are usually associated with other sedimentary rock types (e.g., shale, mudstone, carbonates, and coal). Generally the salt beds are underlain by thick accumalations oi these other sedimentary rocks wich possess varying potential for oil and gas development. Since the drilling of boreholes is essentially the only technique avallable for securing detailed information on the stratigraphy at any location, a given site considered for a radioactive waste repository may be expected to contain several penetrations. In an area of active petroleun exploration, the salt is frequently punctured by a large mumer of oil and gas test holes. Since these borings may serve to connect any or all of the rock formations penetrated in drilling and to provide a conduit for fluids contained in the strata, their nature and occurrence are of specir $\perp$ concern in the establishment of a radioactive waste repository.

There is little doubt that oil and gas torings can provide the framework for creation of subsurface solution cavities and hence instabilities in salt deposits where unique conditions prevall. There are several documented cases of such solutionizg accompanied by suriace subsidence within the central Kansas portion of the Permian basin.

To assess the effects of penetrating boreholes on the integrity and stability of bedded salt deposits, investigations have been initiatei to determine and define the natural (geologic and hydrologic) and imposed (boreholes) conditions fostering dissolutioning and to develop mathenatical models for predicting the rates and nature of carity fornation orer a range of expected field conditions. In addition, work has connenced on 
the development of materials and procedures for permanently plugging any boreholes that, if neglscted, might eventually promote dangerous instabilities in the salt. The results of this ivrestigative program are expected to permit the establishment of optimam land and mineral control limits for the pilot plant repository and to provide reasonable assurance that containment of the wastes will not be jeopardized by dissolutioning of the salt around boreholes. Sumaries of the progress made drifing the gear on the principal work areas of this program are given in Sect. 2.1.1.

In order to prevent the dispersion and/or rigration of radicactive waste after emplacement in salt, it is essential that the waste remain isolated from circulating fround water. All underground cavities excavated in rock salt formations can fill with ground water through improperly sealed shafts, boreholes, and other openings. Thus, as part of the safety evaluation program for the utilization of the proposed Lrons site, an assessment of the underground luining operations of the American Salt Corporation was wade. The implications of these workings on the proposed repository are discussed in sect. 2.1.2.

Since a portion of the radioactive wastes to be placed in the pilot plant repository must remain isclated from the biosphere for hundreds of thousands of years, estimates are needed of the erosion potential by stream action and glaciation and the effeats of these processes on the stability of the underlying sait formation for long periods of geologic time. A study has been made of the piobabilities of rates of erosion and loading by glacial ice in central Kansas; and, although the work has special significance for th.t area, the findings have general application throughout most of the stable mid-continent area of the United States. The results of a portion of this work are presented in Sect. 2.1.3.

\subsubsection{Borehole Dissolutioning and Plugging}

Dissolutioning of Salt and Iand Subsidence Arcind Boreholes in Central Kansas (T. F. Lomenick). - To date, five instances of salt dissolutioning and subsequent surface subsidence around boreholes have been reported in the central Kansas portion of the Permian basin. The most extensively investigated one is located in Russell County, approximately 55 miles northwest of Lrons. This sink, which includes a portion of 
U.S. Interstate Highway 70, was consequently investigated by the Kansas State Highway Department. According to their report, the land sturface has subsided at the rate of about $0.7 \mathrm{ft} /$ year and, since 1954 (wten the depression originated), has developed into a cavity spreading over an area of some 700 to $800 \mathrm{ft}$ in diameter with a maximum depth of about $20 \mathrm{ft}^{1}$ Exploratory drill holes into the sinkhcie have revealed that extensire dissolutioning has occurred in the upper part of the salt bed with subsequent collapse of the overiving Permian and Cretaceous age beds. Apparentiy, the sinkhole developed arvund a single oil mil that was first completed in 1936 and later converted to a salt-water disposal well. Records of the hole indicate casing deterioration in the salt zore and dissolutioning before abandonment. The prolific water-bearing Cretaceous sandstone atove the salt and the permeable production and/or disposal beds below the sait are the princip al geohydrologic parameters governing dissolutioning at the well. In 1957 a second sinkhole developed, about $1 / 2$ mile west of the aforementioned one. It, too, progressed from dissolutioning of the salt around an abandoned oil well, which was reported to have casing deterioration in the salt zone. As was the case for the nearby sink, a fresh-water aquifer exists above the salt and a disposal aquifer below the salt at the well site.

Sinkholes in Barton County and Rice County ere associated with dissolutioning in the salt around. oil wells that were later converted to brine disposal wells and then abandoned. As is the case for all of these features, the borings serve as a conduit for the overlying fresh waters to migrate downward where they contact the soluble rock salt; the resulting brine then migrates to a deeper permeable zone below the salt.

\section{Mathematical Modeling and Laboratory Investigations of Dissolutioning} of Rock Salt Around Boreholes (T. N. Dixon ${ }^{*}$ ). - An existing mathematical model, developed for use in soiution mining research studies, has been modified for calculating the rates of salt removal and the shapes of the ensuing cavities around boreholes. Simulated infections of 5 to $500 \mathrm{gpm}$ for salt bed thicknesses of 200 and $400 \mathrm{ft}$ have been investigated using this model. In general, the results indicate that initially most of the salt removed will come frim the uppermost beds of the salt formation and that, even at the low rates of influx of water, a "morning glory" effect 
will be developed. With a flow rate of $5 \mathrm{gpm}$, the cavity shape after about $i$ year (or when the wulk fluid in the cavity becomes saturated) is calculated to be as follows:

\begin{tabular}{cc}
$\begin{array}{l}\text { Distance from Top of } \\
\text { Salt Formation (ft) }\end{array}$ & $\begin{array}{c}\text { Diameter of } \\
\text { Cavity (ft) }\end{array}$ \\
\cline { 2 - 2 } 1 & 86 \\
3 & 35 \\
5 & 24 \\
10 & 13 \\
20 & 7 \\
40 & 4 \\
80 & 2 \\
120 & 1 \\
160 & 1 \\
200 & 1
\end{tabular}

Using a 500-gpm rate it was found that, after a period of 128 months, the cavity diameter at the top would be $2970 \mathrm{ft}$ and the concentration of rluid in the cavity only 75 to $80 \%$ of saturation. Thus, with high rates of water inflow, extensive dissolutioning would be expected to occur laterally in the ufier part of the salt formation. Further modifications in the model are being made to caiculate cavity shape and sizes after near-saturation of the bulk liquid in the cavity occurs.

In the case of boreholes that penetrate underlying aquifers having potentiometric hiads which rise into the salt, beds, dissolutioning of the salt can occur without the inflow of waters from overlying aquifers. Experimental as well as matrematical simulation techniques have been employed to determine the rtachanism of salt transport in such well bores. In laboratory tests, salt tlccks and flasks of satirated salt water were connected to fresh-water resurvoirs by small-diameter tubes. With tubing diameters of 10,3 and $1 \mathrm{~mm}$, it was found that the transfer of salt fiom the upper zones to the underl, ne, fresh-water reservoir is largely through free convection. Further tests usivg smaller-capillary tubing are pianned to determine the point at which free convection does not occur. In addition to the experimental work, a numerical model of the dissolution and transport process is being developed. The valiafty of this model will be determined by comparing the results obtained by using it with those obtained in actual exr:riments. 
Pluggirg of Boreholes (F. M. Jumson, T. Tamura). - To ensure protection of the salt from the action of water in aquifers above and below the salt bed, effective plugging of all penetrating borehules is necessary. In the vicinity of Lyons, Kansas, this requires that fresh-water aquifers above and dilute brine aquifers below be prevented from coming in contact with the salt in any way. The plugging procedures used routinely for sealing exhausted or dry oil and gas welis are designed primarily to prevent (1) drainage of fresh-water aquifers down unplugged holes to lower aquifers, and (2) salt-water contamination of the fresh-water aquifers by brines from high-pressure aquifers moving upward. State regulatory bodies normally specify plugging procedures and must approve the actual placement of the plug.

Many types of hardware and techriques are available for placjing cament and other materir ls in wells. They are used to seal off water-producing formations from oil and gas productions and to fix casing in place. However, the mure sophisticated techniques are seldom used in making the requjr:a plug of dry or depleted wells. The normal practice is to place the minimum-cost plug that will be accept,able to the regulatory body. It is the opinion of most individuals knowledgeable ' $n$ the field that such plugs are not very effective. If plugging operations are not properly carried out, the cement may fail to set completely and/or the plug may slip down the hole.

Discussions have been held with a number of individuals and organizations having experience in well plugging and cementing and/or in materials used in these operatinns, and a number of cements have been selected for laboratory testing. Two types of expanding cement were obtained from the Ideal Portland Cement Company; one of these was Type $S$ expanding cement (Ada, Oklahoma), and the other was Type III Stress-Bx (Portland, Colorado). Standard portland cement (Type I) was obtained local.4 for comparison purposes,

The purpose of the first test series was to determine the vater permeability of the selected cements when piepared according to the American Petroleum Institute Recommended Practice for Testing Oil-Well 
Cements (API RP 10B, 12th Ed., 1963). A water-cement ratio of 0.46 was used in all preparations. The plugs were sealed in steel pipe, using epoxy, and the system was pressurized at 100 psi with nitrogen gas. Distilled water was used in these flow tests so that the eluate could be analyzed for calcium ion content, which serves as a measure of durability of the plug. The results obtained are given in Table 2.1. In two cases, the cement was substituted with $50 \%$ pozzolan (flyash from the Tennessee Valley Aicichority steam plant at Kingston, Tennessee) in order to oiserve the effect of this additive on permeability and durability.

The data show that bott Type $S$ and Type III cements are superior to standard Type I portland. The permeabilitiy after 5 or 7 days of curing is lower for the expanding cements. Type III Stress-Ex appears to be extremely impermeable; in three of four test runs, no water flowed through the plus after $24 \mathrm{kr}$ at $100 \mathrm{psi}$. Data obtained from Core Laboratories, Incorporated (Dallas, Texas) on the permeability of several cores from Kansas show that the permeability of the formation is in the range of 0.3 to 0.1 millidarcy. Thus, plugs using expanding cements are less permeable than the formation.

The eluate was also analyzed for calcium ion concentration. When water continuously flows through set cerent, it will gradually remove the lime and in time destroy the cement. Consequently, a low calcium dissolution rate is a desired characteristic. The calcium data in Table 2.1 further support the use of expanding cements for plugging. The $\mathrm{pH}$ of the eluate is lower for the expanding cement, which is additional confirmation that smaller quantities of calcium hirdroxide are in solution.

Althougin the permeabilities of the cements are relatively low compared with the permeability of the formation, the formation-cement bond poses a problem in sealing open holes. It is common practice during drilling to use drilling mads to ald in the operation. These muds line the walls of the formation and will affect the bonding strength of the cement to the formation. The seriousness of the problem can be noted from the data in Table 2.2. All of the tests reported here, except No. 7, were conducted using Berea sandstone. 'The sandstone wns used to reserve 
Table 2.1. Permeability of Plugs, and Calcium Content and pH of Eluate, from Varlous Cements After Curling in $20^{\circ} \mathrm{C}$ Water

for Indicated Time at Atmospher1c Pressure

(Water-cement welght rat10 $=0.46$ )

\begin{tabular}{|c|c|c|c|c|c|}
\hline Cement & $\begin{array}{l}\text { Curing Time } \\
\text { (days) }\end{array}$ & $\begin{array}{l}\text { Flow Rate } \\
\text { (mi } / \mathrm{min})\end{array}$ & $\begin{array}{l}\text { Fermeability } \\
\text { (millidarcy) }\end{array}$ & $\begin{array}{l}\text { Calcium Content } \\
(\mathrm{meq} / \mathrm{ml})\end{array}$ & $\mathrm{pH}$ \\
\hline $\begin{array}{l}\text { Type I } \\
\text { portiand }\end{array}$ & $\begin{array}{r}5 \\
7 \\
19\end{array}$ & $\begin{array}{l}0.256 \\
0.035 \\
0.006\end{array}$ & $\begin{array}{l}0.85 \\
0.11 \\
0.02\end{array}$ & $\begin{array}{l}0.0028 \\
0.006 \\
0.0079\end{array}$ & $\begin{array}{l}11.0 \\
11.4 \\
12.2\end{array}$ \\
\hline $\begin{array}{l}\text { Type I with } \\
\text { 50\% pozzolan }\end{array}$ & $\begin{array}{r}5 \\
7 \\
19\end{array}$ & $\begin{array}{l}0.171 \\
0.47 \\
0.003\end{array}$ & $\begin{array}{l}0.55 \\
1.54 \\
0.01\end{array}$ & $\begin{array}{l}0.035 \\
0.003 \\
0.013\end{array}$ & $\begin{array}{l}12.1 \\
11.2 \\
10.4\end{array}$ \\
\hline $\begin{array}{l}\text { Type } s \\
\text { expanding }\end{array}$ & $\begin{array}{r}5 \\
7 \\
19\end{array}$ & $\begin{array}{l}0.032 \\
0.027 \\
<0.001\end{array}$ & $\begin{array}{l}0.10 \\
0.08 \\
<0.003\end{array}$ & $\begin{array}{l}0.0006 \\
0.0003 \\
0.0004\end{array}$ & $\begin{array}{r}8.1 \\
8.1 \\
11.8\end{array}$ \\
\hline Type III & 5 & $\begin{array}{l}\text { No How for } \\
24 \mathrm{hr}\end{array}$ & & & \\
\hline Stress-Dx & 7 & 0.01 & 0.02 & 0.0009 & 9.0 \\
\hline $\begin{array}{l}\text { Type III } \\
\text { with 50\% } \\
\text { poszolen }\end{array}$ & $\begin{array}{l}5 \\
7\end{array}$ & $\begin{array}{l}\text { No Nlow for } \\
24 \text { hr } \\
\text { No flow for } \\
24 \text { hr }\end{array}$ & & & \\
\hline
\end{tabular}


Table 2.2. Bonding Strengths of Type III Stress-Bx Cement Plugs to Formation (Water-cement welght rat1o $=0.46$ )

\begin{tabular}{|c|c|c|c|c|}
\hline $\begin{array}{l}\text { Test } \\
\text { No. }\end{array}$ & Core & $\begin{array}{l}\text { Core } \\
\text { Condition }\end{array}$ & $\begin{array}{l}\text { Pressure } \\
\text { (Ib/cm of surface) }\end{array}$ & Observation \\
\hline 1 & Berea sandstone & Dry core & 375 & $\begin{array}{l}\text { Formation broke before } \\
\text { any extrusion. }\end{array}$ \\
\hline 3 & Berea sandstore & Core prawetted & 290 & \\
\hline 4 & Berea sandstone & $\begin{array}{l}\text { Pretreated with } \\
\text { native muda }\end{array}$ & 100 & $\begin{array}{l}\text { Formation broke, but plus } \\
\text { partially extruded. }\end{array}$ \\
\hline $5 A$ & Berea sandstone & $\begin{array}{l}\text { Pretreated with } \\
\text { chemical mida }\end{array}$ & $<10$ & Plug easily extruded. \\
\hline $5 B$ & Berea sandstone & $\begin{array}{l}\text { Chemical mud } \\
\text { scraped off }\end{array}$ & 290 & Formation broke. \\
\hline $6 A$ & Berea sandstane & Replicate of SA & $<10$ & Plug extruded. \\
\hline $6 \mathrm{~B}$ & Berea sandstone & Replicate of 5B & 345 & Formation broke. \\
\hline $7 A$ & $\begin{array}{l}\text { Sandstone core } \\
\text { from Kansas }\end{array}$ & $\begin{array}{l}\text { Pretreated with } \\
\text { chemicel mad }\end{array}$ & $<10$ & Bxtruded. \\
\hline 7B & $\begin{array}{l}\text { Sandstone core } \\
\text { from Kansas }\end{array}$ & $\begin{array}{l}\text { Chemical mud } \\
\text { scraped off }\end{array}$ & 335 & Pormation broke. \\
\hline
\end{tabular}

Native mud is natural mud derived from the local formation and mixed with salt and water. Chemical mad consists of bentonite clay, starch, preservative, oll mixed with water, and salt. 
the linited supply of cores from the Kansas site for testing after the technique had been perfected.

Cores of Berea sandstone were drilled to provide holes $3 \mathrm{~cm}$ in diameter. Tre cement plugs were made using Type III Stress-Bx coment at a water-cement woight ratio of 0.46 . The water-cement slurries were poured into the holes and allowed to set for $24 \mathrm{hr}$ in a $100 \%$ relative humidity chamber. Then the plugged core was placed in a Carver press equipped with a plunger, and pressure was applied. Plugs that were set in cores without any and treatment bonded well to the surface. The bond strength is given in terms of pressure applied per square centimeter of plug-formation contact surface. About $300 \mathrm{1b} / \mathrm{cm}^{2}$ was required to cause failure. In each case, the formation broke before the plug extruded when no wad was used.

When rative mad (test 4) was used to coat the walls, the formation broke at $100 \mathrm{1b} / \mathrm{cm}^{2}$ after about $20 \%$ of the plug had extruded. On the cther hand, the pluss were easily extruded when chenical and was used (tests $5 \mathrm{~A}, 6 \mathrm{~A}, 7 \mathrm{~A}$ ); the pressure required was less than $10 \mathrm{lb} / \mathrm{cm}^{2}$. The extruded plugs shared a layer of and forming a skin around the plug. In each case, the and remaining in the core was scraped with a wire brush; then the core was replugged. Subsequently, the plugs bonded strongly to the formation (tests 5B, 6B, 7B). The weak bonding between the plug and the formation coated with the muds suggests that, in fleld situations, pretreatment will be required to remove the mad prior to cementing. Techniques that have been mentioned for improving bonding include: (1) plugging under turbulent slurry flow conditions; (2) using a washing fluid or mud to displace troublesome mad prior to cementing; (3) adding mid-kill agents to the cement slurry; (4) using latex cements and nonportland cement, such as Dowell Dexet, which can tolerate mads; and (5) mechanical scratching. Applicability of one or several of these techniques will be explored since most holes are drilled with sane addstion of mad. 


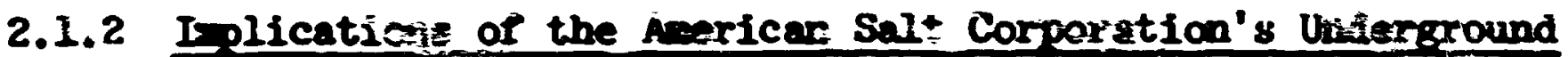 Dortings on the Proposed Federal Wiste Repository at ivrons, Xanses (T. F. Ioteritiv)}

The proposed site in Kanses for a federal waste repository is located northeast of Lrons, in Rice Cornty. Pigure 2.1 is a rap of the area showing the location of the facility with respect to the Civg of Lrons and to the underground workings of the American Salt Corpcration. In general, the initial plans for operation of the facility were to utilize a portion of the abandoned Carey nine for burial of tive alpha-conterinated or lowlevel waste, wile specially excavated spsce would be developed in the salt formation mortheast of the existing wine for burial of high-level, beta-gena raste. In Pig. 2.1 it is seen that the skaft to the American mechanical wine is about 2 niles south of the existing shart to the Carey ninc. Daring the 1930 s and 1940 s, an effort was made to connect the two nines by extending the Carey workings southward and the ferican nining northrard; however, with the cessation of operations at the Carey wine in the late 1940s, the project was abandoned. At this tine the two extensions were still approxinately $1 / 4$ wile apart. The Anerican Salt Corporation's hydrallic or solution mining operations are located to the south of the wining area, were a $1 / 2-$ ille-wide strip of undisturbed and unined salt is preserved between then and Anerican's nechanical workings (Fig. 2.1). The solution nining operations generally consist or puping fresh water into wells thet penetrate the salt formation and withdraring the rosulting brine. To increase the efficiency of these operations, hydrall1ic fracturing was used in 1065 in an attent to establish circulaicion underground between two brine wells located about $600 \mathrm{ft}$ apart. This single test, which proved to be unsuccessful, was conducted in the extreme southeastern part of the area about 3 niles south or the proposed location of the high-level part of the waste facility (Fig. 2.1).

Solution kining. - According to Vincent, ${ }^{2}$ the Loons Salt Company was organized in 1911 and a salt plant was erected apparently near the presentday location of the American plant, approrimately 1 alle south of Lyons. After a few years of operation, the ownership of the Lyons Salt Company was transferred to the American Salt and Coal Comany, which had general offices in Kansas City, Missouri. The plant has continued to sperate 


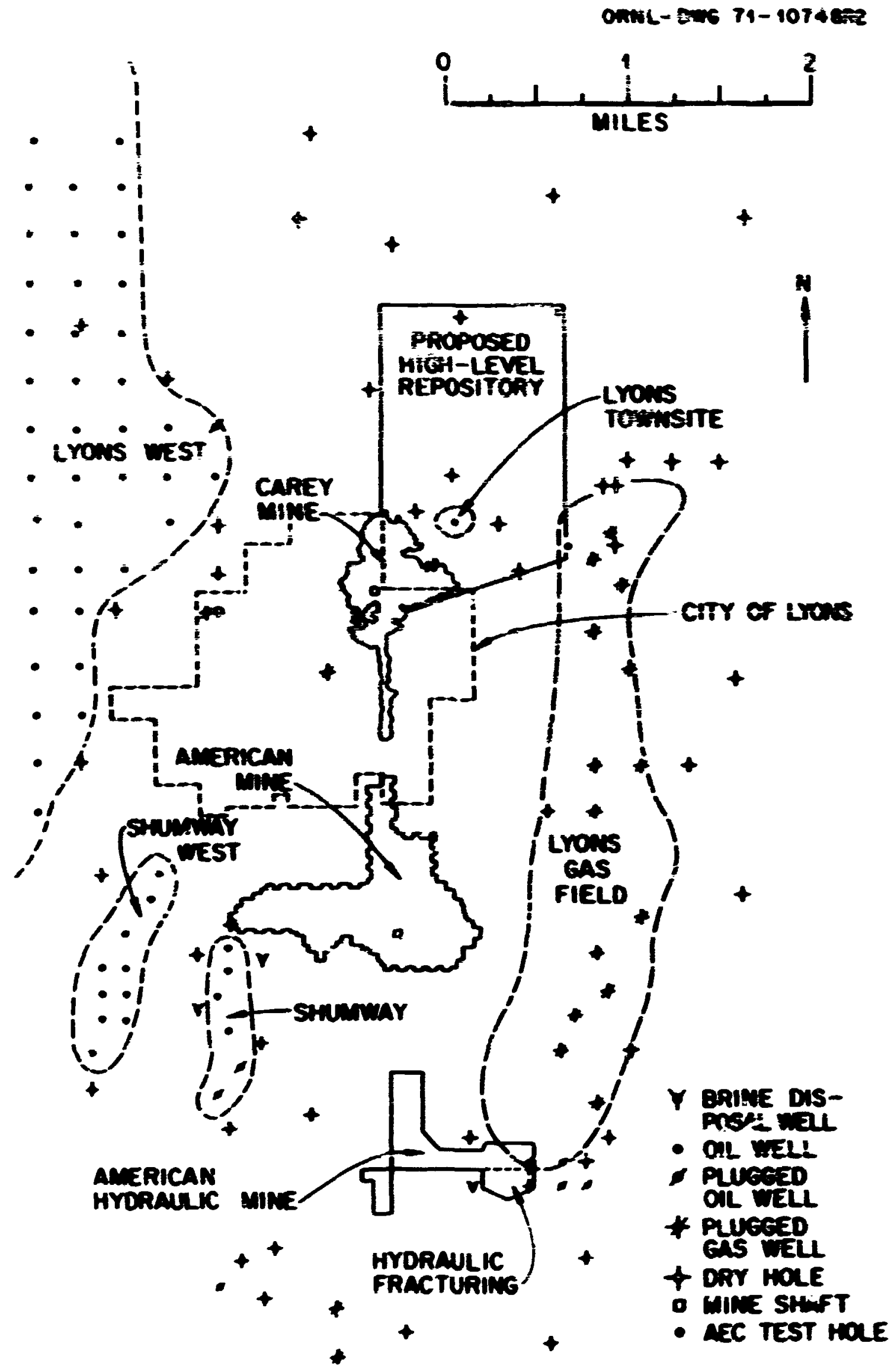

Pig. 2.1. Mep of a Proposed laste Repository Area, Showing Its Location with Respect to the City of Lrons, the American Salt Corporation's Underground lorkings, and Fearby oil and Gas Fields. 
under an aboreviated form of this company's newe fi.e., the Anerican Salt Corporation), even though tha: orgenization becase a part of the Cudahy Company in 1928 and Cudahy later (197i) werged with the General Host Company.

Frine wells have been used for alning sal $\bar{t}$ at the plant since the beginning of operation. A sketch (redram from an earlier one presented by the Averican Salt and Coal Company) depicting solution as well as mechanical zining is shove in Fig. 2.2. In solution or hyrauic minine, vater is punped down the yelis through an fmer casing that extends to near the bottice of the salt formation. The circulating water dissolves the salt, and ibe saturatid irite is brought to the surface through the annulus between the inner casing and the outer on (whick generally extends caly to the top of the salt deposit). Inis nethod of wining at the Acrican Selt Corporation has not changed apreciably fron the earis jears of operetion, although inprovenents have been made in such techniques as the driling of the vells, puping of nuids, and the eplacement of casing in the holes. Cenent has been used to bond casing to the wall rock at the mine since the early 19408.

Pigure 2.3 is asp of the solution pining area shouing the location of the brine wells. Fron the avallable data, it is not possible to estimate accurately the quantities of salt that have been removed frce the areas surrounding each brine well, or even from the soluticn aining area as a wole. (Nany wells were abandoned for indeterninate periods of tine before being plugged, and sane wells are known to be interconnected.) However, naxim or upper-level estinates of the quantities of salt removed from the area can be made indirectly by asswing that the plant operated at rull capacity curing its lifeine. This nethod of estinating indicates that only about 5 to $7 \%$ of the underlying salt has been removed fron the area. The plant cepacity was about $500 \mathrm{bbl} / \mathrm{day}$ (70 tons/day) for the period 1908-27. ${ }^{2,3}$ (Vincent ${ }^{2}$ states that the plant was opened In 1911, wille Otto Rueschhoff, current President of the therican Salt Corporation, judges that the plant has operated since abcut $1908 .{ }^{3}$ In order to preclude underestinatiof; the quantities of salt renoved rron whe area, the earliex date for comencing oratjons as utilized.) 


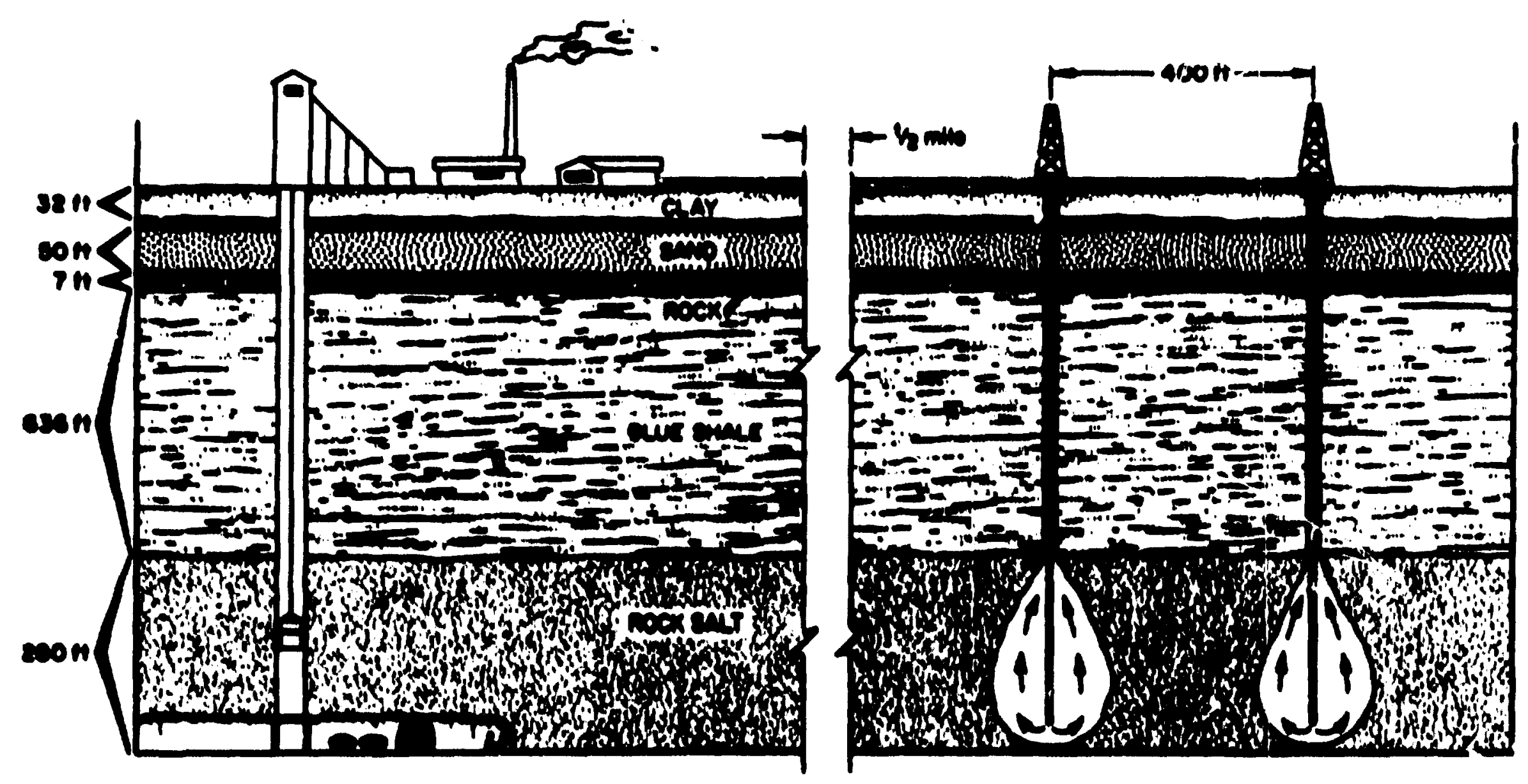

F16. 2.2. Bkotch Daploting Two Mothods of Mining salt at the Amorican Salt Corporation, Lyons, Ranses. (Redrain from an narly photograpls oupplied by the Nuricen salt and Coal Company in "P1t and avarry," p. 32, Ju2y 29, 1931) 

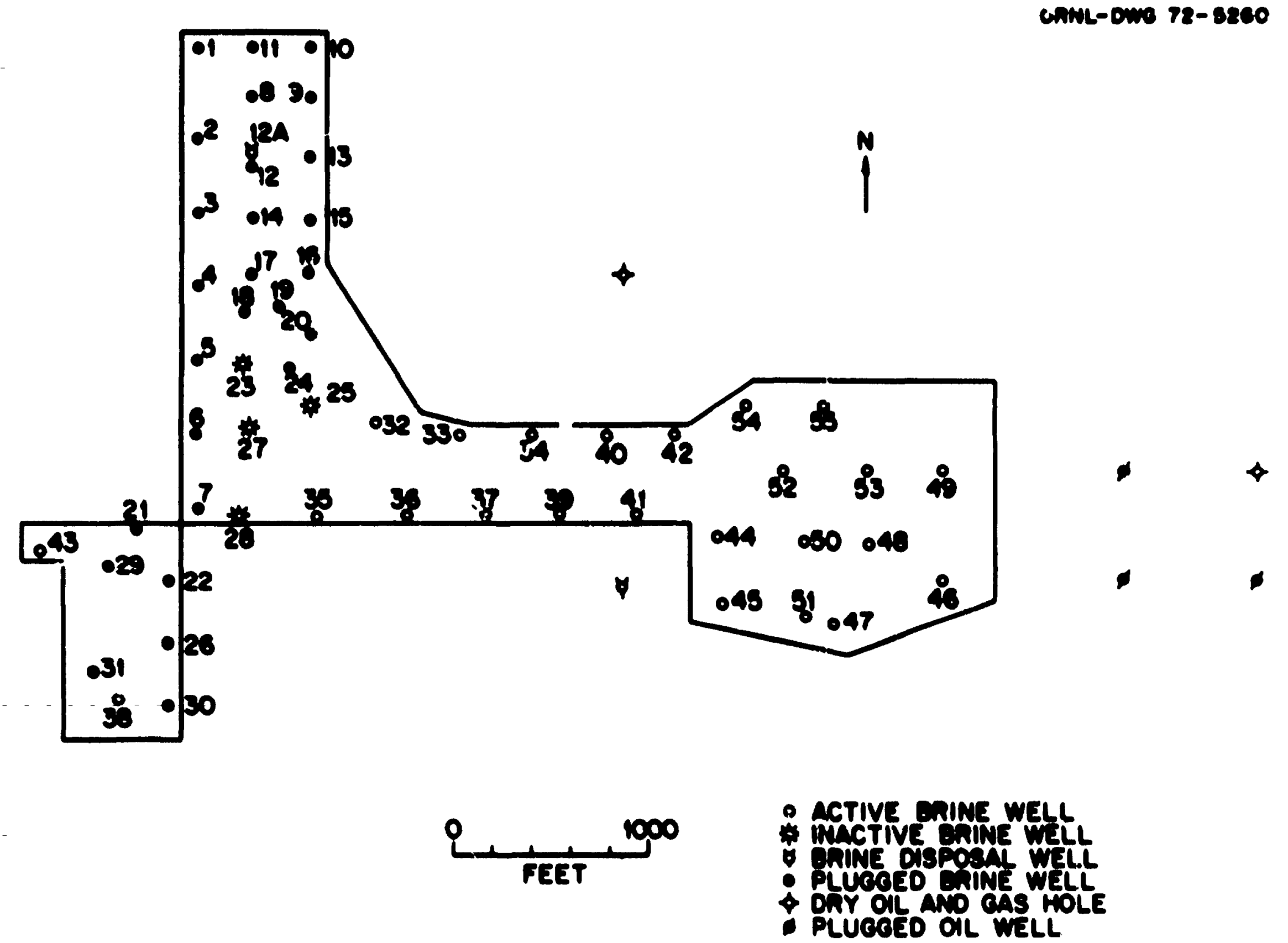

F1g. 2.3. Map of Solution Mining Area, Amoricen salt Corporation, Lyone, Kansas. (Redrawn trom map supplied to ORUL by the American Salt Corporation, December 1971) 
Thus the area enclosing wells 1 through 5 (Fig. 2.3), which were irilled and oper ted during this 20-year period, could have produced as much as $5 \times 10^{5}$ tons of salt or a gross cavity space of $7 \times 10^{6} \mathrm{ft}^{3}$. The thickness of the salt formation within the area aversges about $275 \mathrm{ft}$, with salt compising approximately $80 \%$ (or $220 \mathrm{ft}$ ) of the section and interbeds of shale and anhydrite the remaining. $20 \%$ (or $55 \mathrm{ft}$ ). Therefore, the original quentity of salt in the 10.5-acre area surrousiding wells 1 through 5 is estimated to be $7 \times 10^{6}$ tons, or $104 \times 10^{6} \mathrm{ft}^{3}$. With the renoval of $7 \times 10^{6} \mathrm{ft}^{3}$ of the salt, the area now contains $97 \times 10^{6} \mathrm{ft}^{3}$ of rock sal:, or about $93 \%$ of the original mass.

In 1928, the installation of evaporator pans at the plant resulted in an increase in capacity to 250 tons/day. ${ }^{3}$ subsenuently, the plant capacity was increased to 450 tons/day in 1968, and is expected to be expanced to 1000 tons/day by 1973. ${ }^{3}$ The area enclosing vells 6 through 55 covess appraximately 133 acres and originally contained about $1274 \times 10^{6} \mathrm{it}^{3}$ (or $86 \times 10^{6}$ tons) of salt. With a plant capacity of 250 tons/day for the period 1928-67 and 450 tons/day for the period $1968-71$, as men as $59 \times 10^{6} \mathrm{ft}^{3}$, or $4 \times 10^{6}$ tons (or $\sim 5 \%$ ) of the salt could have been removed from the area during that time.

For those areas in which the brine wells are still active, the quantities of salt removed from the formation can probably be estimated wore accurately by assuming that production at the average rate of $18 \mathrm{gpm}$ has continued uninterrupted since the wells were drilled. With this method of calculation, the amount of salt removed from the areas underlying the active wells totals about $3 \times 10^{6}$ tons $\left(44 \times 10^{6} \mathrm{ft}^{3}\right)$, or approximately $6 \%$ of the reserves of salt $\left(50 \times 10^{6}\right.$ tons or $741 \times 10^{6} \mathrm{f}^{3}$ ) winin the same area. It is or interest that this extraction ratio is In the same range as the estimates, using the maximum plant capacity values.

The available data indicate that 5 to $7 \%$ of the salt underlying the solution mining area at the American Salt Corporation mine has been removed. The shape and extent of the cavity space developed by this method of mining cannot be established with the available data, especially in 
the areas where the wells are interconnected; however, because of the single well injection and recovery system, it is concluded that most of che mired salt has been dissolved from the areas in ond immediately surrounding the wells, leaving relatively undisturbed salt in the midregions between welle. The areas of undisturbed salc are undoubtedly Greater between the more recent solutioning wells than between either the older ones or those where interconnecting passageways have developed.

The currently avallable data make it difficult to confidently predict the subsidence patterns that colild develog wthin the solutioil mining area; however, since from 93 to $95 \%$ of the sait in the fermation is still intact, extensive surface subsidence over large areas is not envision id. Indeed, no detectable sinks, depressions, or visible land surface subs:dence has wccurred to date; likewise, none has been detected above this mechanical mine. Furthermore, with the relatively small radil of tine dissolved cavities around the brine wells corpared to the large quantities of undisturbed, surrounding salt, cavity closure would be expicted to proceed through lateral flowage and at a slower rate than for the mechanicaliy mined openings at the American Salt Corporation, where about 70 to $75 \%$ of the salt in a relatively thin and laterally extending bed is removed and cavity closure would develop largely through vertical flowage. In the case of either bydraulic or mechanical miriting, the ensuing surface subsidence rill wost likely proceed at a very slow rate sno wil probably result in a general sursidunce of a few feet orer both areas without extensive fracturing and deformation of the overlying rocks. However, in the event that unexpected sollapse features and extensive surface subsicience should develop within ihe sclution mining aree, the perturbations could be confined locully to the solution-develojed savitjes and to the rucks and land surface immediately overlying them by sealifis and plugging the deep toreholes that penetrate underlying aquifers within the area (Fig. 2.i). Without, passageways to deeper, permeable rocks, any ground water infiltrating into the savities would quickly become saltsatirated and imobile (because of the higher density of the brine; and thereby preclude further: cavity growth. 
Finally, the 1/2-inile-wide barrier of undisturbed mat sait between the soluticn and mechanical workings of the American Salt Exporation, coupled with the 1,4-mile-wide barrier of undisturbed rock salt between the Carey mine and the American Salt Corporation's mechanical mine, would serve to frotect the proposed repository from any foreseeable ground-rater perturbations assoc? sted with solution mining.

Other 'mortant evidence for the expected stab:ility of the solution cavities at Lyons includes the absence of extensive land subsidence above the many cavities that have been developed in the futchinson salt nomer throughout central Kansas in the past 80 years. In addition to the extensive solution zining activities at Hutchinson and at frons, which have been in progress since 1887 and 1908 , respectively, salt has been extracted hydraulicully from vells near the cities of Sterling, Bloworth, lellington, Kinguan, and Anthony. 2 More recently, several bundred cavties have been developed in the salt for the storase of liquefied petrolen gases et iutchinson, Rago, Convry, and Bushton. 4,5 mos, although mans manmade solution carlties have been developed in the salt since its discovery, the cavities, as w'I as the rocks above then, have apparently resilined renurkably stable. The only documented case of subsidence attributed to solution wining is Kansas known to the arthor is that reported to have occurred around a salt well in the city of Butchinsen in the Ad-1Fe0s. 6 As recorded, the subsidense was centered around a brine wall and was apparently confined to a rougily circular area havize a dicater of about $600 \mathrm{ft}$. Alsc. It was observed that movenents at the land surface continued for about 2 months and resulted in a madran subsidence of about 1 ft.

In orjer to delineate wore preciselj tibe sizes and shepes of the existing cavities and thus provide the frmenork for confidently predicting subsicience within the area, it would be advisable to probe at leart sane of the active brine wells (and perhape even a few abandoned and plugged holes if they are reenterable) with sonar and other wireline devices. In addition, a series of holes could be drilled, losged, and probed in and around the solution mining area to deternine the nature and extent of any cavity development in the areas between and adjacent to the brine wells. 
Hydraulic Fracturing. - In the past two decades, hydraulic fracturing has been used extensively in some parts of the United States and Canada for cross-connecting vells for the purpose of salution extraction of salt. 7,8 Factures are generally initiated at the base of the solt by the application of hydrallic pressure through specially preparsd perforations that extend through the casing and for shart distances into the salt rock. Contimous puping then extends the frectures until somincation is obtained with the target wells. Sventawilly, 10w-pressure connections are made betreen connected welis and the systen becones fully operational. This solution extractica technique, comonly referred to as "rracing" in the salt industry, bas generally been found to be superior to the aingle-well injection and withdranl technique in that greater recoveries of salt are cbtained, brine concentrations are bigher, and lower development and operational costs are realized.

In April and $\mathrm{Kr}$ 1965, a single "fracing" test for the solutirn extraction of salt was made at the Anericen aibe. Inis abbreviated test Is believed to be the only one ever conducted in Alce County, even though "fracing" is reported to be used in salt uning operations in fono and sedgrick counties. 9 the location of the injection well (10. 47) end target wells (Wos. 45 and 46) for the teats are shown in Fig. 2.3. Figure 2.4 depicts the injection horizon, the locations of the well plugs, well casing particulars, and the stratigrephic sequances at tine two connected wells. A seen in P18. 2.4, the injection vell was drilled to a depth of $955 \mathrm{Ft}$, or to near the botton of the salt formation. Casing vas then set at a depth of $951 \mathrm{ft}$, end the ampular space between the casIng and the wall rock wa filled with cenont to the aurface. For the primary target well (W0. 46), which was formexly a ary ofl and ges test ho:.e drilled to a total depth of 3352 ft in 2949 , casing was set and ceinented at $689 \mathrm{ft}$. To isolate that portion of the bole which penetrates the salt fras the rocks below it, a cenent plus vas epleced from 976 rt to $1160 \mathrm{ft}$. The secondary target well (10. 45) was forwarly an sctive bribe wall. About I year before the test, it was drilled to the botton of the salt and casing ras set and crimated so a depth of 685 ft. After the Injection well hed been plugged at $914 \mathrm{ft}$, the casing wes perforated 


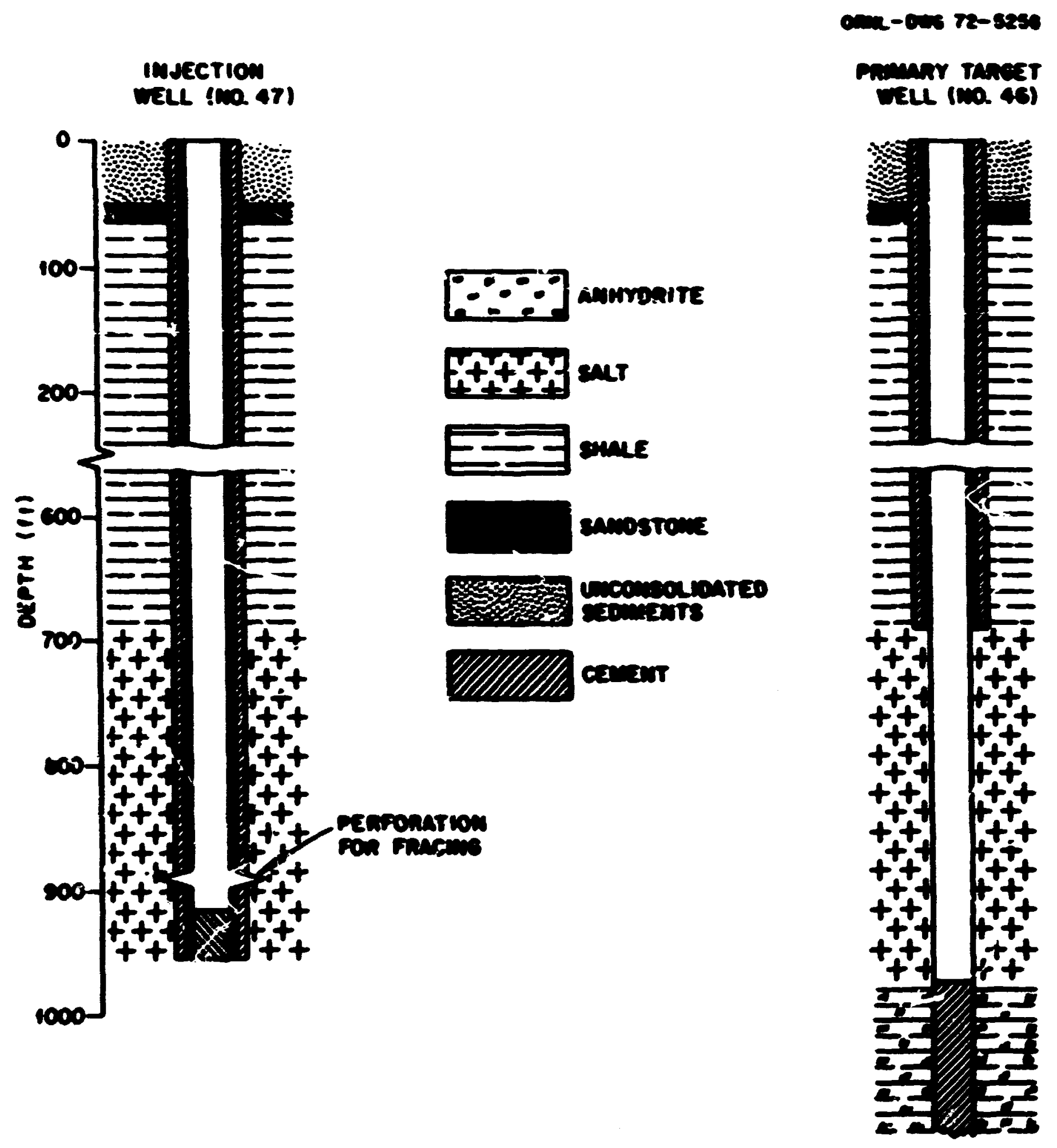

F18. 2.4. Ceneralized Crose sections of Injection and Inget inlls for livdreulic Frecturing lest inde at the Nericen salt Corporation iline, Lyons, Xenses. 
for fracing at $892 \mathrm{ft}$. Initially, a pressure of 1250 psig was established for "Pracing;" however, since no fluids (saturated brine) were taken, the pressure was increased to 2000 psi. At this time, the salt forwation began to accept fluids and aprarentily fracturing comenced. Immediately, the "fracing" pressures were iowered to 1250 psig and brine was pumped into the formation at a rate of approximately $200 \mathrm{spm}$. Within 5-3/4 in after puping irs initiated, a connection was made between the injection well and the primary target well. Fresh water was then funped at the rate of 170 to $185 \mathrm{~g}$, using an injection pressure of 645 psig, intc the injection well, and brice was renoved from the target well. To prevent precipitates from accumating in and around the well casing of the brine return well, flows were periodically reversed in the injection and target wells, at least for the flrst few days of operation. Injection pressures contimed to drop steadily from 645 psis to 465 psis during a period of approximtel; 13 dars after the connection had been ysie. This is indicative of a jradually developing los-pressure cross comectiod. However, on the 14th, 15th, and 16th days of operation, the volumes of brine recovered were, respectively, 14,600, 25,600, and 187,000 gal less than the rolwes of fresh water injected. Inis condition propted a halt in injections until tests could be made in the injection well tc determiue the condition of the cenent plug and to locate the fracture in the primary target well. The plug in well 47 was found to be in place and showed no evidence of leaking; nerertheless, it was not possible tc locate the fracture in well 46 with logging tools since a winanical obstruction was found in the hole at a depth of about $687.5 \mathrm{ft}$ (at or near the botton of the casing). After it had been cletermined that the fluids were not escaping into other nearby wells within the area, the project was abanconed.

Wth the available data concerning the fracing test, it is not possible to delineate precisely the nature and extent of the subsurface rock fracturing and thereby specify the exact disposition of all of the fluids. The nature and directions of fractures in rock fornations inftiated hydraulically throsigh perforated boreholes are largely unpredictarle unless some definable iracture behavioral patterns have been established for the formation through numerous previous tests. some of the more 
important factors that govern hydraulically induced fracture behavior in rocks include the nature of the initial perforations in the casing and rock, bonding of the casing to the host rock in the injection well, bedding characteristics of the rocks, and the in-situ state of stress of the rocks to be fractured. Even though few, if any, of the factors have been evaluatei for the American Salt Corporation test, it is apparent that some fracturing did occur in a horizontal or near-horizontal direction because a cross cownection was unmistakabiy made between twe wells iocaciea approximately $600 \mathrm{ft}$ apart.

In general, the pressure required to raise overburden will vary from 0.9 psi to 1.8 psi per foot of overburden. 7 The depth of injection for the American Salt Corforation test was about $890 \mathrm{ft}$; thus, botton hole pressures of from 800 to 1600 psi (ground-level pressures of 400 to 1200 psig) would be necesssry to maintain an open fracture. After the fracture had been initiated, pumping pressures of 645 to 450 psig were neasured. Thus, for the first 13 days of the test, essentially all of the injected fluids were prcibably channeled through fractures that existed between the two connected wells; however, possibly as the result of mechanical plugging of the passageway with reprecipitated salts and/or clay and otter ilpurities after the 13th day of operation, the fluids then probably began to fill other parts of the initial fracture by raising the overburden and/cr fracturing spread in other directions. (lio records of pumping pressures at the time of fluid loss are arailable.) Once the punging had been stopped and well pressures relieved (approximately 15,000 gel of Fluid was bled from the infection well to relieve the pressure), no further expansion of the fracture system occurred and the existing fractures undoubtedly closed via settling of the overburden and plastic deformation. The injected fluids would have been expected to dissipate by solution and inirusion into rock pores, leaving perhaps some small and isolated bodies of brine trapped in the rock mass.

In the summer of 1965 (a few months after the "fracing" test) well 46 (the target well) was converted into a convent: nal solution mining vell, according to Rueschhoff, by drilling out the obstruction at the top of the salt, which was epparently a 10- to 12-ft-thick layer of 
shale. ${ }^{10}$ Pressure testing showed that the fractures that had developed around the vell during the "fracing" tests had healed, and there was no ildicatiun of leakage of fluid from the single solution vell system. Approximaiely 2 years after the fracing test was abandoned, the injection well was respened and the wellhead pressure, which had remained constant at about 320 psig since closure of the vell imediately after the test, was relieved. This maintenance of pressure clearly indicates that the fractures around this well have also healed.

Nechanical Mining. - Figure 2.1 shows the location and extent of the mechanical workings of the American Salt Corporation. The shaft fo: this mine was sunk in 1918, and wining has continued uninterrupted since that time. The workings now extend over an area of approxinately 375 acres. ${ }^{3}$ The salt is mined by the rocm-and-pillar method; the latest and nost persistent pattern is one of 50-ft-square pillars and 50-ft-wide surrounding roos, wich produces a salt extraction of about 75\%. The mining level lies about $1000 \mathrm{ft}$ belor the surface and consists of a 9-ft-thick layer of sait containing a minimen of $95 \%$ sodiun chloride. This bed is precisely the sane one that was worker at the nearby Carey mine. In general, the rock section, including the salt, at the American mine is very similar to that at the Carey nine; hovever, since the Anerican mine lies at the northern extrenity (in Rice County) of the buried Arkansas River channel, a 50- to 75-ft-thick layer of wat.er-bearing sediments covers a large part of the land surface above it. To ensure th it these waters do not $f 111$ the wine when it is abandoned, the shaft should be plugged sinilarly to those at the proposed waste repository.

Tong-term subsidence of the land surface over the American mine will undoubtedly be mach the same as that at the Carey mine since the geologic framework is essentially the same at both mines and the mining methods and extraction ratios are comarable. With the relatively thick sections of salt (200 ft) and shale ( $500 \mathrm{ft}$ ) above the singie mining level at the two mines, it is expected that cavity closure will occur largely through plastic deforwation of the rocks and that land subsidence above the mines will proceed at a sisw rate, leaving a structurally displaced but inpermeable, protective rock cover above the salt. 
As seen in Fig. 2.1, the Arerican mechanical workings lie between

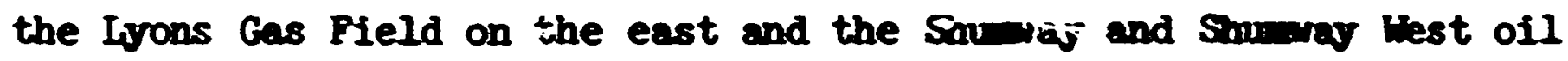
fields on the west. Essentially ail of the oil and gas test holes and wells in this region penetrate the salt rocks 25 well as the orerlying ena underlying aquifers. Thus, to prevent wine flocding, rather extensive sections of unined and undisturbed salt should surround these boreholes. In extending their workings westurard and near to the smuras oil field, the American Salt Corporation's pining plan was to leare at least a 200-ft-thich burrier of unined sait around any salt penetrating borcholes within the area. ${ }^{3}$ However, on April 19, $19 n$, brix.e, drilling ad, and cement were struck wile drilling a 7-ft shot hole horizontally into a working face near the vesternost extension of the wine. 11 since the nearest known borehole (Bolinger 10. 1) was recorded to be about $300 \mathrm{ft}$ to the south, the encounter was unexpected. Initiaily, finid flowed fron the hole at a rate of a few gallons per dimte; however, the discharge apparently slowed rapidly to a "fast seep" and after a fex months stopped completely. 12 In generai, the fuid contained bioh concentrations of sodiu, calciw, magnesiw, chloride, and sulfate ions. The high concentrations of sodive end chloride way be the result of contact of the fluid with the salt rock, whereas the calciwn, nagesiw, and sulfate lons probably reflect the presence of cement and drilling mad. To delineate the intrusion, 1-1/2-in.-dien holes vere drilled into the working face above and below the "discovery" hole. The intrusion was encountered after $12 \mathrm{ft}$ of penetration in the top bole and $15 \mathrm{ft}$ in the botton one, wile offet drilling established that it was about 18 in. in width. ${ }^{3}$ Undoubtedily, a carlty exists behind the morking face of rock salt since water was circulated freely between the three toreholes.

Regardless of whether the encountered hole 18 actually the Bolinger No. 1 well or sone other (unidentified at this tine) hole, the principal concern is that of present and/or suture nooding of the nine with veters from overlying and/or underlylng aquifers that have been penetrated in the drilling. At this ifre, it is certain that the borehole encountered in the mine 18 not open to fluids in the overlying and underlving aguifors. Apparently, the nuids that nowed from the hole for a short tibe arter 
it wes intercepted with the shot hole consisted of displaced, resi tual, or trapped meteriais from drilling and plugsing operations; hovever, in the event that the plug or seal nor in place in the hole should be faulty, leaky, or sthervise unserviceable, the wine will surely nood unless the seal is repaired or the hole is replugged since thi farmation vaters above or belx the salt could fill the wine within a relatively short period of tim.

Although nooding of the rine would undoubtedly represent a financial 1088 to the American Salt Corporation, it should not endarger the proposed vaste repository since $s$ 1/4-ille section of undisturbed salt separates the Carey voritings ron the Americar nine. Nurthermare, this barrier would remin essentially irtact because wy inconing Ruids would socm becone saturated and stagnent. Brines are bown to fill abandoned nines Whin $500 \mathrm{n}$ of the isse II salt dine repository for railosctive vaste in lest German. 13 Saturated brine has a density of 1.2 and canrot be displaced by frestei. solutions unless dreinage pathwars are provided to deeper depths. Perhaps the only concelvable paseagewn for the dowmard norenent of fluid in the frerican aine would be through open or umplugsed boreholes. Inus, by plugsing all boreholes within the fwerican Salt Corporation mine that penetrate the salt section and the permeable rocks belon it, the proposed vaste repository vould not be affected by the presence of this aine, even if nooding occurred.

Singry and Conclusions. - The Anericen Salt Corporation's underground workinus adjecent to a proposed repository at lvons include hydrwulically aned cavities as wil as nechanically developed excavations. Solution mining activities have been confined to an area of sout 140 scres, and It is estinated that rron 5 to $7 \%$ of the salt underilying this area has been renoved. Although the exact sizes and shepes of the carlties existing around the beine wells are not known, it is essumed that salt renovel has been createst adjacent to the bripe wells and that the enouing cavities have been at least partially filled with slabs and particles of sbale and anhydrite inpurities. To date, no visible land subsidence has occurred within tine aree and, because of the relatively anll frection of salt rewored, large-scale and spectecular deformations of the rocks above the 
salt formation would not be expected. Purtherncre, in the uniliels event that deep and extensive subsidence did derelop vithin the area, its localization and confinenent could be ensured by plugaing the feu deep boreboles that penetrate the aquifers underiying the salt within the area. Drese britholes would proride the only means for movenent and reoval of the dense brine waters tron the cavity area.

The single podivalic fracturing test conducted within the solntion dining area to conect brine vells vas terwincted after 16 day of syerstirg wen huid input rolumes sere found to greatls exceed huid recovaries. The umecovered Muids vere aparently dissipated bs solution and intrusica into rock pores, and perhaps even sone emall isolnted boliss of nuid were trapped in the formations ubea infecticns were hal ted and the raised overinden resettled and closed the frecteres. It bas been decontrated that the fractures around both the injection and recovery vells have bealed

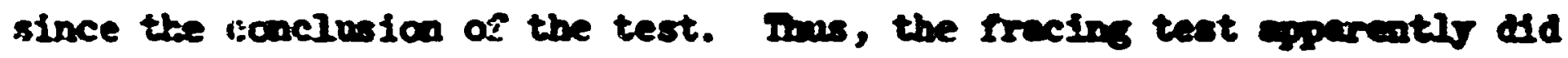
not create permont and opa. rractures in the salt or chnrge the if perresble nature of the salt within the area apprecibbly.

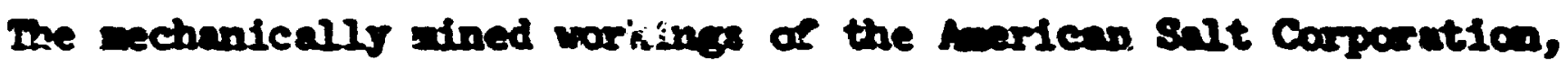
wich extead over an area of about 375 acrea, bave been deselopad at tine seve stratigaphic level as the abondored Cares aine, inicin is part of the proposed vaste repository. In addition, the two nibes hwe been developed using the rocm-and-pillar netbod of aning, with bout fis of the salt being renoved at the nining level and the reanining $251 \mathrm{cospls-}$ ing the supporting fillars. Uader these conditions it is appeted that deforzation within the wine will proceed at a slow rate ad the overvins

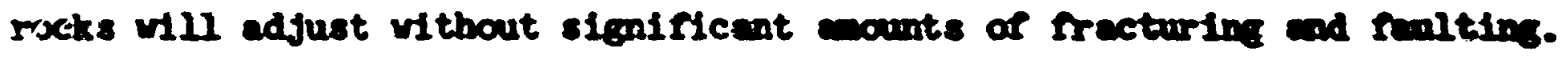
It is conceiveble that ground watre could enter the fmaricen salt corporatlon's wine ria lenkege at the shart or perthes through verion borebales that penetrate the selt faration, such as the one encourtered recantly along a working face in the extrowe western resches of the dine. Mrfective sealing of the shaft and nearbs borcboles would, of couree, preclnde the entry of vater into the alne throsgh these partorbations; homerer, evea If the wive should IIII with vater, the vater would not atorate into the repository due to a 1500-ft-ulde berrier of undisturbed roek selt scyereting 
the two existing aides. Furthernore, by plugsing all boreholes within the aining area, wich are the only pathways for the downdard movement of brine, aw vaters in the nine would stagnate and cavity growth would be orecluded.

Although the underground workings of the fmerican Salt Corporation ust be considered for an potential perturbation to a nearby repository, thes ant also be viewed as a distinct asset since the rechanically mined opentrye, as well as the hyirenlically developed cres, could serve as disposel bins for the several sillion lans of ipure salt that vould be gaversted from wining activities associated with the repository. The fliling of these unsed vorkings would also pronote further ground stanify and wininize land subsidence within the potentially affected rreas.

\subsubsection{Fotentiul Bffocts of Future Continertai Glaciation on the Proposed

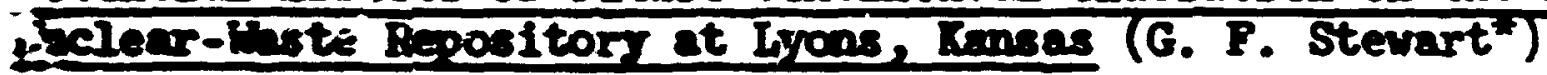

A besic escuption in this research is that the glacial age is still in F-ogreas, and that presently an interglecial interval prevails. For the scis of discussion of the potential effects of glaciation on the repository, the probability of axother episode of elaciation within the Uife-spen of the repository is ussured to approach certainty.

of the four gilecial stages of the Pleistocene, only the Nebraskan and ronsen fieciers advanced as far southward as Kansas. These glaciers extended only into the northeasternnost part of Kanses (FIgs. 2.5 and 2.6). Inforation contained in geological and geophreical literature and discussed belor sageets that, if continental glaciation should occur ouring the lifetive of the proposed repository and if elaciers should extend at least as far southward as the Kansan glacier, then bedrock in proxdrity to the proposed repository ufigt be affected to sone extent. An estimate of this effect is discusser. below. Potential changes caused of loading of glecinl ice may inelude:

(1) regional depression of the entire crust beneath the 1ce,

(2) fracture of the crust wear the margins of the glacters,

Departinent of Ceology, Oclahoma state University of Agriculture and Applied science, Stilivater. 
ORNL- DWG 72-10662

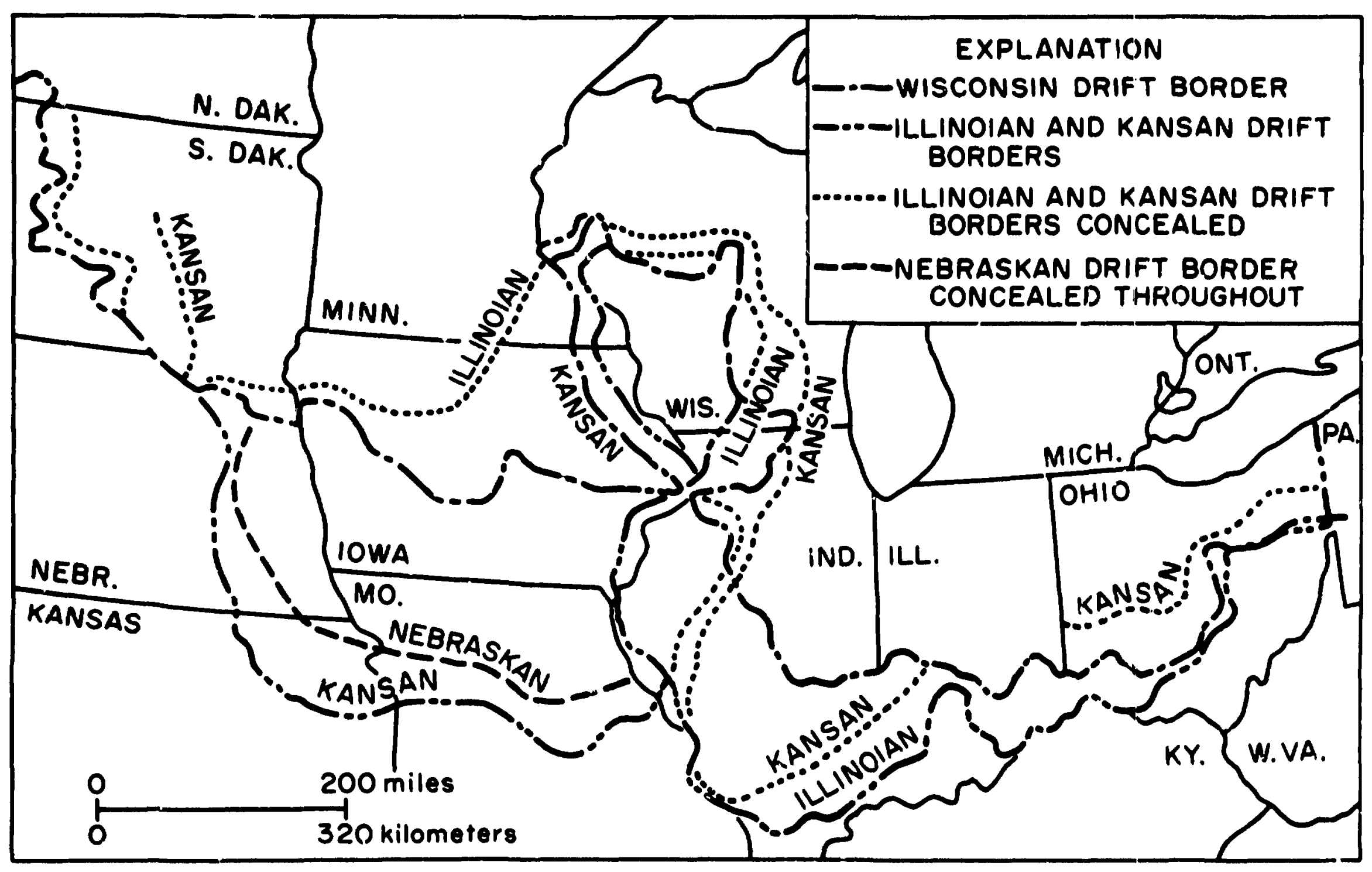

Fig. 2.5. Nebraskan, Kansan, Illinolan, and Wisconsinan Drift Borders in Central United States, Showing the Approximate Maximal Positions of Advancement of Pleistocene Continental Glaciers. (After R. F. Flint, Glacial and Pleistocene Geology, p. 338, Wiley, New Yor'k, 1957; 
ORNL-DWG 72-10663

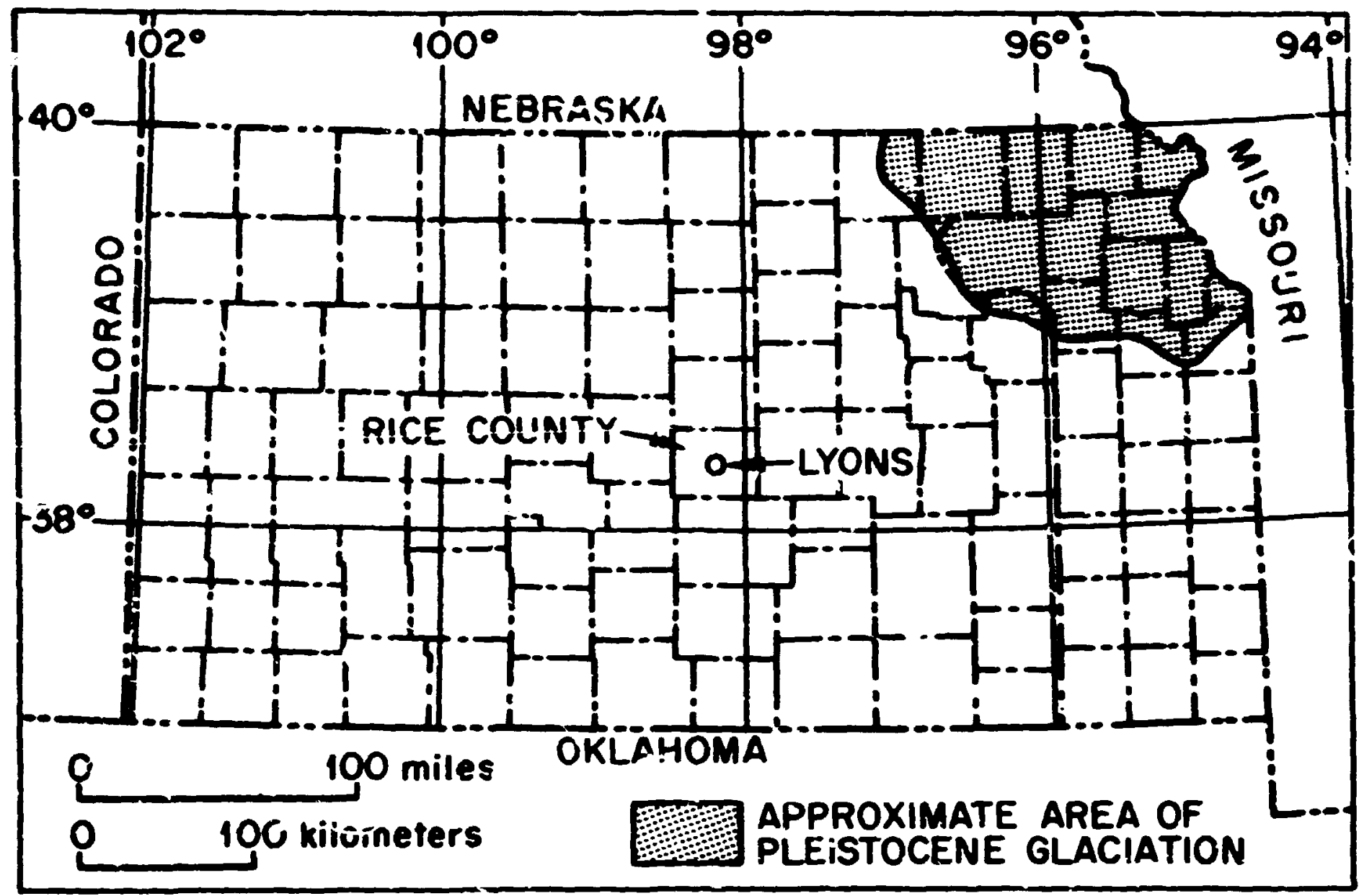

Fig. 2.5. Location of Lyons, Rice County, Kansas, in Relation to Glaciated Area of Kansas. (According to D. E. Zelier, Kansas Geolcgical Survey Bulletin 189, p. 61)

ORNL-DWG 72-10664

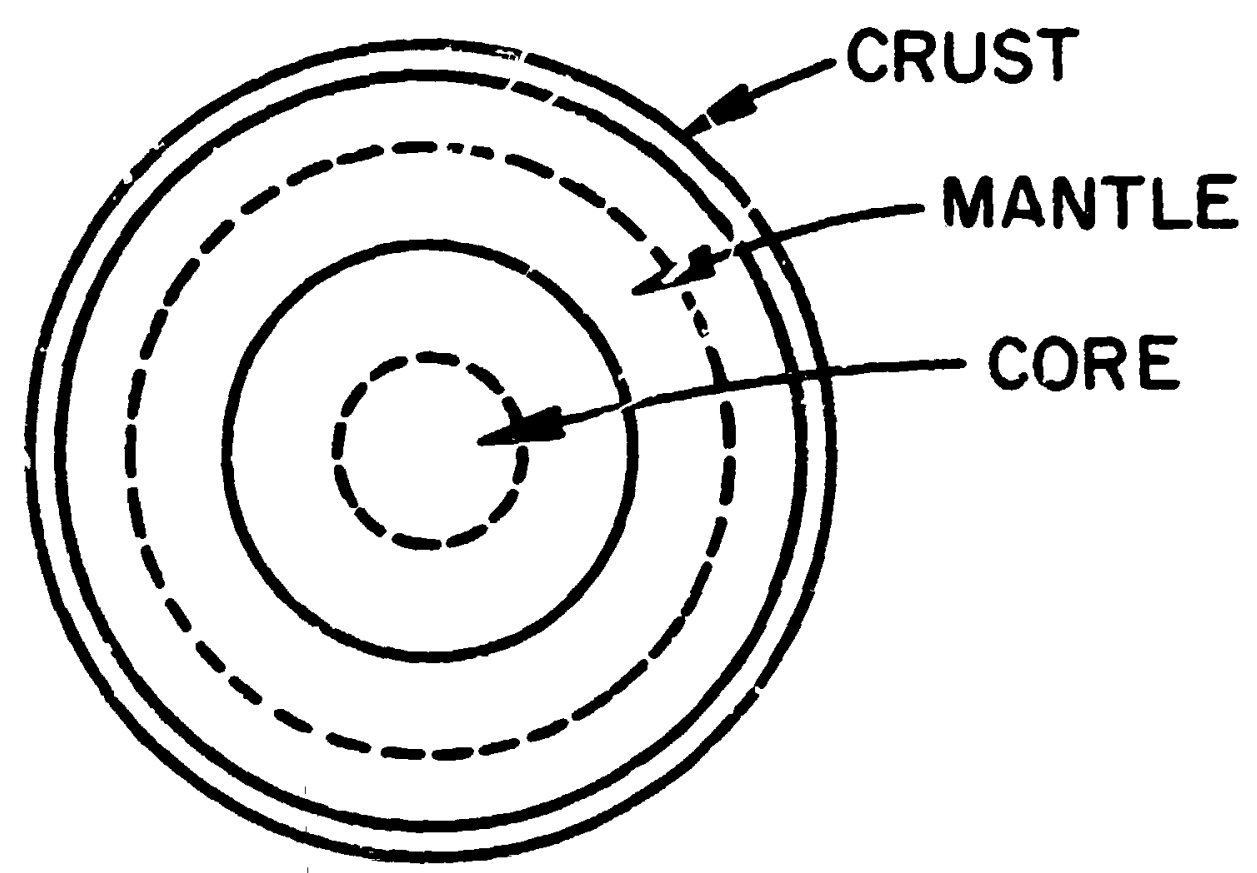

Fig. 2.7. Internel Structure of the Eurth, Shown Diasrammatically. (From ref. . 4 ) 
(3) induced diapiric movement in the salt,

(4) gentle flexire in the upper part of the basenent and sedimentary bedrock, and

(5) folding and faultiris of shailow bedrock, as caused by ice-push. The followile discussion considers the maximal and minimal cases of deformation.

Depression ce the Crust by Glacial Icj. - The crust of the earth ancloses a dense mantle. The thickners of the crust ranges from about 30 to $70 \mathrm{~km}$ beneath the continents but is less than about $8 \mathrm{~km}$ at some places benesth the o. ean basins. 14,15 In this study the crust is corsidered to be a spherical shell that is uniformly thick, isotropic, a: elastic (see Fig. 2.7). Under slow rates of loading, as in the cases of glariation and sedimentation, the mantle shouid react as a highly viscous liçuid. ${ }^{14,16}$

Continental glac:ers are assumed to persist for periods of time sufficient to allow the crust to be depressed, with an equilibriun state to be $\because$ stablished by isostatic adjustment. This assumption implies a steady-state model, in which isscosity of the mantle is not a factor in calculations of amoints of crustal depression.

Extant continental glaciers, namely those in Greenland and Antarctica, are asjumed to be similar to continental glaciers of the Pleistocene. Accordingly, the cross-sectional profile of these former continental glaciers shculd have ieen approximately parabolic. ${ }^{17,18}$ Kaximal thickness of the ice in the central parts of the glaci.rs is assumed to have been as great as $3000 \mathrm{~m} .19,20$ The location of the thickest part of the Wisconsinan continental glacier wiss in the Hudson Bay area, Canada. 21,22 If a contire.ital glacier comparable in size and extent to the glaciers of the Pleistocene were to develcp within the forthcoming several thousand years, its sentral region presumably woul.1 also be near Hudsor Bay.

Depression of the earth's crust by ice sheets and isostatic uplift in response to unoading has bcen reccgnized. for more than a century. 21,23 Deflection of the crust by ise sheets has been studied in Greenland and Antarctica, where the ice-bedrock contact is depressed below sea level 
at scae places. 18 luch research has been done in Horth America on rebound from loading by ice. 24 Defiection of the crust by water in Pleistocent lakes and in mejern reservoirs has also been describea. $25-27$

Deformation of the crust as related to shape and thickness of ice sheets has been studied by several workers on the basis of nodels. 14,22 Most models assume a continental glacier that would be circular in plan view. The models that are judged by us to be nost realistic consider the cross-sectional fort of the elacier to be parabolic, convex upward.

Loading by glacia ice or by large bodies of water induces regional differential pressure in the crust and in the uppir part of the mantle. According to the generally accepted theory of isostasy, slow florage in the mantle and downard flexure of the crust take place intil equilibrium is estailished. The magnitude of crustal depression is related to the thickness of the ice or water lood. Crustai deflection is generally about 25 to $30 \%$ of the totai thickness of the load, inasmuch as the densities of ice and water are each about one-fourth the density of the mantle. (The relative deasity of the nantle is about $3.37,,^{14}$ whereas the relative density of ice is 0.9. )

Potential deformations of tise crust under axisymetric loads o: glacial ice with parabolic profiles, maximal and central thicknesses of $3000 \mathrm{~m}$, and radil of 50 to $2500 \mathrm{~km}$ are show in Fig. 2.8. The assumption is beld that the central region of the Kansan continental glacier was in about the same location as thi: central region of the Hscorzinan glacier, a short diftance west of Hudson Bay, Canada. 21,22 Therefore. a radius of about $230 \mathrm{ckm}$ approximates the southermmost advancement in Kansas of the Kansan blacier. About $2500 \mathrm{~km}$ approximates tise radius of a continental glacier of which the southern edge would extend to Rice County, Kansas.

On the basis oi Fig. 2.9, a continental glacier of the future as extensive as the Kansan glacier may not depress the crust in Rice County but may cause an elevation in the crust of a fer meters. A glacier that would extend intr Rice County should depyess the crust beneath Rice County almost $50 \mathrm{~m}$ (Fig. 2.8) 


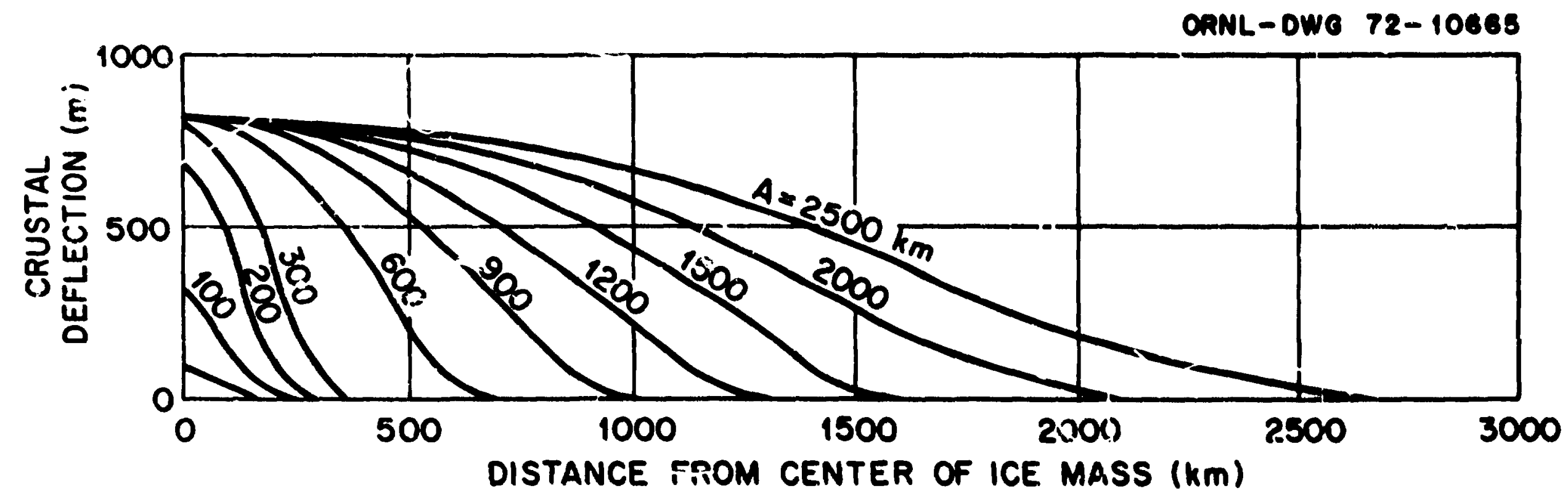

Fig. 2.8, Crustal. Deflections Under Axisymmetric Loada with Parabolic Profiles, Such as Ice Strets with Contral Thicknesses of $30 \mathrm{w}$ m and Variable Radi1. (After flgure given ous p. 5244 of ref. 14) 


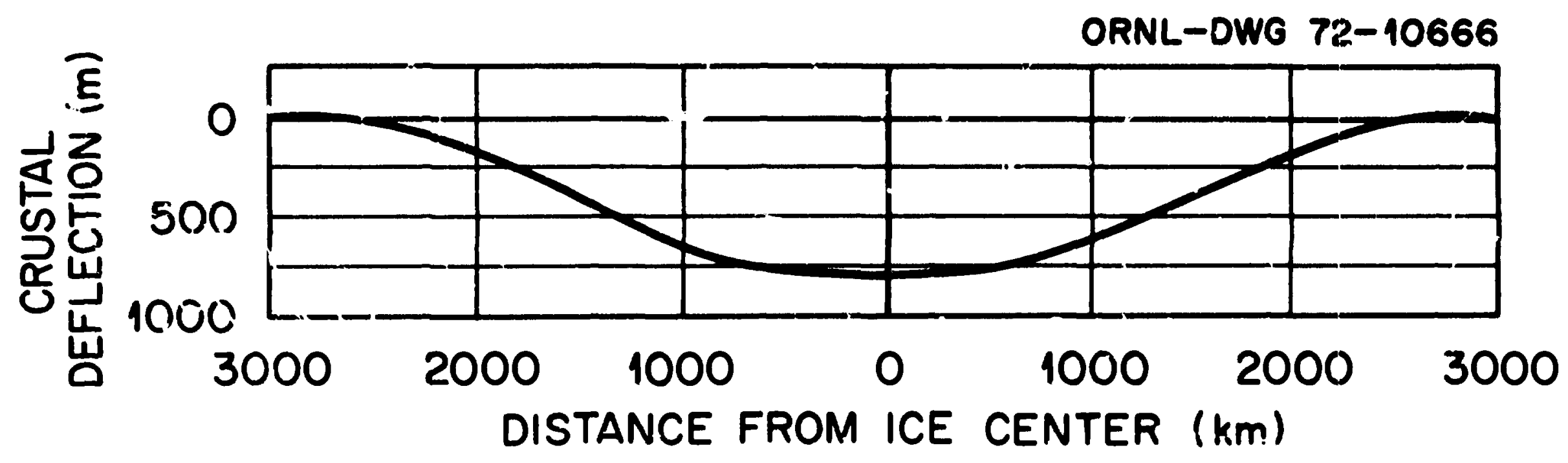

ઈ

Fig. 2.9. Crustal Deflection Beneath an Ice Sheet with a Central Thicknass of $3000 \mathrm{~m}$ and a Radius of $2500 \mathrm{~km}$. Vertical exaggeration, 2000X. (From data 1in Fig. 2.8) 
Probable Stresses in the Crust from Ice Loading. - A continentsl glacier that is basically circular in plan and parabolic in cross section should produce essentially three kinds of stress in the crust:

(1) Vertical and horizontal compression under the ice.

(z) Horizcntal tersion near the margin of the ice sheet.

(3) Shear stress near the margin of the ice sheet.

Table 2.j shows preäsctions made by Brotchie and Silvester for stresses and deflecticns thet could be produced at the surface of the crust by the load of a cuntinental glacier $3000 \mathrm{~m}$ thick in its central region and having a radius of about $I 450 \mathrm{~km}$. The values shown in this table for stresses near the glacier's perimeter are considered to be an approximation of stresses that might be present near the margin of a glacier that would reach into central Kansas. These values should be conservative approximations (i.e., sligitly overestimated); a glacier with a radius cf $1^{1}+50 \mathrm{~km}$ would, of course, be a more concentrated load than a glacier with a radius of $2500 \mathrm{~km}$, extending jnto Kansas.

As discussed above, the crust would deform unaer a load of ice $3000 \mathrm{~m}$ thick in the central part until the amount of displaced mantle equaled the weight of the ice. This deformation of the elastic crust would create compressive, tensional, and shearing stresses within the crust. Table 2.3 shows the magnitudes of the radial and tangential stresses, which would be orthogonal. Radial stresses rould be directed outward from the center of the glacier. As shown in Fig. 2.10, the horizontal stresses would be compressive under the main body of ice anc tensional in a "bulge" near the margin of the glacier that would extend from about $1200 \mathrm{~km}$ to about $1650 \mathrm{~km}$ from the center of the glacier. Shear stress would be near zero under the main body of ice but wculd be comparatively large near the margin of the ice sheet.

Application of Brotchie and Silvester's information directly to the Lyons area should include consideration of the veneer of sedimentary rocks ihat overlie basement rocks. A conservative approximation of the upper 1:mits of stress in the sedimentary strata in the resion near the ice maagin can be sade if the stresses shown in Table 2.3 and Fig. 2.10 are 
Table 2.3. Defloctions and Streaves in the Crust Boneath an Ica gheot of Parabollc Pro:1:0, Central Dapth $3000 \mathrm{~m}$, and Radlus $1450 \mathrm{~km}$

\begin{tabular}{|c|c|c|c|c|c|c|c|c|c|c|}
\hline $\begin{array}{l}\text { D1s:unce rrom } \\
\text { center, } \mathrm{km}\end{array}$ & 0 & 290 & 580 & 870 & 1160 & 1450 & 1500 & 1600 & 1700 & 1800 \\
\hline Derlection, m & 801.93 & 769.12 & 673.00 & 512.76 & 288.06 & 22.60 & 3.74 & -3.86 & -1.07 & 0.11 \\
\hline $\begin{array}{l}\text { Ratial stress, } \\
\text { N } m^{-2} \times 10^{-3}\end{array}$ & -1627 & -1479 & -1503 & -2483 & -1928 & 10,300 & 788.3 & 1232 & -402 & -180 \\
\hline $\begin{array}{l}\text { Tangential stress, } \\
\mathbb{N} \mathrm{m}^{-0} \times 10^{-0}\end{array}$ & -1627 & -1495 & 1300 & -1495 & -1620 & 1486 & 1326 & 263 & -59 & -33 \\
\hline $\begin{array}{l}\text { Shear atress, } \\
N m^{-9} \times 10^{-3}\end{array}$ & 0 & .16 & 9 & 3 & -32 & 104 & -684 & -356 & -14 & 26 \\
\hline
\end{tabular}

Date taken from J. F. Brotchle and R. 811vester, "On Cryatel Flexure," J. Geophye. Ree. "L4(22), $5240-52$ (2969). 


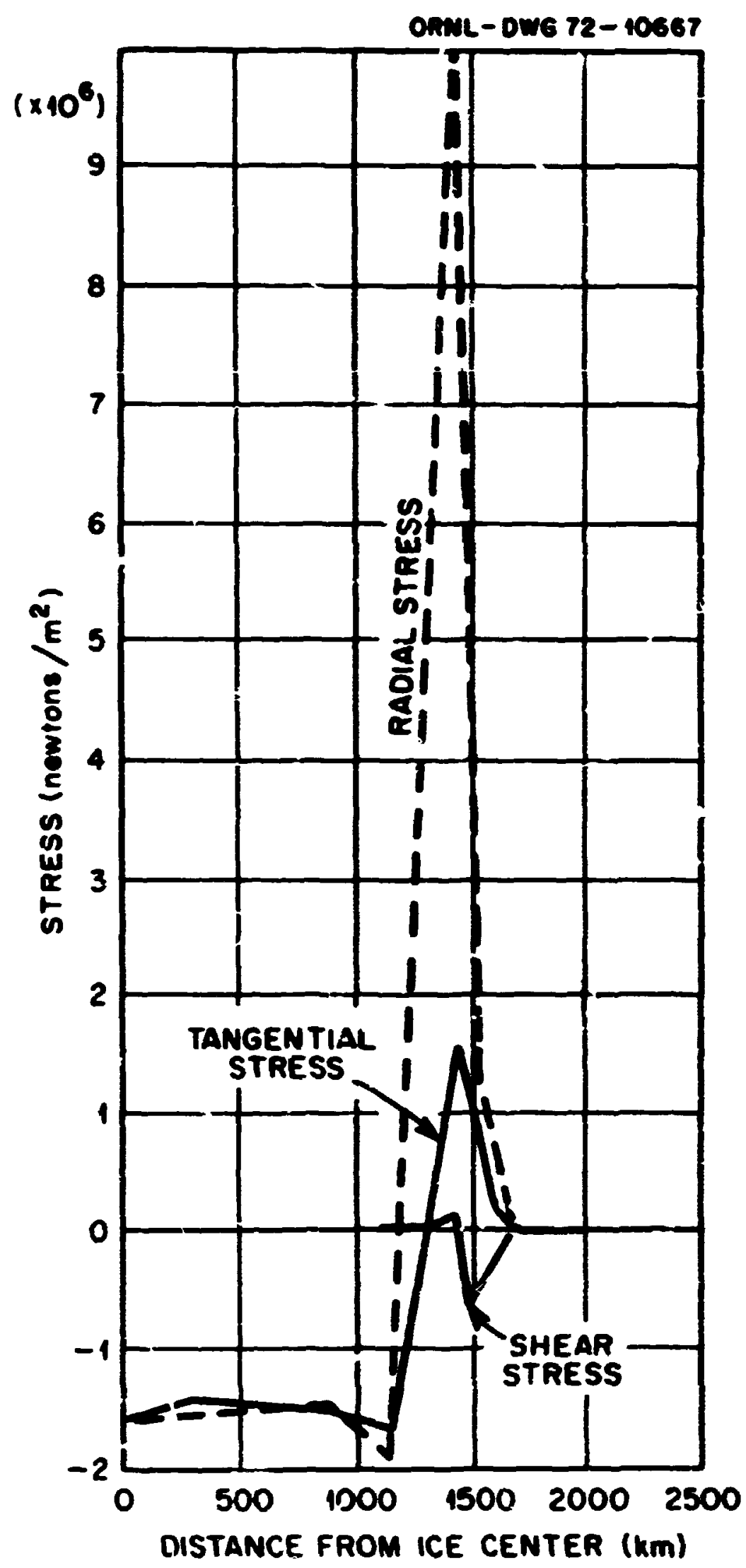

Fig. 2.10. Magnitudes of Stregses Produced at the Surface of the Nonsedimentary Crustal Rocks by an Ice Sheet with Maximal Thickness of $3000 \mathrm{~m}$, Parabolic Profile, and Radius of $1450 \mathrm{~km}$. Maximal stresses should occur within a bulge near the margin of the glacier. Negative and positive stresses danote compression and tension, respectively. (From data in ref. 14 and Table 2.3) 


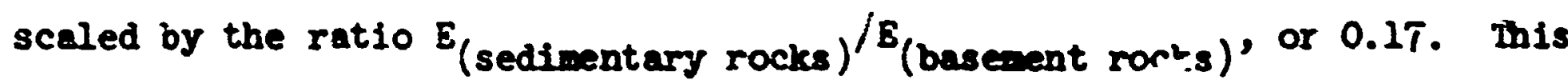
results in maximal copressional, tensional, and shearing stresses of $0.34 \times 10^{5} \mathrm{~N} / \mathrm{m}^{2}$ ( $\left.50 \mathrm{psi}\right), 1.75 \times 10^{6} \mathrm{~N} / \mathrm{m}^{2}$ (-255 $\left.\mathrm{asi}\right)$, aud $12 \times 10^{4} \mathrm{~N} / \mathrm{m}^{2}$ ( -17 psi).

Probable Effects of Stress on Rocks Atove the proposed Repository. The lover limit of structural stablilty of bedruck above the repository site could be approximated on the basis af these prenises:

(1) If fracture of rocks at the repository should occur, it would probably be the result of tensional siress in rocks above the salt strata and within the arginal bulge. Tensional stresses are the largest of the computed stresses, and teosional fracture should occur at shallow depths were confining pressures are smail.

(2) Silty shale is the most abundant zoct type in the stratigraphic: colum at Iyons, Kansas.

(3) Shale should be the weakest rock in the stratigraphic columen, and therefore shoulz be the first to fracture, if fracturing vere to occur as sus gested under (1) above.

(4) Strata above the salt-bearing strate are about $800 \mathrm{ft}$ thick, and thus should be subject to confining pressures ranging from about 1 bar to abcut 55 bars. 28

(5) App:oximation of the strengths of Perwian shale in tise subsurface abore the propcied repository $\mathrm{car}_{1}$ be wade by reference to measurements of strengths of shale by triaxial testing, as oescribed belor.

Shale from the Green River formation (Eocene, Colorado) and from the "5900-Foot Sends Shale" (Pennsylvanian, northern Texas) deformed dry, at room remperatures, under triaxial compression, showed the following ranges of values of strengths (estimated from ref. 28): 


\begin{tabular}{|c|c|c|c|}
\hline & $\begin{array}{l}\text { Confining } \\
\text { Pressure } \\
\text { (bars) } \\
\end{array}$ & $\begin{array}{c}\text { Depth Approxinating } \\
\text { Conrining Pressure } \\
\text { (ft) }\end{array}$ & $\begin{array}{l}\text { Untinte } \\
\text { Strength } \\
\text { (epprodinte) }\end{array}$ \\
\hline $\begin{array}{l}\text { Green forver } \\
\text { Shale }\end{array}$ & 0 & 0 & $620 \mathrm{~kg} / \mathrm{cm}^{2}(8800 \mathrm{psi})$ \\
\hline $\begin{array}{l}\text { Green River } \\
\text { sinale }\end{array}$ & 50 & 750 & $\underset{p=1)}{750} \mathrm{~kg} / \mathrm{cm}^{2}\left(10.7 \times 10^{3}\right.$ \\
\hline $\begin{array}{l}\text { "5300-Poot } \\
\text { sends sisle" }\end{array}$ & 0 & 0 & $\begin{array}{l}750 \mathrm{~kg} / \mathrm{c}^{2}\left(10.7 \times 10^{3}\right. \\
\mathrm{psi})\end{array}$ \\
\hline $\begin{array}{l}\text { "5900-Poost } \\
\text { Sands Sanle" }\end{array}$ & 50 & 750 & 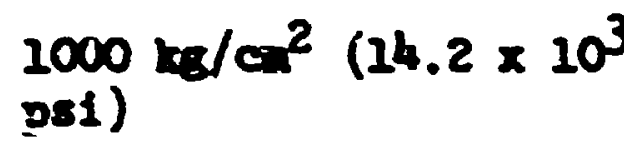 \\
\hline
\end{tabular}

If shear strength is taken as ope-half the differential stress that corresponds with ultinate strength, 28 then the ainimal sivear streigths of the Green River shale and the "5300-Poot Fands shale" should be about $4000 \mathrm{psi}$ and $5000 \mathrm{psi}$ respectivel.y. If tensile strength were to be set1mated at about $4 \%$ of breaking atrength (as susgested by $14138^{29}$ and Blilings ${ }^{30}$ ), then tensile strengths of the Green Biver and "5900-Foot Bands Shale" should be about 350 and 400 pal, reopectively, near the surface and about 400 and 550 psi at depths of about $750 \mathrm{ft}$.

The Green River shale is anch yourzer than the "5900-Foot Sends Shale"; yet, the values of the strengthe ars not maricedry dtfrerent. Although it is recognized that the values shown abore are by no means parasecric in the statistical sense, the simlarity of strengths of two shales greatly different in age suggests the prealse that atrengths of the "5900-Foot Sends Shale" could approxdmate strengths of Peraiden shale in the bedrock at the proposed repository. On the basis of this predise, predicted stresses in shallow bedrock che to glacial loading and approximate strengths of the bedrock ccipare as follows:

\begin{tabular}{|c|c|c|c|}
\hline & $\begin{array}{c}\text { Vertical } \\
\text { Esepressional }\end{array}$ & Shear & $\begin{array}{l}\text { Horticontal, } \\
\text { Tensional, and } \\
\text { Co-pres ionai }\end{array}$ \\
\hline $\begin{array}{l}\text { Estimated strei38 } \\
\text { (maximal), ps: }\end{array}$ & 50 & 17 & 255 \\
\hline $\begin{array}{l}\text { Estimated strength } \\
\text { (near-surface), psi }\end{array}$ & 10,000 & 5000 & 400 \\
\hline $\begin{array}{l}\text { Estimated strersth } \\
\left.\text { (near } 750 \mathrm{ft}^{*}\right), \mathrm{p} 81\end{array}$ & $14,0.00$ & 7000 & 550 \\
\hline
\end{tabular}


2a the basis of the date show above, the conclusion can be derived that stresses unich would be introduced into the veneer of sedimentary rocks by an ice sheet located near the regository do not seem to be large encugh to canse frecturing, except perhaps in the instance of tensional stresses introduced near the surface.

Seeningly, the extrene circunstances would occur if the margin of a costinental glacier vere to ndrance to a position near Lyons, Kansas. The sepository vould then be located uthin the helt of marinel atresses where, according to the aproxiantious above, frecturing dive to horizontal stresses might be possible near the surface but probably not at depths of about 700 to $800 \mathrm{ft}$. Hoverer, two qualiflcations should be montioned.

1. The estiavtes of the tensile strength and the performance of ahaie do bot take lite consideration the effect of a slow builidup of stress. Application of stress to shale over lang intervals of tine might lead to moderate adjustment of the near-surface bedrock without the creation of new fractures. Estimation of rates of loading that aight be expected can be ade by reference to Pleistocene glscial history.

The approxinate durations of the four glaciaticas of the Plefstocene seen to have been as follars: Lebraskan, 250,000 years; $\operatorname{Kensan}, 500,000$ years; Illinoian, 200,000 years; and Hisconsinan, 120,000 years, ${ }^{31}$ AssunIng that the wean zate of advancement of the continental glaciers was abcut 100 a per year, $32-35$ that the Kmsan and Illinoian glaciations approximte the maxial and infinal curations of any future glaciations, and that the wean rates of retreat of the continental glaciers were about equal to the mean rates of advancenent, then a continentsl glacier could advance to Rice County, Kansas, Fithin about 30,000 years after the onset of a glacial episode and could overlie the terrain for as short a time as 60,000 to 70,00 years or as long as 470,000 years. Assuming that the terrain of the proprsed repository would begin to be affected when a glacier approsched withir about $400 \mathrm{~km}$, the time lapse from the inception of stress on bedrock at the repositor; to tive sdvancenent: of the

This assimption is based on date given in Table 2 or rof. 14 (p. 5244), which show that stresses introduced by an ice load affect the crust at distances as great as iji in from the ice sheet's margin. 
glacier's margin to a position above the repository should be about 4000 years.

2. Strengths discussed above were determined from rock-mechanics testing, wherein the assumption is held that rock is solid. Of course, the general truth is well known that bedrock near the surface of the earth is jointed. Since joints were observed in cores taken at the repository site, 36,37 the inference can be drawn that small fractures may be abundant in the shalicu bedrock. Therefore, the question exisis as to how strictly the stress-strength relationships above should be interpreted. However, jointing in the shallow rocks should not be regarded as an altogether unfavorable aspect because shallow bedrock might accommodate slowly imosed stresses (discussed above) by munerous minor adjustments along extant fractures. Therefore, it is possible that major fracturing of the shallow bedrock would not occur.

The general hypothesis that stresses introduced into bedrock near the margins of continental glaciers might cause fracturing of shallow bedrock can be tested on the basis of field geological evidence.

If the Kansan glacier had conformed to the assumptions of shape and thickness stated above, if a r.rginal bulge in the crust had existed, and if the horizontal stresses within the bulge had been as great as those indicated hy extrapolation of Brotchie and Silvester's cowputations, then fracturing of the uppermost few hundred feet of bedrock migkit have cecurred in rccicheastern Kansas. If fari.ts of this origin exist, they should be presenit in bedrock at the surface. They might be expected to strike subparallel to the general boundary of the Kansan ice sheet, and to extend for several milis at the surface.

The areal geolcgy of northeestern Kansas has been studied by a large number of geologists and is considered to be reasonably well known. Geologic maps of some parts of northeastern Kansas include areas across which the boundary of the Kansan ice shcer extended. $38-41$ In this refion, foults or :olds attributed to glaciati. a are few; they extend only $\varepsilon$ few tens of feet into the bedrock and only a few hundreis of feat horizontally. 42 
Consiciering the state of knowiedge of the areal geology of northeastern Kansas, it seems rislid to infer that (1) faults caused by Kansan ice in the uppermost few hundre feet of bedrock do not exist, or ( 2 ) faults of this kind are minor and are so few and so local as to have gone unrecog.lized, or (3) major faults exis ${ }^{+}$but have not been discovered by geologists who have studied the terrain. Of these hypotheses, the nonexistence of "deep" faults caused by the Kansan ice sheet is considered by us to ive the most likely to be true; the existence cf undiscrivered major faults owing to glaciation is considered to be the least likely to be true.

Near the borders of the Illinoian ice sheet on Long Island, Cape Cod, Martha's Vineyard, and some other is?ands of southern ivew England, unconsolidated Cretaceous, Miocene, and Pleistocene deposits are extensivel.y folded and faulted. $43-45$ The deformation is superficial since faulting probabiy extends to only about $50 \mathrm{ft}$ below sea level. 43,46 The ice at the glacier's margin was mcre than $400 \mathrm{ft}$ thick. 43 However, within this region, folds that are overturned southward and northward-dipping thrust falts 43 indicate that faulting was caused primarily by ice-push and drag beneath the ice, rather than by fracture of the bedrock due to weight of the ice.

Terrain in southwestern Illinois inapped carefurly by Rubey ${ }^{42}$ was partly iverridden by the Illinoian ice sheet. Little direct evidence of erosion by ice was recorded. 47 fithough the ice front has probably been stationary for at least 800 and possibiy several thousand years, and the areal geology of the region is favorable for detection of recent structural movements, no evidence of a former marginal bulge of Pleistocene faulting or folding was observed. 47

A belt of postglacial faults in eastern New York and southeastern Quebec 48 is suggestive of the lind of faulting that might have developed in regions that bordered ice shests. This is the only such example that we have discovered. The faults occur almost exclusively in shales and slates; they are closely spaced, and occur mostly in planes of cleavage. 48 Vert.ical displacement ranges from only $1 / 4$ to $15 \mathrm{in}$. and is commonly 1 in. or less; howe er, the cumuiative displacement across zones of these faults could be lisige. ${ }^{1} 8$ Seve:al hypotheses were advanced as explanations of 
the faulting, including stresses caused directly by superincumbent ice. However, the authors favor hypotheses involving expansion of the bedrock and preferential faulting in the shale and slate. 48 Inasmuch as the authors did not comment on the extent of faulting into the subsurface, it seems reasonable to infer that the depth of faulting is not known.

ApparentIy, no defirite eviaerce exists to show that glacjation causes extensive folding and "deep" vertical faultirg of competent bedrock near the ice border. However, this presumed lack of evidence is regarded as bejing insufficient to deny the geophysical theory that ice sheets can cause large stresses in crustal rocks within a marginal bulge. However, the paucity of evidence of deformation suggests (1) that stresses near the ice front were commonly not large enough to cause more than superficial fracturing of the shaliow bedrock or ( $\overline{\text { I }) ~ t h a t ~ l a r g e ~ s t r e s s e s ~ w e r e ~}$ imposed slowly and were accommodated by moderate duformation of bedrock without deep faulting.

Probable Ëffects of Ice-Push. - As discussed above, ice-push and icedrag deformed a few hundred feet of Pleistocene, Creta: sous, and Miocene deposits on the islands of southern New England. It should be emphasized, however, that strata were unlithified then disturbed. In the Midcoritinent, faultins and folding of competent Paleozoic rocks caused by ice-push is entirely superficial. Where ice-push deformation has been identified, only a few tens of feet of bedrock are disturbed. 42,49

Prcbable Effects of an Ice Sheet on Salt Strata in Central Kansas. A diagrammatic profile of an ice sheet of radius $2500 \mathrm{~km}$ and theoretical maximal thickness of $3000 \mathrm{~m}$ is shown in Fig. 2.11. The profile is consistent with the basic form of the ice cap on Greenland, which is abor.t $3000 \mathrm{~m}$ thick although much less extensive. 50 The profile also closely resembles a reconstructed cross saction of the marginal Wisconsinan ice sheet in southern Indiana. 51

Figure 2.11 is assumed to approximate the general cross-secticnal form of any ice sheet that might extend into the Midcontinent. On the basis of this assumpiion, the inference can be drawn that, if an ice sheet were to advance $300 \mathrm{~km}$ into Kansas in a south-to-southwesterly 


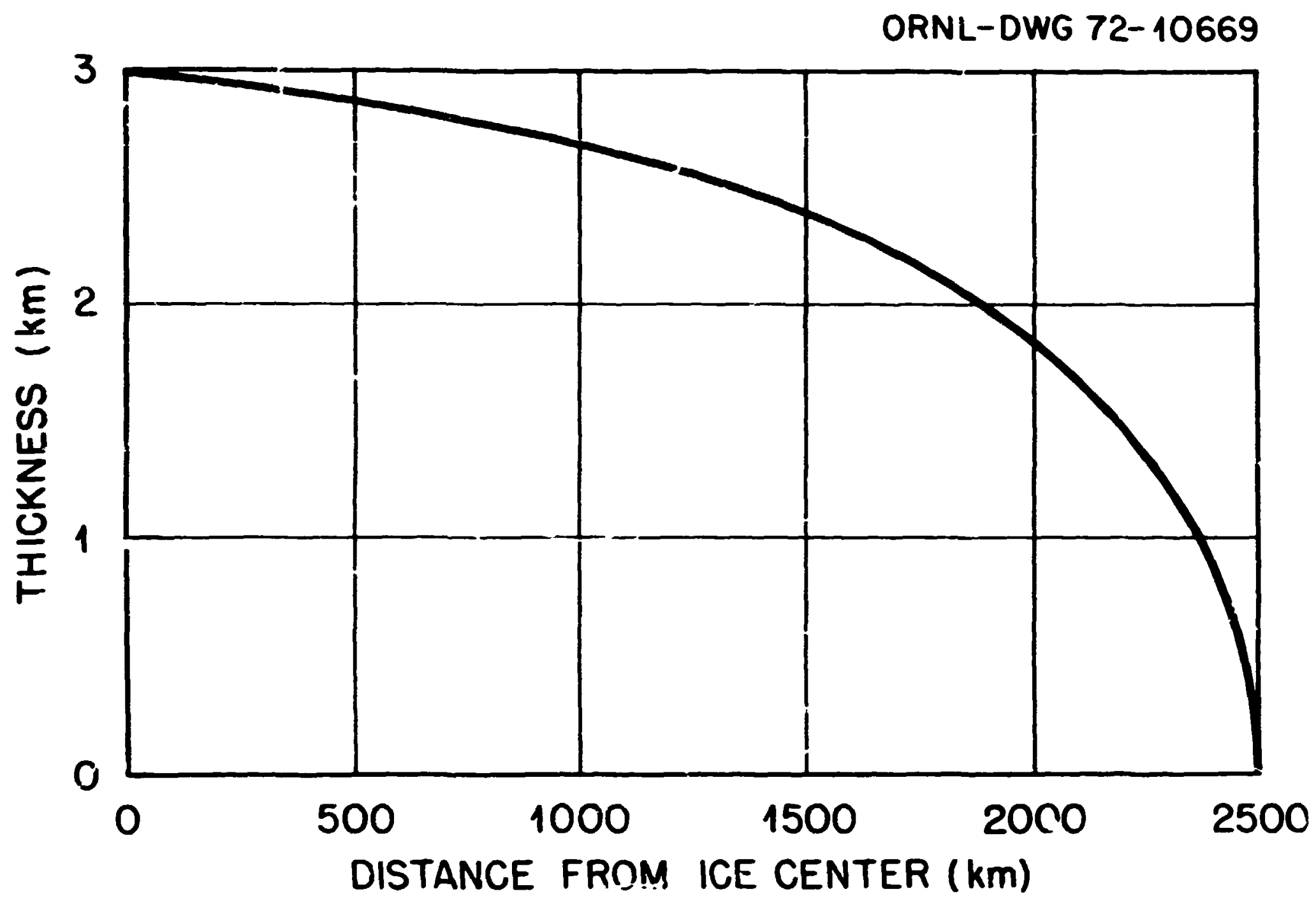

Fig. 2.11. Apprcximate Profile of an Ice Sheet with Maximal Thickness of $3000 \mathrm{~m}$ and Radius of $2500 \mathrm{~km}$, extending from Its Center to Its Margin. Vertical exaggeration, 500X. (Constructed from data in refs. 19, 20, 50, and 51) 
direction, a maximin of abolt $1000 \mathrm{~m}$ of ice should lie above the repository. This amount of ice would be approximately equivalent to a load of sedimentary rock about $300 \mathrm{~m}$ thick. (The relative density of ice is 0.9; the relative density of sedimentary rock is about 2.7.) Therefore, the ice should exert a vertical stress on the order of $1000 \mathrm{psi}$ on the bedrock.

Gera $^{52}$ suggested that the minimal thickness of salt necessary for the initiation of diapirism is 300 to $400 \mathrm{~m}$; salt straia at the repository site are altogether only about $90 \mathrm{~m}$ thick. During the early part of the Tertiary Period, the Permian of central Kansas was overlain by more than $750 \mathrm{~m}$ of Cretaceous rocks. ${ }^{5 j}$ The force of overburden of the complete Cretaceous section was approxinately 2500 psi, a load equivalent to more than $2000 \mathrm{~m}$ of ice. Moreover, the Cretaceous rocks were being eroded subaerially and thus did not impose a uniformly distributed load on the Permian. However, no evidence of diapirism in the salt of central Kansas has been reforted. Nor has evidence of diapirism been reported in the salt deposits of the upper mici-western states or of Alberta and Saskat,chewan, Canada. 54-57 In these regions, salt is thicker at many places than it is in Kansns; aiso, loading of bedrock by ice was greater than loading that could be expected in Kansas.

In general, minimal conditions necessary for the initiation of largescale, shurt-term (geologically speaking) flow of salt seem to be an overburken pressure of about $12,000 \mathrm{psi}$ and temperatures greaier than 200$)^{\circ} \mathrm{c} .53$ Inasmuch as depth of burial of salt in central Kansas is about 800 to 1000 fi, overburden pressure due to bedrock alone should not exceed about 1000 psi and overburden pressure ae to bedrock and glacial ice should not exceed about 2000 psi. Thest stresses are obviously much less than the stress presumed to be required for initiation of large-scale salt flow.

The ambient temperature of the rock salt at the repository site is about $2.1^{\circ} \mathrm{C}$. The maximum temperature within the repository is predicted to be $200^{\circ} \mathrm{C}$, and should occur abcut 50 years after emplacewent of niclear waste. Thereafter, it should decrease rapidly, presumably until it stabilizes near the present temperature. 
The following points can be advanced as evidence to show that salt flow or diapirisu resulting from loading by glacial ice should not occur at the repository.

(1) The rock salt in central Kansas is thinner than the minimal amount presumed to be necessary for diapirisra to occur.

(2) Stress on the salt when loaded by glacial ise would be less than che amount judged to be required for diapiric flow.

(3) The temperature of the salt may approach the threshold for diapiric flow; but, because of the small force of overburden, elevated temperatures should not lead to diapirism of the salt - even if loading by ice and highest temperatures of the repository were to occur simultaneously. (The probability of this has been show to be effectively zero by a foregoing argument.)

Summary and Conclusions. - Three assumptions are held: the late Cenozoic glacial age is still in progress; the present is an interglacial interval; and the probability of another continental glaciation approaches ccrtainty.

Continental ice sheets ciepress the crus's of the earth by flexure and cause isostatic adjustment. An ice sheet that would enter central Kansas should tlex the crustal. : $x^{\prime}$ 's upward by a few meters as it approaches the terrsin containing the repository; in the event that it should override the repository, it would depress the crust by about $50 \mathrm{~m}$. Compressional, tensional, anc. shear stresses would be introduced into the sedimentary rocks. Comparison of stresses estimated to be caused in the bedrock above the repository with estimated strengths of the redrock indicates that an ice sheet's approach to or overwiding of the repository should not cause deep fracturing of the rocks.

Areal geologic evidence from Kansas, southern New England, and Illinois, all of which are regions that were entered by ice sheets $0^{\circ}$ the Pleistocene, indicates that disruption of bedrock by the former ice sheets was only superficial. No faults owing to glaciation are known to extend as deep into the subsurface as the location of the proposed repository, even in scuthern New Ingland, where the ice moved across unlithified 
deposits. Effects of ice-push and ice-drag on bedrock in central Kansas should be negligibie. Stresses intruduced into the bedrock ky glacia? loading should cause no tlow of salt within the repository. 


\subsection{Alternative Site Keconnaissance in Kansas}

The search for alternative sites in the underground salt deposits of Kansas was performed in two stages. F:sst, the available information on eight country-sized areas pertinent to waste disposal was compiled and the areas were assessed for their suitability. The results of this study are given ir. Sect. 2.2.1. Then, using the information collected in the first study, three specific potential sites wexe identified and further investigated. This work included field reconnaissance and the drilling and testing of one core hole at each potential site (Sect. 2.2.2).

\subsubsection{Screening Survey}

In December 1971, the State Geological Survey of Kansas prepared a report on eight county-sized areas that were considered potentially suitable for the storage of high-level radioactive wastes. These areas, shown in Fig. 2.12, were select.ed on the basis of the general knowledge of each area, the presence of at least $150 \mathrm{ft}$ of salt at a depth of less than $2000 \mathrm{ft}$, and a minimum of oil and gas development. For each of these areas, the following uypes of dsta were compiled: (1) geology and hydrology; (z) population centers and densities, transportation facilities, and other cultural features; (j) locations and status of oil and gas wells, as ireli as an estimate of the fotential for future petroleum exploration; and (4) the characteristics of the salt formation as inferred from electric logs. The information collected for the report was obtained only from readily available sources, both published and unpublished file data; no field work or other investigations to generate originsl information were undertaken. It was compiled in "Preliminary Geological Investigations of Supplemental Radioactive Waste Repository Areas in the Statt of Kansas," edited by E. F. Angino, C. K. Bayne, and J. C. Halepaska. An abridged version of tilis report was subsequen:ly published as Kansas Geological Survey Special If:tribution Fublication No. 60 under the title "Supplemental Areas for Storage of Radioactive Wastes in Kansas," compiled by C. K. Bayne. The descriptiors of the eight study areas in the following sections were taken from these reports, 


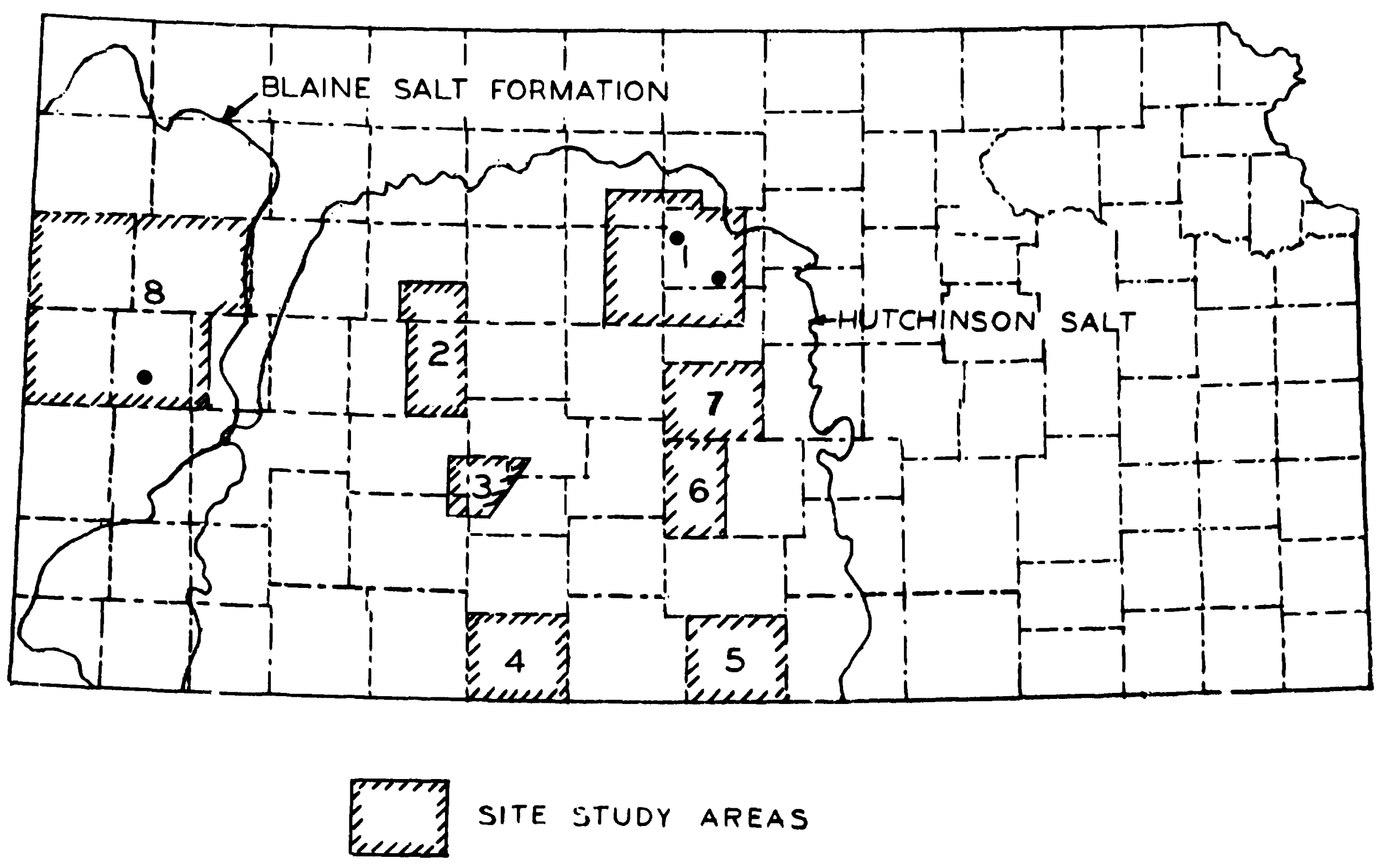

Fig. 2.12. Map of Kansas, Showing the Eight Areas Involved in Site Screening Studies. 
Area 1. - Area I (Fig. 2.12) includes parts of Ellsworth, Lincoln, Mitchell, Osborne, and Russell counties in central Kansas in an area $\rightarrow$ rained by the Smoky Hill River and tine Saline River. Structirally the area lies in the Salina basin, just east of the Cen'ral Kansas Uplift.

Geology and Hydrology. - About 500 ft of rock consisting principally of shale but also containing dolomite, anhydrite, and gypsum is present above the Hutchinson salt member of the Wellington formation and below the Stone Corral formation. The lower $250 \mathrm{ft}$, which belongs to the Wellington formation, is primarily gray and blue-gray shale but contains some red shale in the upper part. The upper $250 \mathrm{ft}$, which comprises the Ninnescah shale, is primarily red shale but contains some gray shale. Neither the Wellington nor the Ninnescah contains water in this area.

The Stone Corral formation overlies the Ninnescah shale and is comprised of about 20 to $25 \mathrm{ft}$ of dolomite, anhydrite, and gypsum. Anhydrite and gypsum are the dominant components. Little, if any, water can be obtained from this unit.

The Harper sandstone overlies the Stone Correl formation in this area. The Farper, wich consists principally of red, siity shale and contains little sandstone, will yield little or no water to wells. The upper surface of the jarper is an erosjonal surface and marks the boundary between Permian and Cretaceous rocks in the area.

The Cheyenne sandstone is the lowermost Cretacecus unit present in Kansas. In Area $I$ the Cheyenne does not crop out and is present in the subsurface only in the westermost part. In much of Area 1 the Cheyenne consists of a very fine, silty sand and is not an important aquifer; however, west of this area (and probably localiy in Area 1), it contains large quantities of sand, and moderate quantities of highly mineralized water should be available.

The oldest rock unit that crups out in this area is the Kiowa formation. This unit conformably overlies the Cheyenne sandstone where the Cheyenne is present and unconformably overlies Permisn rocks where it overlaps the Cheyenne. The Klowa consists primarily of dark-gray and brownish shale but also contains thin to massive sandstone beds, thin shell beds, and 
lignite. In the soutilern part of the area, a full section of the Kiowa, if present, is about $150 \mathrm{ft}$ thick. The unit thins toward the north and may be less than $100 \mathrm{ft}$ thick in Nitchell and Osborne counties. Sandstone beds in the Kiowa are more common in the southern part of the area. Here yields of water as large as $100 \mathrm{gpm}$ may locally be available to wells. Toward tine north and west, where the Kiowa thins and sandstone beds are les 3 common or absent, little or no water is availeble.

The Dakota formation overlies the Kiowa formation. The Dakota is composed of clay, shale, sandstone, and (locally) some lignite. Lightgray, dark-gray, and red shale comprises about two-thirds of the total thickness of the unit, which is about $250 \mathrm{ft}$. Sandstone beds occur throughout the unit. The Dakota is the principal aquifer in this area. Yields of wells may locally be as much as $250 \mathrm{gmm}$ but more commonly are less than $50 \mathrm{gpm}$. In Ellsworth County and soutkern Lincoln County, the water from the Dakota is of gool quality; however, it may be too highly mineralized for use in Osborne, Mitchell, and Russell counties.

Cretaceous rocks that overlie the Dakota formation in Area 1 are, in ascending order, the Graneros shale, the Greenhorm limestone, and the Carlile shale. The Graneros is a dark-gray, clayey to platy shale which weathers to a brownish color. The thickness of the unit ranges from about 25 to $35 \mathrm{ft}$ in Area 1. The Greenhorn limestone is composed of about 70 to $90 \mathrm{ft}$ of thin, chalky limestone beds interbedded with thicker, chalky shale. These limestone ieds range in thickness from a fraction of ai. inch to about $10 \mathrm{in.}$ The thickest and most prominent bed is the "Fencepost limestone," which occurs at the top of the Greenhorn. The Carlile shale is composed primarily of chalky shale but contains thin beds of nodular, chalky limestone in the lower part. Thin beds or seams of bentonite occur throughout the Graneros, Greenhorn, and Carlile in this area. None of these units is a good aquifer. Only small quantities of water are available from the upper weathered parts of the inits.

Alluvial deposits that occur in the valleys of the Smoky Hill River and the Saline River and in the abandoned Wilson Valley, which extends from the Saline River near ncrthwest Ellsworth County southeastward to the Smoky Hij.l River (a few miles west of the city of Ellsworth), are arkosic-type materials indirating a western source. These deposits are 
generally little more than $50 \mathrm{ft}$ thick. Water yields are near $250 \mathrm{gmm}$ ai the maximum but are more cammonly ifs. than $100 \mathrm{gpm}$. The allurial r.eposits in the abandoned Wilson Valley are somewhat thicker; hc:ever, these deposits occur in a channel cut in an upland area which has been beheadr:a at both ends by more recent erosion or downextting of the streams. The channel is largely drained of ter and yields oniy small quantities.

Population and Transportation. - Cities within Area 1 are mostly lonsted in or near the valleys of the principal streams. Railroads built in the area were located in the valley areas to avoid steep grades, ana cities grew along the railroads. The main line of the Union Pacific Railroad crosses EIIsworth and Russell counties in the southern part of $t^{2}$ se area, end a branch line of the Union Pacific Railroad serves the northern part of tre area in the valleys of the Saline River ard Wolf Creek. Interstate Highway 70 and State Highways 4 and 18 traverse the area from east to west. State Highrays 14, 181, and 2.32 are north-south thoroughfares through the area.

Oil and Gas. - A few wells producing small amounts of oil and gas have been drilled in the southern part of Area 1. The most recent discovery is the Wilson gas field, which is located north of the city of Wilson in northwestern Ellsworth County. Several areas of township size in the northern part of the area contain no drilled holes. Much of Area 1 lies in the western part of the Saline Basin, an area not considered to br promising for future developmert of oil and gas.

Ssit. - The Hutchinson sali cccurs in Area 1 at depths ranging from about $600 \mathrm{ft}$ in the southeast to about $1200 \mathrm{ft}$ in the northwest. Nearly $300 \mathrm{ft}$ of salt is present in the west-central portion of the area. The salt, thins toward the east and north. Salt in about one-third of the total area is near or less than the minimum required thickness of approximately $150 \mathrm{ft}$.

Area 2. - Area 2 (Fig. 2.12) includes part of southeastern Trego County and eastern Ness County. The northem part of the area is arained by the Smoky Hill River; the southern part is drained by Walnut Creek. Structurally the area lies on the west flank of the Central Kansas Uplift. 
Fenlogy and Hydrology. - The geological features of this area are sirilar to those in Area 1. The Hutchinson salt member is overlain by the hellington and Ninrescah shale. The upper Wellington is comosed of about $200 \mathrm{ft}$ of gray and blue-gray shale. Some thin anhydrite and dolomite beds are also present. The Ninnescan shale is cymprised of about $200 \mathrm{ft}$ of predominantly red shale; however, some grey shale is present. The Wellington and Ninnescah incluae no permeable units and contain little, if any, water in this area,

The Stone Corral formation, which overlies the Ninnescah shale, is composed of about $25 \mathrm{ft}$ or anhydrite an! probably some gypsum. Permeability has not been deveioped in these rocks; and a negligible amount, if any, of water is present in the formation.

The Harper sandstone overlyng the Stone Corral is composed principally of red siltstone and shale in this area. The unit is about $150 \mathrm{ft}$ thick and contains little sandstone. It is not an important aquifer.

Iower Permian rocks between the Harper sandstone and the Blaine formation, consisting of the Salt Plain formatior, tha Cedar Hills sandstone, and the Plower-pot shale, have an aggregate thickness of about $500 \mathrm{ft}$ in Area 2. Moderate to large quantities of highly mineralized water are available from these rociss.

The Blaine formation is present only in the southe:n part of Area 2, where it is about 15 to $20 \mathrm{ft}$ thick.

Lower Permian rocks consisting of the Dog Creek formation and the Upper Permian Whilehorse formation are present in the southern part of the area but are abser: in the northern part where they were probably removed by pre-Cretaceous erosion. Small to moderate quantities of water are probably available in local areas from sandstone in the thitehorse.

Lower Cretaceous rocks consisting of the Cheyenne sandstone, Kiowa formation, and the Dakota formation are present in the area and unconformably overlie Permian rocks. They have an aggregate thickness of about $500 \mathrm{ft}$. The Kiowa is quite thin and contains little, if any, sandstone. 
Moderate to large quantities of highly mineralized water are available from the Cheyenne, and yields of up to $300 \mathrm{gpm}$ of good-quality water have been obtained from welis in the Dakota.

Upper Cretaceous rocks consisting of the Graneros shale, Greenhorn limestone, Carlile shale, and the Niobrara chalk, with an aggregate thickness of about $450 \mathrm{ft}$, crop out in Area 2. Little, if any, water is avajlable from the Upper Cretaceous rocks in this area.

Thin deposits of silt, ciay, sand, and gravel comprising part of the Ogallala formation of Pliocene age bre present on the highest uplands in Area 2. Srall quantities of water are locally available from these deposits.

Alluvial deposits of Pleistocene and Recent age are present in the velleys of the Smoky Hill River End Walnut Creek. Yields of wells in these deposits in the Smoky Hill Valley may be as much as $500 \mathrm{gpm}$ in local areas. In the Walnut Creek Valley, yields of wells generally do not exceed 50 gpm; however, lcrally as much as 200 gpn may be obtained.

Population and Transportation. - Population centers in the southein part of Area 2 are located along a branch line of the Atchison, Topeka, and Santa Fe Railroad in the Walnut Creek Valley and in the northern part of Ness County along a branch line of the Missouri Pacific Railroad.

State Highways 4 and 96 cross the area in en east-west direction, and U.S. Highway 283 runs north-south along the west side of the area.

Oil and Gas. - There is a highly developed area of oil and gas production in the eastern part of Area 2. The western part of Area 2 has had less development, although scattered fields with one or two wells each are present. Area 2 is currently (1971) quite active and vill probably continue to be so in the future. It is socated on the western flank of the Central Kansas Uplift, and oil and gas are produced from swail structural and stratigraphic traps on the truncated Mississippiar. surface.

Salt. - In area 2 the Hutchinson salt occurs at depths ranging from about $1800 \mathrm{ft}$ in the southeast to about 2:00 ft in the northeast. The depth to the top of the salt is greater than $2000 \mathrm{ft}$ in about one-half of the area. The thickness of the salt ranges from about $150 \mathrm{ft}$ in the 
northeast to about $300 \mathrm{ft}$, in the souvh. The thickness throughcut essentially the entire area is greater than $150 \mathrm{ft}$. The quality of tre salt is judgel to be lower than that of the Lyons repository site or of Area 1.

Area 3. - Area 3 (Fig. 2.12) includes paris of Pawnee, Euraras, Hodgeman, and Ford counties. The northwestern part of the area is drained by tributaries of the Pawnee River; the remainder is drained by the Arkansas River. Structurally the area lies on the western flank of the Central Karisas Up'ift.

Geology and Hydrology. - The upper part of the Wellington formation and the Kinnescah shale sre present between the rutchinson sait and the Stone Corral formation. In the northern part of Area 3 the combired thickness of these rock units is about $400 \mathrm{ft}$; in the southern part it is about $500 \mathrm{ft}$.

The Stone Corra] formation orerlies the Binnescah shile. This unit, about 25 to $30 \mathrm{ft}$ thick, is composed principally of anhyurite in Area 3 .

The Harper sandstone, the Selt Plain formation, the Cedar Mills sandstone, and the Flower-pot shale, with an aggregete thickness of about $630 \mathrm{ft}$, s.re present between the Stone Corral and the Blaine formations. Moderate to large quantities of high/y mineralizsd water are avallable from this seciion of rocks in Area 3.

The Blaine formation, composed principally of gypsum and about $20 \mathrm{ft}$ thick, is orerlain by abo.t 250 f't of silty shaie and dolomite. Little sandstone is present in these rocks in tiris area, and only small quantities of water are available.

About 400 to $450 \mathrm{ft}$ of Lower Cretaceous rcirs composed of the Cheyeme sandstone, Kiowa formation, and the Dakota foriution unconformably orerlies the Upper Permian rocks in Area 3. Much of the Cheye.zre is comprised of sandstone, and moderate to large quantities of highly mineralized water are available from the unit in this area. The Kiowa formatiun is not an important aquifer. The Dakota formation, which crops out in a sma?.1 area in the northwestern part of Area 3, is composed principally of ciay, shale, and sandstone. A fex miles west of the western border of Area $j$, the 
sandstone in the Dakota thickons and is very permeable. As much as 1000 gpm of good-quality water can be obtained from wells in this area. Eastward the sandstone thins and is less permeable, and vields of wells are considerably smaller; however, yields of 200 to $300 \mathrm{gpm}$ can be obtained locally.

The Upper Cretaceous Graneros shale and Greentorn limesione crop out in the northwestern part of Area 3. These units are composed of shale, chalky shale, and chalky limestone and yield little or no water to rells.

Thin deposits of sand, gravel, silt, anc clay, which comprise a part of the Ogallala formation of Pliocene age, are present in the northern part of tinis area. These deposits yield small to moderate quantities of water to well.s in local areas.

Pleistocene deposits underlie most of the land surface of Area 3. Older rocks occur at the surface only in the northern and northwestern parts of the area. In the uplands west of the Arkansas River Valley the surface is imediately underlain by loess. The loess overlies older Pleistocene silt, ciay, and, locally, sand and gravil. Sma'l to moderate quantities of water are available lcially in this area. Alluvial deposits in the Arkansas River Valley comoriy yi ld as much as 1000 gpm to well.3. Fopulation and Transportation. - Population centers in this area are loceted along the railrosds. Kinsley, the lergest city, with a 1970 population of 2283, is located in the Arkansas River Valley at the junction of the mainifise of the Atchiscn, Topeka, and Santa Fe Railmad and the Great Bend Brancis of the Santa Fe.

U.S. Highray 50 crosses the southern part of the area from east to west; U.S. Highway 56 crosses the area irnm northeast to southwest; and U.S. Highray 183 crosses the area from north to south.

Oil and Gas. - Relatirely swall flelds from which ofl or gas has been produced are found in 211 parts of Area 3. At the present time there is little drilling activity; however, the area is locsted on the west flank of the Central Kansas Uplift, ani the possibility of Pinding o1? in stratigraphic or structural traps on the truncated Mississippian surface will probably generate more interest in the future. 
Salt. - The Iutchinson salt occurs in frea 3 at depths of about $1650 \mathrm{ft}$ in the northeast and about $1950 \mathrm{ft}$ in the western part of the are.?. The salt ranges in thickness from about 350 to $400 \mathrm{ft}$. Its quality is comparable to that found in Area 2.

Area 4. - Aree 4 (Fig. 2.12) includes 211 of Comanche County, which is adjacent to Jklahoma in south-central Kanse.s. The western part of the area is drained by the cimarron Ri-rer and its tributaries. The eestern part of the area is drained by Salt Fork Creek. Structurally the area lies on the northern flank of the Anacarlio Basin in a part of the besin inst has bezen called the Dodge City Erbayment. The area is located west of the Pratt Anticline and soinhwest of the Central Kansas Uplift.

Geology and Hydrology. - In Area 4, the upper part of the Wellington formation and the Ninnescah shale between the Hutchinson salt and the Stone Corral formation have an aggregate thicknt ${ }^{-c}$ of about $800 \mathrm{ft}$. The section of rock between the top of the Ninnescah shale and the top of the Blaine formation, composed of the Stone Corral formation, Harper sandstone, the Salt Plain formation, Cedar Hills sandstone, Flower-pot shale, and the Blaine formation, is about $600 \mathrm{ft}$ thick. 'ine Stone Corral is composed principally of anhydrite in the area; the Blaine formation is preduminantly gypsum. The other rock units in the area are chiefly silty shele or siltstone; however, in local areas mach randstone occur il $_{1}$ the Cedar Hills sandstone. Sandstone is less prominent in the Salt Plain Pormation. Moderate quantities of highly msneralized water are probably available from the sandstone beds.

The Flower-pot shale is the oldest rock unit that crops out in Area 4. The Flower-pot is overlain by the Blaine formation, which is, in turn, overlain by the Dog Creek formation of Lower Permian age and the Whitehorse formation of Upper Fermian age. Salt with occurs just below the Blaine in counties north and west of Area 4 is not present in this area. The Whitehorge has the greatest oreal distribution of the bedrock units in the area. Small exposures of the Big Basin formation occur in the southern part of the area. 
The Lower Cretaceous Cheyenne sandstone and Kiowa fornation urconformably overlie the Whitehorse formation in the northeastern and central parts of Area 4, and locally overlie the Big Basin formation in the scuthern part of the aree. The Cretaceous rocks are overlain by shetilike deposits of sand and gravel of protable eariy Pleistocene age. Only small quantities of water are available from the Cretaceous rocks near the outcrop.

Alluvial deposits of Pleistocrne age which occur in the western and southwestern parts of Area 4 are generally thin. The sheetlike ceposits in the northern part of the area may be as much as $100 \mathrm{ft}$ thick. Wells in this area may yield severil hundred gallons of water per minute locally. Near the outcrop margins the deposits are largely drained and yield only small quantities of water.

Alluvial and low terrace deposits in and adjacent to the principal streams are generally thin and yield only small quantities of water to wells; however, locally, these deposits thicken and may yield severa: hundred gallons per minute.

Dune sands occurring adjacent is streams in the western part of the area and in an upland position in the sentral part of tise area are thin and unimportant as a source of water.

Population and Transportation. - Population centers are located along the Engierwod Brarch of the Atchison, Topeka, and Santa Fe Railroad. Coldwater, with a 1970 population of 1206, is the largest city. U.S. Highway 160 crosses the area in an east-west direction; U.S. Highray 183, a north-south thoroughfare, serves the northem part of the area.

0il and Gas. - Area 4 contains scattered oil and gas fields. Numerous dry holes have been drilled throughout the area; nevertheless, there are several areas in which little or no drilling has been done. Exploration has been quite active in Area 4. Production, which arises from the Pennsylvanian, Mississippian, and Ordovician rocks, is related to structural and stratigraphic traps.

Salt. - The lutchinson salt occurs in Comanche County at a depth rasking from about 1650 to 1800 ft. The thinkness of the fiutchinson salt in this area ranges from approximately $450 \div 0500$ it. The quality of the 
Hutchinson saj.c ir. this area is judged to be poorer than that of the Lyons repository site or of Area 1. It is similar to that of Areas $\hat{c}$ and 3 .

Area 4 is not far distain from areas where solution has occurred in the salt beds. Collapse features, which are believed to be associated with solution of salt along faults, occur in Meade County, to the west. In Clark County, the Big and Little basins are collapse features probably associated with sait dissoivition in a iocai area. These solution features are likely associated with dissolution of the Blaine salt, which occurs about $600 \mathrm{ft}$ above the Stone Corral. There is no known evidence of solution in the Hutchinson and Cimarron salts.

Area 5. - Area 5 includes all of Harper County, which borders Oklahoma in south-ceniral Kansas. This area is drained in the west by Spring Creek and in the east by Bluf: Creek and the Chikaskia River, all of which are tributaries of the Salt Fork River in Oklahoma. Structurally Area 5 lies within the Sedgrick Basin on the east flank of the Pratt Anticline.

Geology and Hydrology. - Although about 250 to $300 \mathrm{ft}$ of the upper part of the Wellington formation is presert between the Futchinson sait and the base of the Hinnescah shale in this area, it contains little, if any, water. The Ninnescah shale is about $400 \mathrm{ft}$ thick in the southern part of the area but thirs torard the north. The upper part of the Ninnescah crops out in eastern Harper County but yields little or no water to wells in the area except from the upper weathered zone in the outcrop area, where small quantities of water are available locally.

The Hurper sandstone and the Salt Plain formation overlie the Ninnescah in Area 5. The Stone Corral forization, which lies between the rinnescah formation and the Harper sandstone in other areas of the state, if absest in Harper County. The Harper sandstone and the Salt, Plain fcrmation are composed princlpelly of red, silty shale but locally contain thin beds of fine sandstone. Their combined thickness in this irea is about $500 \mathrm{ft}$. Water is generally not available from the Harper sandstone or the salt Plain formation in this area except for small supplies, locall:', from the sandstone beds. 
Deposits believed to be a part of the Ogallala formatica of Pliocene age crop out in the southeastern part of Area 5 in a high upland position. These outcrops are thin and largely composed of sand and gravel derived from Cretaceous and Permian rocks. These deposits yield no water to wells in the area.

Pleistocene sand and gravel deposits or the Nebraskan and Kansas stages are present in the uplands in northerr and northwestern Harpei. County. These deposits are as much as $100 \mathrm{ft}$ thick and, locully, may yield as much as $300 \mathrm{gpm}$ of water to wells.

Kansan age diposits occur in a high terrace position along Bluff Creek in the southern part of Area 5. In this area, much silt is present in the deposits and yields to wells are generally low.

Sand and gravel in channels beneath tilick silt, deposits occupying the slope between the upland rebraskan and Kansan deposits and sand Creek Valley in the area near and east of the city of farper are probably Illinoian in age. These deposits may yield as w'xh as 500 gpm of water locally.

Alluvium and low terrace deposits in and adjacent to the stream vaileys yield only small quantities of water to wells.

Population and Transportation. - Population centers in Area 5 are located along rail roads. The Kiowa Branrh of the Atchison, Topeka, and Sarte Fe Railroad end several other branch lines of the Santa Fe serve the area. A brinch line of the Missouri Pacific Railroad serves the southern part of the area. U.S. Highway 160 crosses the area in an eastwest direction; severai state higbways cross the area in both east-west and north-south airections, thereby connecting all of the cities to the highway system.

UiI and Gas. - A portion of the Spivet.Grabs-Basil oil and gas field, one of the larger flelds in Kansas, covers wuch of the northwestern part of Area 5. Several smaller fields sre located principally in the northern and eastern parts of the area. Nanj exploration holes have been drilled thrnignout Harper County. Most producing wells have not d large initial yields, but they have continued to priduce for many years. The area is considered to have good potential for future exploration. 
Salt. - In Area 5 the Hutshinson salt occurs at a depth of about $55 \mathrm{C} \mathrm{ft}$ in the northeast and about $1000 \mathrm{ft}$ in the nortinwest and southwest. The thickness of the salt ranges from about $200 \mathrm{ft}$ in the east-central part of the area to about $400 \mathrm{ft}$ in the west. The salt is about $350 \mathrm{ft}$ thick in the area of least drilling activity. Although the qliality of the sait in this area is the poores $i$ of that in any of the eight areas studied, the absence of water above the salt beds makes Area 5 suitable for consideration.

Area 5. - Area 6 (Fig. 2.12) includes 12 townships in western Reno County, north of the North Fork Ninnescah River. The southern portion of the area is drained by the Ninnescah River; the rorthern portion is drained by the Arkansas River. Structurally the area lies in the northwestern part of the Sedgwich Basir and on the eastern flank of the Sentral Kansas Uplift.

Geology and Hydrology. - Lower Permian rociks consisting of part of the Wellington formation, the Nirnescah shale, and the Stone Corral formation occur above the Hutchinson salt but do not crop out in Area 6. The upper portion of the Wellington formation consists of about $200 \mathrm{ft}$ if principally gray shaie, although it contains some red shale near the top and a few thin beds of anhydrite and dolomite. The Ninnescah shale is composed of about $300 \mathrm{ft}$ of red shale and minor amounts of siltstone. The Stone Corral formation is comprised of about $20 \mathrm{ft}$ of anhydrite and dolomite. Little or no water is available from these rock units in this area.

The Harper sandstone, which overlies the Stone Corral formation, is the oldest rock unit that crops out in Area 6. This unit, composed of silty shale and siltstone, is about $150 \mathrm{ft}$ thick and dominantly red in color. The Harper sandstone yields small quantities of water to a few wells from the upper weathered part of the formation.

Sand and gravel deposits that contain considerable quantities of silt and are believed to be part of the Ogallala formation of Pliocene age are present in an upland position ir. the southern part of Area 6 . These deposits are red or dark reddish-brown and are composed of materials largely derived from Permiar, and Cretaceous rocks. They occur in relatively 
thin, sheetlike deposits. Other sand and gravel deposits, similar in lithology and color, occur in channels in this same general area but at a somewhat lower elevation. These deposits may be earliest Pleistocene in age (Nebraskan) and derived from the older Ogallala deposits. Small to moderate quantities of water are available to wells from the se deposits.

A deep channel cut into the Permian bedrock extends southeastward from the northwes i corner of the area to a point about 7 miles south of the norineast cr,rner of the area. This channel is filled with Pleistocene stream deposite. The lower part, locally as much as $100 \mathrm{ft}$ thick, contains red and reddish-brown sand and gravel similar to the channel deposits in the southern part of the area. These depcsits, which are thought to be Nebraskan in age, contain highly mineralized water. The Nebraskan deposits in the channel area are overlain by younger Pleistocene deposits of probable Kansas and Illinoian age. These younger sheetlike deposits underlie the surface and rest on Permain rocks throughout all of Area 6, except in and near the valley of the Minnescah River. The Pleistocene deposits may be as much as $100 \mathrm{ft}$ thick and yield jarge quantities of water to wells in locel areas.

Dune sand, principally of Wisconsinan age, overlies the earlier Pleistocene deposits in a significarit portion of the area. The dunes are well stabilized in most of the arsa; howevis, some of the dunes in the northrest are active and drainage is poorly developed.

Thin loess deposits overlie the Kanst:s and Illinoian deposits in the southeastern part of Aren 6.

Recent alluvium and low terrace deposits are present in the valleys of the Arkansas and Ninnescah rivers. In the Ninnescah Valley, these deposits are thin and only moderate quantities of water are available. Yields of wells in excess of 1000 gpm are obtained in the Arkanses River Valley.

Population and Transportation. - Population centers are located along the main lines of the Rock Island and Pacific Railroad in the southern part of Area 6, along the main line of the Atchison, lopeka, and Santa Fe Rellroad in the central part, and along the Great Bend 
Branch of the Santa $\mathrm{Fe}$ in the north. The largest city within the area is Arlington, which kad a 1970 population of 503. Hutchinson, lccated about 12 miles east of the area, had a 1970 population of 36,885 .

U.S. Highway 50 crosses the aree in an east-west direction, and State Highway 14 crosses the eastern portion of the area in a northsouth direction. State Highway 61 crosses the area in a northeastsouthwest direction in the southern portion of the area.

Oil and Gas. - The Zenith-Peace Creek Field in northwestern Reno County dominates the oil and gas production in Area 6. Other smaller fields occur in the northern two-thirds of the area. Production is from rocks ranging in age from Ordovician to Permian. Large areas are present in the southern part of Area 6, where no production has been obtained although the area has been extensively drilled.

Area 6, locatea in the northwestern part of the Seagwick Basin and on the eastern flank of the Central Kansas Uplift, has possibilities for additional production from stratigraphic traps.

Salt. - The Hutchinson salt occurs in Area 6 at depths of about $700 \mathrm{ft}$ in the sastern section to about $1000 \mathrm{ft}$ in the rest, and ranges in thickness from $350 \mathrm{ft}$ to about $435 \mathrm{ft}$. The thickest salt deposit occurs near the center of the area, where it overlies a structural high. The possibility that thickening of the salt was the result of mass flow was investigated in one ?hase of this study. It was found that the correletion between the thicker salt sections and the structural highs could be satisfactorily explained by facies changes, pinchout, overlap, and other original depositional. features. The quality of the salt in Area 6 is intermediate between that of Lyons and that of Area 5, and somewhat better than that of the salt of Areas 2 and 3.

Area 7. - Area 7 (Fig. 2.12) includes all of Rice County, which is located near the center of the State. The area is drained on the south. and west by the Arkansas River and on the east by the Iittle Arkansas River. A small area in the northeastern part of Rice County is drained by tributaries of the Smoky Hill River. The eastern part of the area lies within the Sedgwick and Salina basir.s. The western one-half of the county is located on the flank of the Central Kansas Uplift. 
Geology and Hy:irology. - The upper pert of the Wellington formation between the top of the Hutchinson salt and the base of the Ninnescah shale ranges in thickness from about 250 to about $300 \mathrm{ft}$. The Wellington is composed principally of gray and blue-gray shale but contains thin beds of red shale and anhyürite. Little or no water is available from the unit in this area.

The upper part of the Ninnescah shale crops out in eastern Rice County. This unit, which is composed chiefly of red and reddish-brown shale, is about $300 \mathrm{ft}$ thick in the area. Only about the upper $50 \mathrm{ft}$ of the unit is exposed. The Ninnescah rontains little or $m$ water except in the upper weathered part, which yields small quantities of water to wells in the outcrop area.

The Stone Corral formation overlies the Ninnescah shale and crops out in eastern F.ice county. On the outcrop, the Stone Corral is about $6 \mathrm{ft}$ thick and is cumposed principally of dolomit.e. West of the outcrop, the Stone Corral is about $18 \mathrm{ft}$ thick in the subsurface and is composed of anhydrite, dolom:te, gypsum, and shale. The Stone Corral yields small quantities of water to weils in the area of outcrop and contains only small quantities of water near the senter of the county. The Stone Corrai con.. tains little, if ar.y, water in the northern and western parts of the county.

The Harper sandstone, overlyirug the Stone Corral, is the youngest Pimian rock unit in Area 7. The Harpez is about $1.50 \mathrm{ft}$ thick in places where a full section is present. The unit is composed principally of red, silty snale and red siltstone and yields little; or no water to wells in the area.

Lower Cretacenus rocks overiie the Harper sandstore in this area. The contact between these rocks and the Permian rocks marks a major unconformity in this area. The oic'est Lower Cretaceous rock unit in Kansas is the Cheyenne sandstorie, which cverlies the rermian Harper sandstone in the western part of Area 7. The Cheyenne is composed of very fine, silty sandstone and siltstone and is not an important aquifer. The Cheyerne does not crop out in this area. 
The Kiowa formation overlies the Cheyenne sandstone in the western part of Rice County. Eastward the Kiow overlaps the Cheyenne and rests un the Harper sandstone. It j.s about $150 \mathrm{ft}$ thick in places where a full section is present; however, it thins to zero thickness toward the south and east. The availability of water in the kiowa is dependent on the presence of the sandstone beds as well as on their thickness (a few inches to several tens of feet). Yields of wells range from oniy a few gallons per hc גr to as much a: 50 gpm.

The Dakota formation overiles the Kiowa formation in the northern part of Rice County, and may reach a thickness of $200 \mathrm{ft}$. The unit thins to zero thickness boward the south. It crops out principally in the headwater area of the Little Arkansas River. In the north-central and northwestern parts the Dakota is overlain by silts of Pleistocene age and crops out only in small isolated areas. This formation is principally composed of clay, shale, and sandstone but contains some lignite and beds of iron-cemanted sandstone. Colors rarge from red, brow, and gray t.o whit?. Sancistone beds occur throughout and may comprise about one-third of the total thickness. The quantity of water that may be obtained by wells from the Dakota is dependent on the aroount of sandstone present. Maximum yields are probably about $200 \mathrm{gpm}$; however, smaller yields are more cummonly obtained.

The Ogailala formation of Pliocene age is represented in this area by a soil caliche formed during the long period of weathering that occurred prior to Pleistocene deposition in the area. The soil caliche is thin and not, present everywhere.

Pleistocene rocks unconformably overlie the bedrock units in much of Area 7. Alluvial deposits are present in the valleys of the Arkansas River, Cow Creek, and the Little Arkansas River. Early Pleistocene channel deposits underlie alluvial deposits in the west-central part of the area roughly parallel to Cow Creek and in the south-central part of the area underlying the valleys of the Arkansas River and Cow Creek. Large quantities of water are aveilaile from these deposits.

Dune sand overlies the alluvial deposits in the valleys of the Arkansas River and Cow Creek. It overlies channel deposits on Cretaceous 
rocks in west-central Rice County and Permian rocks in southeastern Rice County. The dune sand deposits are not important aquifers in Area 7.

Loess underlies the surface in much of the upland areas of the county. Very small quantities of water are available to wells locally from these deposits; however, most wells penetrate the deeper rocks to obtain more dependable supplies.

Popuration and Transportation. - Population centers in Rice Ciunty are located along railroads serving the area. Lyons, the largest city, is located near the center of the County and is served by branch lines of the Atchison, Topeka, and Santa Fe Railroad, the Missouri Pacific Railroad, and the St. Louis and Sen Francisco Railroad. The main line of the Missouri Pacific Railroal serves population centers in the extreme northern part of the county. The city of Sterling, in the southern part of the area, is served by the Great Bend Branch of the Santa Fe Railroad.

U.S. Highway 56 passes east-west through the center of the county. State Highway 4 passes east-west through the extreme northern part of the area, and State Highway 14 crosses north-south through the center of the area.

Oil and Gas. - Rice County is one of the most heavily drilled areas in Kansas. Cil and gas fields occur throughout Area 7, and many exploratory holes have been drilled outside the fields. Production has been obtained from rocks ranging in age from Precambrian to Permian. The western part of the area is located on the eastern flank of the Central Kansas Uplift; the eastern part lies in the westernmost sections of the Salina and Sedgwick basins. Although the area is already hijhly developed, exploration is expected to continue at a high level of intersity.

A natural gas storage area is located near Alden (in the southwestern part of Rice County).

Silt. - In Area 7 the Hutchinson salt occurs at depths ranging from about $450 \mathrm{ft}$ in the east to about $1000 \mathrm{ft}$ in tic rest. The thickress of the salt ranges from 230 to about $390 \mathrm{ft}$. The qualiiy hare is simijar to that of Area $i$ and somewhat better than that of Areas 5 and 6 . 
Area 8. - Area 8 consists of a large area of far-westerr Kansas, which is composed of Wallace, Logen, Greeley, and Wichita counties and a smail part of western Scott County (Fig. 2.12). The northein half or the area is drained by the anoly Hill River; the southern part is drained by White Woman Creek, hich empties into the Scott-Finney depression and has no connection with major trunk streams. The area lies in the nurthern part of the Hugoton Embayment.

Geolcgy and Hyirology. - Permian rocks between the Blaine formation (Lower Permiar) and the Morrison formation of Jurassic age thin toward the north and east in this area. The Permian section of rocks is about $320 \mathrm{ft}$ thick in Greeley County. It is about $280 \mathrm{ft}$ thick in Wichita County; and about 170 and $150 \mathrm{ft}$, respectively, in Wallace and Logan counties. Thinning is probably due to post-Permian--pre-Jurassic erosion. Generally the rocks are composed principally of silty to sandy shale; however, the Whitehorse formation in Area 8 contains sandstone and should yield some highly mineralized water to wells.

The Morrison formation in this area is about $100 \mathrm{ft}$ thick and is composed principally of shale and sandy shale but may contain thin beds of limestone locally.

The Lower Cretaceous Cheyenne sardstone, the Kiowa formation, and the Dakota formation have a nearly constant aggregate thickuess of about $400 \mathrm{ft}$ in Wichita, Creeley, Wallace, and Logan counties. Both the Cheyenne and the Dakota contain appreciable amounts of sandstone anä should yield moderate to large quantities of water to wells. Water from the Dakota is locally of usable quality, but Cheyenne wetar is probably too highly mineralized for use.

Upper Cretaceous rocks between the top of the Dakota and the base of the Niobrara chalk are composea of shale, chalky shale, limestone, and chalk. These rocks comprise the Graneros shale, Greenhorn limestone, and Carlile shale and are about $400 \mathrm{ft}$ thick. Little, if any, water is available from these rocks.

Ine oldest bedrock unit that crops out in this area is the Smoky Hill chalk mamber of the Niobrara chalk. Although this unit is extensively 
exposec is the ralley of the Smoky Hill Rirer in Logan County, it crops out only in small exposures in the valiey of Chalk Creek in Scott County. It is not exposed in Wichite county. In parts ce Wallace and Iogan courities the kiobrara chalk is abont 650 ft thick where it has not been eroded. In noithwestern Wichita county the Notrars is about $500 \mathrm{ft}$ thick but tinins toward the south and east.

The Pierre shale overlies the Niobrara chalk in parts of Wallace and Iogan counties. The Pierre may be as much as $600 \mathrm{ft}$ thick locally in Wallace County but thins toward the east where it has been eroded. This unit may be present below the Ogallala formation in northorn Greeley county, even though it is apparently absent in Hichita and Scott counties.

Earliest Ogaiiala deposition occurred in relatjvely shallow, broad channels cut in the eroded and beveled Cretaceous surface. Continued deposition of these clastic deposits soon filled the chamels and, by middle raillala time, had topped the divide areas between the channels. At the end of Cgallala time, this ires, wost of western Kansas, and large areas in adjoining states formed a broad alluvial plain with a gertle eastwerd slope. Since the end of Ogellala deposition, several bundred feet or Igrilala and Upper Cretaceous rocks has been eroded in the valley of the Srooky Hill River. The thiakest Ogallala deposits in Iogan County ere presently found in the northern part. These deposits thin to zer's thickness toward the Smoky Hill River Valley. Thin deposits of Ogallala occur in the uplands in western and soutinrestern Logan County.

In Wallace County more than $300 \mathrm{ft}$ of Ogallaiz is present in lockl areas; however, the normal thickneas is considerebiy leas. The Cgallala is quite thick in north-central and northeastern Greeley County, wlthough somewhat thinner than in Wullace County. In western and southern Greeley County it ranges in thickness from 150 to about $200 \mathrm{ft}$. The formetion thins to less than $50 \mathrm{ft}$ in local areas in the southero part of ilichita and iresley counties.

iloderate to large supplies of water are obtained frum the Ogallala in northern Logan County. In Waliace County, where the thickeet deposits occur, wells yielding as much as 1500 grm are obtained; however, well. 
yields of about $1000 \mathrm{gpm}$ are more common. In western and southern Greeley Counti, where the Ogallala is thin, much less water is available to wells. In northern Wichita and Scott counties, yields of wells are commonly about $1000 \mathrm{gpm}$. Xields of wells diminish southward in these counties, and only small quantities of water are available in the extreme southern part of the area.

During the Pleistocene several hundred feet of older deposits were eroded in Logen County and in the eestern part of Hallace County.

Pleistocene fiuvial deposits occur as low terrace deposits or alluvium in the Smoky Hill Valley and in the valleys of the lerger tributaries. Erusion during this perlod was much less severe in Greeley and wichita counties and in the western part of scott County. In eastern Wichita County, White Woman creek flows about lon ft below the highest upland: on either side of the stream. The degree of erosion was probabiy controlled by the fact that White Woman Creek flows into a closed basin and does not have surface sccess to a through-flowing stream. Thin alluvial deposits of Pleistocene age occur in the valleys cf White Woman and Iadder creeks in these counties. Larger water supplies are generally not available from Pleistocene deposits in the western part of Scott County or in Wallace, Iogan, Greeley, and Wichita counties, except locally in the Smoky Hill River Valiey.

Loess, principally of late Pleistocene age ranging up to $50 \mathrm{ft}$ in thickness, overlies older deposits in wuch of Area 8. In the upland areas the loess overlies Ogallala deposits. In the valley of the Sroky Hill River, thin loess overlies Cretaceous rocks in local areas.

Faulting and Solution Features. - Mmerous sall faults can be observed in the Cretaceous rocks in Wallace and Logan counties. Venerally, displacement along faults is small; however, a displacement of as much as $35 \mathrm{ft}$ has been observed in Wallace County. From our present knorledge of the area, it is not known shether faulting affects deeply buried rocks in the area or is confined only to the Cretaceous rocks. Faulting is seen only in the Cretaceous rocks and does iot appear to bave affected the Ozallala or youiger deposits. If the faulting is deep seated, it 
no doubt extends beyond the aree where it can be observed. On the other hana, if the faulting is related to adjustments that may have occurred due to unloading of the Cretaceous rocks when great quantities of ovei lying rocks were eroded, the faulting may be relatively shallow and confined to the valley area where erosion occurred.

Two instances of development of sinks or collapse of surface rocks have occurred in Wallace County since this area has been inhabited - one in 1900 and the other in 1926. The area affected by the latter measured about 350 by $250 \mathrm{ft}$ and was reported to be 300 to $500 \mathrm{ft}$ deep before being filled with water from the Swoky Hill River. Other aress of sinking in which Cretaceous rocks are affected have been observed in Hallace County. These may represent collapse features that occurred before the area was inhabited. The abnormal saturated thickness or the Ggallala in lucal aress in Mallace County way be an inaication of 0:1 collapse featwas. Tho similar collarise features have been observed in Logan County.

The cause of the collapse of surface rocks nej be atiributed to the chaik or, if the faulting in the area is deep-sicted ari iffects the deeply buried rocks, dissolution of salt may have occurres, thereby pernitting the cverjying beds to collapse. Chali is soluble in water to some extent, eapecialiy if the water is sightly acidic. However, in Area 8, large quantities of water are not known to occur in the chalk; nor is the cinalk caveinous on the outcron.

Large quantities of water are araijable in the Lower Cretaceous rocks several hundred feet above the maine salt. Migration of this water downward through the salt via fractures or faults could have caused dissolution.

Population ani Transportation. - Pepulation centers in Hallace and Iogan counties, with the excrption of Ruzsell Springs (Iogan County), are located along the Union Pacific Railroaci, which enters the area at the northeast corner of Togan County and enters Colorado near the center of the rest line of Wallace cointy.

The only incorporated cities in Wichita and Greeley counties are located near the centers of the counties, along the Missouri Paciric Rail road. 
Wallace and Logen counties are serred by U.S. Highway :-0, which passes east-west through the area. Siate Highway 25 crosses Logan and Wichita counties in a north-south direction. State Highwriy 27 crosses Wallace and Greeley coumties from north to south. State Highray 96 is an east-west highway serving Wichita and Greeley counties.

Oil and Gas. - Only a limited awount of oil and gas drilling has been done in Wallace, Logan, Greeley, and Wichita counties and in the restern part of Scott Courty. Production from a few wells has been swall. This area is in the northern part of the Hugotun Babayent, nurth of the large Hugoton Gas area. At the fresent time the part of eastern Colorado that adjoins Area 8 is receiving considerable attention bj oil operators. There is considerable potential for finding production from structural and stratigraphic traps in Wallace and Greeley counties. Fer wells have been drilled in Wichita County, and only minor oil and spoduction has been obtained in this area.

Salt. - Ares 8 was inclucied in tzis study when it was recognized that salt jerosits just below grpsy beds of the Blaine forsation net the assigned stuity parameters of thickness and depth. This salt deposit is referred to as the Baine salt. In northrestern Hallace County the Baine salt occurs at a depth of about $2800 \mathrm{ft}$ and is only about $100 \mathrm{ft}$ thick; in central Ingan County it occurs at a depth of about $1750 \mathrm{ft}$ and is nearly $300 \mathrm{ft}$ thick but thins rapidly torard the north and east. The Baine occurs at a depth of about $2000 \mathrm{ft}$ and is about $300 \mathrm{ft}$ thicis in eastern Greeley County; however, the depth to ealt increases and thr thickness decreases toward the west. In nothwestern Wichita County the sait occurs at a depth of about $2000 \mathrm{ft}$; in soutineastern Wichita and western Scott counties it occurs at about $1450 \mathrm{ft}$. The thickness ranges from ebout $350 \mathrm{ft}$ in the north to about $440 \mathrm{ft}$ in the south. Results of a study of core description and radioactive logs indicate that the salt in this area is of better quality than that in any of the other areas examined.

Sumary and Ranking. - Based on the information collected in this study, the Ransas Geological Survey ranked the elght areas according to their suitability as Pollows: 
Area ? appears to be the best prospect for future study. It is distant from regional oil and gas development and offers large areas "rom which sites having very few or no existing oil wells within the buffer zones could be selected. The character and quality of the salt deposit appear to be suitable.

The likelihood of unknown hydraulic connection between the salt and an aquifer above or below the salt in Area 1 caused by an old drill hole or fracture pattern is slight. The potential for oil and ges derelopment is considerably less than in any of the other seven areas considered.

Area 8 (eastern part) contains a rather thick salt deposit of high quality absut $1700 \mathrm{ft}$ deep and consequently is rated above all other areas except Area 1. Furihermore, it lies in extrene vestern Kansas, far to the west of major regional oil and gas producing areas. The western part of the area is on the eastern fringe of an oil and gas developent in eastern colorado and, therefore, will probably undergo vigorous exploration even though it is largely undrilled at the present. Adational problea: in this pert of the area could be anticipated becalse of snowalous structural and bydrologic conditions.

Area 5 is ranked next because this area has considerably les: ground water above the salt than any other area. Of course, this advantage must be balanced against a salt forrition which appears to be of marginal thickness and pour quality. Although ofl and gas exploration hes been active, sparsely drilled areas do exist.

Area 6 lies to the south of the Lyons site on the southeast flank of the regional oil ard gas developmer.t trend. The area bas been, is helns, and will continue to be actively explored. The salt deposit is somewtat thicker and shallower than at Lyons and should be of comparable q. ality. Problems involving water above and helow the salt beds wil be as great as in sw area studied. Because of old oll and gas boles and coplous quentitifes of ground water in the area, Area 6 ranks below Areas 1 and 5, but above Areas 2, 3, and 4.

Area 2 lies on the western side of an area of regional oil and gas developwent. It is now undergoing sctive exploration and, in addition, 
has good potential for future oil and gas development. The area is marginal in terms of the properties of the salt deposit in that it is nearly $2000 \mathrm{ft}$ deep. The potential for problems relative to water above and beliw the salt, in addition to old holes and depth to salt, makes this area a yoor candidate for further study.

Area 3 can be categorized much the same as Area 2 and is a poor prospect for future study.

Area 4 lies to the west of regional oil and gas developaent and to the east of a large area that appears to bave undergone some salt dissolutioning anci faulting. The study area has been (and is etill being) actively explored for oil and gas. This area, like Areas 2 and 3, is marginal in meeting the requirenents of thickness, depth, and purity of the salt deposit. The salt is about $1700 \mathrm{ft}$ deep. Probiens concerning water above and below the salt, existence of old boles, depth to salt, and salt dissolutioning imediately to the west nake Area is a poor prospect for future study.

Area 7 lies on the cast flauk of the reglonal oil and gas developant. This area contains the largest muber of producing wells, the greatest history of exploration, and the highest potentlal for future development of any area considered. The salt deposit is of good quality, ranges in depth fron 450 to $1000 \mathrm{ft}$, and is 230 to $390 \mathrm{ft}$ thick. (This area contains the Lyons site.) Mediun to low grantities of ground rater exist above the salt. Large number of old oil and gas holes, the presence af water above and below the salt, possible deep-seated structural problems, a high potential fcr development in the future, and an inadequate buffer zone make Area 7 the poorest candidate for fiture study.

\section{¿.2.2 Site Bxplorations}

The second phase of the site recommissance work in Kansas irvolved the identiflcation and more-detalled examination of three specific sites. This was accomplished by first identifying three areas of approximateiy 36 square miles each, based on the concluslous of the screenirg survey and on the information complied in that survey. Tro of these areas were located in Lincoln County (Study Area 1); the third was in Wichita County 
(eestern part of Study Area 8). The best specific site, encompassing approximately 2 square rfies, in each of these three areas was then selecied. This selection was based on fleld reconnaissance of the areas, with particular attention being paid to topographic and cultural features. The three sites, identified as $A$ and $A_{1}$ in Lincoln County and $D_{1}$ in Wichita County (see Fig. 2.12), as well as the area irmediately surrounding them, were then further investigated. These investigations consisted of continued field surveys and the drilling and testing of a core hole through the salt formation at each of the three sites. The results of these investigations are discussed below.

Site A. - Site A is located in south-central Lincoln County, Kansas, and inciudes the SE $1 / 4$ Sec. $21, S 1 / 2$ Sec. 22, all of Sec. 27 and the E $1 / 2$ Sec. 28, T. 13S., R. $8 w$.

Topographic, Surface Geologic, and Cultural Peatures. - Most of the area within a 5-mile radius of the site is drained by tributaries of the Saline River. A drainage divide is located about 5 miles south of the site. South of the divide, drainage is to the Smoky Hill River. Spring Creek, west of the site, and Bikhorn Creek, east of the site, generally maintain a small flow throughout the year but may cease to flow during prolonged drought periods.

The topography consists of relatirely lat-topped hills with steep walls breaking dormard to relatively narrow velleys. Maximn relief 18 about $250 \mathrm{ft}$, in the 1440 -acre site area, the hill tops are underlain ty thin deposits of carlile shale. These deposits have a waximum thickness of about $20 \mathrm{ft}$ in this area. The escarpment neer the edge of the hill tops is held up by the Greenhorn limestone, wich is about 65 ft thick in this area and extends well down the hill slopes. The Graneros shale underlies the Greenborn and is about $30 \mathrm{ft}$ thick. This unit generally occupies the lower part of the slope. The Dakota forwation 18 locally present in the lowest part of the hill slopes and underlies thin collurial or alluvial deposits in the valiey bottoms.

High-pressure natural ans lines traverse this part of Iincoln County. Two parallel lines, which run in a nor th-south direction, are present adjacent to the east side and partially within the 1440-acre 
site area. There are no service connections to these iines within 3 5-mile radius of tine site. The lines are owned by the Cities Serrice Company. Four high-pressure natural gas lines running in a northeastsouthwest direction are present abort 5-1/2 miles northwest of the site. These lines are owned by the Pipeline Company of America. No service connections are present within the area.

A buried communications cable trendine north-south crosses the area about 1 mile east of the site. This cable sonnects with an east-west trending cable, wich is about I mile south of the site at its nearest point. These cabies are operated ty the Beii system. Another buried carle, which is operated by the United States Air Force, runs in an east-west direction about $3-1 / 2$ miles south of the site. Local service is furnished residents in the area by aboveground lines.

Electric power is supplied to the local residents by the Sunflower Electric Cooperative. Most of the power lines serving the area are single-phase, $7200 . \mathrm{V}$ lines. A three-phase $7200-\mathrm{V}$ line runs west along the section line 3 miles south of the site. A main power transmisc:on line crosses the general area in a northwest-southeast direction about 2 miles south of the site. This line, which is owned by the Central Kansas Power Company, is designed for $230,000 \mathrm{~V}$ but is presently energized at $115,000 \mathrm{~V}$.

Hydrology. - The area surrounding Site A is generally well supplied with domestic and stock water supplies. Although the Dakota formation is the principal aquifer in the area, a few wells obtain water from alluvium or colluvium in the stream valleys. Although some wells are located on the tops of hills, mast are locater or the slopes or in the valleys. Depths of wells in the aree are quite variable, ranging from about $30 \mathrm{ft}$ in some valley areas to more than $300 \mathrm{ft}$ in upland areas where Lower Cretaceous rocks are fully penetrated.

The po:ential yields of wells in this area are difficult to estimate. Generally, stock and domestic wells are not filly penetrating but are only deep enough to furnish the required quantity of water. Records were obtained for only three wells that produce appreciable quantities of water. A well located just south of Interstate Highway 70 near the 
south border of Sit.e A produced $195 \mathrm{gpm}$, and another well located adjacent. to I-70 about 8 miles west of the site produced about $100 \mathrm{gpm}$. A third well located about 3 miles south of the city of Lincoln prcduces about $250 \mathrm{gpm}$. All of these wells obtair. water from Lower Cretaceous rocis.

Core Drilling. - The test hole (AEC No. 3) was drilled at the northeast corner of the site at a ground elevation of $1620 \mathrm{ft}$. The fornations penetrated and their depths and thicknesses are show in Fig. 2.13. In general, the formation contacts were slightly lower than had besin predicted, based on correlations of logs from nearby oil and gas test wells. As a consequence, the thickness of the Hutchinson salt (157 ft) was considerably thinner than the $240 \mathrm{ft}$ expected. The sections of the hole which were cased and those which were cored are also shown in Fig. 2.13.

Hydrologic Testing. - The U.S. Geological Survey performed hydrologic tesis in each of whe three holes. In general, tha objectives of these tests were: (I) to confirm the expected extremely low permeabilities immediately above and below the salt section, which is an indication that natural dissolutioning has not occurred, ana (2) to determine the yuantiti of water available in aquifers above the salt as a part of the asseissment of the potential for future dissolutioning. The results of these test.s are summarized in Table 2.4.

For AEC HCle No. 3 at site A, these results can be interpreted as follows: First, tests 1 and 2 indicate that the zone immediately below the salt (depth, $957-1100 \mathrm{ft}$ ) is very tigkt and has a very low permeability. The zone immediatsly above the sait, (409-967 ft, by difference) is also tight and has a low permeability, although not quite as low as the zone below the salt. Test 3 was performed by pumping the well after having perforated the casing opposite the sandstones of the Lower Cretaceous (Dakota). Results of the test indicated that a properly constructed well at this location probably would produce at least $300 \mathrm{gpm}$ of wher, which is a'sequate for stock or domestic supplies and might be suffinient for some sprinkler irrigation. This yield was somewhat more than had been expected. 
AEC HOLE NO. 3

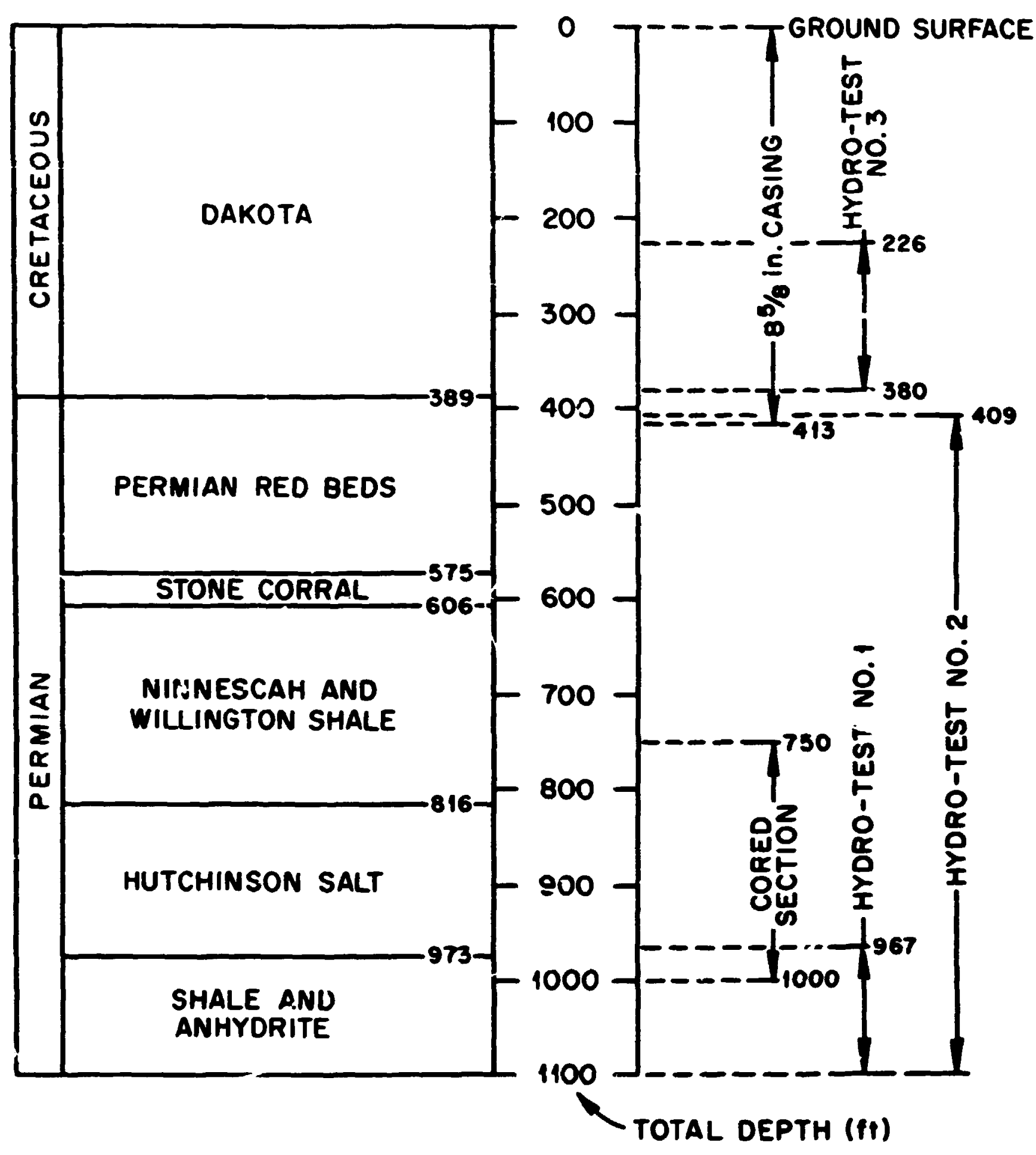

Fig. 2.13. Simplified Geologicai Log of AEC Hole No. 3. 
Table 2.4. Summary of Hydrologle Tests

\begin{tabular}{|c|c|c|c|c|c|c|}
\hline $\begin{array}{l}\text { Hole } \\
\text { bo. }\end{array}$ & $\begin{array}{c}\text { Test } \\
\text { 110. }\end{array}$ & $\begin{array}{c}\text { Interval Testea } \\
\text { (ft below } \\
\text { Iand surfece) }\end{array}$ & $\begin{array}{l}\text { Static Water } \\
\text { Levei (ft below } \\
\text { land surface) }\end{array}$ & $\begin{array}{c}\text { speciflc Capacity } \\
\text { (or Relative S.C.) } \\
\text { (opm per ft of } \\
\text { drawdown) }\end{array}$ & $\begin{array}{c}\text { Transmissivity } \\
\left(\mathrm{gpd} / \mathrm{f}^{\circ} \mathrm{i}\right)\end{array}$ & $\begin{array}{c}\text { Type of } \\
\text { Test Performed } \\
\end{array}$ \\
\hline 3 & 1 & $967-2100$ & $211.61^{a}$ & $2.4 \times 10^{-8}$ & $3.9 \times 10^{-3}$ & Slug (swabbing) \\
\hline 3 & 2 & $409-1100$ & $211.61^{2}$ & $6.5 \times 10^{-4}$ & $1.5 \times 10^{-i}$ & Slug (swabb:ag) \\
\hline 3 & 3 & $2.26-380$ & 186.19 & 7.26 & 16,400 & Pumpiig (drewdown) \\
\hline 4 & 1 & $1186-1275$ & 262.46 & $3.1 \times 10^{0.8}$ & $5.3 \times 10^{-3}$ & Slug (swabbing) \\
\hline 4 & 2 & $650-1275$ & 262.46 & $5.8 \times 10^{-4}$ & $6.0 \times 10^{-3}$ & Slug (swabblng) \\
\hline 4 & 3 & $408-5 i 3$ & 201.44 & 2.71 & 8,670 & Pumping (drawdown) \\
\hline 5 & 2 & $1950-2150$ & $928.47^{\circ}$ & $2.6 \times 10^{-6}$ & $8.6 \times 10^{-4}$ & SIug (Injection) \\
\hline 5 & 2 & $2214-2150$ & 928.47 & $2.4 \times 10^{-6}$ & $2.6 \times 10^{-2}$ & SIug (Injection) \\
\hline 5 & 3 & $1259-1.376$ & & b & $b$ & slug (injection) \\
\hline 5 & 4 & $74 ? .980$ & 556.00 & $0.083^{c}$ & $160^{c}$ & Pumping (drawdown) \\
\hline
\end{tabular}

Indicates an estimated value.

bee text.

CValue based on slug withdrawal amalysis. 
Salt Core Examination. - Detailed examination of the core samples obtained from AEC Hole No. 3 (see Fig. 2.13) indicated that the salt is of the same general character as that encountered at the Lyons site. Correlation of the core with logs from this well and nearby wells was sufficiently good to suggest continuity of the major beds. The top and bottom contacts of the salt formation were recovered intact. At the top contact, there was a small zone of missing salt marled by an anhydrite-shale breccia zone, immediately above which the sequence was horizontal. This indicates that dissolution occurred before deposition of the overlying material and was not associated with recent ground-water ectivity, which confirms the results of hydrologic tests in the well.

Three zones of good-quality salt, each approximately $20 \mathrm{ft}$ thick, were identified in the depth rarge of 876 to $942 \mathrm{ft}$. These zones would be of potential interest for waste disposal operations.

Site $A_{1}$. - Site $A_{1}$ is located in northwestern Lincoln County and includes all of sections 8 and 17, T. 11S., R. 10W.

Topographic, Surface Geologic, and Cultural Features. - The area surrounding this site is drained by tributaries to the Saline River. Although rust of the streams within the 2-square-mile area are not perennial, Spillman Creek, which drains much of the northeast part of the area, flows most of the time except during prolonged drought periods. Wolf Creek, on the south, maintrins some flow at oll times.

Topographically, Site $A_{1}$ is a relatively high upland. The area, which is flat to rolling, is underlain ky thin loess deposits overlying the Upper Cretaceous Carlile shale except in the southrest corner, where the upper part of the Greenhorn limestone crops out in the vulley of a small sueen. The Graneros shale and the Dakota formution, the oldest exposed rocks, crop out about 2 miles south of the southern part of the 2-square-aile area. About 30 ft of Carlile is present in this area. The Greenhorn is about $90 \mathrm{ft}$ thick and is underlain by 40 to $50 \mathrm{ft}$ of Grareros shale. The combined thickness of the Dakote and Kiow formations 18 approximately $420 \mathrm{ft}$. Alluvial deposits occur in Spillman Creek Valley and in Wolf Creek Valley. 
One 12-in. arude oil pipeline traverses in a west-northwesterly to eest-southeasterly direction about 1.5 miles north of the 2-square-mile area. This line is owned by the Amo:o Pipeline Company.

No buried communications cabjes, except service cables extending from the overhead lines to the service outlet, were observed within a 5-mile radius of this site.

Electric power in this area and to the south is furnished by singlephase, 7200-V lines ormed by the Surfiower Electric Cooperative. North of this area, power is furnished by the Mankato-Jewell Electric Cooperative. The nearest three-phase service is at either Lucas or Sylvan Grove.

Hydrology. - This area is, in general, adequately supplied with water. The Dakota formation is the principal aquifer. Alluvium in the valleys of Wif Creek and Spillman Creek yields moderete supplios of water to wells within a 5-mile radius of the 2-square-rile area. The quantity of water available from many of the wells in the allurium is sufficient for stock or domestic supplies. One well ir Spiliman Creek Valley is reported to have an initial yield of about 300 gna however, the saturated thickness of the alluvial jeposits at this site is thin, and this well would probably yield no wore than $100 \mathrm{gpm}$ if pumped continuously. Surface water in the principal streans generally has a high chloride concentration at low flow stages, and it is probable that the aluvial deposits a so contain water with a nigh chloride content locally.

Water from the Dakota is locally of poor quality in Lincoln Courty. Within 5 miles of the site, much of the water has a high sodiun bicarbonate contenc. The chioride and sulfate concentrations are generally low in the southern part of the area but increase toward the north. The water may be umusable in the north and west.

Core Drilling. - The test hole (ABC No. 4) was drilled at the center of the east side of the site at a ground elevation of $1630 \mathrm{ft}$. The fornations penetrated and their depths and thicknesses, along with an idantification of the zones cased and cored, are sbown in Fig. 2.14. Again In this hole, the thickness of the Hutchinson salt was only $166 \mathrm{ft}$ (much less than expected), and the overlying formations were penetrated at slightly greater depths than anticipated. 
ORNL-DW6 72-9676

AEC HOLE NO. 4

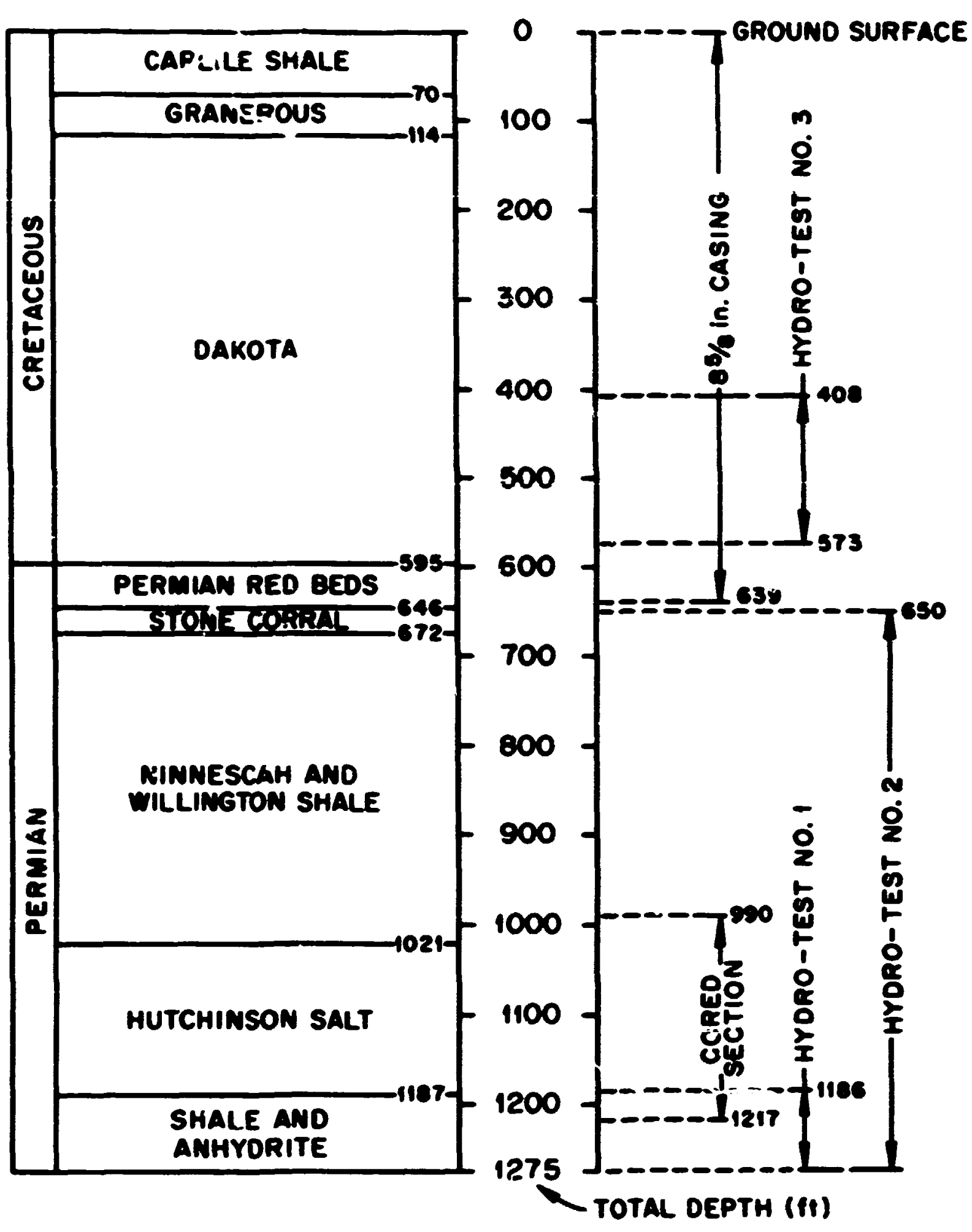

Fig. 2.14. Simpliffed Geological Iog of ABC Hole No. 4. 
Horologic Testirs. - The procedure of the hydroiogic iesting in ABC Hole Wo. 4 at Site $A_{1}$ was essentially identical to that at site $A$. The results, wich are shown in Table 2.4, indicate that both the zone below the salt ( 1186 to $1275 \mathrm{ft}$ ) and the zone imediately above the salt (650 to $1186 \mathrm{ft}$ by difference) are very tifht and have extremely low permeabilities. The purping test results for the Lower Cretaceous rocks inaicate that this well should yieid about 250 gra of water if pumed at its aximu capacity. This production is adequate onij for stack or lanestla use and is about the quantity expected in this area.

Selt Core Bramination. - The salt in ABC Hole Ho. 4 (see Fig. 2.14) $i: 3$ also typical of the Hutchinson. Correlasion of the core and 108 with logs from a single existing well in the area is o00d, and continuity of afior salt and anhydrite units within the salt section is to be expected. Both upper and lower salt contacts were recovered intact and unbroken. The loss of salt at the top of the section is marked by an unconformity within the salt section itself and by minor solution breccia within the overiying anhydrite-shale sequence. Overlying beds ar borizontal within 2 ft of the top of the salt section. There is no evidence of dissolutioning by recent ground-water activity.

Only two zones vere identified as being of sufficient thickness and quality to be of potential interest for waste disposal operations - one at a depth of 1073 to $1093 \mathrm{ft}$ and the other at 1096 to $1118 \mathrm{ft}$. Both 0: these zones include sections of poor-quality salt.

Site $B_{1}$. - Site $D_{1}$ is located in soutin-central wichita county and includes the SE 1/4 Sec. 22, S. 1/2 Sec. 2\%, all of Sec. 26 , and the $\exists$. $1 / 2$ Sec. 27, T. 19S., R. 37\%.

Topographic, Surface Geologic, and Cultural Features. - The area surrounding the site is drained by White Woman Creek and Sa-d Creek, wich is a tribuicry of white loman Creek. Nither of these streans flows except for short periods folloring very heavy precipitation. White Woman Creek Nows into the Scott besin or the Scott-Finney depression and has no surface cosnection with trunk streans in this part of Kansas. 
Topograpicaily the ar consists of relatively ilat, high upland with a gentle eastwari siope. The area also has a gentle slope toward the grincipal stroams and may cobe gently filing near the atreams. The :pland area is underiein by 20 to $30 \mathrm{ft}$ of loess, which thins to zero near the vaileys of white Woman and Send creeks. Fise Ogallale formation, which erops out only in the valieys of these creeks, underifes the loess. The average thickness of the Ogallala within 5 miles of the site is sbout 80

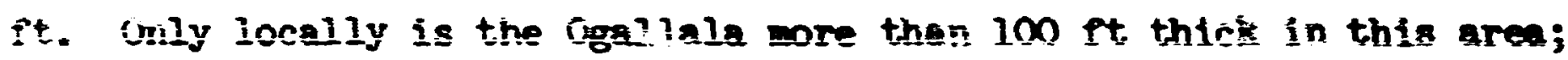
however, the formation thickens considerably toward the west and mrth, well verond the site. In the valley arees it thins to less than 50 it losally. The Ogallale overlies the Niobrara chalk of Uyer Cretaceons age, which is about $210 \mathrm{ft}$ thick. Several hundred feet of the Hiobrara was eroded before deposition of the Ogallala. The rock units below the Hotrara and above the Horrison Porietion and their thicknesses are: Carlilie shale, $240 \mathrm{ft}$; Greenhorn limestone, $110 \mathrm{ft}$; Graneros shale, 55 $f_{i}$; and the Lower Cretaceous Dakota formation, Kiowa shale, and Chejeme sandstone with a combined thickness of $360 \mathrm{ft}$.

A graveled road runs north-south through the site. To tuildings, power lines, or sescunication lines are present on the site. 10 -in. high-pressure natural gas line, owned by the Kansas-hebraska Futurai Ges Company, rins in a northeest-southiest direction about 2 miles south of the site. A three-phase porrer line runs east-rest $1 / 2$ mile north of the site, and adaitional single-phase and three-phase lines serve other parts of the general area. Commication lines within the 5-alle radius are all of the overhead type.

Hydrology. - One of the principal criteria considered in choosing this area for study was the general lack of large supplies of ground water; however, this area is well supplied with water for stock and domestic purposes, and several small irrigation wells are operated within a radius of 5 miles. An irrigation well 0.5 wile north of the site boundary has 2 reported yield from the Ogallala formation of about 395 gpa. A well located 2 miles southeast of the site ylelds $90 \mathrm{gFm}$, and two wells located approximately 2 miles west of the site each yield about 160 spa. In irrigation weils are in operation (except the one well wentioned above) 
south ond east of this site, although there are nurersus wells, all of which ditain sater fro the Ogalinla formation, toward the north and west. Yields range from about 100 to about $1000 \mathrm{gpm}$. Only the lower part of the Ogallala is saturated in this srea: which accounts for the ise yield of wells. At the weil just north of the site, the denth to water before pinging commenced was about $94 \mathrm{ft}$. However, in early 107\%, the vater levei was approxdmately $104 \mathrm{ft}$ (beion land surface). It is obricus that the level had decreased about 10 ft (or about $25 \%$ of the saturated thickness) after instaliation of the weil. A corresporiding decresuse if Field from this wil probably occurred during this period. There has been ccnsiderable lovering of the vater level further to the north of the site, and yisids are reported to have decreased.

Core Drilling. - The test hole (ABC No. 5) was drilled at the northwest corner of the site at a ground elevation of $3337 \mathrm{ft}$. The formations penetrated and their depths and thicknesses are shown in Fig. 2.15. The position of the Blaine salt in the permian section relative to the hutchinson salt can be seen by comprison with Fig. 2.14. In this case, the various formations were approximately at the depths expected, based on correlations with geophysical iogs fron oil wells thinly scattervd throughout the area. The sections of this hole tinat were cased and those that were cored are also show in Fig. 2.15.

All three of the holes ( $A B C$ Fo. 3, ABC No. 4, and $A B C$ No. 5) drilled at the three potential sites were plugged as socn as thating was capleted. The plugging procedure, ihich was the same in each case, was to set a Halliburton E-Z plug at the bottco of the 8-5/8-in. casing, fill the casing with $6 \%$ gel cewent, and squeeze with a standing pressure of 400 psi.

Hydrologic Testing. - The results of the hydrologic testing program performed in AEC Hole Ho. 5 at Site $D_{1}$ are given in Table ?.4. The results of test 1 (depth, 1950 to $2150 \mathrm{ft}$ ) indicate that the zone inediately below the salt is tight and has a very low permeability. Test 2 (depth, 1214 tc $1950 \mathrm{ft}$ by difference) indicates that the formations imediately overlying the sait accepted infer:-ed water at a significant rate, that is, about $5.4 \mathrm{gph}$. Becalive two sandstone sections 
Onxe-ours rz-soste al

AEC HOLE NO. 5

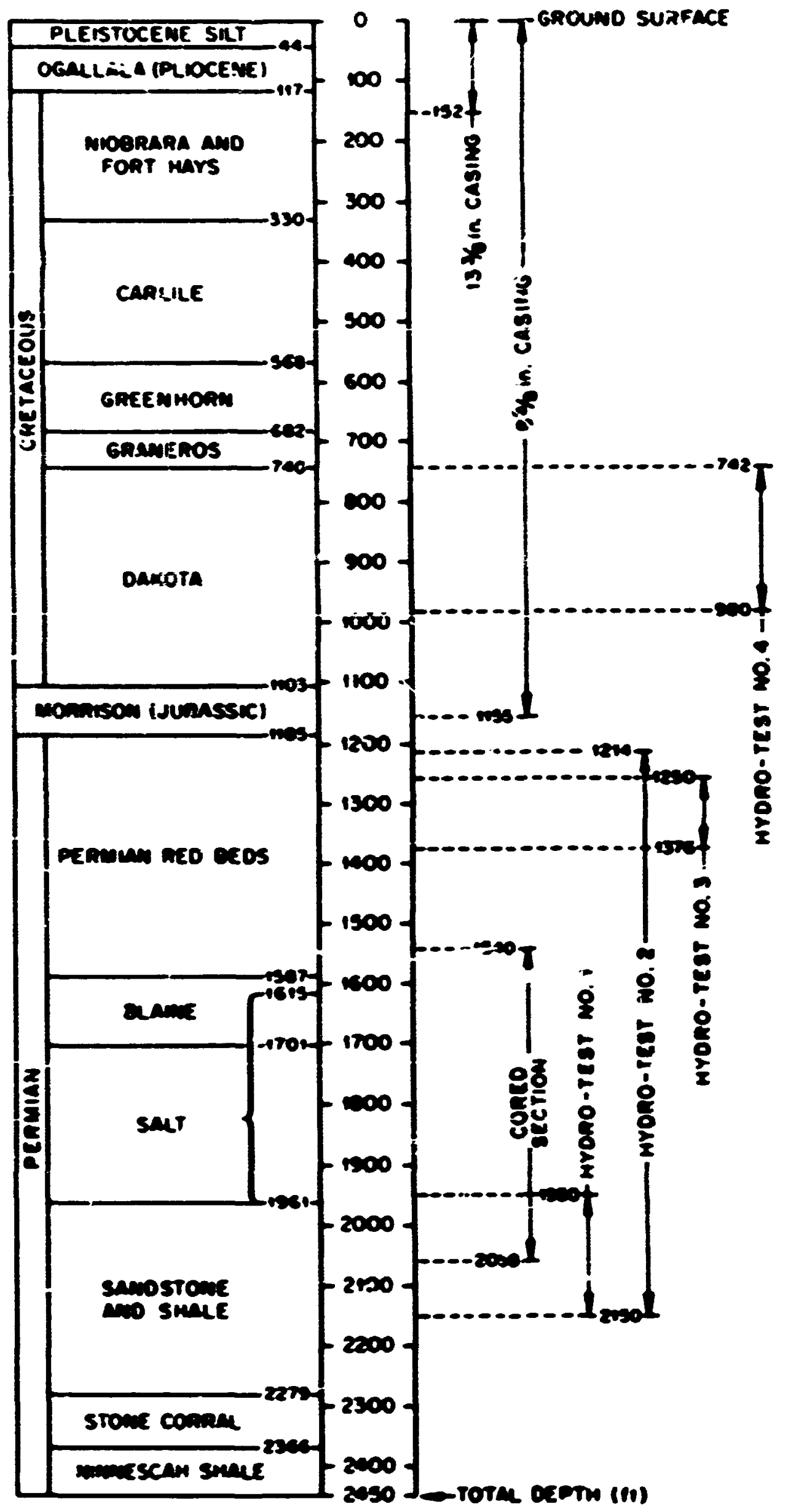

Fig. 2.15. Siplified Geological log of Nx Bole to. 5. 
(vipger, $133 \%$ to $131.6 \mathrm{ft}$; laver. 15.0 to $1570 \mathrm{ft}$ ) had been identified within the zone isolsted for test 2 , an effort was made to isolate and test one of them. Tils was accomplished in test 3 , in which the upper sandstone was straddled with packers located at depths of 1259 and $1376 \mathrm{ft}$. This upper sandstore would not accept water during the short test; therefore, it is deduced that the transmissivity indicated in test 2 was mostly in the sandstone lying imediately above the Biaine aningarite (se.e Fiz. 2.15).

The purping test of the Dakota formation in this vell (test 4) was inconclusive since it was not possible to pirg the well continususly (wth the purp available) witbout excessive drandown. It is possible that drilling Ruids had danaged the formations, thereby precluding a valid test. The results given in Table 2.4 represent extrapolations of these "siug" puping tests.

At this site, efforts were also made ro test the ogallala fornation, wich is the principal aquifer in the area. Horever, this test was also inconclusive, and no results can be given. It is believed that an inappropriate developent technique led to a partial plugging of the screen. It should be noted that an irrigation weis in this forsation located only $1 / 2$ ale distant has a reported yield of $390 \mathrm{spm}$.

Salt Core Bxoninetion. - The Biaine salt sequence contrasts stroegly with the sutchinson salt both in sharecter and guality. The formation is essentially ansive throughout and (except for sone tinick shales) banding and "fine atratigraphy" such as exhsbited by the Futchinson are nonexistent. The overall clay content is estinated to be $20 \%$, with nay large beds exceeding this value. The clay is mostly bright red and, wereas sane of it is intracrystellibe, nost of it forns - Entrix around the well-developed salt crystals, which are often $1 / 2$ in. in size. Because of this high overall. clas content and the prucity of sections with lon clay costent, units oi potential interest for vaste dispoesl could not be identified.

The exdstence and characteristics of this salt farmetion were known ouly by inference from ofl fleld geophrsical loge prifor to the drilling 
of AEC Hole No. 5. Therefore, it is not surprising that the characteristics of the salt were considerably different from those expected. From a scientific viewpoint, this hole was, by far, the most interesting of the three. This is further illustrated by the recovery of cores of a red sandstone containing well-sorted quartz sand grains cemented solely by salt (halite). The cleavage planes of large salt crystals (2 in.) forming the matrix could be seen on fracture surfaces. Such rock, of course, could not exist at the surface since it completely disaggregates when the salt is dissolved. As far as can be determined, this type of rock is unnamed and has never been described in the literature.

Summary and Evaluation. - Based on the information collected in the investigations of these three sites, the following conclusions have been reached.

i. Site I7 in Wichite County appears to be unsuitable for further consideration as a potential waste disposal site. The reasons for this conclusion are basad primarily on exmination of the core and can be summarized as follows:

(1) Overall high clay content.

(2) Paucity of sections with low clay content.

(3) Suspected lack of lateral continuity of the units.

(4) Possible hyarologic problems at the Blaine anhydrite contact and the important Ozallala aquifer.

(5) The possibility of severe stmuctural and support difficulties expected to be encountered as the result of the clay being deposited as a micilx around individual salt crystals. Inis problem would te further amplified as the depth increased.

The fifth reason is perhaps the most important one.

2. Both Site $A$ and Site $A_{1}$ are suitable for further consideration in spite of the fact that the crerall thickness of the salt formation is less than desired. This lack of desired thickness may necessitate a recuced thermal loading in order to restrict the thermal environment 
Imposed upon the overlying shales and would have to be examined closely in the analysis of the long-term integrity of containment of the wastes; however, it should not disqualify these sites at this time. The two sites are approximately equivalent $i_{i}$ most respects, except that Site $A$ appears to have a slightly more satisfactory high-quality salt zone for mining operations than toes Site $A_{1}$. On the other hand, Site A aprears to have slightly grescer ground-water supplies than does site $A_{1}$. 


\subsection{Geological Alternatives Study}

In addition in the previously desurived explorations ir. Kansas, a fairly extensive and broedly based series of studies was undertaken to examine geoiogical formations outside Kansas which appeared promising as alternatives for the location of a pilot-plant radioactive waste repository. These studies covered bedded salt deposits in other parts of the country and also included salt domes and ant.clines, argillaceous formations, and some specific mines previcusly proposed as possible sites.

The preliminary survey of alternatives was not carried out in the detail of the Kansas investigations. All of the information collected vas obtained from published or file sources and did not involve the generation of new data. Horrever, the study was desigmed to uncover as nam alternatives as possible and identify those which seened nost pronising for further study within the confines of the present concept of the repository.

The overall etjectives of this investigation were: (1) to provide a review of the potintial geologic alternatives, including background insurmation, as part of a conpehensive evaluation of alternative waste management strategies and for use in documents supporting a pilot plent repository, such us the Burlronental Inpact Statement, P8AR, etc.: (2) to identify prodising speciflc locations were pllot plant facilities could be constructed in the near future; and (3) te confirm that the disposal forestion ultimately selected is not caly acceptable but also one of the best possible solutions.

The basic requiresent of the dispoinal formation is that it wat be capable of safely containing the radiosctive naterials until redioactive decay processes have reduced the activity io ronhazardous levals. The critical mochanism for the diopersal of activity into the emiroment is leaching and transport by ground water; therefore the dioposal schene mast ensure conplete isolation of the radioactive vastes from sirculating ground water. Although many geologic envirownents are characterized by the atsence of circulating ground water, it will be necessary to ensure that this condition w11l be preserved for geologically significant time periods. Cossequently, the disposer. farmation must be not only impermeable 
but also sufficientiy plastic to close openings and heal any possible Practures.

Geologic evidence shows thut all rock types can be deformed plastically under the appropriate conditions of temperature and conifining pressures. However, only a linited miber exhibit this characteristic to a sufficient degree under conditions likely to be encountered in practical waste disposal operations. Of the geologic materials meeting tinis requirenent, rock salt is the nost indely avaliable. In view of this, the principal ephasis of the present study has been focused on certain of the salt äeposits of the continental United States, specifically the salt formations of:

(1) The portion of the Pernian basin found in southesstern lew Next:co.

(2) The Salina basin of Michigan.

(3) The Hilistor basin.

(4) The Supad salt basin and Iuke soit body in Arizona.

(5) The Gulf Cosst salt dowe regicn.

(6) The Paradox basin of Colorado and Utah.

It has also been suggested that, under ceriain favorable sonditions, selested argillaceous sedisents my behave plastically and display other suitable characteristics for waste disposal. Thus a nation-wide screening survey of shale formations as an alternative tc salt deposits vas included in the investigation.

In addition, three specific si'ses in celcareous fornations were excained, in spite of the generally unfavorable properties of these geologic materials.

Pinally, one special non-site-specific study is included here because of its direct relevance to the question of site sultability. This study concerne the natural dissolution and stability of silt in the Pernitan basin as a whole.

\subsubsection{Selt Deves and Anticlines}

large masses of pure halite have been brought to shallw depth by plastic deformation in many existing salt structures. Soveral features related to the genesis of diapiric structures raise proilens with ragard 
to demonstrating the suitability of a diven structure as a site for a radioactive waste repository.

The principal considerations are:

1. Salt dones tend to be irregularly sheged. Ic encure adequate separation of any excaration from the margin of the structure, the boundaries of the alt mass need to be delinented ith great precision.

2. Salt dones and anticlines reoult from the upinard nigration of large voluas of salt fron deeply burled source beds. This upirard afiration, or uplift, takes place at the rate of only a few allinetere per year, and sone domas are probably still rising. 52 In evaluating a specific done or anticline, it would be necessary to domonstrate that the dome or anticling is not currently active, that refurenated novenent is not foreseeable, and tiint residual stress concentrations from part novenent (which would intarfere with the excavation or the progranad closure of the aine) do not exist.

3. Becanse they intrude throuch ore-1jing sedinmts, danes are not protected from dissolution by around water circulating in overiving and adjecent sedisonts. Far this reason, adequate imvestigntion of the characteristics of cround-rater now and of pusstble diseolution rates would be required sefore a particular structure could be considared for disposel.

4. It would be nocessary to daconstrate that the ealt structure has the stability required to 1solate the vaste from the blopphere for bundreds of thousends of years; and that the relisbility of contalnent would not be reduced by the temperature increase due to geveretion of doces beat.

Gulf Const Rerdon (R. E. Anderson,"D. B. Barele*). - The Cule conet gait-dows province cen be divided into five basins. Flowre 2.16 shore the location of these basins and the aseociated dans. (263 on shore onfy.). In order to narror the fleid to a sull group with potontial autability, rany dowes cen be elininatec on the binis of excessive depth and precent usege. Table 2.5 shows the muber of refected danas, $a$ woll as the miner of poicutial doms rematning for each besin.

\footnotetext{
U.8. Geologdenl sarng.
} 


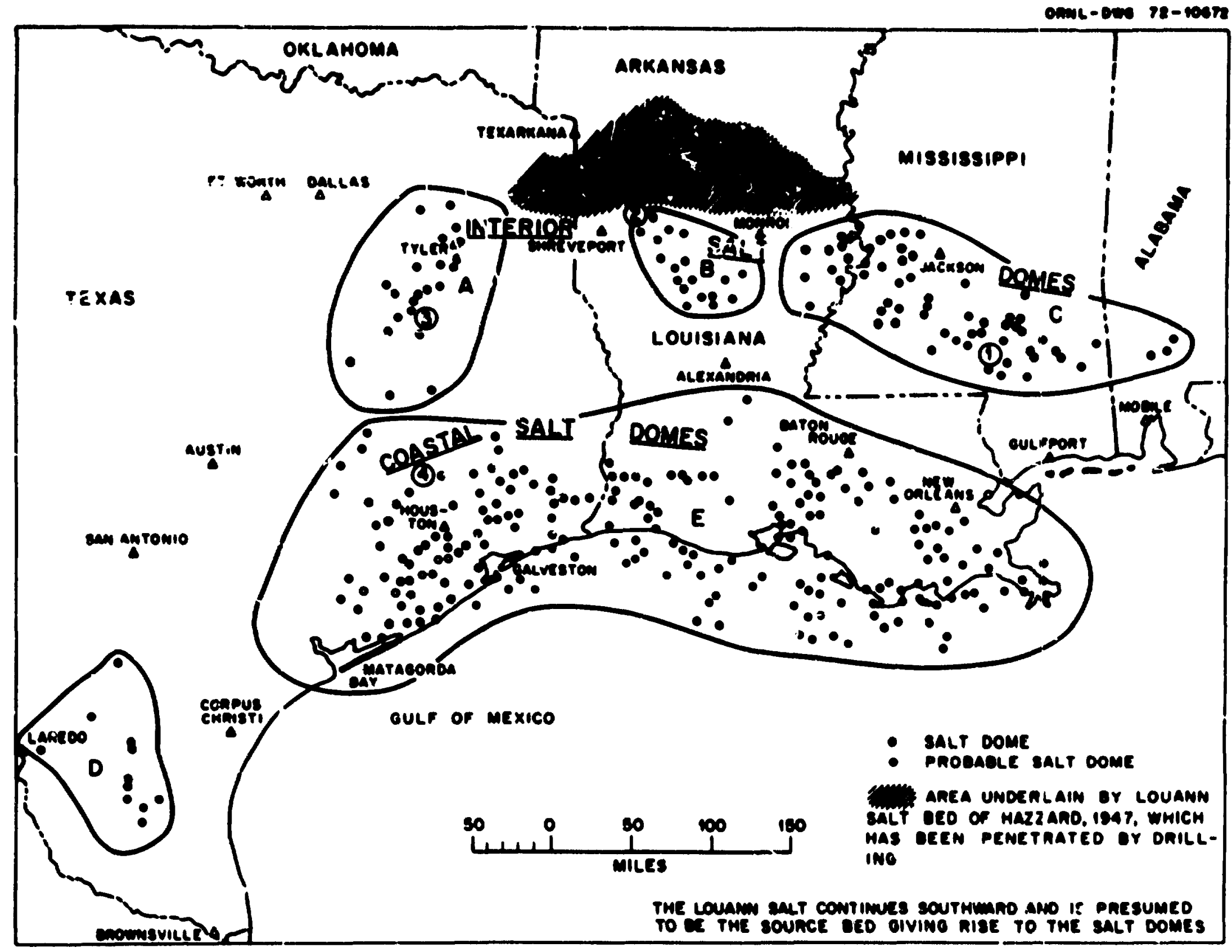

Fig. 2.16. Index Map of Gulf Cloast Provirce, Showing Salt-done Basins. $A=$ northeast Iexas basin; $B=$ north Loulsiana basin; $C=$ MAssissippi basin; $D=$ south Texas basin; $E$ = south Joulsiana basin; $I$ = Tatum dome; $a$ = Vacherie dome; 3 = Palestine dome; $4=$ Hockley dome. (After W. G. Plerce and $\mathrm{E}$. I. Rich, U.S.G.S. Bulletin I148, PJ.ate 4, 196:2) 
Table 2.5. Mumber of Rejected and Potential Salt Domes in Various Basins of the Gulf Coast Province, and Basis for Rejection

\begin{tabular}{|c|c|c|c|c|c|c|c|c|}
\hline \multirow[b]{2}{*}{$\begin{array}{l}\text { Salt-dome } \\
\text { Subpr-ovince }\end{array}$} & \multirow[b]{2}{*}{$\begin{array}{l}\text { Salt-dome } \\
\text { Basin }\end{array}$} & \multicolumn{5}{|c|}{ Bes1s for Rejection } & \multirow[b]{2}{*}{$\begin{array}{l}\text { Total } \\
\text { Rejected }\end{array}$} & \multirow[b]{2}{*}{$\begin{array}{l}\text { Potential } \\
\text { Domes }\end{array}$} \\
\hline & & Depth & $\begin{array}{c}\text { Multiple } \\
\text { Usage }\end{array}$ & $\begin{array}{l}\text { Petroleum } \\
\text { Production }\end{array}$ & $\begin{array}{c}\text { Ges } \\
\text { Production }\end{array}$ & $\begin{array}{c}\text { Salt } \\
\text { Production }\end{array}$ & & \\
\hline \multirow[t]{3}{*}{ Interior } & $\begin{array}{l}\text { Northeast } \\
\text { Texas }\end{array}$ & 6 & 0 & 3 & 3 & 1 & 13 & 7 \\
\hline & $\begin{array}{l}\text { Northern } \\
\text { Louislana }\end{array}$ & 6 & 0 & 1 & 4 & 0 & 11 & 8 \\
\hline & MSs1ssippi & 60 & 0 & 0 & 2 & 1 & 63 & 14 \\
\hline \multirow[t]{3}{*}{ Coastal } & $\begin{array}{l}\text { Southern } \\
\text { Texas }\end{array}$ & 3 & 0 & $?$ & 0 & 1 & 5 & 1 \\
\hline & $\begin{array}{l}\text { Southern } \\
\text { Loulsiana }\end{array}$ & 73 & 30 & 29 & 2 & 1 & 135 & 6 \\
\hline & Total & 148 & 30 & 34 & 11 & 4 & 227 & 36 \\
\hline
\end{tabular}

Many of the domes rejected on the basis of depth also have active ofl and gas production. 
Additionai domes could probsbly be eliminated on the basis o:: such factors as size, potential flood hazard, ground-water problens, land use, etc. Available data were compiled on the 36 potentially sujinile domes. It appears that information providing a basis for an adequately supported evaluation of the salt structures for siting a waste repository exists for only 4 of the 36 shallow unused domes: Tatum, in lississippi; Vacherie, in northern Louisiana; Palestine, in northeastern Texas; and Hocicley, about 30 miles northwest of Houston. Some facts pertaining to these four domes are tabulated in Taole 2.6. Their locations are shown in Fig. 2.16.

One of the major informaiion deficiencies relates to the inability to estimate size and shape of domes at particular depths. The upper surfaces of many well-known domes are irregular, which suggests that the same condition may be revealed for the unused potential aomes, for which data are nresently scarce, if more extensive irvestigations are undertaken. Because the iups of many of these dones are quite near $2000 \mathrm{ft}$ of depth, the possibility of being forced to much greater depths by irregularities in the upper surface becomes critical.

Thus far, studies of the Gulf Crast Region indicate that the intirior salt-dome province is more suitable than the coastal ace, based on the folloring considerations.

1. Many interior salt domes have probably been structurally stable siluce late Tertiary, based os, the urjisturbed conditions of bla keting sediments, whereas coastal domes are probably younger and, even if they are not undergoing active diapirism, are certainly in $\varepsilon$ more structurally unstable environment. 58

2. In northern Louisiana and Mssissippi, water in wells located dow the hydrologic gradient from salt domes does not tend to be more saline than in other wells. Deformed strata above and around some domes are elevated to levels where increased recharge has produced flushing of some aquifers to deeper levels than in the surrounding undeformed areas. These relationshipe suggest, either that dissolution of salt is not occurring or that, if it is, the rate is below the detection capabilities of the sampling system. 
Tablo 2.6. Date sumary for selected salt Dasas in tho oulf Coest Province

\begin{tabular}{|c|c|c|c|c|}
\hline & Tatoun & Vacherie & Paleatine & Hockley \\
\hline Dopth to cep rock, it & $530-675$ & 658 & 120 & 74 \\
\hline Dopth to ealt, st & $1460-1605$ & $m$ & 122 & 2010 \\
\hline Dienotor at $500 \mathrm{Nt}$, It & $\mathbf{0}$ & 0 & $\sim 3000$ & 0 \\
\hline DHenter at $2000 \mathrm{ft}$, It & 4000 & 4300 & $\sim 7500$ & $>23,000$ \\
\hline 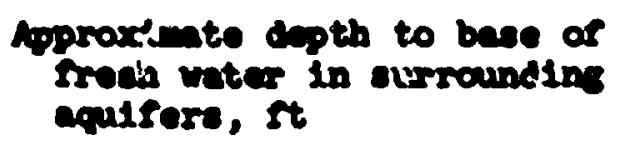 & 1500 & $400-500$ & 1400 & $1800-2000$ \\
\hline nearest population conter & $\begin{array}{l}\text { Purvis, mas., } \\
8 \text { atios } E\end{array}$ & $\begin{array}{l}\text { Gibeland, } 20 \text { miles } \mathrm{ME} ; \\
\text { Minden, } 12 \text { atlos } \mathrm{NW}\end{array}$ & Palestine, 4.7 miles $\mathrm{KR}$ & $\begin{array}{l}\text { Hockley, } 4 \text { miles } N_{i} \\
\text { Central Houston, } 31 \text { m1 les } 82\end{array}$ \\
\hline Dretence to rasl & $\begin{array}{l}\text { Purvis, Mes., } \\
8 \text { anles } 5\end{array}$ & $\begin{array}{c}3-1 / 2 \text { miles } W, \\
6 \text { atles } n\end{array}$ & $2-1 / 2$ miles 82 & 4 miles N \\
\hline Dsistiace to histown & 2 nd100 $n$ and & 6 m:100 $\mathrm{E}$ & 2 miles $8 E$ & $4 \operatorname{miles} N$ \\
\hline Earost ourfece-water body & $\begin{array}{l}\text { Panrl Raver, } \\
13 \text { adien W }\end{array}$ & $\begin{array}{l}\text { L. Bletinean, } 6 \text { niles } W_{\text {; }} \\
\text { Diahawy Creak crosses } \\
\text { etructure }\end{array}$ & $\begin{array}{l}\text { ondl, ahallow saline } \\
\text { leke on dang; Trinity } \\
\text { River, } 10 \text { miles } 8 W\end{array}$ & Brazos River, 10 miles W \\
\hline Qullety of enrrece drainase & $\operatorname{cood}$ & Falr to good & Cood & acod \\
\hline $\begin{array}{l}\text { Iopogrephic reller over } \\
\text { etrueture, rt/ed }\end{array}$ & 100 & 50 & 80 & Almost level \\
\hline mber of wells to selt & $\begin{array}{l}16+\text { odmon-shot } \\
\text { chates }\end{array}$ & 6 & 26 & Ansorous \\
\hline S-atio redise & $>39$ & $>18$ & $12+\underset{(-50)}{\operatorname{Lape}}$ Leke $\mathrm{rleld}$ & $>20$ \\
\hline 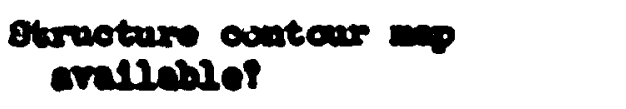 & Yees & Yos & Yce & Yoer \\
\hline
\end{tabular}

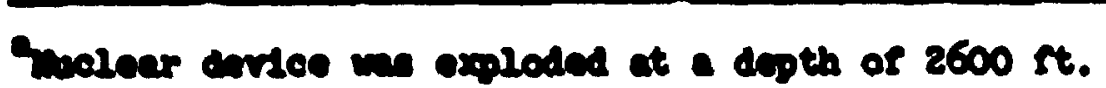


3. The shallow domes in the coastal subprovince are more extensively used by the petroleum industry than those in the interior.

Paradox Basin, Utah and Colorado (R. J. Hite, S. W. Lahman ${ }^{*}$ ). - The Paradox basin iff southeast Utah and scuthwest Coloradis contains a series of northwest-trending salt anticlines wich reach within 500 to $3000 \mathrm{ft}$ of the surface along the nurtheas: edge of the kasin. Figure 2.17, an index map of the Paradox basin, shows the location of various salt anticilines. The totai area underiain oy sait is approximateiy ic,000 square miles. The evaporite deposits of the basin occur in the Paradax member of the Hermosa formation of kiddle Pennsylvanion age. 59

The salt anticlines are of tur types: tlose in wish the salt units are conformable with orerlying rocks, and those in which they are unconformable or intrusive. The latter type is characterized by a complex salt core and the development of a cap rock. Isese capping units of supsus, dolonite, and black shale were originslly interbedded with halite, but grcund-water leaching has rewoved the more soluble salt. Estimates of average leaching rates in post-Cretaceous time are on the order of $22.4 \mathrm{ft}$ cf salt over a period of ane pillion years frou the crest of a typical anticline.

The grestest orifinal thichess of salt was deposited in a structural trough and was probably on the order of 5000 to $6000 \mathrm{ft}$; however, this thicioness has been modifled by subsequent flo age of the salt and is as great as 14,000 ft in one anticline. At their maximum development the salt deposits consist of 29 evaporite cycles, of which halite and potash merals (if present) generally form 70\%. The halite units range from a few feet to several bundred feet in thickness. The total water-inscluble content of the halite seldom exceeds 2 to $3 \%$ by weight. The relatively impermeable nonchloride units of the cycle are reasarkably persist.ent markers throughout the basin and, where penetrated in drilling, comonly produce amall flows of brine or oll and gas. Occesionally, hydrocarbon accumlations large enough for comercial pjoduction are encountered. Formation cintds are comonly under abnarally high pressure, requiring

*.3. Geological survey. 


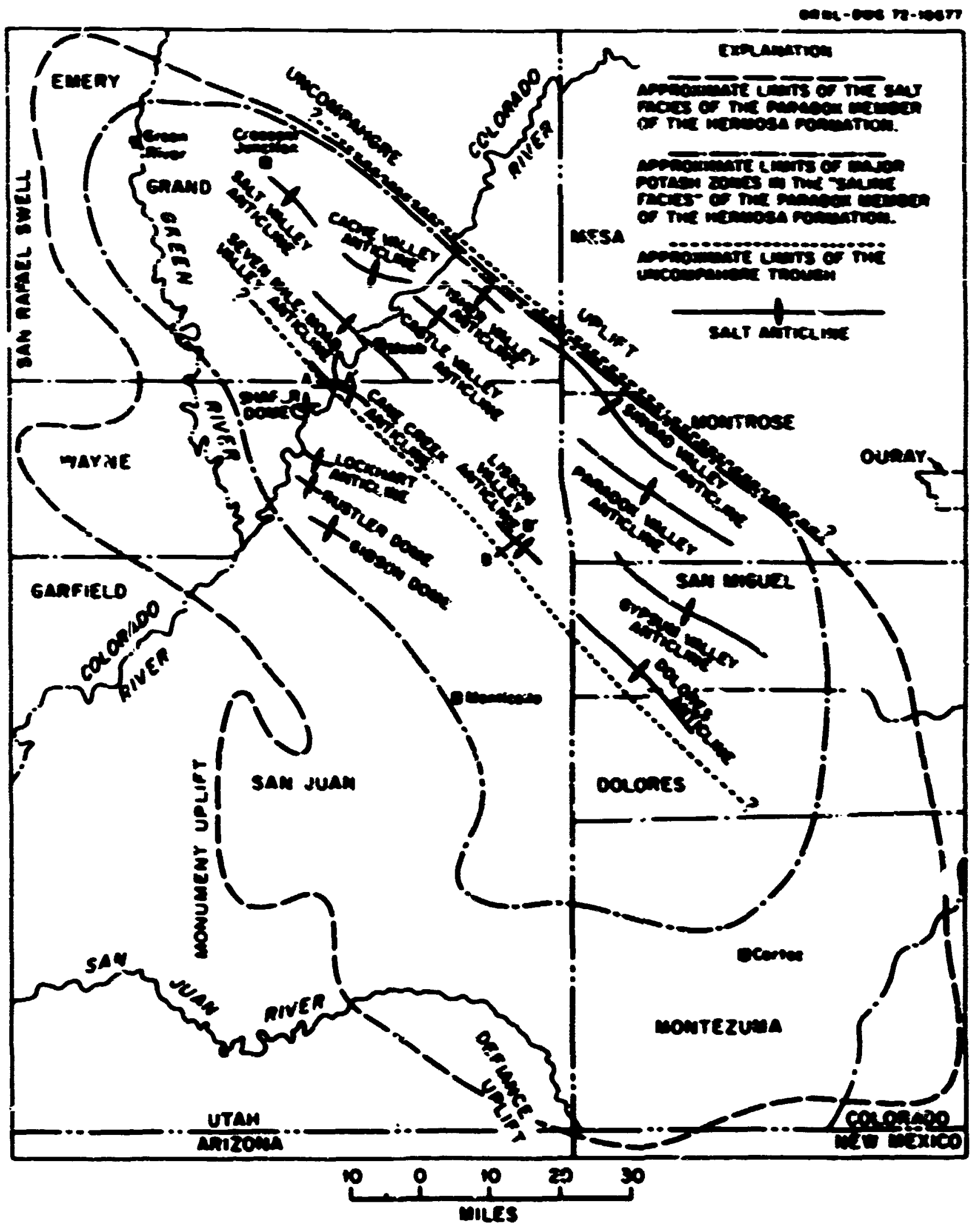

Fig. 2.17. Index Mp of Paradux Basin, Southeast Utah and Southwest Colorado. (Fron Robert J. Hite, Geological Soclety of America Special Paper 88, F18. 1, p. 322, :968) 
the use of hifh-density in driliing. Underground mining operations in these deposits require the standard safety precautions for "gassy" atnes.

The narthern end of the bas in is characterized by low population density and livestock grazinz. Industrial developent consists of uranium abes ad allis, several oil and gas flelds, and one potash wine. isuch of the area is deeply dissected by canjoas with rellef of nore than $8000 \mathrm{ft}$. Several paved higmnss and a rallroad traverse the ares; nevertheless; wach of the basin remains fairly inccessible.

\section{2.j.2 Bedded Salt Doposits}

Larbe areas of the United States are rinderlain by bedded salt. The fa:loring discussion is Iinded to selected areas of the Pernian basin, the Arlzom salt deposits, the Sulina basin, and the Hilliston basir. Particular expiasis is placed on the southeastern New Maxico portion of the Pordian tasin, were salt beds $x$ appropriate thickress, purity, and dapth ist orer fairly large areas.

Staility af Badded Salt in the Perrian Basin iG. O. Bachnan," R. B. Jotrson," F. A. Srenson" ). - The Pernian basin in the western Interior $\alpha$ : the United States is a series of sedinentary basins in with halite and sosclated salts acculated during Permian tine. The region Includes the western part of Kansas, Oclahoma, and Texas ard the eastern parts of Colorado and New Mexico.

Pallouing a lang period of relative stability in the carly Paleozoic, the region undervent considerable tectonian during late Pennsylvanian and Eurly l'ers an time. Such features as the Centrel Kansas Uplift and the central basin platform in vestern Texas and southeastern New Nexico were uplifted, wile rhick accumalions of sediments were deposited in the edjecent subsidieg basins. As the region stabilized in late Permian time, these basins vere partial'y restricted, giving rise to salt deposition. mese basins iere not conterporanecus or contimous throughout the region; as a realt, the salt units are muarous and discontionows. In general, salt deposits began earlier in the northern part of the basin (Kansas and U.S. Geological Survey. 
northern Oklahoma), with tine salt becoming progressively younger toward the south.

The reg on hes been relatively stable since the Permian, undergoing slight regional warping, one major incursion of the sea, and periods of erosion. Deep-seated faults or igneous intrusions are rare. On the other hand, subsidence and collapse of the land surface related to dissolution and other shallow processes have been commonplace in the Permian salt basin. Some dissolution and reorganization of salt deposits probably have been occurring since defosition of the salt more than 230 million years ago. However, the processes of preservation must have been dominant orer processes of removal; otherwise, the higily solubie minerals could not. have survived in bedded form throughout this great length of geologic time.

iocal subsidence features that appear to be directly related to shellow dissolutioning of salt include Clayton basin, Nash draw, and San Simor sink in southeastern New Mexico. Additional features exist in suuthwestern and central Kansas, western Oklahoma, and the Texas panhandle.

Bedded salt in the subsurface is stable only if it is protected from a continuing supply of fresh ground water. Channels that provide moverent for a continuing supply of ground water include: (I) sclution channel: opened from adjacent porous and permeable rocks, (2) fractures, snd (3) drill holes.

The presence of karst topography is a major criterion for recognizing areas in which dissolution has been active in the past. Therefore, the datiris of karst development can be a useful means for estimating the rate of dissnlution. During the present work, the Pliocene Ogallola formation was taken as a point of reference for dating the development of recent iopography. Deposition of this formation, which was widespread in the Permian basin, began atout 12 million years ago and ceased approximatelv 5 to 7 million years thereafter. Most of the erosion and dissolutioning phenomena that are visible in the present landscape of the basin began during Ogallala time and have continued in the 5 to 7 million years that followed. 
It is estimated that salt in the southeastern New Nexico area has been dissolved laterally at the average rate of 3.5 to 4.0 wiles per million years. This conciusion is based on the following geologic assumptions :

(1) The Ogaliala formation formerly extended across the Pecos River Vailey, at least as far as the frant of the Guadalupe Mountains.

(2) The Pecos. River Valley in the vicinity of Carlsbad has been formed since Ofallaia time.

(3) The distance fram tha eastern front of the Guadalupe Nountains to the present western limit of major salt beds is about 18 to 20 miles.

(4) The Ogallala formation has been eroded, and the Permian salt has been dissolved from this area during the past 5 mijlion years.

It does not appear probable that salt extended much farther west than the front of the Guadalupe Mcuntains before Ogallala time; if the salt was iess extensive before Ogaliala time, the present stimate is conservative.

Climate is a major factor in the availability of ground water and the rate of dissolution. Climate has been varied and was subject to major fluctuations at various 1 -tervals since Ogallala time. ${ }^{\text {EO At least }}$ two major duce fields, ose of which has been active within the past 6000 to 8000 years, have occurred in the vasin since ogallala time. Also, a rorest corsred the region al out 10,000 years ago, prior to the most recent cunes. Estimates of future rates of salt dissolution include the assumpticn that climatic changes in the fuivure will be of the same order as those of the past.

Large amounts of salt are carried by present-day $;$. rers in the Permien basin. Some of this sit originates from the slow dissolution of the subsurfice salt $b$ sds. The surface drainage of one western Texas basin carries about 670 tons of sodium chloride in solution per day. If spread equally over the area being drained, this amounts to only 0.5 ft of salt sulution por thousand years. As mentioned previon'sly, the availability and rate 
of circulation of ground water are the controling factors in dissolition. The movement of ground waters in the Permian basin is relatively s?.uw, ranging from $0.015 \mathrm{ft} /$ year in the San Andres limestone (a Permian furmation) to $0.4 \mathrm{ft} /$ year $: r_{i}$ the mari-permeable Triassic rocks.

Southeastern New Mexico Area (A. L. Brokaw, , C. L. Jones, M. E. Conley, W. H. hiays ${ }^{*}$ ). - The Pernian basin in southeastern New Mexico contains extensire evaporite deposits in the appropriate thickness and depth ranges. Potash minerals have been extracted in the area for approiimateiy 50 years. The potash area is located in eastern Eddy County and western Lea County, 15 to 30 miles east-southeast of Carlsbad. Pigure 2.18 shows an index map of the area. The topography can be broken dow. into four wajor ifvisions: foothills of the Guadalupe Nountains, the high plains, isolated areas of low hills, and ridespread pediments and allivia]. planes. These topographic provinces are locally modified by coilbpse foatures. The generbl area is sparsely populated; except for wioly scattered ranch and farm dwellings, the only population centers within 20 miles are Caristad, Loving, and four other small commities.

The arsa of the potash mines includes the northern end of the Delaware basin, a late Permiar depositional trough whose edge is commonly defined as the front of the largely buried Capitan Reef. The entire sedimentary sequence includes strata from Orclovician through Quaternary age and has a total thickness in excess of $20,000 \mathrm{ft}$, with up to $23,000 \mathrm{ft}$ of Permian strata. The oldest rocks exposed in the area are of Late Permian age, but abundant information on older rocks is arailable from drilling.

Tne strata in the vicinity of the potash mines have been iectonically stable since Tertiary time and are only slightly deformed. The principal scructural wits are large-scale featires related to late Palerzoic sedimentation: the northern Delaware zasin, the shelf north and west of the basin, and the central basin platform to the east. These structures were tilted slightly eastwerd during pre-Pliocene Tertiary time, reaulting in a regional eastwart dip of from 1 to $2^{\circ}$.

*U.S. Geological Survey. 


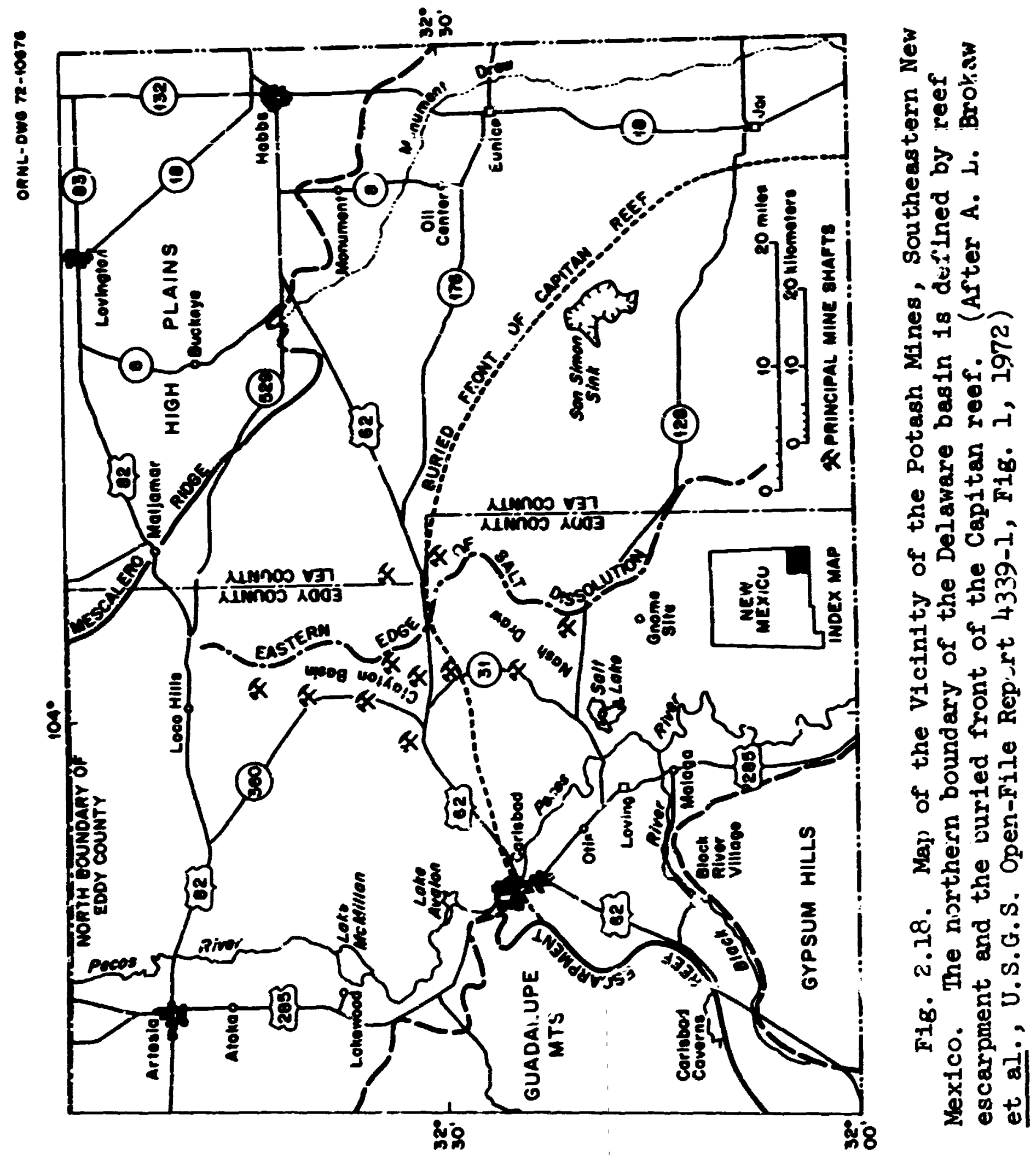


The salt deposits of the area are contained in the Late Permian Ochoan scries, wich is divisible into two parts: a thick lower section of spit-bearing evaporites including (in ascending orde.-) the Castile, Salado, and fustler formations and thinner section above composed of the Dewey Laike redbeds. 61

The Castile forsution consists largely of interlaminated gray anhydrite an'l brownish-gray limestone, but it contains a large percentage of rock salt. It has a thickness of about 1500 to 1600 ft along this southern edge of the region, thins northward to about $1000 \mathrm{ft}$ near the margin of the Deloware basin, and tongues out in the southermmost parts of the nortiwest shelf. ilj. the salt is concentrated in a thick middle member which lies 200 to $300 \mathrm{ft}$ abive the base of the fcrmation.

The Salado enrmation, the main salt-bearing luit of the area, ranges in thickness from about 1900 $\mathrm{ft}$ in the south to about $1000 \mathrm{ft}$ at the northern edge. The formation is characterized by thick persistent units of rock salt alternating with thinner units of anhydrite and polytalite. Thin seams of claystone underlie the anhydrite and polyhalite units, and a few beds of sandstone and siltstone are present at large intervals.

The Salado formation is divided into three informal units: a lorer salt member, a middle potassium-bearing member kr.om locally as the Nelintt potash zone, and an upper salt member. The three menier's are similar in most zespecis, except for the cccurrence of economical.Iv significant deposits of sylvite (KCI) and other potassium and magnesium evaporite minerals in the Ncrutt zone. ${ }^{61}$

The Rustler formation, which is the uppermost ealt-bearing unit in the Ochoan series, is 300 to $400 \mathrm{ft}$ thick in the southern part of the area and thins to about 200 to $250 \mathrm{ft}$ in the north. It is mastly anhydrite ard rock salt. Some dolomite is present in the upper and lower parts of the formation, and thin to thick units of sandstone and shale are interbedded at long to short intervals.

The Dewey Lake redberis at tine top of the Ochomseries consizt of reddish-brown siitstone and fine-grained sandstone. The formation is 250 to $550 \mathrm{ft}$ thick in the area. 
Ground-water Hydrology. - Three main hydrologic units control the ground-water hydrology of the southeastern New liexico area. These are: (I) the Pecos River, wich receives the ground-water outflow from the potash mining area; (2) the water-bearing strats overlying the Sal ado fomation; and (3) the Capitan limestone and ottar water-bearing strata underlying the salado formation. The dist-ibutiun and deveiopment of large solution features, particularly in the Mssh draw and Clayton basin sreas, exert major effect on the occurrence and movement of ground water.

The Pecos River receives nearly sll the natural discharge of ground water that moves through the rocks of the pctash minirg area. The principal places of natural ground-water inflow are at Carlsbad, where water derived from the Capitan limestone discharges to the river or to the alluvium bordering the river, and near Nalaga bend, where highly mineralized mater is discharged from the Ruscler formation to the river. Nost of the ground-water dischurge from the mining aree occurs in the reach of the river near Yalaga bend.

The main aquifers or water-yieldins units overlying the salado formation are the Culebra dolcmite member and basal solution breccia zone of the pustler formation, the Sants Rosa sandstone, and the alluvium. The Culebra dolomite member, which ocurs throughout much of the area, is the main source of water tapped by stock wells. The basal solution breccis zone of the Rustler formation, often referred to as the "brine aquifer," is the unit that, is most significant in relation to the dissolution of halite in the unper part of the Salado formation. The approximate eastern edge of evaporite dissolution and removal by ground water in eastern Eddy Connty is indicated in Fig, 2.18.

The formations above the Salsio seein iv be connected rydrologicaliy and can be treatca as a single miltipile aquifer system. Tie degree of development $a r^{2}$ the aquifar system is nut known and $c$ unnot be determined frow the exist.ng hydrologic information, al though the levels of water standing in wells are sufficiently uniform that potentiometric and woter table cuniours can be constructed ihroughout the area. Dissclutior 
activity and associated collapse, subsidence, and fracturing have increased the overall permeability of the rocks and have enhanced the interformational movement of water in the aquifer system. In the mining area, the aquifer system seems to be best developed between the wateryielding units of the Rustler and between the Rustler and Gatuna formations.

Ground water in the formations above the Salacio moves generally southwarj aild southrestward across the potash mining area toward the Pacis River. Allthough the total amoun: of ground water discharging to the Pecos River is not know with any degree of conridence, it has been estimated that $200 \mathrm{gpm}$ enter the river from the basal sclution breccia zone near Miacia bend. $6 ?$

The potentiometric and water table contours outline a series of ground-water ridges and troughs, which are imposed on the regional southward-to-southwestward pattern of ground-water movement. A large southwestward plunging, grousin-water trough extends from Malaga bend northeastward, roughly through Nish draw to beyond the mining area. Another much smailer trough is located east and southeast of the Project Gnome site.

The intergranular porosity and permeability of the Salado rumation range from low to virtually nil. Locally, fractures and solution openings impart a spotty formaticnal permeability. In tive potash mining area, the Salado formation is dry except for small pockets of brine or brine and gas that have becn encountered occasionally during mining and test drilling, and for water present in the leached zone developed at the top of the formation.

The Paleozoic sedimentary rocks underlying the Salado formation contain highly saline water and are under artesian pressure. These rocks are not exposed in the potash mining area but lie deeply buried in the subsurface throughout much of southeastern New Mexico and westarn Texas. In the potash mining area, the elevation of the potenticmetric surfaces of different zones of these rocks ranges from a few feet to a hundred feet above or below the land surface. 
Arizona Salt Deposits (J. W. Wtton ${ }^{*}$ ). - In Arizona, salt is found in two completely different physiographic provinces: the Coior ado Plateau and the Basin and Range Provinca.

Supai Salt Basin, Arizona. - The Supai sait basin embraces an ares of approximately 2300 square miles or the Colorado Plateau in eastcentral Arizona. Paleozoic stra'sa exposed along the Kogollon rim, a praninent escarpment marking the southern margin of the platean proper, dip ts che north and northesst at low angles to form a near dip slope that is comonly called the Vogollon slope. This topographic feature adjoins the Black Fesa basin north of Winslor and Folbrook and tise Defiance uplift to the northeast. In the intervening lower land occupited by the Nogillon slope, the Iittle Colorado River flows northwesterly between St. Johns and Holbrook. The average anmual runoff in the area ranges from less than 0.1 in. to nore than 5 in.; the sienificant tributary runoff cones mainly from the Mogollan rim and mountains to the southeast. Figure 2.19 is an index nap of the arez.

Yost of the area is underlain by thick, generally inpermeable, shaly rocks of tive Chinle and Koenkopi formations of Triassic age. The Kaibab limestone and Cuconino sandstone of permian age crop out, crly in the southwestern part of Navajo County. The Ccconino is present, in the subsurface throughout the area and is the most important aquifer in the region. It is recharged primarily in the area near the Yogollon rim and discharges principally in the Holbrook-Winslow and St. Johns areas.

Solution-collapse phenomena are present in the area of the Halbrock anticline, the largest of several predominantiy northwest-trenaing iolds of early Tertiary age within the area of the Mogollon slope. Sinks and related features are the results of dissolution of Permian evaporites. The Coconino sandstone djrectly overlies the evaporite section and ascounts for the solution-collapse features.

The Supai formation, which contains the basal Permian beds, occurs only in the subsurface and consists of interbedded sandstone, siltstone,

\footnotetext{
*.S. Geological Survey.
} 
ORNL-DYO 72-10675

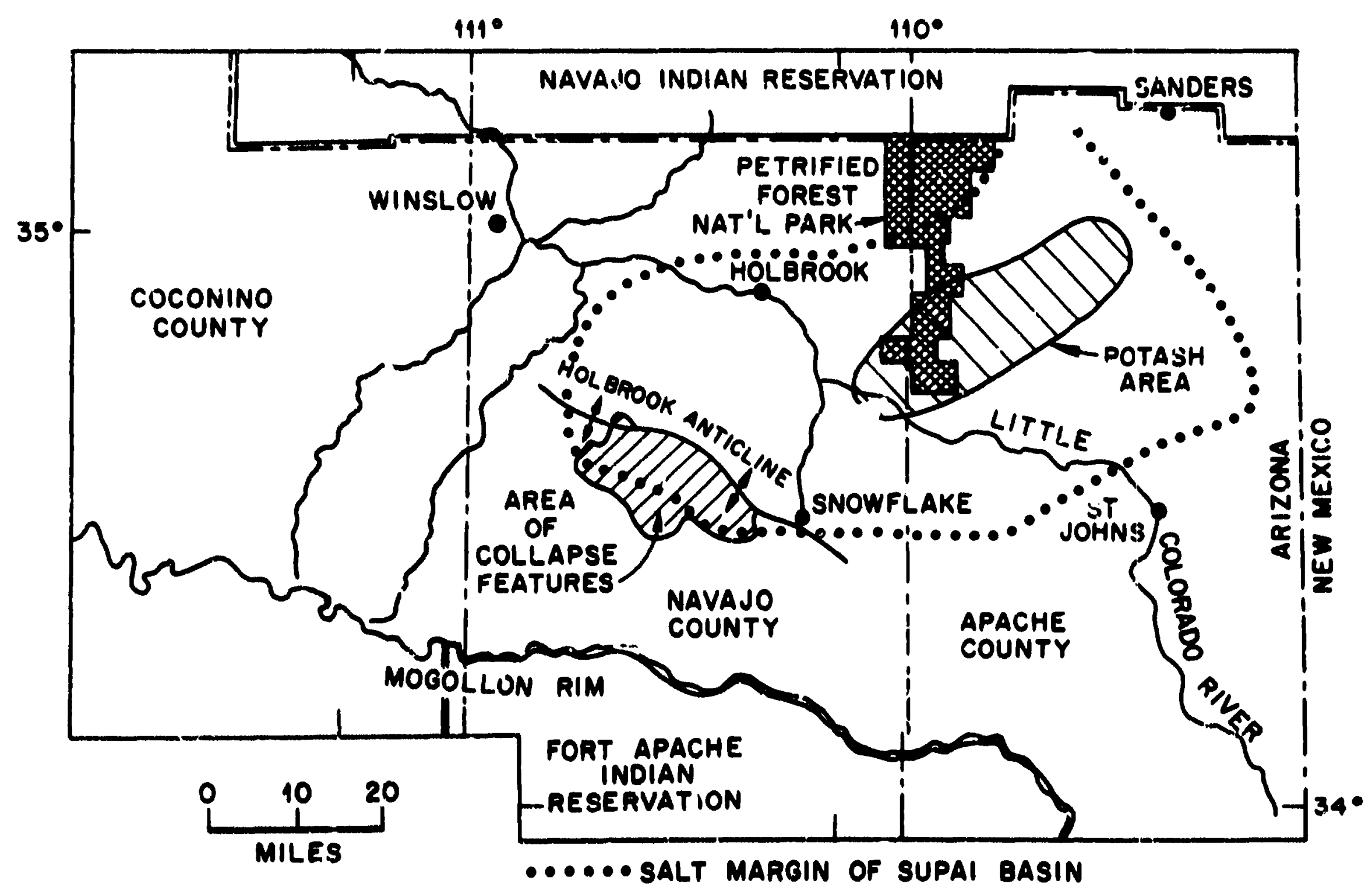

Fig. 2.19. Index Map of Supal Basin, Arizona. 
and adstare, and eveporite beds of anhydrite, Byporn, and halite. 63 It is absut 1600 ft thick near the Ar'.200na-liew Mexico state lins and thickens to more than $8500 \mathrm{ft}$ southwest of llolbrook. The frowcips? hallte leposits, sssociated with anhydrite, dolonite, and clastic redbists, occur as discontimuous units within an evaporite-bearing stratigraphic interval, 450 to $1300 \mathrm{ft}$ thick, between the Fort spache IInestone nesber of the Supai formation below and the overlying Coconino sendstone. Depths to the top of the eraporite interval, which is marked by an anhudrite-eopsum zone, range from 600 to $2500 \mathrm{ft}$; the deepest parts are in the northeastern section of the Supai basin.

Indications are that the principal concentration of haiite occurs in a zone 400 ft thisk within the upper half of the evaporite interval along a 55-ille northeast-trending belt betreen Scourllake in Iarajo Counts and Pinta dome in Apacke County. Agsregate thicknesses of as anch as 500 ft of salt have been reported, but individual beds in the basin do not exceed 160 to $200 \mathrm{ft}$. In general, salt caprises from 5 to $15 \%$ of the supas formation.

A northeast-trending petash zone under sn area of about $30 \mathrm{C}$ square niles has been ielineated bi exploration holes in the northern part of the Supai basin. The potash zone is within $150 \mathrm{ft}$ of the iop of the eraporite section, wich is marked by an anhydrite bed in most places. Depths to the potash range between 700 and $2000 \mathrm{ft}$ belos the surface, the shallower depths being to the southwest and the deeper depths to the northeast. Most of the exploratory drilling for petroleten and natural gas has been done in the vialuity of the iolbrook anticline, were drilling objectives have been the Fort Apache limestone and rocks of Pennsylvanian age and older: and northeast of Holbrook, where high concentrations of helium have been found in natural gas in the coconino sandstone and in rocks of Triassic age. The largest producine field is the Pinta dome Pield, abovt 35 miles nor theast of Holbrook.

The Supas basin is bordered on the north and south if Irdian rese:vatione and contains a national perk with:n its limite, The proximity of the Supai salt basin to the Santa Fe railroad and U.S. Highway 66 , both 
major transconcinental roites, makes tine area easily accessible. In aldition, the sparse population and Hinted agricultural developant in the general area, as well as the tectonic sishlilty, can be considered favorable characteristics.

Inke Salt Body, Arizana. - The Iuke salt body is locaitu in the Basin and Range Provinse in the vicinity of the Iuke Ar Force Base, if miles yest:-northwest of Phoenix. 64 According to published data, hallte

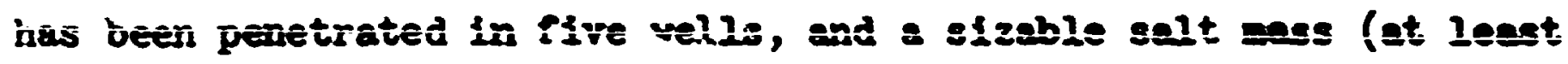
15 cubic miles, and possibly as wch as 30 cubic alles) has seen inferred from a large negative gravity ancaly. Interpretation of the gravits data indicates that the salt mass is prismatic, extending pprodimately 6 miles in a northeast-southwest direction and 10 miles in a north-south line with its base at a depth of at least $6500 \mathrm{rt}$. Its configuratica susgests either the core of a salt structure or an undeformed vedinentary accuralation in which only the uppermist part has foured plastically. The salt is apparently oi late Cenozoic age. Iow hills in the area prc - ils result efther from plastic florage or differentiai copaction betreen the salt and surrounding sedinents.

Based on gam ray--nsutron logs, the generalized Ithology of the sal: mass between 800 and $4500 \mathrm{ft}$ is primarily very pure halite with shale interbeds underlying a 60-ft anhydrite caprock. Cevhudrologic data indicate that the upper fart of the salt mass affects the salinits of ground vater containei: in alluvial fill. The surrownding area is one of lintec agricultural use, and most of the vells are relatively shallow and used for irrigation.

Figure 2.20 shows the location of the Iuke salt body and other salt deposits in tis Basin and Range Province.

Selina Basin: Iew York, Pennsylvanie, West Virginia, Osio, and Yichigan. - Bedded salt deposfts of Jate Silurian age occur in the salina formation, which underlies portions of New York, Pennsylvania, Weat Virginia, Onio: Michigan, and southrestern Onterio. 65 Figure 2.21 is an index nex of the area, shoring the approximate extent of the Saline formation and the regional structural features associated with the salt units. The 
ORNL-DWG 72-10674

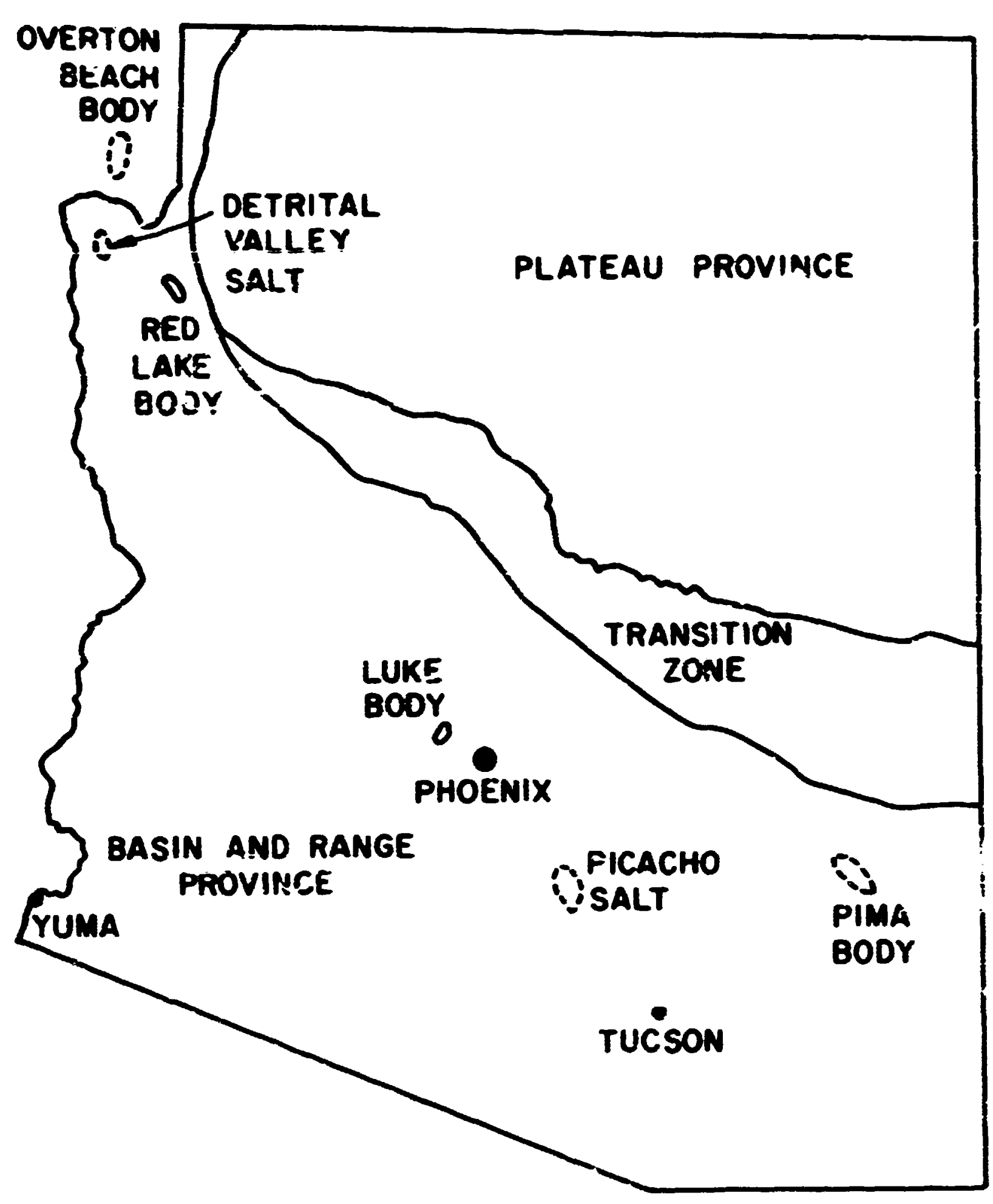

Fi8. 2.20. Nop of Arizona, Sharing Saructurel Provinces and Location of Salt Deposits of the Rasin anci Range Province. (After E. A. Koester, Arizona 011 and Gas Conservation Counission Geology Repor' Ho. I, Fig. I, p. 2, 1971) 
ORNL-OW6 72-10673

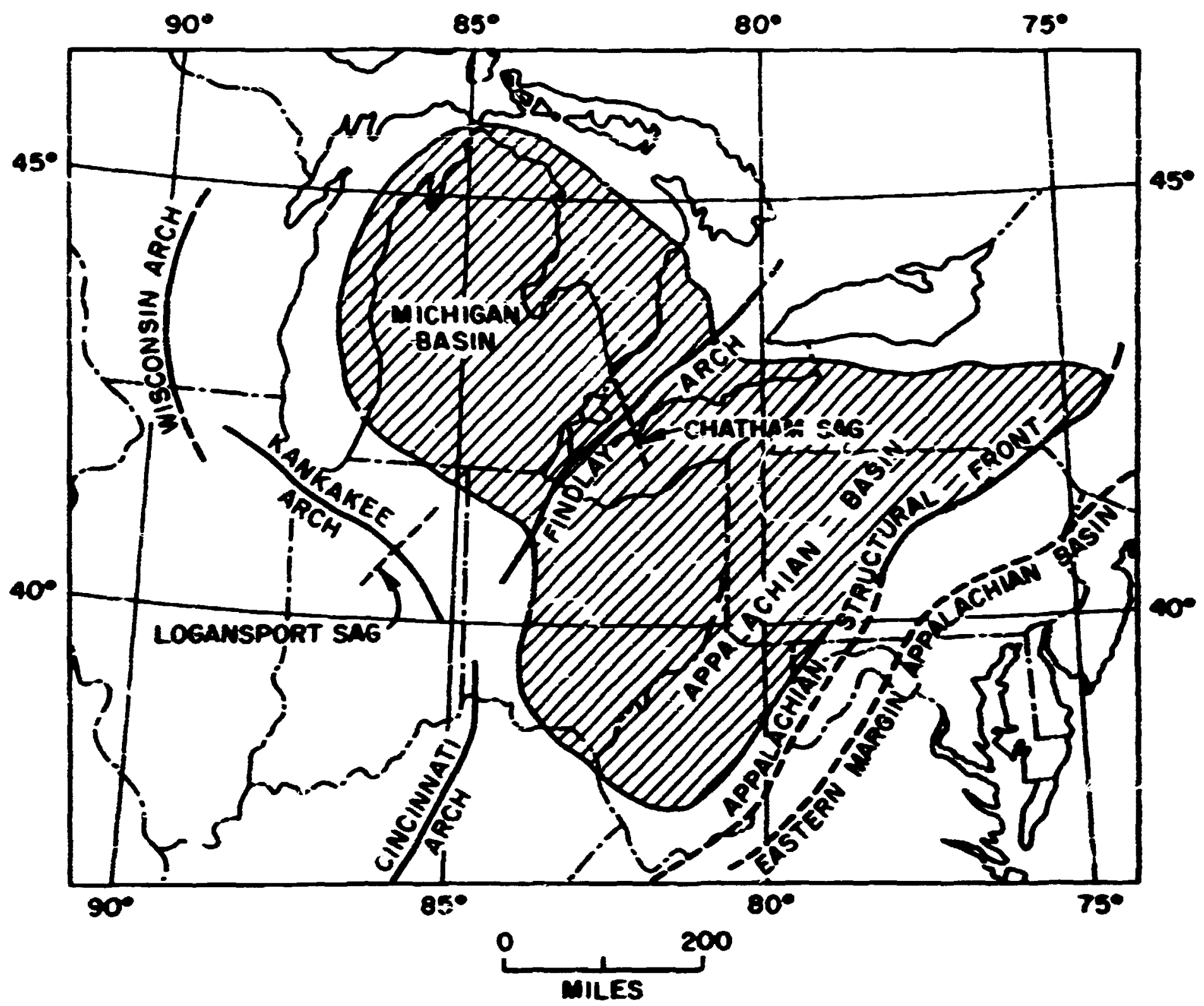

Fig. 2.21. Index Map, Shoring the Approximate Bxtent of the Salina Formation and Regional Structural Features Associated with the Salt. (After H. G. Pierce and E. I. Rich, U.S.G.S. Pulletin 1148, Pig. 3, p. $13,1.962$ ) 
total area underlain by salt is approximately $1.00,000$ square miles, and the average thickriess of the salt oeds is on the order of $150 \mathrm{ft}$.

The Salina formation ranges in thickness from 0 to nearly $1000 \mathrm{ft}$ anà consists of shale, dolomite, limestone, salt, anhydrite, and gypsum. The areas of greatest salt accumulation are in southern New York in the Appalachian basin and in the Michigan basin. The greatest aggregate thickress of salt occurs in the Michigan basin, where it ranges from $500 \mathrm{ft}$ at the margins to $1800 \mathrm{ft}$ in the center. The depth of the salt in the Michigan basin is from $500 \mathrm{ft}$ near the margin to $6000 \mathrm{ft}$ in the center. In New York, the maximum combined thickness of salt is about. $900 \mathrm{ft}$ southwest of Syracuse, with as many as six beds present in places. Here the salt is overlain by a shale formation 40 to $600 \mathrm{ft}$ thick. In Ohio, salt beds in the Salina are most numeruus in the northeastern pari of the state, where as many as eight have been recorded in wells. The aggregate thickness of the beds is from 0 to $300 \mathrm{ft}$; the thickest individual bed is about $50 \mathrm{ft}$. The greatest salt accumulations in Pennsylvania occur in the north-certral part of the state, where there are eik.ht beds with an aggrsgate tiaickness of about $650 \mathrm{ft}$. Indiviaual beds range from less than $5 \pm t$ to about $200 \mathrm{ft}$ in thickness, the thickest occurring near the top of the sequence. For the areas mentioned in New York, Pennsylvania, and Ohio, the top of the salt is about $1000 \mathrm{ft}$ below the surface. The Salina in West Virginia lies at depths greater than $5000 \mathrm{ft}$.

In addition to the Salina salt of Silurian age, there is a Devonian sal.t in the Iucas formation. It is present, only in the northern part of the southern peninsula of Michigan, and the areas of maximum aggregate thickness lie toward the deeper part of the Michigan basin at considerable depths. The Lucas consists of a series of salt units with anhydrite and shale interbeds; however, individual salt beds are measurable in tens of feet only.

Michigan Basin Hydrology (A. M. Piper ${ }^{*}$ ). - The occurrence of water both in surficial flacial deposits and the underlying bedrock units deserves coilsideration. 66 The glacial drift over most of the Michigan basin is several hunded feet thicis and is predominantly sandy. It has a high rate

*onsultant, Carmel, California. 
of recharge and stores water in relatively large volumes. In the most productive zones, buried sand and gravel outwash deposits, well yields range from several hundred to greater than $1000 \mathrm{gpm}$. Water from the upper drift contains about 200 to $500 \mathrm{ppm}$ of tota: dissolved solids and is moderately hard ( 175 to $350 \mathrm{ppm}$ as $\mathrm{CaCO}_{3}$ ). The chemical character changes with depth with iccreasing total dissolved solids (up to $1500 \mathrm{ppm}$ ) and hardness (up to $1000 \mathrm{ppm}$ ).

Although the glacial drift is separated from the underlying bejrock by a stratigraphic hiatus, the water contained in strata above and below react as a single hydrostratigraphic unit. These waters are referred to as transition-zone waters iue to the gradual change from fresh waters in the glacial drift above to brines in the bedrock beneath. The mix.ing is a proủct of three processes: (1) downward percolation of fresh meteoric water, (2) upward movement of nearly saturated deep brines due to natural nigration from higher to lower pressure head and artificie? drive induced by withdrarials from above, and (3) local dissolution of aquifer materials. Transitional waters are in st abundant in area.; where the drift is tinis and nonwater bearing, with numerous wells renetrating the upper bedrock.

Strata close below the Devonian salt and both above nnd below the Silurian salt are known or presumed to be water hearing. Highly concentrated netural brines have been found at depth in all strata that are nighly permeable over extensive areas. The Salina formation itself contairs very pure brines of natural origin in addition to the bedded salts.

In the Michigen area, the 800-it,-thick Lower Mississippian Coldwater shale is potentisily the major regional hydraulic barrier above the salt horizon. However, it contains potentizlly permeable beds of sandstone and limestone. The second most likely barrier, the Antrim shale of Upper Devonian age, contains "calcite balls" and appears to have developed some permeability by dissolution. On lithologic grounds, the two potential hydraulic barriers above the salt may be questionable.

Drilling operations have produced some artificisl rertical transmissibility that affects the integrity of the salt. Extraction of salt as 
artificial brine has accounted for a large fraction of the total production in Michigan and New York and nearly all the production in Ohio.

Srecific Localities. (K. K. Landes ${ }^{*}$ ). - Four geologic areas within the bcundaries of the Salira formation warrant further study, basec ' I the presince of relativeiy thick salt beds at accessible depths. These are no: theastern Ohio, western lrow York, and the southeast and northern portions of the southern peninsula of Nichigan.

The Salina formation in Michiger is divisible into seven members, designated A (oldest) through G. Three of the members are predominantly shale ( $C, E$, and $G$ ); three are predominantly salt ( $B, D$, and $F$ ); and one is salt in the basin center but dolomite at the margins (A). The B salt is absent at the out : margin of the basin but has a relatively uniform thicimess of 240 to $275 \mathrm{ft}$, over most of the basin. The D salt is the mosit persistent of the salts, also nearly pure, but the thinnest (25 to $55 \mathrm{ft}$ thick). The $\vec{r}$ unit ranges frum 0 io $i 200 \mathrm{t} t$, inin or absent at basin margins and thickest in the center; the percentage of salt in the unit increases outward and is highest near fire north edge of the basin. This $F$ salt has had the most mining activity. Both the $F$ and $P$ salts have been solution mined.

The Salina formation in southeastern Michigan underlies the dsnsely populated Detroit metropolitan area. Suitable salt units from the $B$ and A members of the Salina formation occur at depths ranging from 1120 to $2340 \mathrm{ft}$ below the surface. The thickness of individual salt sections range from 30 to $200 \mathrm{ft}$. At leas' one mechanical mine is operating in the area at present, removing sait from $1140 \mathrm{ft}$ below tise surface. The southeastern Michigar region as a whole has excel.lent transportation possibilities, including major Interstate highways and railroads.

Much of the region has been drilled for oil and gas exploiation and production. In addition, considerable solution inining of the salt, originally for production but more recently for storage of LPG, has taken place.

Consultant, Ann Arbor, Michigan. 
The most desirable Salina salt units in the northeastern portion of tife southern peitirsula lie along the Lake Huron shore in Alpena and Presque Isle counties. Several linestone units, the Traverse Group, and the Rogers City and Dundee limestones, 911 of Middle Devonian age, ilave been quarried sxtensively in the area. This activity has prompted the development of port facilities and rail connections. Drilling in the area has been minimal, but salt beds approximately $100 \mathrm{ft}$ thick are known to occur between 1600 and $2100 \mathrm{ft}$. Shallower salt beds protably exist in many areas, but trey are thinner.

In the Appalachian basin, the Silurian salts are generally deeper and have undergone greater deformation than those in the Michigan basin. 67 However, two areas, northerr. Or:io and central New York, contain relatively undisturbed salt at appropriate depths. The Ohio salt is in the vicinity of Cleveland and dips southeastward at approximately $30 \mathrm{ft} / \mathrm{mile}$. It has been mined by solution methods, generally at depths greater than $2000 \mathrm{ft}$, and by dry methods, at depths from 1700 to $2000 \mathrm{ft}$. In the existing drymines, faulting in the salt is evident and noticeable problems associated with instability of the salt, such as floor heaving, roof spalling, and pillar deterioration, have been experienced. The maximum aggregate thickness logged in the area is about $300 \mathrm{ft}$; however, individual beds are measurable only in tens of feet, rather than hundreds. In addition, the area has been quite heavily drilled for oil and gas prousction and exploration.

The most likely area for further study in New York is in the center c.f the western part of the state immediately west of the Finger Lakes in Livingston County and eastern lan:=ndiagua Lake County. West of this area the salt thins and is penetrated by numerous brine and gas wells. The salt is more unstable in the east ciue to past deformation. North of this area, the salt thius to extinction along a solution boundary; to the south, the salt is at considerable depth. In Livingston and Ceisandaigua Lake counties the salt occurs at depths of 1000 to $2000 \mathrm{ft}$ and has a southerly dip of about $60 \mathrm{ft} / \mathrm{mile}$. This county is the major salt producer in New York; and an existing mine, the Retsof, is the largest mine in the United States. The aggregate thickness of salt in this area may be suitable, but individual units are only tens of feet thicis. 
Williston Basin: Montana, North Dakoia, and South Dakota. - The Williston basin is a sedimentary and struciural basin covering an area of 150,000 square miles in the north-central United States and adjacent pcrtions of Saskatchewan and Manitoba. The basin contains 15,000 ft of sediments, Cambrian through Tertiary in age, including at least 11 salt units. The oldest of these units is Devonian; the youngest is Jurassic. 68

A very generei. look at the stratigraphy in the center of the basin shows the top 7000 it from the surface to Lower jurassic to be moitiy shales and sands. The next $2000 \mathrm{ft}$, from Lower Jurassic to Lower Mississippian, corsists of carborates, eraporites, and clastics. From 9000 to $15,000 \mathrm{ft}$ (Lower Mississippian to basement), the rucks are basically carbonates and a few significant evaporites. The majority of the salt in the United States portion of the basin occurs at depths ranging from 6000 to $9000 \mathrm{ft}$ below the surface. Figure 2.22 is an irdex map of the Williston basin.

The Devonian salt, Prairie formation, occurs at depths from 6000 to $12,000 \mathrm{ft}$ and varies from 0 ic $500 \mathrm{ft}$ in thickness. There are six distinct, Mississippian salts, primarily in the Charles formation; however, only one, the highest, is more than $100 \mathrm{f}$, tiick. One fairly extensive Permian salt bed in the opeche formation atteins 3 ihickness of $180 \mathrm{ft}$ and occurs at depths ranging from 5800 to $7500 \mathrm{ft}$. The highest salt units, the Pin? and Dunham saits, occur in Permian and Jurassic strata resfectively. The Pine has greater areal distributicn than most of the other salts and riaches a maximum thickness of $300 \mathrm{ft}$; the Dunham is more restricted and thinner than the Pine.

A large portion of the available water supply in the Williston basin region is saline. Paleozoic strata underlying the salt linits in the deeper portion of the basir contain highly saline brines. The only significant Mesozoic aquifers are Cretaceous, the principal one being the Dakota sandstone. This unit yields morerate to large supplies (150 to $>350 \mathrm{gpm}$ ) of highly mineralized water, with localized artesian conditions.

The Dakota aquifer is approximately $1300 \mathrm{ft}$ abuve the highest salt unit and separated from it by uhick shales. The primary source of fresh 


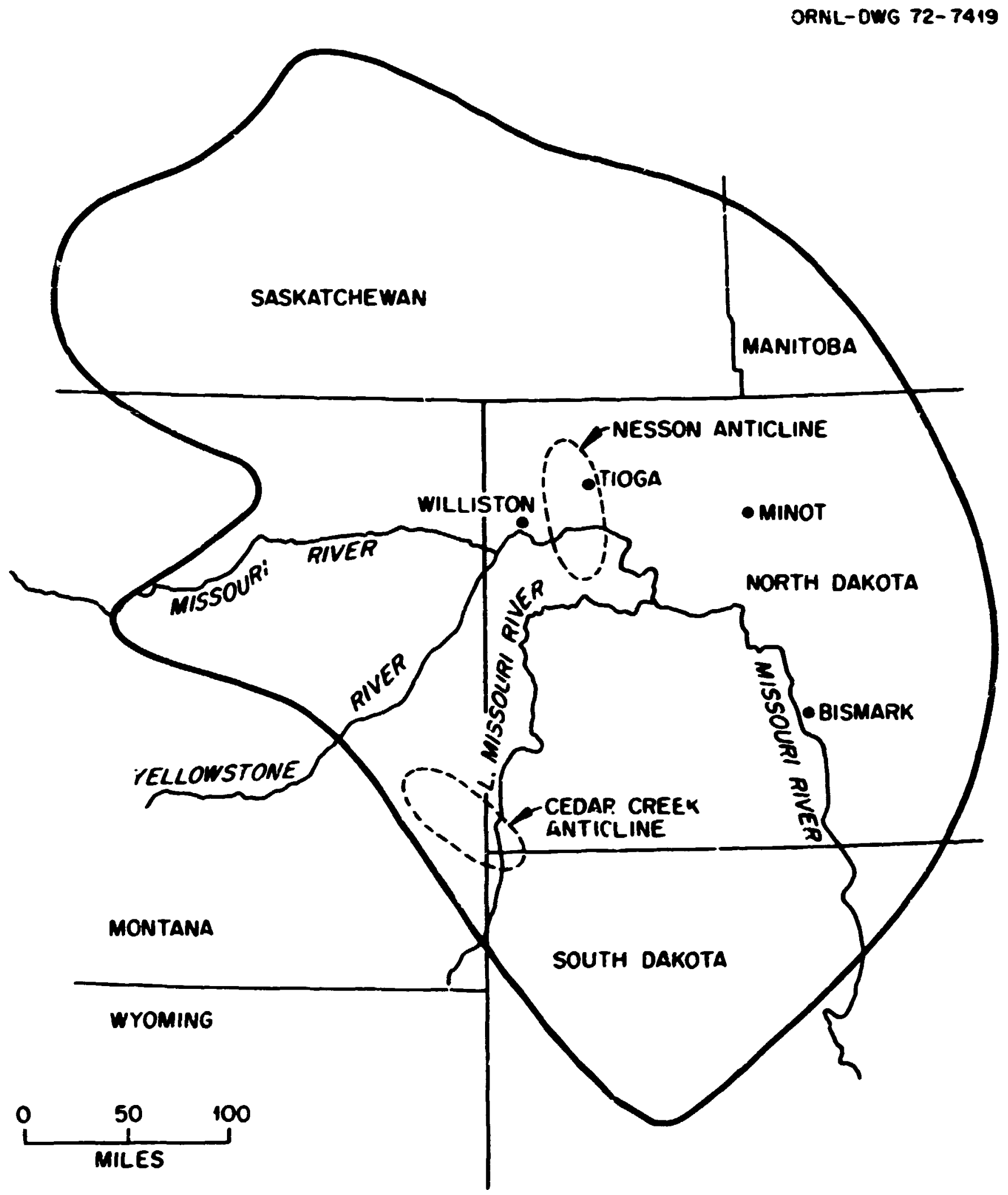

Fig. 2.22. Index Map of the Williston Basin. (After H. F. Reed, "Salt Deposits of the Williston Basin--United States Portion," Symposium on Salt, Northern Ohio Geological Society, Fig. 2, p. 150, 1961) 
ground water is the limited shailow aquifers associated with river channels, either of existing streams or of rormer glacial outwash channels.

The salt units of the basin have been s.bject to dissolution since Devonian time. Early cases from Paleozoic and Mesozuic time are thought to be local features, 1 or 2 miles in extent. Larger-scale dissolutioning, reiulting in the removal of large portions of the Devonian salt by subsurface waters, are known to be occurring at present in Saskatchewan and are inferred but not docuniented in the Urited States portion of the basin.

2.3.3 Argillaceous Formations (E. A. Merewether, ${ }^{*}$ J. A. Sharps,

Argillaceous formations, more specifically cleystones, mudstones, and shales, have been proposed as a promising alternative to salt deposits for disposal of radicactive waste. Argillaceous s:dinents are usually characterized by extremely low permeability and high ion exchange capaci.ty; and, in many cases, they are sufficiently plastic to prevent fracturing and the generation of secondary permeability. Plasticity generally decreases with compaction (and hence depth of burial); however, several factors contribute to the physical properties of shale (e.g. mineralogical composition, stratigraphic relationships, and geologic history of the sedimert), which makes it difiicult to generalize regarding sui.table environments in shales. 69

In general, shales of Paleozoic age are well compacted and compstent. In regions that nave undergone tectonic deformation such sheles tend to be crisscrossed by fractures. Mineralogically, Paleozoic shales are dominated by minerals of the illite and chlorite types with little or no montmorillonite present. Younger argillaceous sediments are more likely to have preserved some of their original plasticity and usually contain significant amounts of montmorillonite.

In review, the desirability of argillaceous formations as possible disposal sites can be evaluated, rased on the following factors:

*.S. Geological Survey. 
(1) Formation fimensions (lateral distribution, thickress, depth).

(¿) Mechanical properties (plasticity).

(3) Hydrolceic properties (porosity, primary and seconcary permeability, presence of water-bearing strata).

(4) Geclogic stability (faulting, seismicity).

(5) íineralogic properties (composition, ion exchan. capacity).

A review of the United States by physiographic regions has pinpointed several argillaceous formations which appear, on first appraisal, to meet many of the desirable qualities. In Michigan, the Devonian-Mississippian Ellsworth shale is most suictable at shallow depths on the north and northwest sides of the Michigan basin, where it directly underlies glacial deposits. In the southeastern Michigan basin, the Mississippian Joldwater shale may be suitable. In central and northern Chio the Devonian Ohio shale, Chargin formation, and Cleveland shale, and the Mississippian Bedford sl:ale comprise a thick sequence which has many of the necessary characteristics. The Devonian rorks in northwestern Pennsylvania, which include the Hamilton Group, Tully limestone, and Genesee, Sonyea, and West Falls Groups, have some potential for further exploration. In southeastern New York and northwestern New Jersey, outcropping shales of the Ordovician Trentor, Group may qualify. The Cretaceous Pierre stale and its lateral equivalents underlie much of the Rocky Mountains and Interior Plains regions. These shales range from 500 to $5000 \mathrm{ft}$ in thickness and usually have very high contents of muntmorillonite and mixed-layer illite-montmorillonite clay minerals.

\subsubsection{Specific Sites (D. W. Byerly ${ }^{*}$ )}

The three mines briefly described in this section were considered as pcsible locations for a radioactive waste repository in spite of the fact that the lithologies of the formaticns in which they are developed are considered to be unfavorable.

Gager Mine, Sherwood, Tennessee. - The Gager Mine is located on the Cumberland Plateau in central Tennessee. It is developed in the Mississippian Monteagle limestone, which is $180 \mathrm{ft}$ thick and quite variable in

\footnotetext{
* Consultant, Dept. of Geology, Univ. of Tennessee, Knoxville.
} 
ithology. The mine extends hcrizortally avout $1400 \mathrm{ft}$ from the access on the flank of a rearly fiat, sandstone-capped ridge.

The Gager Mine was developed in three levels. T'o upper two are generally drier than the lowest; however, cave-filling, dripstone formations, and solution channels observed in various parts of the mine attest to the fact that it is affectec. by percolating ground water.

Barberton Mine, Barberton, Ohic. - The Barberton Mine is located 40 miles south of Clevelard in the western Appalachian basin. The mine is developed in the Columbus limestone of Devonian age. The limestone is overlain by $1600 \mathrm{ft}$. of Devonian shales, with sandy shale (400 ft), sandstone ( $65 \mathrm{ft})$, and glacial drift (20 ft) completing the section. When the shafts were sunk, water was encountered only in the upper $300 \mathrm{ft}$ of drilling. The mine is ary with no evidence of percolating water. This can undoubtedly be attributed to the thick, impermeable shale above. The mine is located at a depth of appraximately $2300 \mathrm{ft}$; the mined volume is about $325 \times 10^{6} \mathrm{ft}^{3}$.

Demopclis Cavern, Marengo County, Alabsma. - The Demopolis Cavern, located in southwestern Alabama, is actually two IPG storage caverns which have been excavated in the Mooreville chalk. The Mooreville is a part of the Selma Group, Upper Cretaceous, which is essentially chalk containing some marl. The unit in which the storage caverns were develooed has a total thickness of $300 \mathrm{ft}$ and is a fai.ly uifiform chalky marl overlain by a hard medium-oedded chalk. Of the Selma Group, ine Mooreville is noted for its particularly low permeability. In places where it is exposed in a quarry face, a few solution channels ere visible near the surface.

The storage caverns are lorated at a depth of approximately $300 \mathrm{ft}$ and have a combined storage capacity of 15 million gallons.

\subsubsection{Conclusions}

Although the amount and detail of the information available for the severa]. study areas assambled in this prelimunary report were extremely variable, it is neverthelass possible to draw several tentative conclusions 
concerning the potential is the areas studied for siting a pilot plant waste repository.

The chief conclusions are that the southeastern New Mexico area of the Permian basin appears to be the most promising of the areas studied and that additional, more detailed, investigations of this fart of the basin are warranted. The principal factors leading to this conclusion are the large amount of geological data available because of the potash mining industry in tho region; the presence of extensive and thick beds or high-quality salt located at appropriate depths; the possibility of disposing of excess salt in the existing potash mine excavations; the ideal surface conditions of low rainfall and low population density; and the fact that most of the area is currently in federal ownership. The major aisadvantages appear to be related to an appreciable potential for future petroleum exploration and to certail hydrologic conditions.

Most of these hydrological problems involve local permeability of the formation overlying the salt unit and the resulting dissolution presently occurring at low rates in ports of the area. Althougn these problems must be investigated in detail, preliminary information suggests that they can be avoided by careful site selection.

All or the other areas studied seem to fall into two gensral categories: (1) those which appear to be promising for the future but inish would require either further extensive investigation or the satisfar:tory resolution of the problems associated with some potentially disqualifying characteristics, and (2) tinose which appear to be unsuitable for further consiaeration at, the present time.

The areas includer in the first category are as follows: (1) structures of the Paradox basin, (2) the Supai basin, (3) portions of the Salina basin, and (it) certain selected Gulf coast domes.

In the Paradox basin, the land surface characteristics such as population density, use, and ownership, etc., are again quite desirable and in many respects similar to those of the New Mexico area. Several salt structures in the form of large anticlines approach the surface to appropriate depths, and salt beds of suitable thickness and purity exist. 
However, due to the folding of the area and the thickening and plastic deformation which the salt in the structures has experienced, the strata and the salt beds are no longer flat and horizontal. This means that some difficulties in the undereround mining operations may be experienced and that it may be impossible to avoid the shales and the other nonchloride inits interbedded in the sait. Occasionally, the nonchloride units contain oil, gas, and brine. This may mean, as confirmed by the experience of the single potash mine which has operated in the area, that the repository would be required to operate under the rules and pr scedures for coal ard other "gassy" mines. Although the implications of such a requirement have not been analyzed in detail, satisfactory and practical operation of a waste repository would probably become exceedingly difficult.

The Supai basin in Arizona is also characterized by similarly desirable surface conditions of low population density and minimal utilization. Salt beds of appropriate depth, thickness, and purity appear to be present. ine limited amount of detailed data available seems to suggest that the thiciness of the salt beds is quite variable and that a sandstone aquifer at the top of the sait sequence may be responsible for some salt dissolution. These factors, taken together, imply that very extensive investigations would be required to confirm the suitability of any site in the Supai basin.

The most promising area of the Salina basin appears to lie in the zorthern part of the southern peninsula of Michigan. The salt beds in this area are isolated from circulating ground water by chick units of shale and anhydrite. However, in the areas where the depth to the salt is not excessive, the thickness of the suitable beds may not be adequate. Again, this implies that careful and extensive site selection and confirmation work would be required. The southeastern portion of Michigan is underlain by salt deposits having approximately the same geological characteristics as deposits in the northern part of the peninsula. However, these are considered mach less desirable because of the extremely high population density around metropolitan Detroit. It is also possible that satisfactory sites couid be found in other portions of the Salina basin, such as western New York State and northern Ohio. 
Several salt domer, that have been identified in the Gulf Coast region can be cunsidersi foientially slitaile on the basis of present information. In these lcmes, the salt is located at appropriate depths and has not been developed for any other purpose. The purity of the salt in Gulf coast diapiric structures is usually excellent, and the thickne;s of the salt in a vertical direction varies from 10,000 to $15,000 \mathrm{ft}$ in the isterior basins to greater than $30,000 \mathrm{ft}$, in the coastal basins. Potential protlens with Gulf loast domes include juestions about tectonic stability and rates of dissolution - both of which would require extensive investigation in order to confirm the suitability of any particular dome. In addition, the limited horizontal extent of domes, in relation to the requirement for a buffer zone surrounding the repository area, presents certain problems that might best be resoived by either a modification of the current waste disposal concept or the develcpment of a new and diffcrent concept which would take better advantage of the shape of the salt mass.

The final grouping of areas includes: (I) the Williston basin, (2) the Iuke salt body, (3) argillaceous formations in general, and (4) the three specific sites in calcareous rociss which were examined. For the reasons summarized below, it is felt that these areas offer limited potential and do not merit additional consideration at this time.

All of the salt deposits of the Williston basin are located at depths exceeding $4000 \mathrm{ft}$ and, therefore, are too deep to be practical, at least with the present, waste emplacement concepts.

The Luke salt body offers salt of high purity and satisfactory thickness in the appropriate depth range. However, the limited extension of the deposit and its proximity to the Luke Air Force Base and to the Phoenix metropolitan area are serious drawbacks.

The cursory review of argillacecus formations has not indicated any particularly promising environuent or specific area. However, it should be emphasized that, with the scale of the present study, potential promising areas might have been overlooked. It should also be emphasized that a repository in these materials would probably require the 
development of modified burial concepts and would certainly call for extensive investigation of the physical properties of these rock types at elevated temperatures.

Of the three specific sites in calcareous formations, the two shallow ones can be inmediately rejected on the basis of insufficient isolation. The remaining one, the Barberton Mine in Ohio, is located in a dry 2:imestone formation underlying $1600 \mathrm{ft}$ of impermeable shale. Extensive studies would be necessary to evaluate the reliability of the shale as a barrier to ensure long-term containment of the wastes. However, at the present time, it is felt that the plasticity of the shale formation might not be adequate to maintain the integrity of the shale in case of tectonic movements. 


\subsection{Natural Containment Studies}

The physical and mechanical properties of the geological fomations of a disposal site influence the ability of the formations tc adequately isolate the wastes. The thermal conjuctivities of the various for ations involved become critical when thermal gradients develop as the result of heat transfer from the waste packages to the surrounding geologic medium. The development and operation of heat flow equipment for the messurement of thermal properties are discussed in sect. 2.4.1.

Stale rocks are nearly always assuciated with bedded salt deposits. When these shales are subjected to the expested elevated temperatures, there is a possibility that certain clay minerals will experience partial dehydration, wich, in turn, could lead tw abnormally high pore pressures. Investigations of the pctentig? for this process are describud in Sect. 2.4 .2 .

The rock mechanics analysis dischssed in ject. 2.4.3 are directed toward evaluation of the mechanical efiects that the operations of the repository will have on the surrounding rock strata and their potential for leading to conditions in which the reologic containment of the wastes could be breached.

\subsection{Thermal Conductivity of Rocks (T. G. Godfrey, D. L. HeElroy, S. H. Jury*)}

The natural structural materials of a salt mine area vary from stone or shale-like substances to ordinary salt deposits. If such an area is to be used as a repository for nuclear waste, the thermal properties of these substances must be known. Thus we have developed and operater heat flow equipment for measuring thermal properties. Tis work yielded a new measurement technique, termed the "transient piane probe," plus other developments, all of which are described in Sect. 3.2.3.

Introductory Description of the Transient-State Plane Probe Heat Flow Equipment. - A survey of methods and apparatus for lueasuring the thermal conductivities and the thermal diffusivities of core samples was

\footnotetext{
* Consultant from the University of Tennessee, Knoxville.
} 
required prior to making actua?. measurement: of samples from a repository area. The following factors incicated the need for an apparatus with broad applicability: (1) the nature and number of core samples invosved, (2) their anisotropic characteristics, (3) a minimum amount of machining of test specimens, (4) a precision of $1 \%$ consistent witk relatively rajid measurement, (5) thermal properties ranging from inorganic powders to poorly conducting metals, and (6) use of specimens down to 3 in. in size.

The results of this survey showed that the plane probe, iliustrated in Fig. 2.23, was best suited to the purpose. Its transient-state mathematical analysis and applicatica to experimental results are relatively straightforward, making it more attractive than some others which use an approximate ansiysis.

The proie material is divided into tro parts, with a thermocouple sanasiched in between. The thermal diffusivity, $\alpha_{2}$, and the thermal conductivity, $\lambda_{2}$, of the probe material are known. The plane probe heater is etcied spirally in the copper lamination of a printed circuit board of Fortin Micro-Clad Kapton. ${ }^{*}$ The copper cladding cen be cbtained in thickresses from 350 to $2800 \mu$ in. (0.35 to 2.8 mils) on Kapton plastic in thicknesses from 0.5 to 3 mils. One $f f e$ of the tost specimen is ground flat, and a hole is drilled for inserting a thermocosple at a depth $x_{1}$, as shown in Fig. 2.23.

The general principle of operation involves ciamping the sandwich togetiner and letting its temperature stabilize at a selectec valie. The PDP-8 computer is programed to turn on the power supply and then measure the two thermocouple enfs and heater power at 15-8ec intervals over a period of 130 to $150 \mathrm{sec}$. The computer processes these data and yields values of $\alpha_{1}$ and $\lambda_{1}$ for the sample. By repeating the test at other temperatures, $\alpha_{1}$ and $\lambda_{1}$ can be determined as functions of temperature.

Mathematical Analysis of the Playe Probe. - The plane probe mathematical representation for the transient data analysis is described below. The Kapton and copper cladding can be chosen so trin that one can assume

\footnotetext{
Kapton is a trademark of the duPont de Nemours and Comany, Wilmington, Del., for a folyimide film. Hicro-Clad is a trademark of the Fortin Laminating Corporation, Sar. Fernando, Calif.
} 


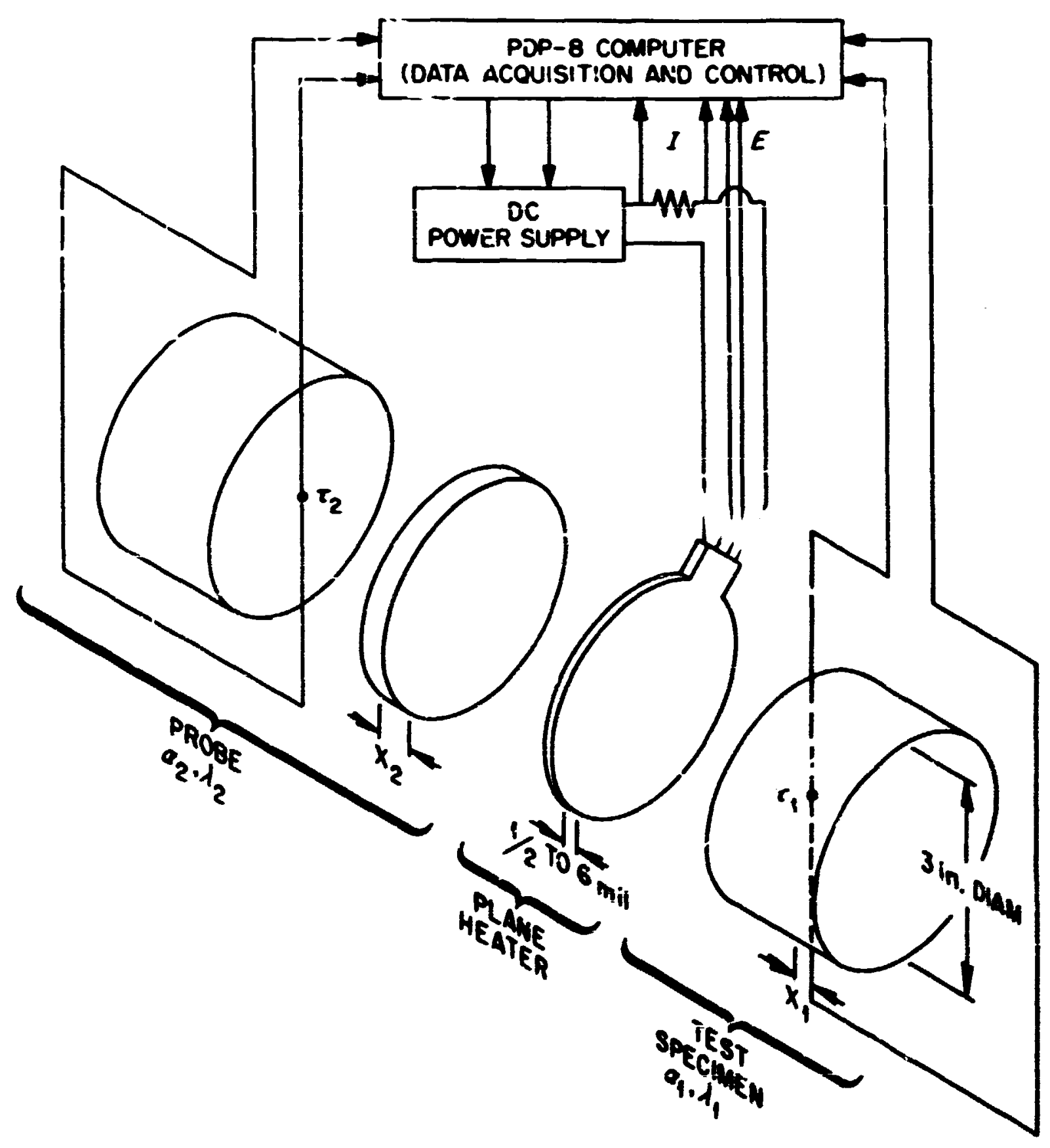

Fig. 2.23. General Description of the Transient-State Plane Probe. The prove and heater are permanently bonded together and are pressed against the test specimen. 
the heater is a plane which stores little or no heat. The 3-in. diameter is large enough, in comparison wi th the thickness of the sandwich shown in Fig. 2.23, that radial effects in the governing partial differential equation can be neglected; thus,

$$
\frac{\partial T}{\partial t}=\alpha \frac{\partial^{2} T}{\partial x^{2}}
$$

where $T=T-T_{0} ; T_{0}=$ starting reference temperature. At the heater,

$$
F_{0}=F_{1}+F_{2}
$$

where

$F_{0}=$ total flux developea at the heater, $B t u / h r \cdot f t^{2}$ of the plane probe, $F_{1}=\lambda_{1} \partial \tau_{1} /\left.\partial x\right|_{x=0}$,

$F_{2}=\lambda_{2} \partial \tau_{2} /\left.\lambda x\right|_{x=0}$.

The solutions to the test specimen and probe parts are:

$$
\begin{aligned}
& \tau_{1}-\tau_{0}=\frac{2 F_{0} \sqrt{t}}{\frac{\lambda_{1}}{\sqrt{\alpha_{1}}}+\frac{\lambda_{2}}{\sqrt{\alpha_{2}}}} \dot{i e r f c}-\frac{x_{1}}{2 \sqrt{\alpha_{1} t}} \\
& \tau_{2}-\tau_{0}=\frac{2 F_{0} \sqrt{\tau}}{\frac{\lambda_{1}}{\sqrt{\alpha_{1}}}+\frac{\lambda_{2}}{\sqrt{\alpha_{2}}}} \operatorname{ierfc} \frac{\left|x_{2}\right|}{2 \sqrt{\alpha_{2} t}}
\end{aligned}
$$

where

$$
\begin{aligned}
\text { ierfc } x & =\frac{e^{-x^{2}}}{\sqrt{\pi}}-x[1-\operatorname{erf} x] \\
\tau_{1}, \tau_{2} & =\text { temperatures read at respective thermocouples. }
\end{aligned}
$$

The ratio of the two solutions shows that, at any instant,

$$
\left(\frac{\tau_{1}-\tau_{0}}{\tau_{2}-\tau_{0}}\right) \operatorname{ierfc} \frac{\left|x_{2}\right|}{2 \sqrt{\alpha_{2} t}}=\operatorname{ierfc} \frac{x_{1}}{2 \sqrt{\alpha_{1} t}}
$$

We car calculate a queisity $Y$, defined as:

$$
r=\frac{x_{1}}{2 \sqrt{\alpha_{1} t}} \text {. }
$$


A plot of $Y$ vs $1 / y^{\prime}$ has a slope $x_{1} / 2 \sqrt{\alpha_{1}}$, from which we can calculate $\alpha_{1}$. From the orifrinai solution for $\tau_{1}$, we can plot $\tau_{1}-\tau_{0}$ vs $\sqrt{t}$ ierfe $\frac{x_{1}}{2 i \frac{1}{1}} \bar{t}$, and the slope is:

$$
\frac{2 F_{0}}{\frac{\lambda_{1}}{\sqrt{\alpha_{1}}}+\frac{\lambda_{2}}{\sqrt{\alpha_{2}}}} \text {, }
$$

from which we can calculate $\lambda_{1}$.

Currently the various parts of the probe are being fabricated and the computer program for the PDP- 8 is being written. Other methemptical investigations of the probe have been made in order to better understand edge effects.

\subsubsection{Mineralogic'sl Studies}

Water is undorbtedly the critical potential dispersing medium of radioactive nuclides introduced at depth in the earth's crurst. Essential requirements of the disposal formation are the absence of circulating ground water and extremely low formation permeabilities. However, some water is always present in geologic materiais; even rock salt, which is one of the driest geclogic environments, has a brine content ranging from less than $1 \%$ to a few percent. In addition to free water contained in pores and fractures, bater can exist in geologic materials in the form of acisorbed water and as water of crystallization.

Adsorbed water is abundant in clays, especially in the clay minerais of the smectite group. * water of crystallization is present in several hydroüs evaporite finerais (e.g., gopsum, polynalite, and carnallite).

Because both adsorbed and crystallization water can be released upon heating, the mineralogical composition of the rocks in which the radioactive wastes might be placed is of interest. As a consequence of decay heat generated in tise wiste, geological materials overlying and underlying the disposal beds will be heated to relatively high temperatures to 2 distance of several hundred feet. Therefore, the mineralogy and possible

* Smectite is a group rame for all clay minerals with an expanding lattice, except vermiculite; montmorillonite is the name of a specific mineral in the smectite group. 
dewatering mechanisms must be investigated in all the zones that might be heated to significant temperatiues. Ir addition, the possioility that. dewatering might lead to the generation of abnormally high pore pressures, with the relaced potential instability, should be investigated.

These considerations led to three studies:

(1) An examination of the mineralogy of shales overlying the Hutchinsor sait.

(2) A study of the mineralogy of the Hutchinson salt member.

(3) Investigation of the occurrerce and genesis of abnormal pore fluid pressures.

While the third study is general in nature and consists of a literature review aimed at an understanding of the probiem, the first two studies are partially site specific. At the time these studies were initiated, the only available sorples were those from the Lyons, Kansas, cores; thus it was decided to use them but to limit the number of analyses and concentrate on the development of techniques and equipment.

The zesults obtained $t$, date in these studies are summarized below. Mineralogy of Shales (Gale K. Billings* ${ }^{*}$ ). - The tests performed on the shale samples incilude:

(1) Determination of sodium by neutron activation analysis.

(2) Determination of chloride for water-solible salts.

(3) Total carbonate for carbonate minerals.

(4) Bulk sanple $x$-ray diffraction.

(5) I.ess than $2 \mu$ (clay fraction) $x$-ray diffraction.

(6) Less than $2 \mu$ glycolated $x$-ray diffracticn.

(7) Less than 2 , heated $\left(625^{\circ} \mathrm{C}\right) \mathrm{x}$-ray diffraction.

(8) Letermiration of unbound wätar.

(9) Determination of structural water.

On the basis of these analyses, the quantitative chemical and qualitative mineralogical compositions of the rock samples have been defined The

* New Nexico Institute of Mining and I'echnology. 
results of the chemical analyses are shown in Table 2.7; the description and depth of the samples are given in Table 2.8 .

The mineralogical analyses are quaitative in nature; however, they indicate the common presence of mcntmorillonite, mixec-layer clays, and chamosite. These minerals seem to be more abundant in the samples from the lower half of the cort.

The data on quantitative mineralogical composition of the rock samples will be obtained by the use of an especially perfected computer technique. The method is based on two approaches: (1) assuming quasiequilibrium, one can allocate the chemical elements in a rock sample to the minerals believed to be present on the basis of minimizing entropy of the system, using published thermodynamic data; (2) one can also approach mineralogical : nalysis by using the chemical data and a series of rezression analyses to allocate the chemicals to theoreticai, pure end-member mineralogy. Both a mojor element chemical analysis and a semiquantitative or qualitative mineralogical analysis are required.

In addition, an effort has been directed to the development of a water analysis technique capable of determining the amounts of interstitial, loosely bound, and structural water in clays.

Mineralogy of Evaporites (Otto C. Kopp ${ }^{*}$ ). - An extensive search of the literature for articles related to evaporite mineralogy has served as background for this study and as the basis of a reasonably complete bibliography of the subject which is being generated.

The experimental work with samples involved (1) $x$-ray analyses for the determination of bulk mineral assemblages, (z) mineralogical determinations frcm petrographic thin sections, and (3) thermal analyses to define the dewatering of specific minerals and bulk rock samples. The samples studied were those from the core from AEC Hole No. 1 in Lyons, which had been judged to be rich in evaporite minerals, along with the samples obiained from the Carey mine in Lyons.

*University of Tennessee. 
144

Tuble 2.7. Chemical Analyses (in wt \$)

\begin{tabular}{|c|c|c|c|c|c|c|c|c|}
\hline Saple 10. & $\mathrm{SiO}_{2}$ & $\mathrm{Al}_{2} \mathrm{O}_{3}$ & $\mathrm{CuO}$ & 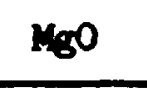 & $\mathrm{Fe}_{2} \mathrm{O}_{3}^{\mathrm{a}}$ & $\mathrm{K}_{2} \mathrm{O}$ & $\mathrm{He}_{2} \mathrm{O}$ & $\mathrm{TiO}_{2}$ \\
\hline 1 & 43.35 & 18.45 & 3.35 & 5.19 & 12.25 & 7.47 & 1.49 & 0.59 \\
\hline 2 & 6.81 & 3.60 & 21.70 & 8.57 & 0.72 & 1.04 & 0.30 & 0.00 \\
\hline 3 & 48.89 & 16.42 & 13.18 & 4.63 & 12.12 & 5.82 & 1.71 & 0.81 \\
\hline 4 & 41.80 & 17.85 & 1.55 & 3.62 & 3.4 .23 & 7.11 & 1.46 & 0.64 \\
\hline 5 & 46.65 & 20.40 & 1.44 & 3.23 & $: 14.76$ & 7.88 & 1.37 & 0.69 \\
\hline 6 & 51.75 & 16.60 & 2.45 & 4.99 & 10.13 & 5.48 & 3.72 & 0.80 \\
\hline 7 & 54.90 & 15.65 & $0.9 \overline{9}$ & 6.55 & 8.65 & 4.99 & 1.47 & 0.69 \\
\hline 9 & 54.72 & 15.47 & 1.69 & 4.35 & 3.10 & 4.79 & 1.81 & 0.79 \\
\hline 9 & 47.01 & 17.13 & 2.11 & 7.63 & 11.33 & 5.96 & 1.83 & 0.72 \\
\hline 10 & 57.50 & 15.52 & 1.83 & 5.24 & 8.07 & 4.99 & 2.26 & 0.68 \\
\hline 21 & 45.56 & 16.84 & 2.51 & 6.66 & 13.18 & 6.71 & 1.68 & 0.60 \\
\hline 12 & 47.37 & $17 \cdot 32$ & $3 \cdot 38$ & 5.39 & 12.94 & 6.75 & 1.68 & 0.67 \\
\hline 13 & 49. 34 & 17.13 & 1.44 & 5.22 & 18.54 & 7.18 & 1.72 & 0.75 \\
\hline 14 & 52.97 & 13.87 & 4.02 & 6.95 & 5.54 & 4.69 & 1.74 & 0.67 \\
\hline 15 & 38.51 & 11.31 & 8.06 & 9.47 & 7.70 & 5.54 & 1.64 & 0.45 \\
\hline 16 & 20.06 & 3.72 & 16.19 & 13.06 & 5.75 & 4.00 & 1.45 & 0.15 \\
\hline 17 & 47.76 & 15.83 & 1.06 & 4.44 & 9.97 & 5.66 & 2.66 & 0.77 \\
\hline 19 & 49.73 & 12.74 & 1.36 & 6.62 & 11.69 & 4.35 & 2.55 & 0.80 \\
\hline 20 & 37.66 & 11.21 & 7.71 & 10.00 & 8.26 & 5.10 & 1.77 & 0.41 \\
\hline 21 & 29.99 & 7.00 & 4.59 & 14.62 & 9.08 & 4.27 & 2.17 & 0.42 \\
\hline 23 & 46.39 & 13.58 & 0.99 & $7 \cdot 36$ & $12 \cdot 37$ & 4.68 & 8.16 & 0.58 \\
\hline 24 & 41.20 & 12.87 & 2.07 & 4.80 & 9.95 & 4.64 & 8.35 & 0.46 \\
\hline 25 & 38.03 & 12.96 & 3.90 & 8.34 & 8.78 & 5.12 & 2.28 & 0.53 \\
\hline 26 & 37.18 & 14.30 & 1.43 & 7.17 & 10.80 & 5.08 & 4.38 & 0.58 \\
\hline 27 & 35.93 & 12.26 & 5.35 & 8.36 & 7.91 & 4.98 & 2.73 & 0.47 \\
\hline 28 & 45.93 & 12.73 & 1.01 & 6.74 & 12.7 & 4.04 & 3.00 & 0.74 \\
\hline 30 & 42.14 & 10.90 & 9.67 & 7.51 & 6.59 & 5.45 & 1.61 & 0.39 \\
\hline
\end{tabular}

Total Pe as $\mathrm{Fe}_{2} \mathrm{O}_{3}$. 
Table 2.8. Desci-iption and Depth of Analyzed Samples frox Corshole AFC No. 1, Lyons, Kansas

\begin{tabular}{|c|c|c|}
\hline $\begin{array}{l}\text { Sample } \\
\text { No. }\end{array}$ & $\begin{array}{l}\text { Depth } \\
(\mathrm{ft})\end{array}$ & Description \\
\hline 1 & 324.9 & $\begin{array}{l}5 \text { in. intercolated red and green clays with very } \\
\text { minor silt; sample from red horizon }{ }^{2}\end{array}$ \\
\hline 2 & 309.5 & $\begin{array}{l}2 \text { in gypsum; } 1 \text { in. firely laminated white-gray } \\
\text { clay shale; } 1 / 2 \text { in. above shale w: th stringers of } \\
\text { gypsum; } 3 \text { in. white to gray clay siale (nonfissile } ;^{2} \\
3 / 8 \text { in. interbedded gypsum and shale }\end{array}$ \\
\hline 3 & 352.7 & $\begin{array}{l}3-1 / 2 \text { in. red siltstone massive; }{ }^{a} 1-1 / 2 \text { in. laminated } \\
\text { siltstone }\end{array}$ \\
\hline 4 & 382 & $\begin{array}{l}5 \text { in. fine red claystone (minor silt) intercolatea } \\
\text { with miror blue-gray clay }\end{array}$ \\
\hline 5 & $393 \cdot 5$ & 3 in. red clay with minor silt \\
\hline 6 & 415 & $\begin{array}{l}14 \text { in. gopsum; } 3 \text { in. intercolated clay and gypsum; } \\
5 \text { in. red clay (mi:or silt); } 2 \text { in. intercolated } \\
\text { gypsum and clay }\end{array}$ \\
\hline 7 & 435 & $\begin{array}{l}1 \text { in. red ziltstone with secondary gypsum in } \\
\text { fractures and bedding planes }(\sim 5 \%) ; 1-1 / 2 \text { in. blue- } \\
\text { green clay; minor gypsum }\end{array}$ \\
\hline 8 & 456 & $\begin{array}{l}3-1 / 2 \text { in. red fine-grained siltstone; minor sprin- } \\
\text { kling of crystals (gypsum?) throughout sample }\end{array}$ \\
\hline 9 & 475 & $\begin{array}{l}3 \text { in. red and blue-gray siltistones with a few small } \\
\text { pods of gypsum along bedding planes }\end{array}$ \\
\hline 10 & 495 & $\begin{array}{l}3 \text { in. redaish clay-shale; fractures filled with } \\
\text { gypsum; also zones that appear to be secondary } \\
\text { replacement (pods) }\end{array}$ \\
\hline 11 & 520 & $2-1 / 2$ in. variegated red and green clay-shale \\
\hline 12 & 540 & $\begin{array}{l}2 \text { in. red clay; }{ }^{2} 1 \text { in. bluish clay and red clay } \\
\text { more than } 50 \% \text { replaced by evaporite minerals }\end{array}$ \\
\hline 13 & 556 & $\begin{array}{l}4 \text { in. variegated shale-desp red to gray-white } \\
\text { minor silt; deep red is much finer; }{ }^{\circ} \text { may be } \\
\text { evaporites in whitish stringers. }\end{array}$ \\
\hline 14 & 575.5 & $\begin{array}{l}3-1 / 2 \text { in. gray shale with minor evaporite mineral } \\
\text { crystals; darkest portion }{ }^{\mathrm{a}}\end{array}$ \\
\hline 15 & 597.0 & $\begin{array}{l}1 / 2 \text { in. gray shale and evaporites; } 1 \text { in. gray shale; } \\
2 \text { in. fracture filling - gypsum; } 1 \text { in. siale and gypsur }\end{array}$ \\
\hline
\end{tabular}


Table 2.8 (contd)

\begin{tabular}{|c|c|c|}
\hline $\begin{array}{l}\text { Sample } \\
\text { No. }\end{array}$ & $\begin{array}{l}\text { Depth } \\
(\mathrm{ft})\end{array}$ & Description \\
\hline 16 & 522 & $\begin{array}{l}1 / 4 \text { in. evaporites; } 3 \text { in. gray-black shale, very } \\
\text { hard (organic matter?); } 2 / 3 \text { in. evaporites }\end{array}$ \\
\hline 17 & 634 & $\begin{array}{l}\text { I in. black shale; } 2-1 / 2 \text { in. gypsim and shaie in } \\
\text { stringers; } 3-3 / 4 \text { in. gray-black shale; }{ }^{2} 1 \text { in. } \\
\text { gopsum }\end{array}$ \\
\hline 18 & 655 & 3 in. massive $g_{j}$ psum stringers in green shale \\
\hline 19 & 674 & $\begin{array}{l}4 \text { in. red siltstone with minor pods and stringers } \\
\text { of evaporites }\end{array}$ \\
\hline 20 & 726.6 & $\begin{array}{l}4 \text { in. variegated black-gray shale; black layers } \\
\text { fissile and brittle }\end{array}$ \\
\hline 21 & 755.5 & $\begin{array}{l}3 \text { in. black shale with evaporite stringers; } \\
1 \text { in. grpsum and black shale }\end{array}$ \\
\hline 22 & $767 \cdot 5$ & $\begin{array}{l}2 \text { in. gypsum }(60 \%) \text { and gray shale }(40 \%) \text {; not } \\
\text { s:ampled }\end{array}$ \\
\hline 23 & 805.5 & $\begin{array}{l}\text { Gray shale, shattered and containing } 3 \text { in. stringers } \\
\text { of evaporites (salt) }\end{array}$ \\
\hline 24 & 870 & $\begin{array}{l}2-3 / 4 \text { in. red shale; gypsum filling fractures; } \\
\text { ninor blue-gray stringers }\end{array}$ \\
\hline 25 & 904 & $\begin{array}{l}\text { Salt encrusted on outside; } 6 \text { in. disturbed black } \\
\text { mass (soft) some evaporite replacement; took } \\
\text { horizontal split of darkest color section }{ }^{a}\end{array}$ \\
\hline 26 & 1061 & $\begin{array}{l}3-1,2 \text { in. gray-black shale with reddish salt } \\
\text { fractures; minor gypsim }\end{array}$ \\
\hline 27 & 1094 & 5 in.; $70 \%$ shale; $30 \%$ evaporites \\
\hline 28 & 1118.4 & $\begin{array}{l}4 \text { in. reddish clay with evaporite stringers and } \\
\text { secondary crystals; sampled middle section }{ }^{2}\end{array}$ \\
\hline 29 & 1181 & 4 in. evaporites with minor shale \\
\hline 30 & 1293 & 5 in. green elay \\
\hline
\end{tabular}

${ }^{a_{\text {Refers }}}$ to analyzed fraction when sample was not homogeneous. 
Results of the $x$-ray analyses of samples from AEC Hole No. I indicate that gypsum disappears as a major phase at a depth somewhere between 600 and $800 \mathrm{ft}$. During the course of the $x$-ray analyses it was ascertained that determination of the amounts of gypsum and anhydrite present in the sample is possible at the 2 wt $/$ leveI (and below;. The procodure involves preparation of standard mixtures from halite, gypsum, anhydrite, shale, and quartz. The resulting powders are pressed in aluminum caps for 5 min at 4000 psi, resulting in disks for which the random effects of hand packing in ordinary holders are minimized. The data are defined by least-squares analyses to determine the best straight-line fits, and plots preparea in which the intensities of the diffracted $x$-rays are related to the percentage of gypsum and anhydrite in the mixture.

Static heating tests of gypsum and whole rock samples have been conducted for weight loss determinations. Tests were run on six size fractions of gypsum at $102 \pm 3^{\circ} \mathrm{C}, 75 \pm 3^{\circ} \mathrm{C}$, and $60 \pm 3^{\circ} \mathrm{C}$. No weight losses were detected in the samples after a period of 2 weeks at $60 \pm 3^{\circ} \mathrm{C}$. Figures 2.24 and 2.25 show the dehydration curves for gypsum at $102 \pm 3^{\circ} \mathrm{C}$ and $75 \pm 3^{\circ} \mathrm{C}$ respectively. Dehydration proceeds at a much higher rate at $10 \% \pm 3^{\circ} \mathrm{C}$, as was expected. The rate of dehydration is inversely proportional to the particle size, with the exception of the 50 - to 100mesh fraction. No explanation of the anomalous behavior of this fraction can be offered at this time; however, it seems probable that it is related to the experimental procedure. The weight losses observed at $75 \pm 3^{\circ} \mathrm{C}$ correspond to the development of the hemihydrate phase $\left(\mathrm{CaSO}_{4} \cdot 1 / 2 \mathrm{H}_{2} \mathrm{O}\right)$, although this has not yet been confirmed by $x$-ray analysis.

Thus far, the primary emphasis in the static heating tests has been on gypsum, but the more critical question to be addressed is the total amount of water that could be released from a whole rock sample upon heating. The weight losses of rock samples from AEC Hole No. 1 have been studied. Some of the results (i.e., results from the first group of six samples) are as follows: 


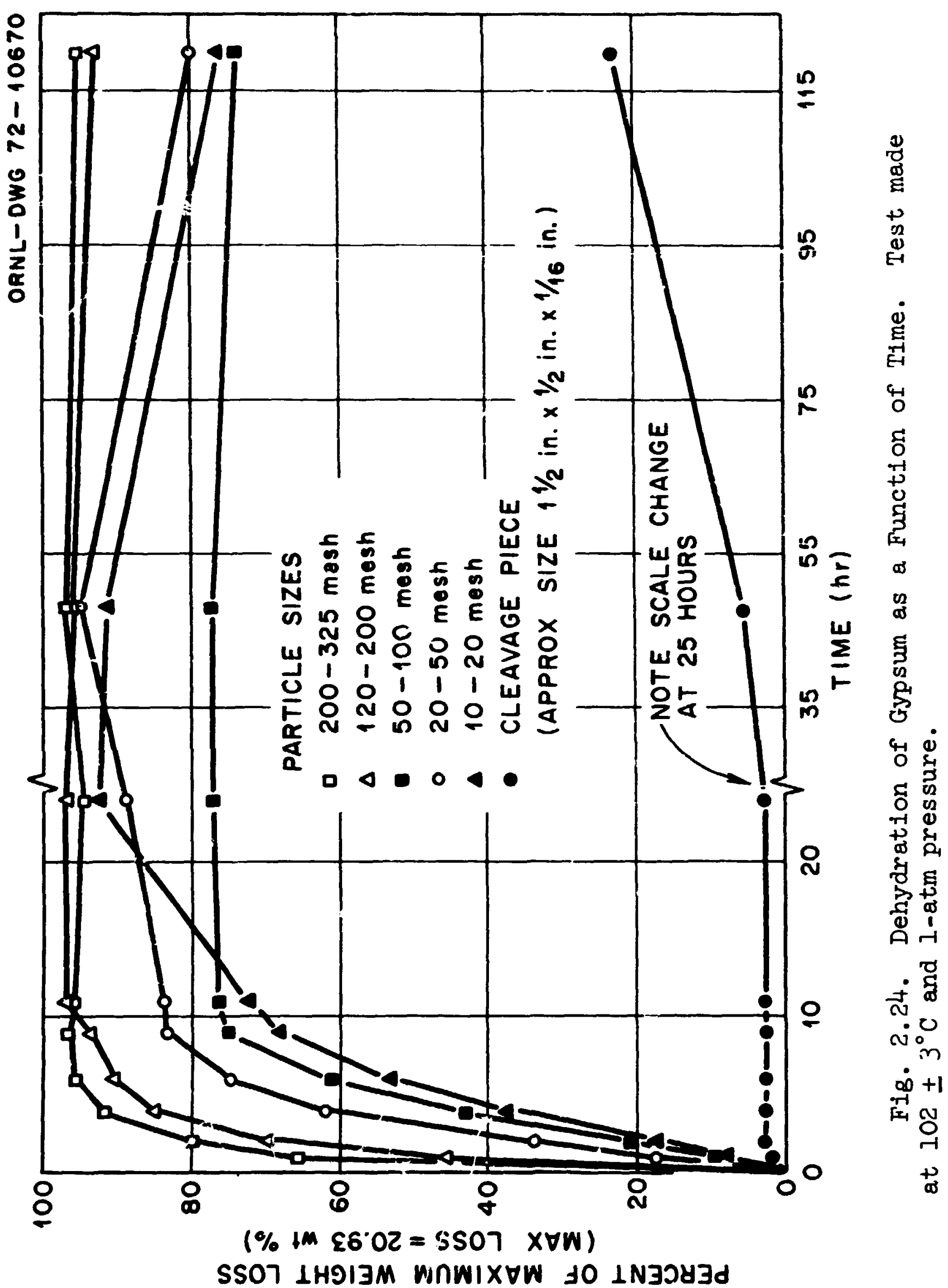




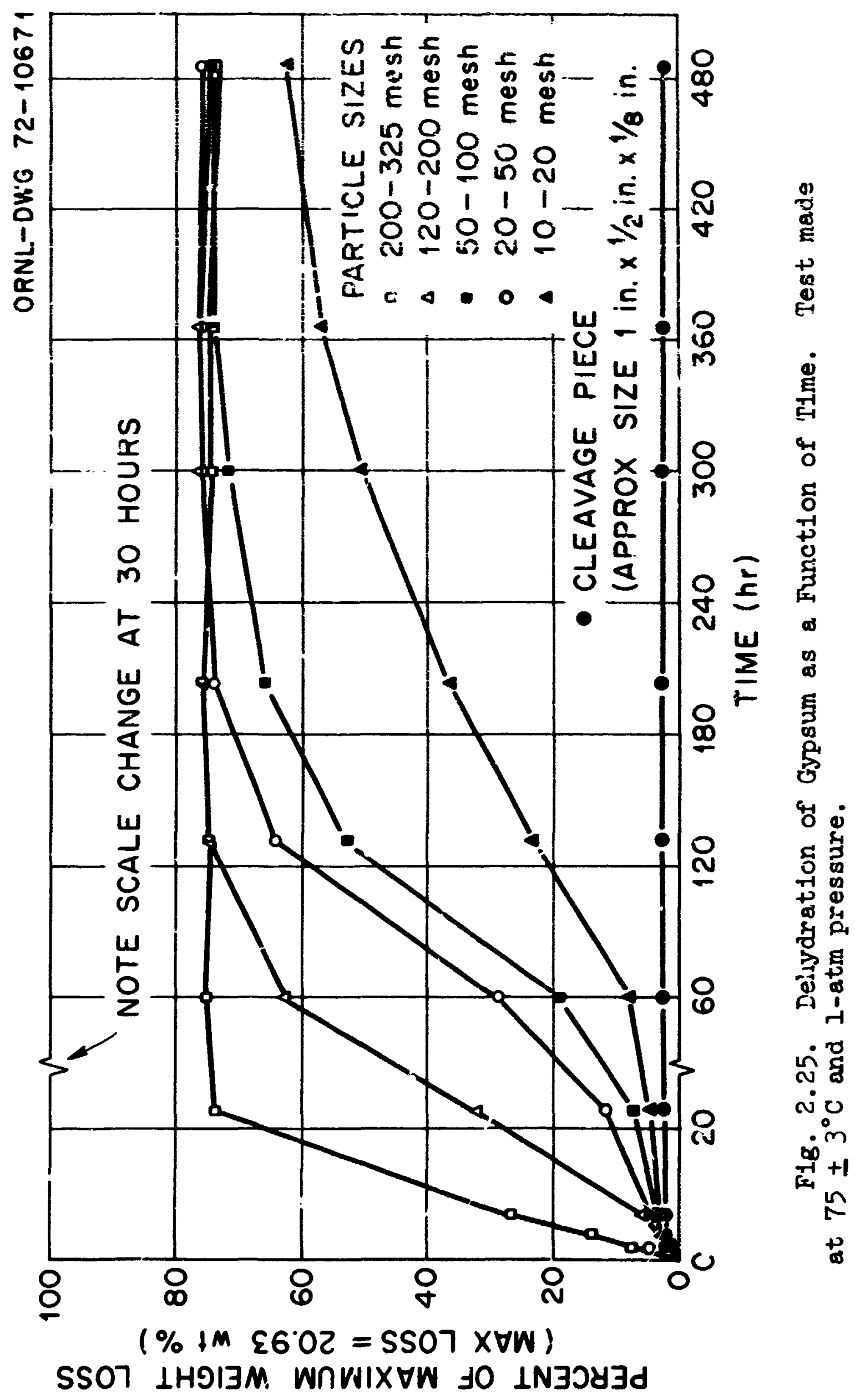


Deptin (ft)

$$
305.7
$$

426.5

542.8

674.5

1034.4

122.8 .0
Neight Loss (\$)

$$
\begin{array}{r}
15.5 \\
19.0 \\
14.5 \\
8.0 \\
1.1 \\
2.8
\end{array}
$$

To limit the probability of errors, it is necessary to use representative sample splits taken from ccres wich do not appear to have been affected by the drilling fluids or reactions that might have taken place during storage. Naturaily, these weight loss determinations will not, by themselves, indicate the precise sources of the water (e.g., gupsum, clays, other hydrated minerals, fluid inclusions, intergranular films, etc.). Not enough data are available yet to draw firm conclusions. As anticipated, there is a decrease in the amount of jehydration srater wth increasing depth. The nearly 36 weight loss from the sample below a depth

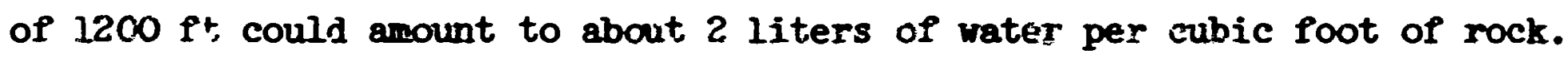

It must. be exphasized that all these tests have been performed at atmospheric fressure, while the geologic materials in situ will be heated under the confining pressures existing at their respective depths. The effect of confining pressure on tine phase change of hydrous minerals and on the thermally induced dewatering of rocks is an fmportant point deserving further consideration.

Fifty-five specimens were selected from the core from ABC Hcle No. 1 and slabbed in preparation for the cutting of oversized thin secsions. The slabs were sent out to a laboratory that specializes in tb: preparation of petrographic thin sections. These sections will be studied as soon as they are returned.

Abnorms.l Pore Fluid Pressures. - Under narmal conditions, water contained in the pores or fractures of rocks is under a prisivure equal to the weigh; of a column of water extending from tue depth considered to the top of the saturation zone. Assuming the top of the saturation zone to be coircident with the surface (practically true in most cases), the normal or hydrostatic iressure ranges frcm 043 to about 0.47 psi 
per foot of depth, depending on the salinity of grolind water. Any water grassures different from the hydrostatic value are considered abnormal; abnormal pressurtes can be lower or higher than hydrostatic. Abnormally high pressures are more frequent and are the only kind that will be discussed below.

Abnoriral pressures can exist cnly in formations that are effectively isoiated Irom the zones of circuiating ground water. The seal is usliaily formed by very impermearle argillaceous sediments or by beds of rock sait; occasinnally the sealing formation is constituted by massive beds of anhydrite, limestone, or dolomite. Several possible causes of high formation pressures are cited in the lite:ature:

(1) Aquifer head.

(2) Rate oi sediment accumulation in excess of the rate of fluid escape from the compacting sediments.

(3) Tectonic deformation.

(4) "Fossil" pressiures (corresponding to a previous greater depth of burial).

(5) Infiltration of hydrocsrbons or magmatic fluids.

(6) Osmotic phenomena.

(7) Phase changes, for example, transformation of gypsum to winydrite plus water or transformation of hydrated clay minerals to dehydrated minerals plus water.

(8) Chemical, ree:utions.

(9) Precipitation of minerals with an attendant change in pore volume.

Aquifer head is the cammon and well-understciod cause of water pressure in artesian aquifers; only cases of abnormal pressures that cannot be explained by artesian conditions will be cisnisidered below.

In the United States, abnormal press'mas bave heen observed in the Gulf Coest region (most frequently occurring at depths of 8000 to 12,000 $\mathrm{ft}$ ), in the Cenozoic basins of California (at depthis ranging from 200 
to $14,000 \mathrm{ft}$ ), in the Paradox bas in of Utah and Colorado, and in various other areas. 70,71

Invercus occurrences have been reported outside of the United States, especially in thick clayey sequences of Cenozoic ages. Abrormal pressures have been observed at a depth of only $1000 \mathrm{ft}$ in Pakistan. 72

The oil industry has accumalated considerable experience with the occurrence of abnormal fluid pressures. Usually, abnormal pressures are observed in clayey beds or in sand lenses totally enclased in argillaceous formations, especially in sedimentary basins of Cenozoic age. A few cases of abnorwal pressures in ancient rocks, Mesozoic and eren Paleozoic, are known, out they are aiways associated with sealing formations of exceptionally low permeability. This indicates that abnormal pressures are geologically transient phenomena and, therefore, that they mast bis associated with hydrodymanic conditions; however, when the sesing formaitions are very impermeable, the abnormal pressures can be retained for periods as long as several mundred million years.

In the sediventury sequences where abnormal pressires are observed, rates of sedimentation are high and permeability, especialiy anross the bedding, is very low. Under these conditions, the rate of escape of connate fluids from conpacting sediments is less than the rate of sediment accumulation; conseniently, the trappea fluids prevent compaction and support part of the weight of the overburiden.

In deposits characterized by normal Iluid pressure, the bulk density of shales is inver:seily proportimal to the porosity aid increases directly with the depth of burial. Tigure 2.26 sliows soue average relationships between shale density and depth in different areas.

If we assume that an ideal sealing formation with zero permeability is present in a sedimentary sequence, no fluids could escape from the underlying units and no compaction would occur; hence $\lambda$, the ratio between fluid pressure and overburden pressure, would be equal to 2. Figure 2. 27 shows the relationships between depth and porosity for various values of $\lambda$ in an average shale. Cases in whili $\lambda$ has a value very close to 1 have been reported in the literature. It seems reasonable tisat a value of I 


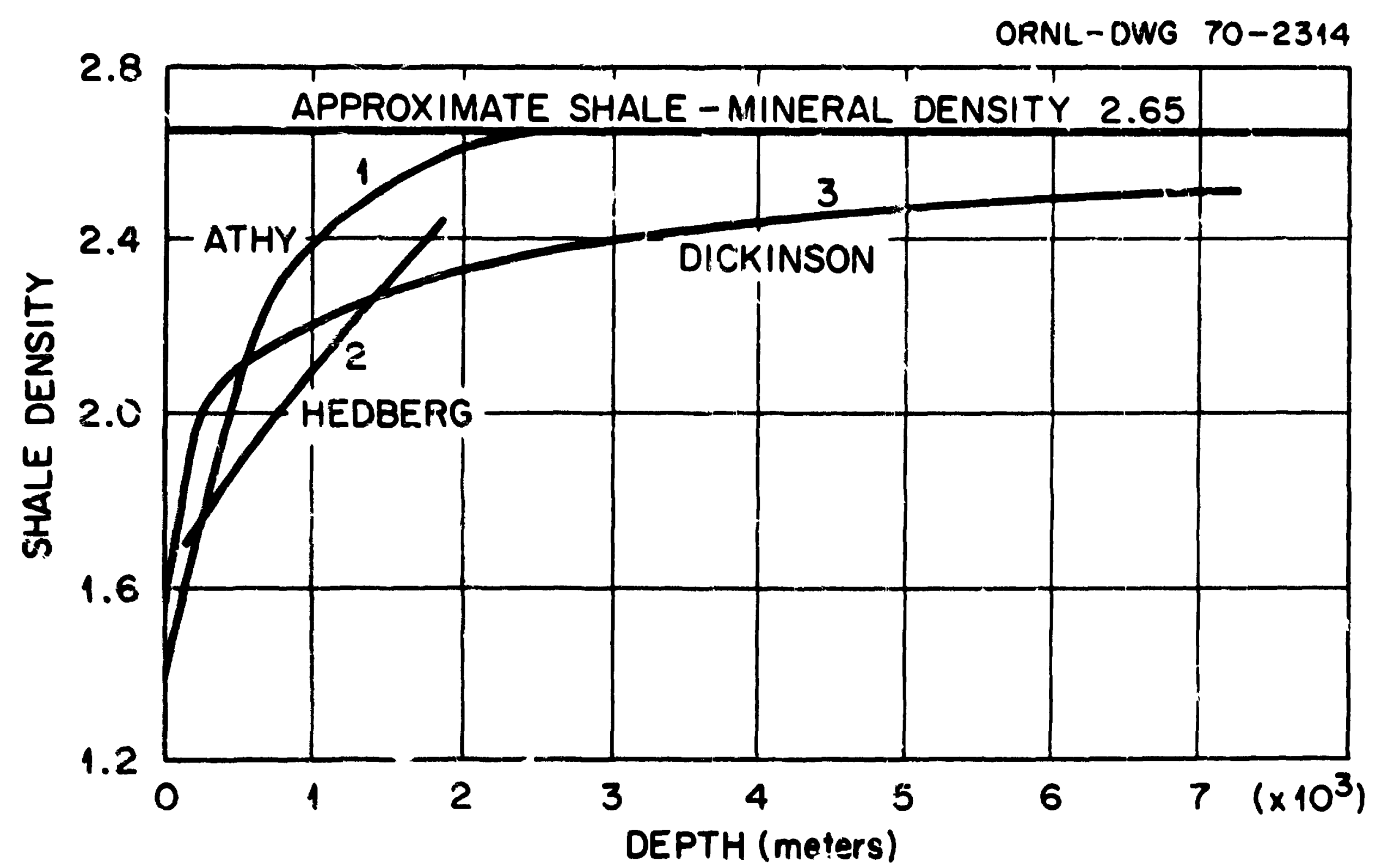

Fig. 2.26. Averace Relationships Betrioen Shale Density and Dejpth. Curve 1-r.determined by Athy for Paleozolc stialns in Oklohoma; curve 2-determined by Hedberg for Paleozolc shales in Kansas; curve 3--determined by Dickinson for Cenozolc hales in the Gulf Coast Area. 


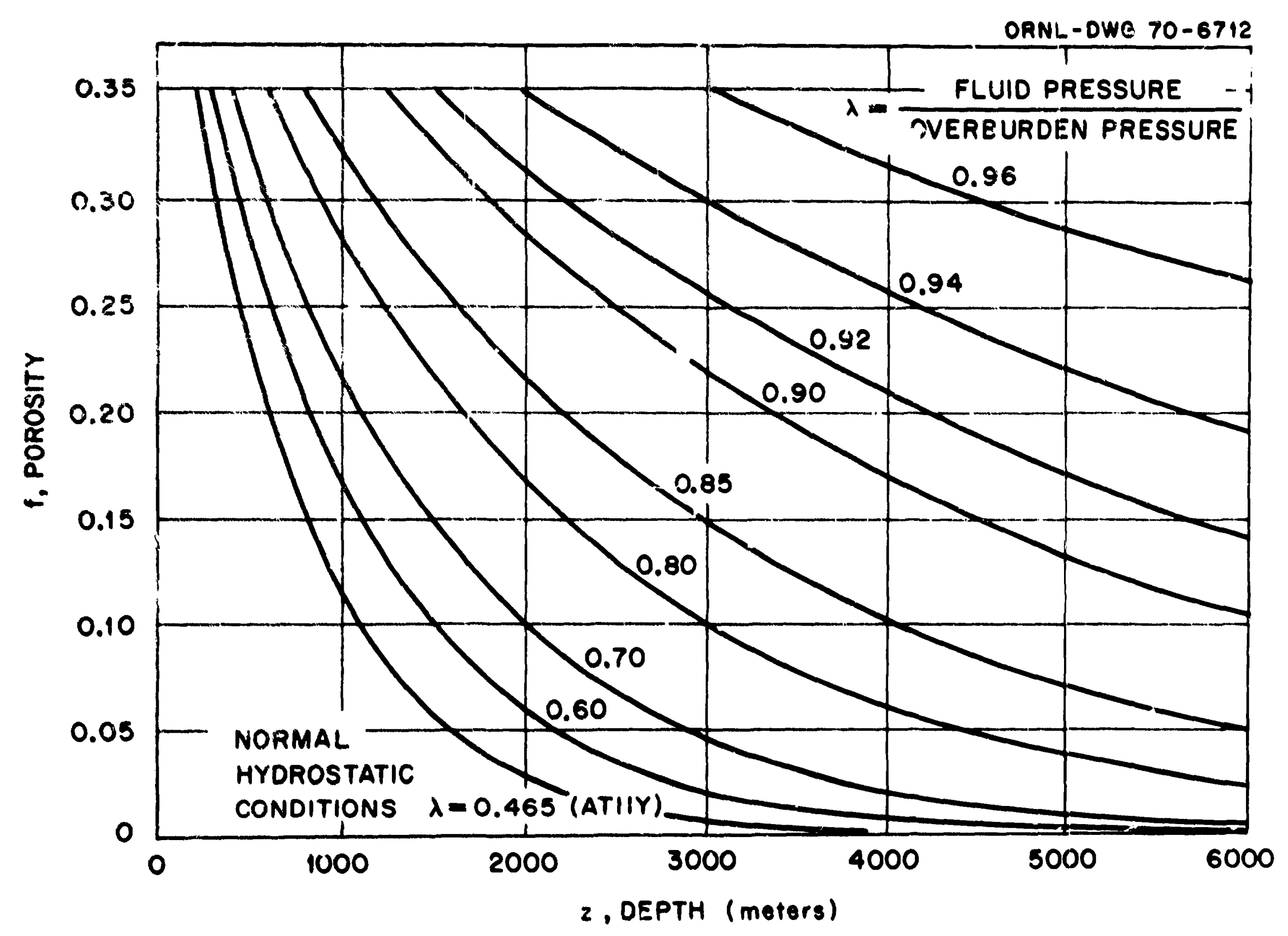

Fig. 2.27. Mutual Jelationships of Depth, Porosity, and Fluid Pressure.Overburden Ratio in an f.verage Tha le or Mudstone. Athy's curve is sssumed to represent the condition of "compaction equilibrium." 
for $\lambda$ represents a limit condition; if fluid pressures in excess of geostatic pressure were achieved because of tectonic compression, overburden removal, or other mechanisms, the fluids would either uplift the overburden, thereby decreasing the density of the overpressured rousation, or fracture the sesing zone. It follows from the above discussion that overpressured shales are undercompacted in relation to their depth and, therefore, are characterized by high plasticity and iow density. As a result, orerpressüed shales are potentiai diapiric material; in fact, many masses of diapiric shales have been identified in the Gulf Coast region. In many instances, shale masses are intruded along with salt to form a single diapiric core; in other cases, salt or shajes are the only intrusive mater:al. 73

Many geologists maintain that, in addition to the rapid rate of sedimentation over a sequence of sediments of very low permeability, other mechanisms must be invoked to explain the genesis of abnormal pressures. Frequently proposed alternatives are asmotic phencena and the transformation of swectite minerais to the interstratified layer arrangement of illite and smectite.

Shale beds are known to behave as semipermeable nembranes and, in wany cases, pore waters in shales and sands are characterized by variable salinity; thus osmotic processes mast take place in most sedimentary basins where abnormal pressures are observed. However, osnotic phencmena must constitute a secondary factor since they cannot, usually, ascount entirely for the observed pressures.

The diagenesis of argillaceous sediments with transformation of smeetite to illite and mixed-layer clay minerals is well known, and is documerited by the abundance of montmorillonite in Cenozoic narine clars as well as by its progressive reduction with increasing age and depth of burial; however its relevance to the genesis of abnormal pressures is, at the least, controversial.

Recently reported experiments in wich semples of natural and pure sprayed-dried sodium montmorillonite were saturated with di.tilled and simulated sea water and then tested with varicus chemeal solutions before 
being compressed at pressures irom 1000 to 200,000 psig, under pH conditions from 0.5 to 13 and at temperatures up to $193^{\circ} \mathrm{C}$, have failed to shor any modification of the clay minerals structure. 74 The duration of these experiments rarged from 7 to 21 days; therefore, a large uncertsirty is we to the time factor.

To date, very few mineralogical analyses of clays in the abnormal pressure zones and in the overlying transition and normal zones have been published. Some of these studies seem to indicate that changes in clay mineralogy often coincide with the top of the high-pressure zone. The sienificant change reported is a decrease in expandable clay minerals like monimorillonite, accompanied by a relative increase in nonexpandable clay minerals like illite and chlorite. 75

Experimental determinations of reaction rates for significant transformations in the diagenesis of expanable clay minerals have been recentiy repcrted in the interature. 76

The following two resitions are probably significant:

(1) $\mathrm{K}$ beidellite $\rightarrow$ illite/beid. + kaolin + quartz

(2) $\mathrm{K}^{+}+\mathrm{K}$ montmorillonite $\rightarrow$ illite/mont. + guartz $+\mathrm{H}^{+}$

The reaction rates indicate that, at $70^{\circ} \mathrm{C}$, reaction (1) would form an illite/suectite with $65 \%$ illite layers in abcut 25,000 years; et the same temperature, reaction (2) would achieve the same result in less than 10 years. If these reaction rates are indicative of actual rates during diagenesis of the argillaceous sediments, the crosition of naturally occurring illite/smectite should always be in equilibrium with the diagenetic enviroment.

In conclusion, snectite minerals undergo transformation to mixedlayer illite/smectite and the rate of the reaction is directly proportional to the teuperature. During the transformation, interlayer water is mobilized and released to the pores of the sediment. However, the relevance of the process to the genesis of abnormal pressures is unknown. There is aple evidence to indicate that the water held directly on the surfaces of the clay particles is in a physical state different from that of ilquid water. The film of nonordinary water is best developed on the 
basal plane surfaces of the expanding-lattice minerals of the smective group. Consequently, in argillaceous sediments, water in pores rivuld be liquid water, wille adsorhed vater would be in a nonliquid, probably quasi-crystalline state. 77

Transfer of water molecuies from the organized errangement of the interiayer water to the liquid water in the pores would result in an increase in pore pressure only if the density of adsorbed water were greater $\operatorname{tinan} 1$. The problems :elatije to the density of adsorbea water are particularly significant; infortunateiy, this is the subject of substantial controversy. Jensity values as 1 ow as 0.73 and as high as 1.7 have been reported in the literature. Results of some of the more reliable experiments sean to indicate a density for adsorbed water on snectite surfaces of the order of 0.97 to $0.98 .^{78}$ If this is the case, the diagenesis of smectite minerals would have no $\in$ ffect on formation pressures.

In conclusion, it is obvious that the genesis of abnormal pressures is a complex phenomenon; many factors, not reciprocally exclusive, may be responsitlc; however, the occurrence of an impermeable seal in a zone of progressive compaction is a necessary and, probably, sufficient condition.

\subsubsection{Rock Mechanics Analysis}

In any fill-sized waste repository, the salt formation and the surrounding rocks, especially those overlying the disposal horizon, will be subjected to a sequence of transient and fermanent displacements and strains. These deformations will result from the combined effects of: (1) the designed closure of the mine openings, during which the plastic creep deformation of the support pillars, acceleraled by the elevated temperatures, will allow the rocm ceilings tc rest on the backfill salt, eventually reconsolidating and recrystallizing it; and (2) the bulk thermal expansion and induced thermal stresses caused by the transient temperature ilcrease in the rock mass. The objective of the rock mechanics analyses is to provide an estimate of the magnitude of these deformations and an evaluation of theix influence on the natural lons-term containment offered by the geologic structure. 
The snalysis is being carrie: out in two principal parts. The first part, called the sememirical analysis, consists of a computer model simulating, in three dimensions, the mechanical behavior of a repository area as it is loaded with waste over a given time span. This model is called semiempirical because the in-siti mechanical and deformational property parameters of the model. are determined by correlation $\mathrm{w}^{*}$.th deformations actually measured during the Project Salt Vault experiment. Because of the large size of any actual repository and the nature of this model, it is not possible to utilize a detailed geologic column and properties for the various rock types involvori. Furthermore, the calculated deformations cannot be rigorously intercreted; instead, this model yields only the general outlines and shapes of the total deformations and serves to identify those areas which experience the most severe conditions.

The objective of the secord part of the analysis, the finite-element modeling, is to provide the details of the displacements and strains in the areas of interest. In these two-dimensional calculations, the details of the geologic section are modeled more realistically, taking into consideration physical properties of each rack type as determinel by laboratory tests conducted on core specimens.

Semiempirical Nodel. - As a part of the analysis of the Project Salt Vault experimental results, a two-dimensional analysis of this type was carried out anci is described in Sect. 13 of okNL-4555.79 As the first step in the current effort, this earlie: analysis vas enlarged to three dimensions and otherwise $g$ eneralized and then recorrelated with the deformations measured during the experiment at sycns, Karsas (Project Salt Vault). The correlation was performed by modeling the five-rocm exparimental area in 5-ft-square elements and sequencing both ihe excavation of each of the rooms and the power history of individual heaters. The "seam closures" calculated at eight of the segments were then compared with the vertical mine convergence occurring at those locations, as measured during the experiment. Based on the comparison, a different set of physical property parameters was chosen and the process was repeated. Figures 2.28 and 2.29 show the ccomparison of the sidel and measured convergence for the run which was ccnsidered to be an adequate correlation. Figures of this type 


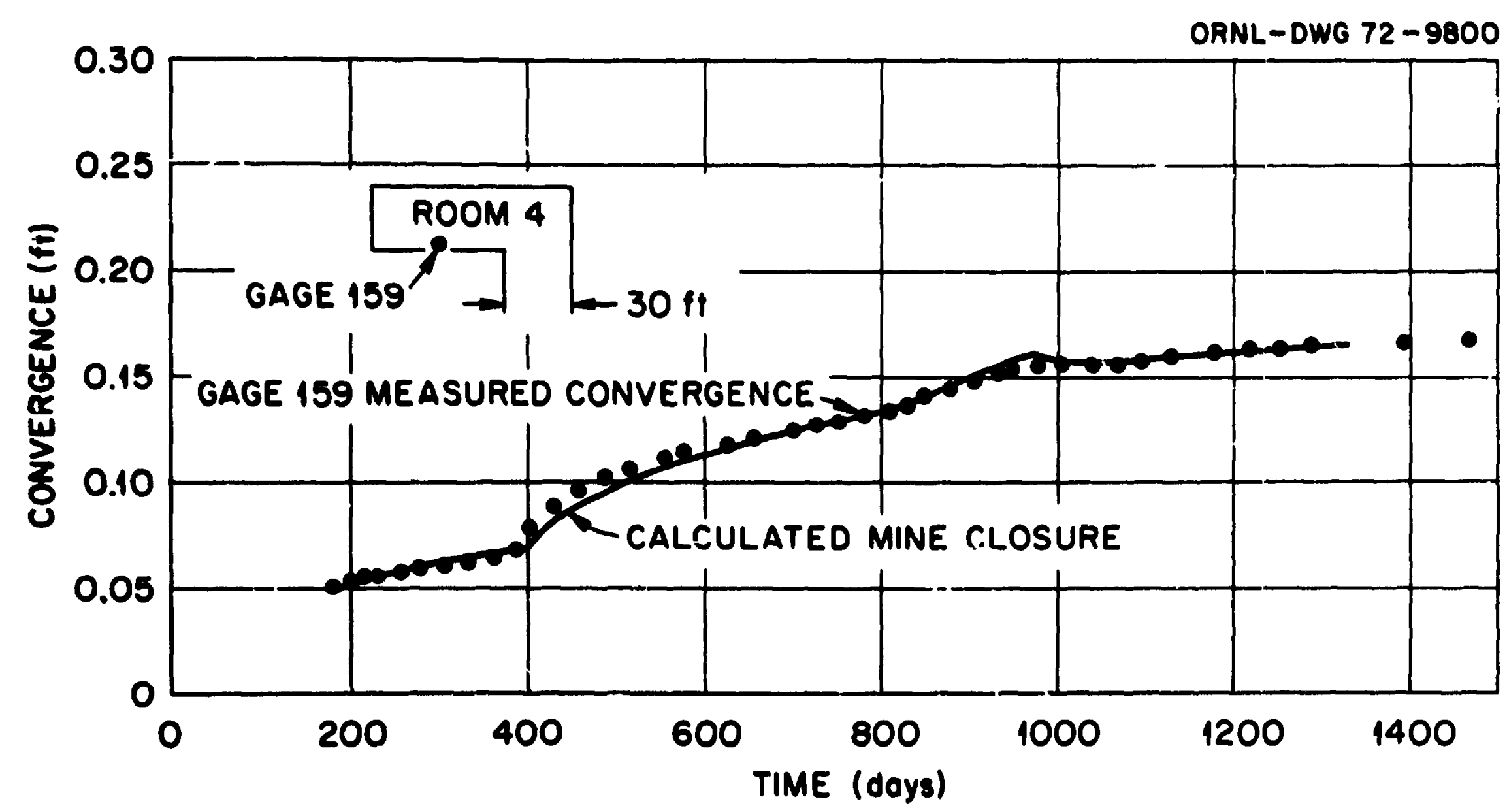

F1g. 2.28. Comparison of Measured Convergence with Calculated Mine Closure. 


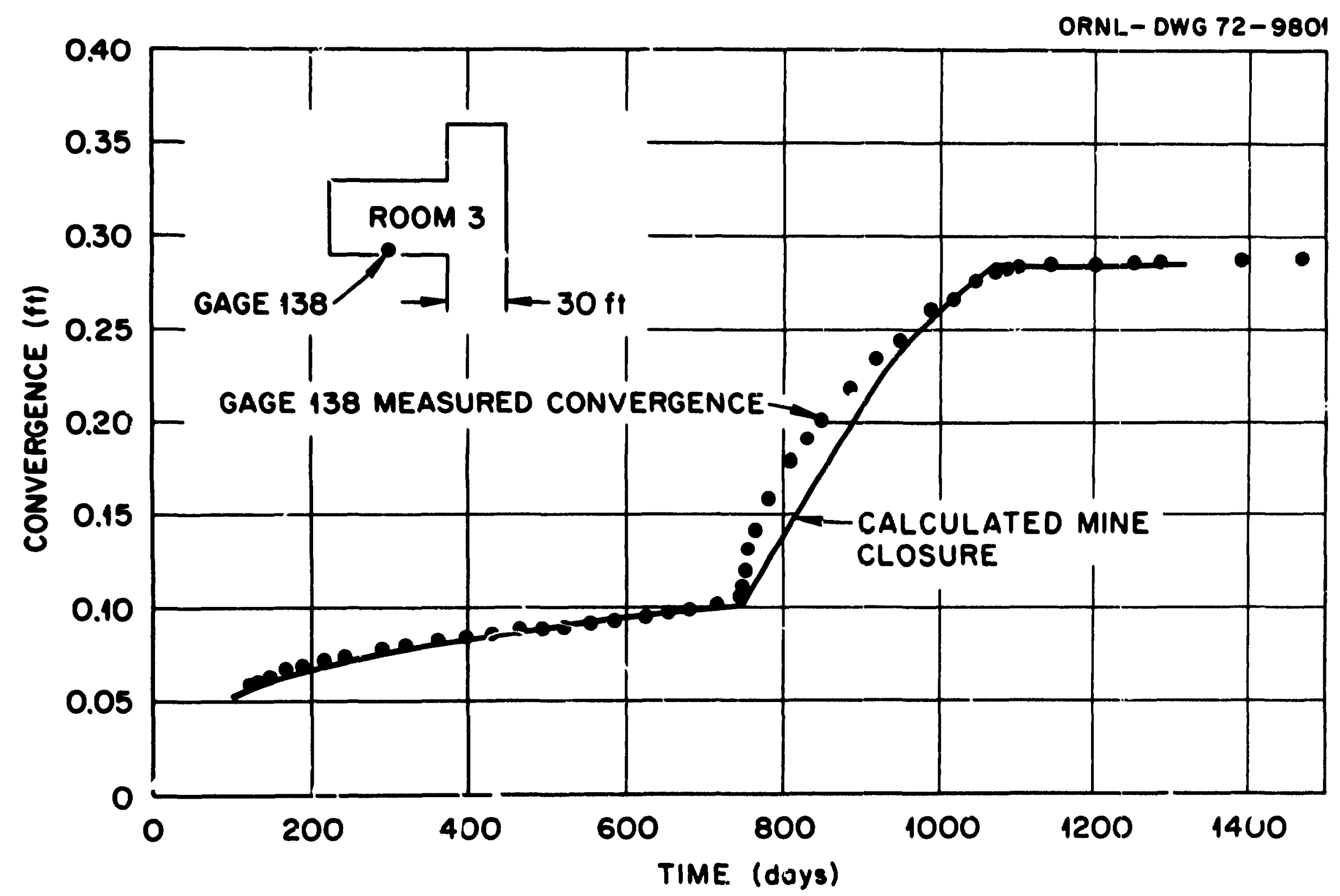

F1g. 2,29. Comparison of Measured Convergence with Calculated Mine Closure. 
are obtained for each of the eiglit points. The values of the physical property and model parameters used in this "correlated" run are given in Tatie 2.9. Both the 2-D model and the 3-D model are based on a creep deformation law obtained empirically by Lomenzck, 80 who found that:

$$
\epsilon=1.3 \times 10^{-37} \sigma^{3.0} \mathrm{~T}^{9.5} \mathrm{t}^{0.3} \text {. }
$$

It is interesting to note that "correlation" creep parameters obtained for the $3=D$ model are closer to these values than were earlier optained for the 2-D model.

This model is currantly being use 3 to develop data for comparison with the finite-elenent aralysis and in a parametric analysis of the small area to be used as a pilot plant. Efforts are also currently in progress to drastically extrapolate this model, with respect to both space and time, so that the evaluation of actual repository operations can commence.

Finite-Element Analysis. - This portion of the anelysis is divided into three parts: (1) laboratory determination of the rock property parameters required for imput into the finite-element models, (2) thermal elastic-plastic finite-elenent modeling of the repository site rocks, including simulated excavation, heat sources, and backfill compaction, and (3) thermal viscoelastic finite-element modeling of the repositary site.

Experimental Results. - Specimens prepared from the core obtained at the Lyons site were analyzed in these tests in order to provide realistic values of the physical property parumeters used in the mathematical models and to confirm and refine the testing techniques and equipment. As soon as core material from the selected site becosas avaliable, a more extensive series of laboratory tests will be conducted. Simple-compression and indirect-tension tests made at rocm temperature and atmospheric confining pressure have been completed for samples from five of the nine rock layers to 2 depth of $1290 \mathrm{ft}$. Creep experiments, in simple compression and at room temperature and atmospheric confining pressure, have buen completed using samples of Ninnescah shale and Hutchinson salt. 
Table 2.9. Hodel Parameters

\begin{tabular}{|c|c|c|}
\hline Definition of Parameters & $\begin{array}{l}\text { Value in } 2-D \\
\text { Correlation }\end{array}$ & $\begin{array}{l}\text { Value in } \hat{3}-D \\
\text { Corr }=\text { lation }\end{array}$ \\
\hline $\begin{array}{l}\text { Elastic modulus of roof and floor } \\
\text { rock, psi }\end{array}$ & $10^{6}$ & $10^{6}$ \\
\hline Poisson's Ratio of roof and floor & 0.4 & 0.4 \\
\hline $\begin{array}{l}\text { Initial ambient temperature at } \\
\text { mining, }{ }^{\circ} \mathrm{K}\end{array}$ & 300 & 300 \\
\hline $\begin{array}{l}\text { Wean thermal horizon diffusivity } \\
\text { in vicinity of heat sources, } \mathrm{ft}^{2} / \mathrm{hr}\end{array}$ & 0.1 & 0.1 \\
\hline Premining vertical stress, psi & 1000 & 2000 \\
\hline Elastic modulus of pillar, psi & $1.5 \times 10^{5}$ & $10^{6}$ \\
\hline \multicolumn{3}{|l|}{$\begin{array}{l}\text { Coefficients in creep equation } \\
\left(c=A \gamma_{T} b_{t}{ }^{c}\right)\end{array}$} \\
\hline A & $0.65 \times 10^{-36}$ & $0.65 \times 10^{-37}$ \\
\hline $\mathbf{a}$ & 3.0 & 3.0 \\
\hline b & 9.5 & 9.5 \\
\hline c & 0.37 & 0.25 \\
\hline Pillar height, ft & 14.0 & 14.0 \\
\hline Half widin of elements, ft & 2.5 & 2.5 \\
\hline Length of time steps, $\mathrm{hr}$ & 120 & 600 \\
\hline
\end{tabular}


A campilation of the overall physical-property data obtained to date finm the tesiing program is presented in Table 2.10. A note of caution is rdvised in evaluatine these rock parameter values on an absolute basis since sufficient test results are not available at this time to asses: the statistical scatter of the data and to establish confidence limits. The experimental results obtained thus far are only preliminary in nature and simply serve to provide guidelines for quantitative ievels of parameter magnitude. It must aiso be notea that the core samples obtained for testing were subjected previously to severel freeze-thaw cycles. The influence of freezing and tharing on the mechanical properties of rock is difficult to iscertain quantitatively; however, from a qualitative viewpoint, an overall loss of "competence" in the rock structure would be suspected, particularly for the more porous rock and for shales containing entrepped water and swelling minerals. Some of the shale samoles obtained for testing exhibit swelling and are, in general, somewhat friable and fragile.

The procedure for p:eparing the test samples proved to be quite time-consuming. In general, 2-in.-diam samples were dry-cored normal to the bedding planes from split-segments of 6-in.-diam core. The compression samples were cored to a nominal length of 4.5 in.; the ends of the sample were initially trimmed with a diamond saw (under dry conditions) resulting in a nominal length of $4.2 \mathrm{in.}$, and then dry ground in order to achieve parallel ends. During both the coring and grinding processes, core breakage along a bedding Jlane frequently occurred; the broken cores were either abandoned or salvaged for tensile specimens. A tensile specimen consists initially of a 2-in.-diam core, approximately 2.5 in. long. The ends are trimed with a diamord saw (under dry conditions), resulting in a nominal le:gth of 2 in., and then hand-lapped on a grinding wheel. Fumerous core samples, with a diameter of 0.75 in., were cut parallel to the bedding for the future assessment of anisotropic rock parameters.

As mentioned previously, all tests were conducted under conditions of room temperature and atmospheric confining pressure. In the compression tests, both short-time and creep, the core samples were loaded uniaxially, perpendicular to the bedding plares. Axial strains during loading were monitored by two strain gages, positioned along the axis of the core and 
Dable 2.10. Fhrelcal-Projurty Date Cor Rock at Irom 81te

\begin{tabular}{|c|c|c|c|c|c|c|}
\hline \multirow{2}{*}{$\begin{array}{l}\text { Depth } \\
(s t)\end{array}$} & \multirow[b]{2}{*}{ sook Dpe } & \multicolumn{2}{|c|}{ Stat10 Peatic Proportiee } & \multicolumn{2}{|c|}{ Stat10 Otrenth (og1) } & \multirow{2}{*}{ 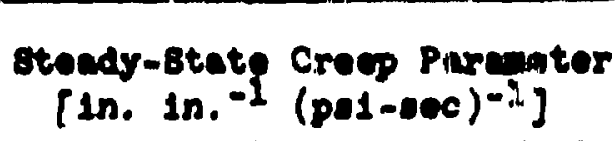 } \\
\hline & & $8\left(10^{6} p 01\right)$ & Po1eson': Rat10 & Compreseston & Toneion & \\
\hline $0-70$ & $\operatorname{Cr} \alpha(20 \times n)^{\circ}$ & 0.25 & 0.3 & & & \\
\hline R-170 & 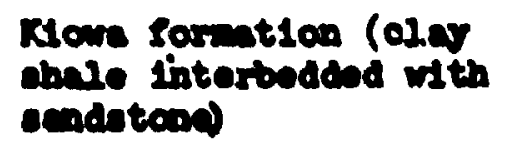 & & & & & \\
\hline $17-893$ & 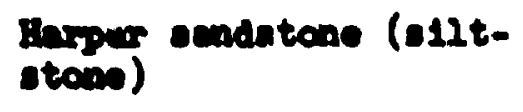 & 0.5 & 0.2 & 2600 & 270 & \\
\hline $896-315$ & $\begin{array}{l}\text { Atome Corral (dolonite, } \\
\text { anhyterite) }\end{array}$ & 5.8 & 0.34 & 3500 & 180 & \\
\hline $326-630$ & monosean obelo & 0.6 & 0.2 & 2100 & 290 & $2.85 \times 10^{-12}$ \\
\hline $631-815$ & Mllington shale & & & & & \\
\hline $316-100 n$ & Sutchineon oult & 0.4 & 0.4 & $8: 200$ & 350 & $0.84 \times 10^{-12}$ \\
\hline $1 \cos -1250$ & $\begin{array}{l}\text { Millington formation } \\
\text { (anhydrite and ahale) }\end{array}$ & & & & 770 & \\
\hline $2851-1290$ & $\begin{array}{l}\text { Moland formation - } \\
\text { larrington nobr } \\
\text { (dolondte, 21mostono) }\end{array}$ & 3.3 & 0.32 & $2 \times 100$ & 700 & \\
\hline
\end{tabular}

Ararege value evallable in the literature. 
iianetrically opjosite of each other (to averise bendiug effects); ir addition, furing the creep tests, the rial displacenest if eacil sore sample was measure 3 by means of a pair of DiDT tzansducers. In the conpression test, the circunferential or lateral strains of each saple durine laading were peasured by two strain bages, Joritioned on the circunference of the core dianetricaily opposite to esch sther, The tensile strength of rock sample was obtained indirectly by means of the Brazilian test. Diametrically opposite line loads were apiled on the circunference of a core, parailei to its axis, and the tensile strength was calculated from the load at fa:lure and the saple dirensions.

In general, the compressive and tensile strengths of the various zembers were less han gnticipated, particularly for the Stone Corral. Prom the viewpolit of quantitative ouideintes, the compressive strengths of the liarper sandstone, Hinnescah shaie, and the Hutchinson salt are of the order of $2500 \mathrm{psi}$, with tensiie strengths ranging from 200 to $400 \mathrm{psi}$. The compressive and tensile strengths of the Stone Corral appear to be of the order of $3500 \mathrm{psi}$ and $500 \mathrm{psi}$ respectively. The ne-bers below the Ihtchinson salt exhibit compressive strengths of the order of 5000 to $6000 \mathrm{psi}$ and tensile strengths ranging from 700 to 800 psi. It mot be emphasized that these values are preliminary and subject to revision and statistical clarification, pending the recults of additional tests. In each instance, the rock sample did not fail violently but, instead, developed localized cracking with subsequent cmishing and compactinn.

Thermal Elastic-Plastic Finite-Blement Model. - A note of caution is advised with regard to the absolute interpretation of the numerical results presented in this and the next sections. Although $t$,e analyses are mathematically sound (being based on the fundamenial axions of mechanics), the ccmputed results are only as good as the assumed stress-deformation laws and the physical-property data input. To date, the results obtained experimentally in the leboratory are only prelimi1.3ry, thus serving merely as guidelines for the selection of appropriete constitutive relations and for quantitative estimates of the magni.tudes of rock parameters. By the same token, the computer results must be 
regisded from ofie of a quiftative thas a quantitative viewpoint. The essential features of the mechanical behsvior of the repository site can be disinguished, and perheps brsinatsed, by calculations based on reasonable estimates of the extree variations in the values of the rock parameters for relatively single consticutive laws. The refinenent required for ipproved gaentitative fuignents is directly related to the scope of the laboratory testing program.

The elsetsc-plestic abajofis has been directed prinarily toward an evaluation of Fariations in the values of the nodali of elasticity and the tensile and compessive strengthe of the rock méts; in confunction with the nuber of roons in a row on the wine level, as regards the strest behavior for short tine periods. Two finite-elenent nodels bxve been explosed for seren protuction runs for the purpose of assessing the effects of mesh size, nuber of roons, and rariation in materias properties on the elastic-plastic states of stress and deformation in the repository site. The first is a relatively coerse mesh, containing 434 nodes and 807 elements, of formation. The seccond contains 875 nodes and 1683 elements, of with 1201 elements are in the sait lajer. The first iwo conputer runs on each of these models were made Por the purpose of assessing the effect of the finjte-elcant sesh size on the computations. The second wodel contains toice as wany elements as the first but, wore iportantly, has approxinately three tines the muber of eienents in the salt laver in wich the room is situated. Bach nodel contained a single room. The maximan surface subsidence predicted by both models is the same $(0.001$ in.), and the naximm closure predictions for the rcas are within reasonable agreement ( 0.073 anc $0.089 \mathrm{in}$. respectively). The latter difference is probably caused by mumerical aspects of the computations. However, the smaller elements in the vicinity of the cpening in the second model reveal several elements in tension, whereas the larger elewents of the first model obscure the stress gradient near the roof of the roon as evidenced by the lack of tension. A slight tension should, in fact, be present.. Thus, a coarse mesh appears satisfactory for displacement cuicuiations, but a refined mesh will be required for stress andiysel. 
The influence of the nuber of roris or stress and deformation fields was exanined on the basis of three production runs ith the second, swall-elewent oodel invoining coe, three, and five roons. Is the muber of rocus increases from ane to fire to nine, the zelatively high stress concentration in the solid salt on the outboard side of the eni room woves beyond the influence range of the $r 00$ sear the center of the modei. Fron a practical vieupoint, nine roons probably represents an infinite rou of roas; bence, the rolue of rock strate containing an one of the central roces nay be selected for detailed andysis. Bonever, there does eppear to be a trend tovard a slight expansion of the zone of root tension as the muber of room in a rou increases. The salt around the rooms does not yield plastically for either fire or nine room in a row. The vaxima surface subsidence is less than 0.002 in. for an arrw of five room and less than 0.604 in. for an arras of nine rocm; the corresponding maxion roon closmes are 0.110 in. and 0.112 in. reapectively.

Results of the co puter runs copleted luws far support the general notion that the prelininary elastic-plastic andrsis ad associated nethods of evaluation are eppropriate to the evaluation of the rock acchenics aspects of a waste repositary.

Theral Viscoelastic Finite-Elenent Hodel. - The Viscoelastic analysis has bean directed toward an eraluation of variations in ralues of the creep garaneter for the rock nebers, in confunction with an infinite row of equally spaced roces on the wine level, as regards the deformational vehavior orer long time periods. Again in this analseis, two nodels were exployed for the purpose of assessing the effects of nesh size and variations in the steady-state creep rates of the rock nebers on viscoelantic states of 3 tress and deformation in the repository site. The first is a relatively coarse nesh, containing 72 nodes and 100 eienents, of wich 33 elewents are in the Hutchinson salt formation. The second contains 180 nodes and 298 elewents, of mich 222 elements are in the salt laver. Each model represents a cross section of the site, with 2 depth of $1300 \mathrm{It}$ and a wdth of $18 \mathrm{ft}$, containing one-half of a pillar and cne-hal: of a roca; in essence, the nodel represents a colum of rock strata contrafning 
- central room in an infinite row of rooms. The stratigraphic sequence of rock lavers and correspondizs rock paraneter values are given in Table 2.10; wenever possible, the ralues of the rock paraneters were taken from those obtained in the labaratory on core fron tre furons site.

The Hscoelastic coputer code is programed to conpute both transient and steady-state creep deformations according to the linear Burger rheoIogicai noiei, vich is, in essence, a Volgt model and a Yaxrell nodel cxupled in series. However, che resuits obtained thus far periain only to stecd-state creep, as the paraneters for the loift portion of the bucger sodel vere unarailable. The caputational process is exceedingly todicus and tine-consuing, oring to the judicious process required for deterdining the proper tine increnent necessary for convergence of the calculations. Several developant ran were required for establishing bosids on the tine increnent in relation to the magnitude for the steadystate creep parmeter, as well as for establishing gaidelines for updating the tine increacent during the conputational process. Comanly, a tine increment of 0.000 jear for five to tee cyeles is required to initiate the copputations. The cholce of the inftial tf e increnent is quite inportant; too sall an increnent - Ill give rise to coputational inaccuracies due to roundoff and truncatson errors, wile too large an increnent wil cause the conputations to diverge. The tive incresint is generally updated by a factor of 2 or 5 after every five to ten cycles.

The first runs with each of the two sodels were made for the purpose of assessing the effect of the fintte-elenent wesh size on the coputations. The second nodel contains approxinately three tires as many elenents as the first. Itse coputed displacenents differ by no more than 10, for sall tine intervals, say less than 1 year; hovever, for large tine intervals the difference becones progressively grsater. The insccuracies over long tine spans occur as a result of the stress calculations, which my be exceedingly coarse for a relatively coarse mesh. The riscolastic deformations are directly related to the deviatoric stresses, and the errcr due to a ccarse calculation of the lattex propagates in an accumates fashion over a long time interval. 
The effect of a variation in the magnitude of the steady-state creap parameter on the displacement field in the repository was examined on the basis of two projuction runs with the fine-mesh model. In the first run, the value of the creep parameter for the Hutchinson salt was taken as that given in Iable 2.10, and the values of the creep parameters for the other seven rock members were assumed to be those given for the Nirnescah shale. During the second run, all values of the creep parameter were reduced by two orjers of magnitude. The sensitivity of the viscoelastic displacements to a variation in this parameter $w$; quite apparent. For a value of the creep parameter of $0.345 \times 10^{-12}$ in. in. ${ }^{-1}$ (psi-sec) ( $^{-1}$ for tise Hutchinson salt, the displacements of the roof and floor of the room are quite rapid and large, giving rise to complete closure of the room after three years. Conversely, a value of $0.8^{4} 4 \times 10^{-14} \mathrm{in.} \mathrm{in.}^{-1}$ (psi-sec) $^{-1}$ yields room aisplacements orer a period of 25 years wich appear physically reasonable (i.a., $\sim$ in. of flcor heave and 4 in. of roof sag at the center line of the rocm). These computations suggest inat complete closure of the ruom would result after 450 years. Of greater importance, however, is the fact that an accurate account of the creep defornation throughout all three stages of creep (transient, steady state, and teriary), as obtained from laboratory experimentation, is a necessity due to the sensitivity of the computer code calculations to the creep-parameter values. 


\subsection{Refererices for Section:}

1. State Highway Commission of Kansas, memorandum to R. R. Beige, Engineer of Lxation and Design. Concepts, fron Virgi?. A. Burgat, Chie: Geologist, Subje:t: "Ceology Report: Sinking Ground Along I-70 West of Russell, July 1970."

2. Frank Vincent, "Histcry of Sait Discovery and Production in Kansas, 1887-1915," Kansas State Historical Society, Vol. XIV, pp. 371-72.

3. Otto Rueschhoff, American Salt Corpcration, private communication, Aug. 30, 1971.

4. J. M. Jewett, "L. P. G. Storage in Kansas Salt Beds," pp. 91-94 in Kanc us Geological Society Guidebook, 18th Field Conference, October 1955.

5. "LP--Gas Storage Survey," Oil Gas J., p. 87 (Mar. 8, 1971).

6. C. M. Yours, "Subsidence Around a Salt Well." Trans. AIVE LOXIV, 810-17 (1927).

7. C. A. Bays, W. C. Peters, and M. W. Pullen, "Solution Extraction of Salt Using Weils Connested by Hydraulic Fracture," Trans. AIME 217, 266-77 (1960).

8. J. G. Davis and D. A. Shock, "Solution kining of Thin Bedded Potash," Mining Eng. 22(7), 106-9 (July 1970).

9. J. E. Muers, Lepartment of Geology, Wichita itste In'versily, Wichita, Kansas, private commuricaticn, May 22; 1972.

10. Otto Rueschhoff, Americar Salt Corjorotion, letter to A. L. Borh, ORNL, Nov. $22,1971$.

11. Otto Rueschhoff, American Salt Corporatial, letter to F. M. Bupson, ORN, , Yay 4, 1971.

12. Buce Latta, Kansas State Department of Health, letter to W. C. McClain, ORin, Jurie 15, 2971.

13. "Geological Report or the Suitability of Mine Cavities in the Asse II Rock Salt Mine for the Irisposal of Radiosctive Wastes," Bundensanstalt fïr Bodenforechung, Hannover, Nov. $36,1.963$.

14. J. F. Motchie and R. Silvester, "On Crustal Flexure," J. Geophys. Res. $24(22), 5240-52$ (1969).

15. Artbur Holmes, Principles of Muysical Geology, Ronald Press, Hew York, 1965. 
15. W. R. Farrand, "PC:t--glacial Uplift in North America," Am. J. Sci. $250,181-99(196: ?)$.

17. W. L. Donn, W. R. Farrand, and Maurice Bring, "Pleistocene Ice Volumes and Sea Level Lowerts," J. Geol. 70, 206-14 (1962).

16. J.-J. Holtzscherer and G. deQ. Robir, "Depth of Polar Ice Caps," Geog. J. 120(Pt. 2), 193-97 (1954).

19. J. Weertman, "Equilibrium Profile of Ice Caps," J. Siaciol. 3, 953-64 (1961).

20. R. W. Fairbridge, "Glacial Geology: Periglacial and Global Effects," pp. $440-44$ in The Encyclopedia of Geonorphology, ed. by R. H. Fairbridge, Feinhold, Kew York, 1968.

21. W. R. Farrand, "Postglacial Isostatic Rebound," pp. 884-88 in the Bncyclopedia of iecmorphology, ed. by R. H. Fairbridge, Reinhold, lieu York, 1968.

2i. R. I. Walcott, "Isostatic Response to Iooding of the Crust in Caneda," Canadian J. Earth Sci. I(2), 716-34 (1970).

23. Clifford Eubleton and C. A. M. King, Glacial and Periflaciel Gecorphology, St. Martin's Press, Mew York, 1968.

24. J. 4. Ambrose (ed.), "Syposiun on Recent Crustal Novecents," Canadian J. Earth Sci. I(?), Pt. 2, 553-734 (1970).

25. G. K. Gilbert, Lake Bonneville, U.8. Gealogical Surver Monograph I, 1890.

26. M. D. Crittenden, Jr., Lev Data on the Isostatic De?crantion of Inte Bonnevil].e, U.S. Geological survey Professional Peper 454-5, 1963.

27. H. D. Crittenden, Jr., "Hater Ioading and Crustal Reaponse," pp. 122122 in the Bocyclopedia of Ceanorptolox, ed. by R. H. Fairbridge, Reinholá, new York, 1968.

28. John Handin and R. V. Hager, Jr., "Properinental Deformation of Sedinentary Rocke Under Craflining Pressure: Tests at Boon Ie pereture on Dry Saples," Bull. M. Assoc. Petrol. Ceologises 41(1), $1-50$ (1957).

29. E. S. Hills, Elexents of structural Coolox, =iley. Few Jork, 1963.

30. H. P. Billings, 8tructural ceology, 3rd ed. Prentice-Ball, Inc., Englewood Cliffe, H.J., 19î̉.

31. B. Glass, D. B. Ericson, B. C. Beeren, A. D. Ophtre, and J. A. Glass, "Gecosagnetic Reversals and Plelstocene Chronolosy," Mature 216(5114), 437.42 (1967). 
32. R. F. FInt, "Rites of Adrance and Betreat of the Mrgin of the Latemisconsin Ice Sturet," An. J. Sc1. 253, 249-55 (1955).

33. R. F. Plint, Gacinl and Pleistocene Geolosy, Wiley, wew York, 1957.

34. R. P. Flint, Gleciel and Guaternary Geolox, Hiley, New York, I97.

35. R. E. Durrell, "Irrasion by sea and Ice" (abstract), p. 186 in U.S. Ceological Survey, Abstrects of Earth Nerican Geolosy (Pebriary 1968).

36. C. K. Bayse and J. R. Wurd, "Surfece Ceolocy and Ground-water Bydroloes," Chep. 1, pp. 4-37 in Final Beort, Geolory and Elpdrol-

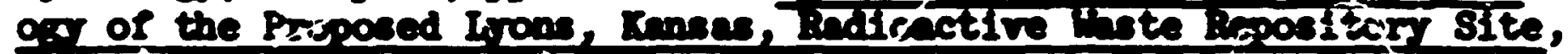
ed. is 8. E. Aogtax, W. H. Bebleton, and the stafl of the Runeses Geological surves, ine lniversity of Kanses Center for Besearch, Inc., 157.

37. E. D. Coebel, "Statw Boport of $81 \times$ Nonth Study of the Subrurface Rocks at the Proposed site for the lational Redionctive linste Repository at Iroas, Rice Connty, ransas," pp. 38-84 in Pinal Boport,

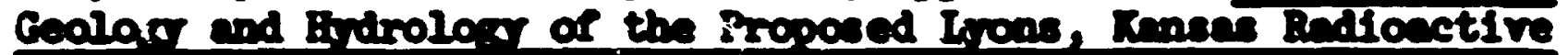

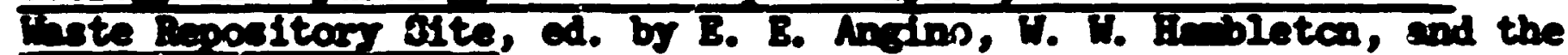

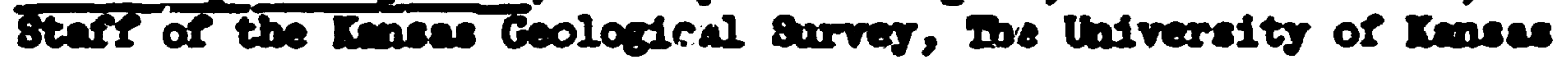
Center for Besearch, Inc., 1971.

33. M. R. Mndge and R. H. Durton, Ceoloy of Hbanmese County, Ionses, U.8. Geolocical surny Bulletin 1000, 1959.

39. H. G. O'Connor, Geoloy and Gound-weters Deopurces of Donsles County,

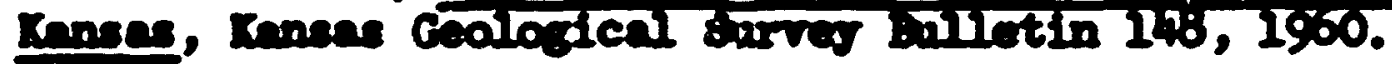

40. W. D. Johnscen, Jr., and W. I. Adrtson, Geolorv of Bastern Suamee

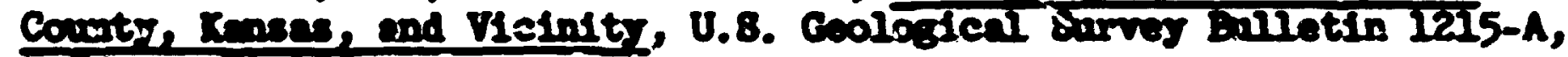
ISOT, p. 1-123.

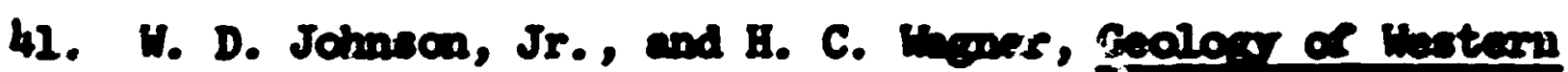

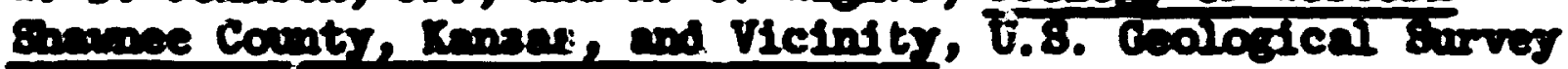
Exiretin IZI5-3, 1901, pp. I25-254.

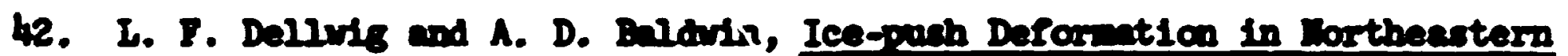

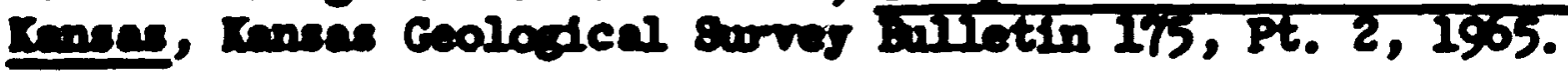

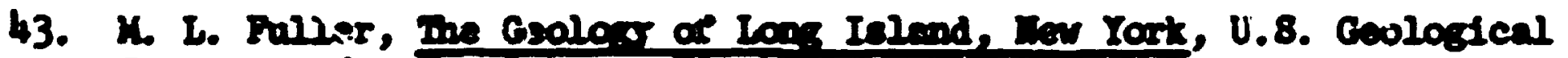
Burver Professional Paper ir, I9l4.

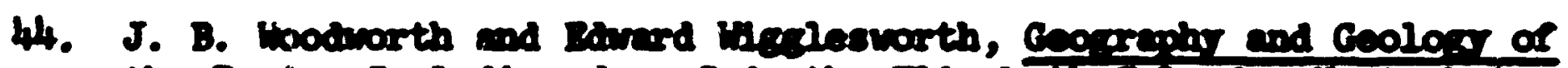

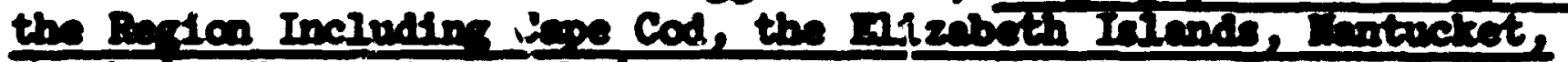

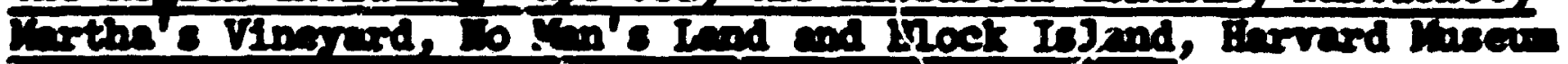
cop. 20010s, inotre, Vol. Si, 1954. 
45. C. A. Kay, IUlinoian and Barly IIsconsin Noraines of Marthe's Vineyard, Missectusetts, U.S. Geological sumrey lirofessional Peper 501,1904, pp. C134-CI39.

46. A. C. Veatch, "Outlines of the Geology of Iong Island," Chap. 1, pp. 15-52 in Undersxound Water Resources of Iong Is'and, Wew York, U.S. Gealogical Surver Professional Peper 44, 1906.

47. W. W. Rubey, Geoloxy and Mineral Rescurces of the Hardin and Brussels Guadrangles (in Illinois), U.S. Geologinal Survey Professional Paper $216,1952$.

48. Jac Oliver, Tracy Johnson, and Janes Dorman, "Post-glacial Feulting and Seisicity in Iew York and Quebec," Canadian J. Barth Sc1. I(2), $579-90$ (1970).

49. P. R. Lamerson and I. P. Delluif, "Deformation by Ice Push of Ifith1Iled Sediments in South-central Iowe," J. Geol. 65(5), 546-50 (1957).

50. J.-J. Holtzscherer and ilbert Buer, "Contribution a la comsissance de l'inlandsis du Grxenlan. Pt, 1 . Meswres selendques par JeanJaques Holtzscherer. Pي. II. Synthese glacialogique par Albert Barer," linion Geodesique et Gemphrsique Internationale, Assoc. Internat. Hodral. Scientifique, Asemble Generale de Bome 1954 4, 244-96 (2956).

51. Whan Barrison, "Marginal Zones of Vanished Glaciers Reconstructed from the Preconsolidation-Pressure Values of Overridden silts," J. Ceol. 66(1), T2-95 (1958).

52. Ferruccio Cera, "A Review of Salt Tectonics ir Relation to the Disposal of Radioertive lastes in Salt Formations" (to be publisbed in the December 197 ? issue of the Bulletin of Geological society of Anerica).

53. D. E. Hattin, personal comunication, 1971.

54. W. C. Gusson, "Salt Diepirian: Inpotance of Temerature, and Deeres Source of Bplacenent," pp. $16-52$ in Diepirie and Diepirs, A 8Loosiv, ed. by J. Brwunstein and G. D. $0^{\prime}$ Brien, Anericen Association of Petrolew Geologists, Tulse, Orla., 1968.

55. R. E. Taylor, "Structure Work 8essions," pp. 663-70 in Ealine De seits, A Szoosivn Based on Pepers Iran the International Conference on saline Deposits, Houston, Texas, Geslocical society o: merica Special Peper 68, 1962.

56. H. A. Correll and G. R. Alderman, "Hk Point Froup Baline Basins of Alberta, Saskatchewan, and Manitoba, Canada," pp. 391-317 in 8aline Deposits, A 8Lopiun Based on Fepers from the International Conference

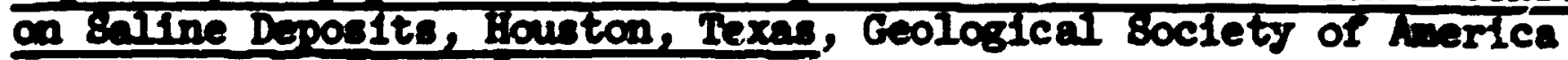
Epecial Peper 86, 1962. 
57. C. H. Jacoby, "Correlation, Faulting, and Metamorphism of Michigan and Appeiachtan Basin Salt," Bill. Am. Assoc. Fetrol. Geologists 53(1), 136-54 (1969).

58. G. E. Murray, "Salt Structures of Gulf of Mexico Basin--A Review," Bull. Am. Assoc. Petrol. Geologists 50, 4j. 78 (1966).

59. R. J. Hite, "Salt Deposits of the Paradox Basin, Southeast Utah and Southwest Colorado," Geological Society of America Special Paper 88 (2968).

60. K. K. Turekien (ad.), Iate Cenczo:c Giaciai pges, Yale University Press, Hew Haven, Conn., 2971 .

61. C. L. Jones, "Permian Basin Potash Deposits, South-western United States," in Proseedings of tile Syzosium on Saline Deposits, Hanover, 1968, Uirsco, 1970 .

62. C. V. Theis et al., "Ground-water Hudrology of Areas in the Pecos Valley, Hey Wexico," pp. 38-75 in U.S. lational Resources Planning Board, Pecos liver Joint Investigation. Reports of the Participating Agencies, hashington, D.C., U.S. Govt. Printing Office, 7.942.

63. H. W. Plerce and T. A. Gerrard, "Bveporite Deposits of the Permian Holbrook Basin, Arizona," in Second Symosium on Salt, Vol. 1, Northern Onto Geological Society, Cleveland, 1966.

64. E. A. Koester, "Srilt. Dames in Arizona," Arizona O1l and Gas Comission Geology Report bio. 1 (1971).

65. H. I. Alling and I. I. Briggs, "Strstigraphy of Upper Silurian Cayugan Evapori'ces," Bull. Am. Assoc. Petroleum Geologists 45, 515-47 (1961).

66. P. R. Giroux, "Sumary of Ground-water Conditions in Michigan," Michigan Department of Conservation, Geological Survey Division, Hater Supply Report 7 (1963).

67. W. I. Kreldler, "Occurrence of Siliurian Salt in Rew York State," Iew York State Musem Bull. 361, 1-56 (1957).

58. H. E. Reed, "Salt Deposits of the Hilliston Basin--United States Portion," Sympesium an Salt, Northern Chio Geological Society, Cleveland, 1961.

69. F. Gera and D. G. Tacobs, Considerations in the Long-Term Management of High-Ievel Radiciactive hastes, CRill-4762 (I972).

70. G. Dickinson, "Geological Aspects of Abnormal Reservolr Pressures in Gulf Cosst Iouisiana," Bull. Am. Assoc. Petrol. Geologists 37, 410-32 (1953). 
71. Bill Rehm, "Worldwide Ocsurrence of Abnormel Pressures, Part II," presented at the Tiird Symposium on Abnormal Subsurface Pore Pressures, Baton Rouge, La., May 15-16, 1972; to be published in the Proseeaings.

72. W. H. Fertl, "Worldwide Occurrence of Abnormal Forsation Pressures, Part I," presented at the Third Symposium on Abnormal Subsurface Pore Pressures, Baton Rouge, La., May 15-16, 1972; to be published in the Proceedings.

73. A. W. Musgrave and W. G. Hicks, "Outlining Shale Masses by Geoohysical :ipthods," in Dianirism and Dianirs, Memoir No. 8, Americrn Association of Petroleum Geologists, 1968, pp. 1:'2-36.

74. H. H. Ri ike III, "Mineralogy cilmontillonite under Elevated Tempex ature and Pressure," presented at the Third Symposium on Abnormal Subsurface Pore Pressure, Baton Rouge, La., May 15-16, i972; to be published in the Proceedings.

75. P. F. Kerr and J. Barringtoin, "Clays of Deep Shale Zone, Caillou Island, Louisiana," Bull. Am. Assoc. Fetrol. Geoiogists 45, 1697-1712 (1961).

76. D. D. Eberl and J. Hower, "'he Diagenetic Conversion of Smectite to Illite/Smectite: Experimental Determination of Reaction Rates" (abstract), in 1971 Annual Mectings of the Geological Society of America: Washington. D.C., November 1-3, 1971.

77. R. E. Grim, Clay Mineralogy, McGraw-Hill, New York, 1968.

78. P. F. Inw and D. M. Anderson, "The Partial Specific Volume of Water in Bentonite Suspensions," Soil Sci. Soc. im. Proc. 22, 22-24 (1958).

79. R. L. Bradshaw and W. C. McClain (Eds. ), Project Salt Vault: A Demonstration of the Disposal of High-Activity Solidified Hastes in Underground Salt Mines, ORNL-4555 (Aqril i9n).

80. T. F. Lomenick, Accelerated Deformation of Rock Salt at Elevated Temperatures and Pressure, CRNL-TM-2102 (Mexch 1968). 


\section{OPERATICNAL SAFETY}

\subsection{Isotope Migration}

A. P. Malinauskas

The significance of isotope migration must be considered with reference to two different time scales. Over the stort term, the primary concern is one of safety to personnel while the waste repository is operational; consequently, we have investigated the possibility that rapid transport mechanisms, including hydrogen explosions, could endanger these individuals. In contrast, very slow transport processes, while unimportant over tire intervals comparable to the reposicory operational period, can, in principle, corpranise the concept of the salt impenetrability when viewed in terms of the period during wich the waste material must be isolated from the biological environment. Furihermore, these slower mechanisms will protably determine the extent of overcoring required in the event that retrieval of the radioactive waste becomes necessary. Therefore, studies of the slower migration mechanisus have also been continued.

During this report period, the investigations regarding effects wich are important over the briefer time span were, in effect, confined almost strictly to considerations of the likelihood of hydrogen concentrating in burial boles or rooms in sufficient quantities tinat explosions become a possibility; the particular studies made were concerned with the behaiior cf crushed salt colums in the uresence of vater yapor and, wore directly, with bydrogen flamability in crusined salt.

The isotope migration mechanism: of potential significance, when riewed over the longer time spans wich have been studied, have irvolved only surface diffusion. In adaition, however, the experimental search for possible synergistic effects, as well as atterpts to estjmate the importance of aerosol transport, have been continued; these stuilies consist of "integrated" experiments, in wich the transport of tagged species (in simulated waste) through crished salt columis is being investigated. 
3.1.1 Transport of Water Vapor Through Crushed Solt Beris Under Woni sothermal Conditions (R. B. Jvans III, ?. L. Rutherford)

Considerable attention has been given to measurements of the rates of migration of zases through crushed salt since this maierial will serve as backfili in salt-mine repositories. ${ }^{l}$ Interest in water vapor transport, in particular, is generated as the result of several effects which are initiated when heat-generating wart.e containers are buried in beaded salt and then backfilled. The bedaed salt contains brine-filled cavities. When the tempe:atures of the region surrounding the buried conteiners rise, thermal decrepitation and fracturing of the salt occur, and the brine-filled cavities migrate up the thermal gradients to the hot ourfaces about the waste containers. As a result, brine is released nesr the containers.

Water vapor fron the released brine, if not decomposed by the waste container, will then move upward in the crushed salt backill torard lowtemperature zones, where condensation can once again occur. is time progresses, the thermal gradient will extend to all points in the backfill, so that the condensrition point can possibly wove sprard in the backfill until the process is terminated as a result of salt reconsoliantion.

Moreover, the plausibility of the occurrence of these events bus already been established. Decrepitation fractures were described by Bradshaw, Bupson, and Boegly; ${ }^{2}$ indications of free brine near burled heaters were reported by Kegloy and Bupson; ${ }^{3}$ measurements of vater vapor production in burial holes were reported by Bredshav and Mclain; ${ }^{4}$ and observations of considerable reconsolijation of backfill adjacent to simulated waste containers were likewlse noted. 5 Hence the objective of the present imrestigation ras to study the effects of weter vapor transport through crushed salt beds under nonisothernal conditions, with particular attentior. being given to molsture-induced salt reconsolidation. Furthermore, for reasons of expedience, the studies were conducted in the absence of compaction effects (nole closure) resulting from plastis fow of the salt in the formation. 
The first two experiments were performed with time--constant temerature profiles maintained along the lengths of the crushed salt colums; these experiments were indertaken to test the experimental approach as well as to observe consoliciation effects under restricted conditicns. Some of the data obtained have aiready been reported. 6 In this section, we have summarized the results of these two experiments and then described anotber, dynamic experiment in wich the crushed salt colum temperatures were systematicaliy varied, both with respect to position and tine. Figure 3.1 is a schematic jrawing of the apparatus with itich all of the experiments were performed.

All of the beds were prepared by packing fine-grnie salt (average grain diaceter, $\sim 0.8 \mathrm{~mm}$ ) in 1-in.-ID Pyrex pipes. However, before the salt was packed, a 5-ran-OE Fyrex thermocouple weli (item A in Fig; 3.1) was inserted and anchored in a perweable salt ccre (B), which bad been secured in the pipe. This core also served to support the crushed salt bed (C).

A high-temperature zone was mintuined about the core-bed interface by a beater (D), anj satisfactory temperature profiles were developed and maintained by insulating the bed with a sut table naterial (E). Periodic observations of tine bea were wide through windows in the insulation; these windows were covered when not in use.

The wate: level in the heated beaker (see Flg. ?.1) was contiviled by the position of the tube ' $F$ '), which led from the reservoir (F). Gas Now through the bed originated from the gas line (GG') and exited through an efflvent line contained witlin the rubber stopper (H). The legres of water-level depression within the pipe containing the salt bed yielded pressure-drop values for How deterninations, whereas the temperature prifile data were obtained from thermocouple surveys that were ande alons the length of the thernocouple wil?.

Besause the Pyrex pipe ma not insulated above the mater level in the beaker, a condensate ring wa obsersed inside the tube about $1 \mathrm{~cm}$ above the vater level. The temperature at the location of the ring ans deternined to be only $5^{\circ} \mathrm{C}$ less than that of the meter in the beaker. Since the terperature increased above the ring (1.e., In tive ifrcction of the insulatec'

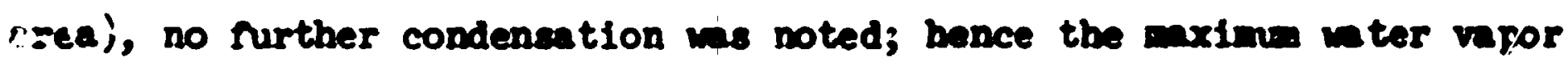




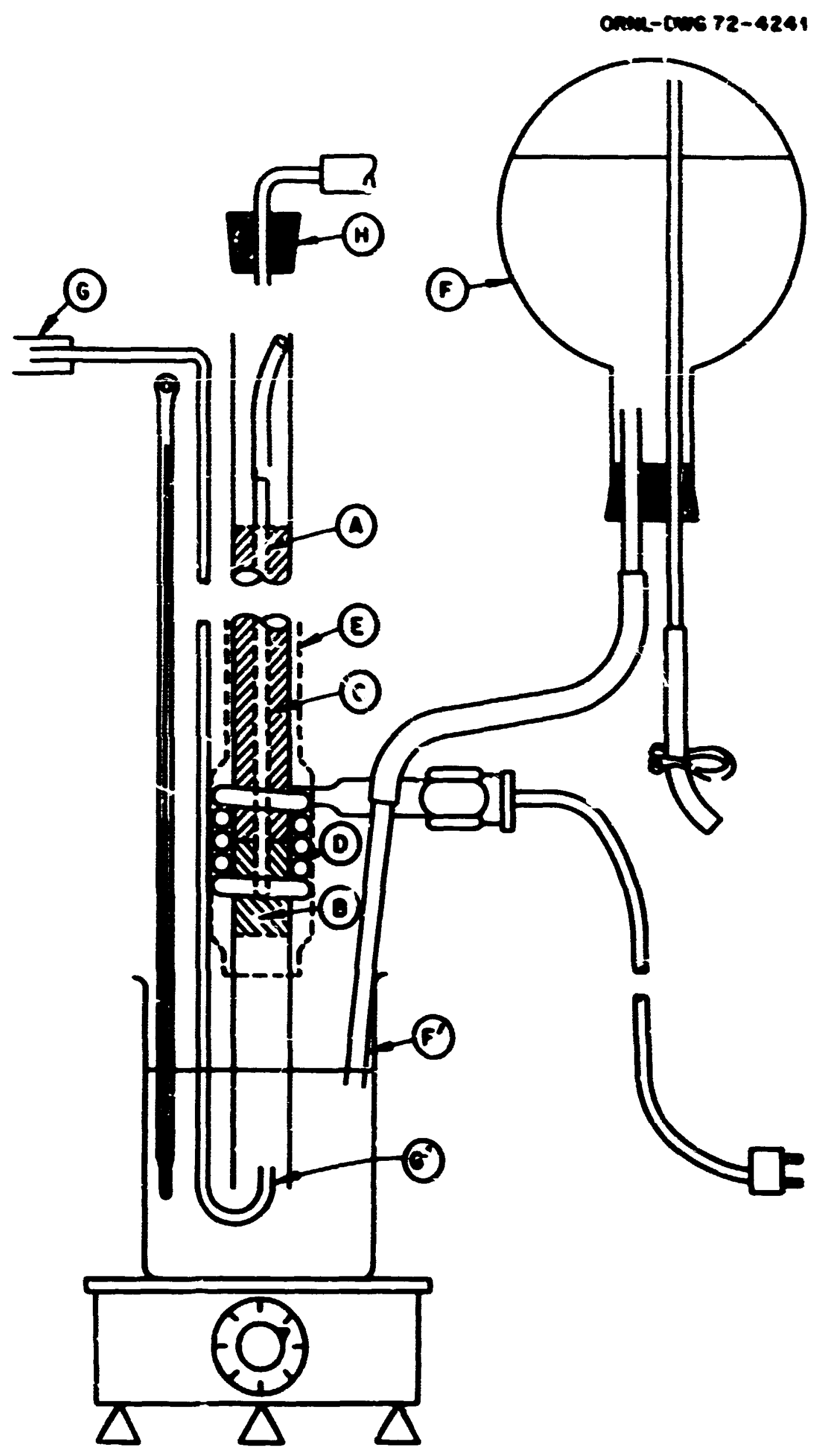

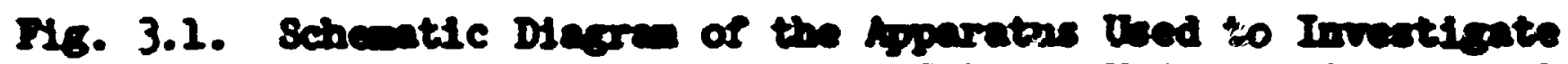

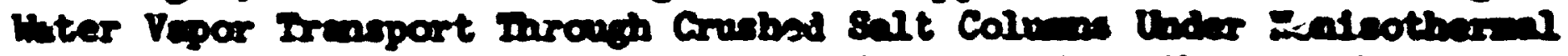

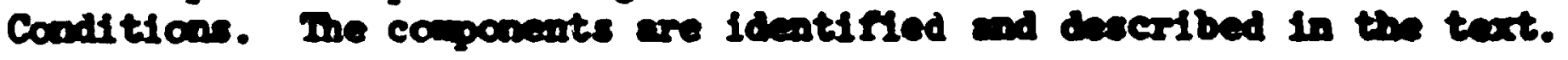


mole fraction with respect to the bed regions is given by the ratio of the vater vapor pressure at the condensate ring temperature to the total atuaspheric (i.e., baranetric) gressure.

A ary-wet interface within the crushed salt bed will occur at that polat at wich the temperature corresponds to the $d \%$ point (DP). This temperature will always be Jreater than the source ienperature because of the vapor pressure depressior due to salt that is dissolved in the 11quid. Specifically, over the temperature range of interest, the disso:.ved salt in brine on grain surfaces depresses the water vapor pressure by about 25\%; thus, if near-equilibrium conditions prevail, the vapor f-essure of water at the dew pcint will be about four-thirds that of the scurce vapor pressure. Therefore, the position at which condensation occ urs within the salt bed can be deterfied from the teperature profile of ti e bed, the source temperature, and the lenperature-pressure relationship $22 x$ stean.

Is initial experiment vas conjucted by delivering the water vap: to the crusbed salt bed by means of a contimuous flow of air through the bed. The vater vapor, which had a pressure corresponding to that at the $69^{\circ} \mathrm{C}$ conde wate ring, passed through the hot zone ( $T_{\max }$ about $270^{\circ} \mathrm{C}$ ) and then condensed at positiois within the bed at temperatures equal to or less thun $76^{\circ} \mathrm{C}$. The experiment was terminated when the ovcrall bed perneability decreased to near zero. The reason for the decrease was the formation of a consolidated bridge in the salt, whose midpoint corresponded to the $76^{\circ} \mathrm{C}$ dew point.

Pormation of the bridge required only 3.6 days; noreover, the relationship between source teperature and dew point ras verified. This agreesent sas wie, in part, to the circunstences surrounding the experinent; for exaple, gradients in steen concentration were elininated as a result of tive contimous now of alr through the bed. Furthermore, this sinplification perndtted us to estinate vater vapor transport through the bed and weter retention in the bed. These computations suggested a sall 1088 of effluent, with retentlon of $4.0 \mathrm{~g}$ of vater; the anount actually retained was found to be $4.2 \mathrm{~g}$. 
In contrast, the second experiment was conducted at constant pressure with no air sweep through the bed except wher ocsasional measurements of the permeability of the hed were being made. This experiment was terminated, again due to bridge formation, afte 14.4 days of operation. As before: the water retained by the bed amcunted to about $4 \mathrm{~g}$. Calculations which were made on the basis that concentration diffusiun was the water vapor transport mechanism indicated agreement with observations regarding the dry portion of the bed, and suggested that thermal diffusion effects could bo neglected. Furthermore, the controlling mechanisms wiere found io depend on vapor and brine effects above the dew point at the dry-wet interface in a manner too complex to be treated mathematically.

The calculated temperature profiles corresponding to various periods of time were then used to prepare, in stepwise fashion, a family of fixed profiles. Half of these profiles are graphically presented as solid lines in Fig. 3.2; the actual values obtained are shown as data points.

For this experiment, the length of the bed was increased from 12 in. to 26 in., auxiliary wrap-on heaters were employed, and a time-to-termination period of 28 days was arbitrarily adopted.

The same sequence of events recorded for the tro previous experiments was observed to occur at laast three times in this experiment. All of the moisture-related phenomena described earlier were ilgain noted, along with additional features resulting from the time variation of the temperature profil.e. For example, the water initially tended to set up consolidation patterns, as had been observed in the previous experiments, but the continued increases in temperature forced the water further up the column befcre a bridge couid be formed. As the wet region passed up the column, however, zones of var;ing degree of consolidation remained.

Each of the three experiments vividly demonstrated that the movenent of small amounts of water, in the form of vapor or brine, could produce 8 sriking changes in the physical and gas transport properties of crushed salt beds under nonisothermal conditions. Such changes occur in moist regions 28 the result of consolidation and the attendant formation of condensation-evaporation cycles. These reflux cycles effectively move 


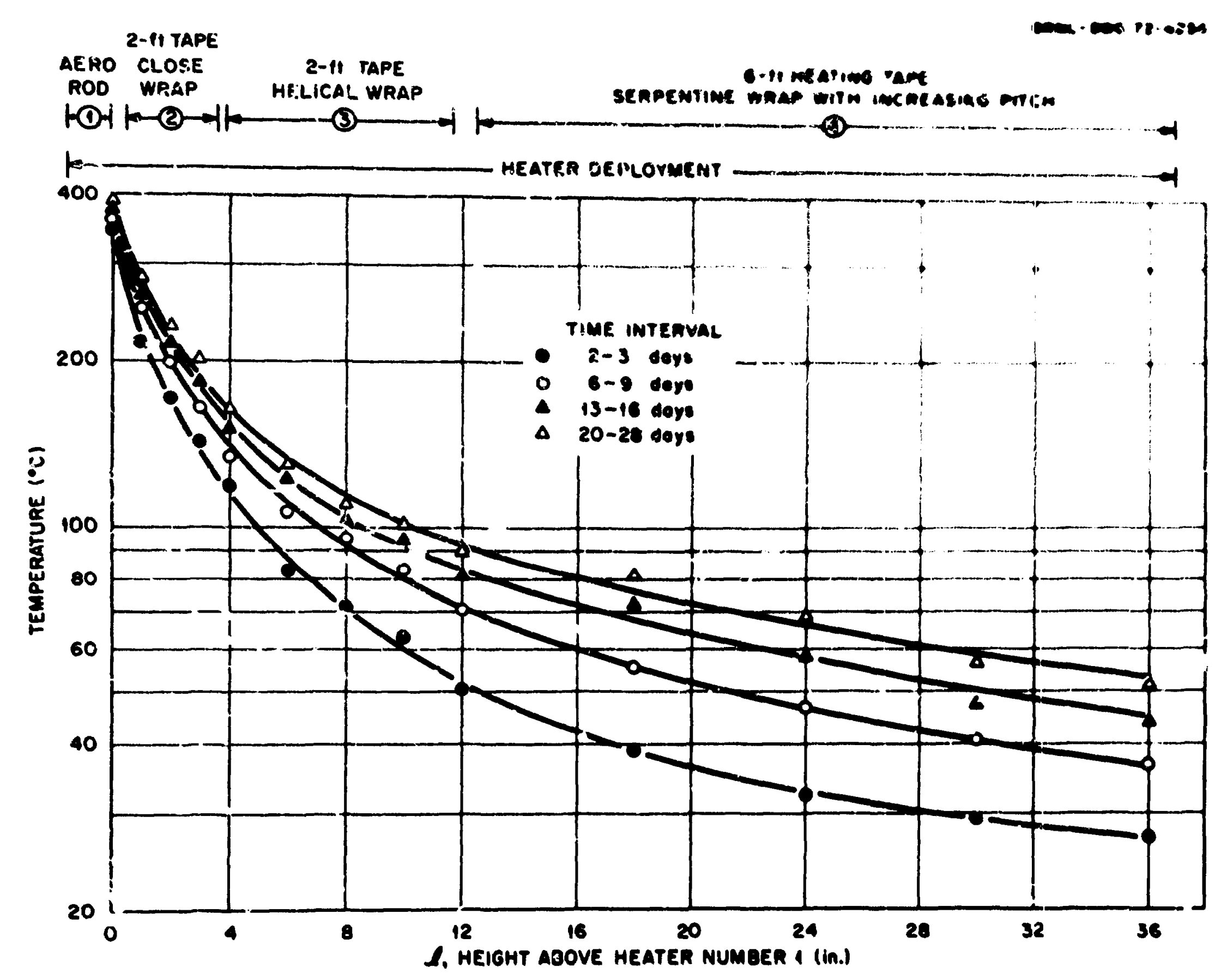

Fig. 3.2. Comparis on of Calculated Temperature Profiles Simulating Mine Conditions and Average Temperatures Which Were Maintained in the Crushed Salt Bed. Four time intervals are presented. Deployment of the heaters with respect to column locations is indicated. 
the salt from cool to hoi zones and, in the process, create voids and regions of high density. Even in moist regions, where refluding is not extensive, come consolidation occurs,

With the excertion of the mode of water injection, the ionditions and configurations of the first two experiments were aimilar. As a consequence, severel observations were comon to both. Indications of condensation appeare 1 at early stages in each experiment, and this condensation was followed by a continued accumulation of brine until a bridge formed. Also, in each case, reflux zones were established above the bridges. These zones exhibited severe erosion, since the refluxing brine roved salt into the bridge area. Actuel grain wovement ire restricted becalise of caking; thus the erosion voids were stable and the bed beight remained constant. The integrity of the bridge, orce formed, depended ropon rater content as shown by resuits of postoperational flow tests.

Exsinination of the crisued sait beds after yemval from the Pyrex pipes confirmed the in-place observations. Various degrees of consolidation were noted il the bed. Furihermore, gas flow tests which were made on sections of the consolidated cores indicated the region of lowert permeability to be that about the dry-wet interface, and appreciable permability zeduction was experiencea above the erosion zones.

The last experiment in this series was nost realistic with regard to simulation of mine conditions in that the texperature profile of the crushed salt bed was adjusted with time. Although the effects of factrrs wich control the tomperature gradients are open to yuestion, a set of timetemperature data* was prepared for our use in thermal analyses. These date were applicable in an approximate unanner to a single 5-kW waste contaje:= (6 in. OD $\times 10 \mathrm{ft}$ ) buried in a 10-in.-ID by 18-ft-deep bole. At time zero, adjacent conteiners ( $15 \mathrm{ft}$ away) and backfill were assumed to be prosent. A complete description of the model employed in the caierlations is gi ren alsewhere. 7,8

\footnotetext{
*Data were obtained by. W. G. Murner and R. D. Cheverton.
} 
Salt in the high-temperature regions (at tamperatures of about $400^{\circ} \mathrm{C}$ ), wich sinulated the top of the waste container, was not al tered appreciably; it either remined d-y or was molst only for a brief period of time. Metal components in this region indicated no corrosion effects; thus it is clear that high-pomer-density containers bave some merit because brine camnot exist in these regions at atwospheric pressure, and the absence of brine aitigates $x$ tal corrosion.

It is not clear whether woivture--induced consolidation in the crushed salt backfill will produce a plug witith will sustain high gai pressures. Our results suggest that the formation of a plug camnot occur during early time spans. However, effects of hole slosure due to plastic flow of the bedded salt have not been considered; in addition, our water vapor source concentrations may not be realistic. The nets for additional, full-scale, in-situ tests is, therefore, indicated. Further, since plug formition remins as a likely long-term possibility, scme gas perneability studies of bedded salt per se have been instiated.

\subsubsection{Hydrogen Flamability Studies (R. A. Lorenz)}

Corrosion of a 5-ky radicuctive waste container wouid result in the release of about 400 moles of hydrogen per year if all of the water associated inth brine inflow were converted by a corrosion mechanism into hydrogen and oxidized metal. 9 on this bas:s, it is apparently possible to attain hydrogen concentrations in air in excess of $4 \mathrm{vol} \%$, the explosive linit mormally quoted. Consequently, we have undertaken a search of the literature to determine the extent to which the small pore size and the large surface surea of crusked salt backfill will affect the 1gaition and flame propagation characteristics of hylrogen-air mixtures.

Virtually no infciretion concerning risme propagation in unconsolidated Dorous media exists. The most detailed work of relevance is that of Holm, ${ }^{10}$ who determined the flame propagation (and hence ignition) limits of hydrogej-air mixtures in smooth copper tubes and in glass tubes at a tmospheris pressure. Holm observed that tubes smaller than $0.09 \mathrm{~cm}$ in diemeter would prevent: propagation in hydrogen-air mixtures, al though the propagation in mixturee containing 33 vol \% of hydrogen were the most difficult to prevent. Thiolius about $0.15 \mathrm{~cm}$ in dismeter stopped flames 
with a $H_{2}$ content less than $20 \%$ or greater than $50 \%$, whereas tubing approximate $30.30 \mathrm{~cm}$ in diameter stopped flanes with a $\mathrm{H}_{\mathrm{z}}$ contert less than $10 \%$ or greatei than 59\%. Furthermore, for hydrogen concentrations up to 2\%, similar results were obtained using holes in coprer foil ana mica plates; these observations indicate ifttle sensitivity of material or hole length on the flame propagation characteristics.

Mary studies have been made of quenching diameter, or quenching distance (i.e., the diameter of a tube, $O$ : the distance between parallel plates, below which it is not possible to ignite a given explosive mixture). These distances can be correlated with the properties of the gas mixtures about equally well using either molecular diffusion or thermal conductivity models. Beriad and Potter ${ }^{11}$ employed this type of approach to derelop relationships between the quenching distance and various geometrical parameters, and performed experiments with propane-air mixtures to test the relationships is they apply to rectangular channels, cylindrical annuli, and tubes. However, their correlations cannot be applied directly to unconsolidated porous media, even though an estimate can be made if equivalent geometrical parameters are employed.

The permeabilities of several gradez of crushed salt to helium have been reported, 12 and calculations of the mean pore diameter, $\left\langle\mathrm{a}_{\mathrm{c}}\right\rangle$, have been obtained through the use of the capillary model relationship

$$
=\mathrm{d}_{\mathrm{c}}>=\left[32 \mathrm{~B}_{\mathrm{o}} /\left(\mathbf{c}^{\prime} / \mathrm{q}\right)\right]^{2 / 2},
$$

where $B_{O}$ is the viscous flow coefficient and $c / q$ is the porosity-tcortuosity pactor for gas transport. A sumary of these values and the characteristics of the crushed salt employsd in constructing the beds is presented in Table 3.1.

Another method for obtaining a characteristic geometrical parameter evolves from a definition of the hydraulic radius. In terms of this definition, an equivalent diameter, $a_{9}$, is obtained via the relationship 13

$$
d_{e}=4 m=4 e_{t} / s_{2} \text {, }
$$


Table 3.1. Comparison of Fronerties of Crushed Salt Beds

\begin{tabular}{|c|c|c|c|c|c|c|c|c|}
\hline Grade of salt & $\begin{array}{c}\text { Size Range, } \\
\text { Max./Min. } \\
\text { (cm) } \\
\end{array}$ & $\begin{array}{c}\text { Viscous Flow } \\
\text { Coesficient, } \\
\mathrm{B}_{0} \\
\left(10^{-9} \mathrm{~cm}\right)\end{array}$ & $\begin{array}{c}\text { Porosity- } \\
\text { Tort_dity } \\
\text { Rat1o, } \\
\text { ' } / 9\end{array}$ & $\begin{array}{c}\text { Total } \\
\text { Poros } 1 \text { ty, } \\
\text { et }\end{array}$ & $\begin{array}{c}\text { Surface Area } \\
\text { per Unit Bod } \\
\text { Voiume, } \\
\text { Bi }_{\mathrm{B}} \\
\left(\mathrm{cm}^{2} / \mathrm{cm}^{2}\right)\end{array}$ & $\begin{array}{l}\text { Mean } \\
\text { Pore } \\
\text { Diem., } \\
\text { ed } c^{2} \\
(\mathrm{~cm})\end{array}$ & $\begin{array}{c}\text { Equivalent } \\
\text { Pore Dian., } \\
\mathrm{d}_{\mathbf{e}} \\
(\mathrm{cm})\end{array}$ & $\begin{array}{l}\text { Batimated } \\
\text { Flamability } \\
\text { Limit } \\
(\operatorname{vol} \& \mathrm{H})\end{array}$ \\
\hline Mediun & $2.95 / 0.0044$ & 244 & 0.237 & 0.375 & 15.7 & 0.057 & 0.096 & $>25,<40$ \\
\hline $\begin{array}{l}\text { 50-50 wt \& } \\
\text { Me.t.-Fine } \\
\text { Mixture }\end{array}$ & $0.95,0.1244$ & 3.28 & 0.125 & 0.268 & 64.8 & 0.0092 & 0.017 & lio ignition \\
\hline Pine & $c .34 / 0.001,4$ & 4.36 & 0.212 & 0.377 & 94.6 & 0.0081 & 0.016 & lio ignition \\
\hline $\begin{array}{l}\text { T:uncated } \\
\text { Run-of-MIII }\end{array}$ & $0.80 / c .007$ & 1.97 & 0.157 & 0.344 & 131. & 0.0063 & $0.0 ? 0$ & in ignition \\
\hline
\end{tabular}


where $m$ represents the hydrailic pore radius, $\epsilon_{t}$ is the total porosity of the septum, and $S_{B}$ denotes the partjcle surface area per unit bed volume. Values of de for each of the four beds of crushed salt are also given in Table 3.1, and it is obvious that this paremeter is consistently larger than the mean pore dirmeter, $\left\langle d_{c}\right\rangle$, calculated from the gas transport experiments. We, therefore, employed the equivalent diameters, $d_{e}$, and the data obcained by Holms using smooth tubes to estimate flamability limits for the various crished salt beds (see Table 3.1). Since no tests of our method have been maje, experimental verification of these resuits would be required if it became necessary to establish the fiamability limits more precisely. In addition, with some grades of crushed salt, the fines would have to be excluded from the surface area calculation because of their tendency to segregate. The effects of water vapor and total pressure on the flammability limits ipe been investigated; ${ }^{14}$ over the range studied, the effects are small and may be neglected.

The quenching effects considered thus far involire distances between surfaces. However, an additional flame-quenching mert.snisms appears to be associated with the exposed surface area. For example. Dolan and Dempster 15 studied tive quenching effect of fine suspended powcers of various materials on methane-air flames. They observed that, with $\mathrm{NaCl}$ particles 4.3 to 12.0 $\mu$ in diameter, quenching was achieved with a surface area of only $0.57 \mathrm{~cm}^{2}$ of salt surface per cubic centimeter of air. This is, of course, considerably less than the range of 16 to $131 \mathrm{~cm}^{2} / \mathrm{cm}^{3}$, wick is tabulated for the crushed salt beds. Thus, although we cannot provide a direct comparison between tije quenching of methane-ais flames and tisat of hydrogen-air flames, the large surface-area-tc-gas-volume ratio that is characteristic of cmushed salt beds will probably tend to enhance the flame-quenching ability of the beds.

It is not yet possible to estimate the characteristics of beds containing very coarse, as-excavated salt, whose use as backfill is desirable for reasons of practicality and economy. In beds of as-excavated salt, however, convention currents due to temperature and gas density gradients may assist ir. diluting the hydrogen to an extent which is sufficient to exclude the russibility of hydrogen explosions in partially ventilated burial rooms. 


\subsubsection{Surface Diffusion (B. K. Amis)}

Until recently, our effort to estinate the significance of surface diffusion (and, by extension, of grain-boundary diffusinn) as a mode of isotope migration has been centered on the use of $\mathrm{La}_{2} \mathrm{O}_{3}$ as an appropriate substitute for plutonium. Our results indicate that, unless wore stringent requirements are adopted, surface diffusion is unlike' $y$ to be a so:rce of safety hazards. As a further precaution, however, the exferimental work has recently been extended to include an investigation of the behavior of Sro, thich will provide a measire of the rate of transport of smailer moiecuies and, in addition, is of intrinsic interest.

The samples employed in the Los $\mathrm{O}_{3}$ surface diffusion experiments consisted of highly polished laCl coupons (originally intended for use as windows in infrared spectrometers) with the approximate dimensions $17 x$ $8 \times 2$. A portion of each coupon was covered with a $\mathrm{La}_{2} \mathrm{O}_{3}$ film, as indicated in Fig. 3.3. Although reference is made in this figure to a Las $a$ coating thickness of $633 \boldsymbol{\Lambda}$, wich was exployed in the final set of experiments (and from which most of the conclusions heve been drawn), films of about $150 \boldsymbol{h}$ and $3000 \boldsymbol{\Lambda}$ were also exanined in the course of the stualies.

Some preliminary results, in which the corcentration profile in the direction of the arrow in Fig. 3.3 were detarmined using an electron microprobe, were reported previousiyl for a sample that had been diffusionanneaied (for a few days) at $200^{\circ} \mathrm{C}$. An unexpectedly ucderate charge ot,served in $\mathrm{La}_{2} \mathrm{O}_{3}$ surface concentretion with distance from the assumed edge of the initial deposit was believed to be an artifact of the technique: employed to mask the $\mathrm{KaCl}$ during deposition of the $\mathrm{I}_{2} \mathrm{O}_{3} \mathrm{fllm}$. Subiequent work supported this hypothesis. After the situation had been cosrected, the microprobe data indicated that, if surface diffusion were occurring at a sensible rate, it must be proceeding at a level involving less than. a monolayer of molecules.

Since concentrations of this magnitude are just at the limits of detectability of electron microprobes, other methods for determining the cuncentration profiles were explored. One of these involved bcibardment of the surface with high-energy cxygen ions and obserration of the induced 


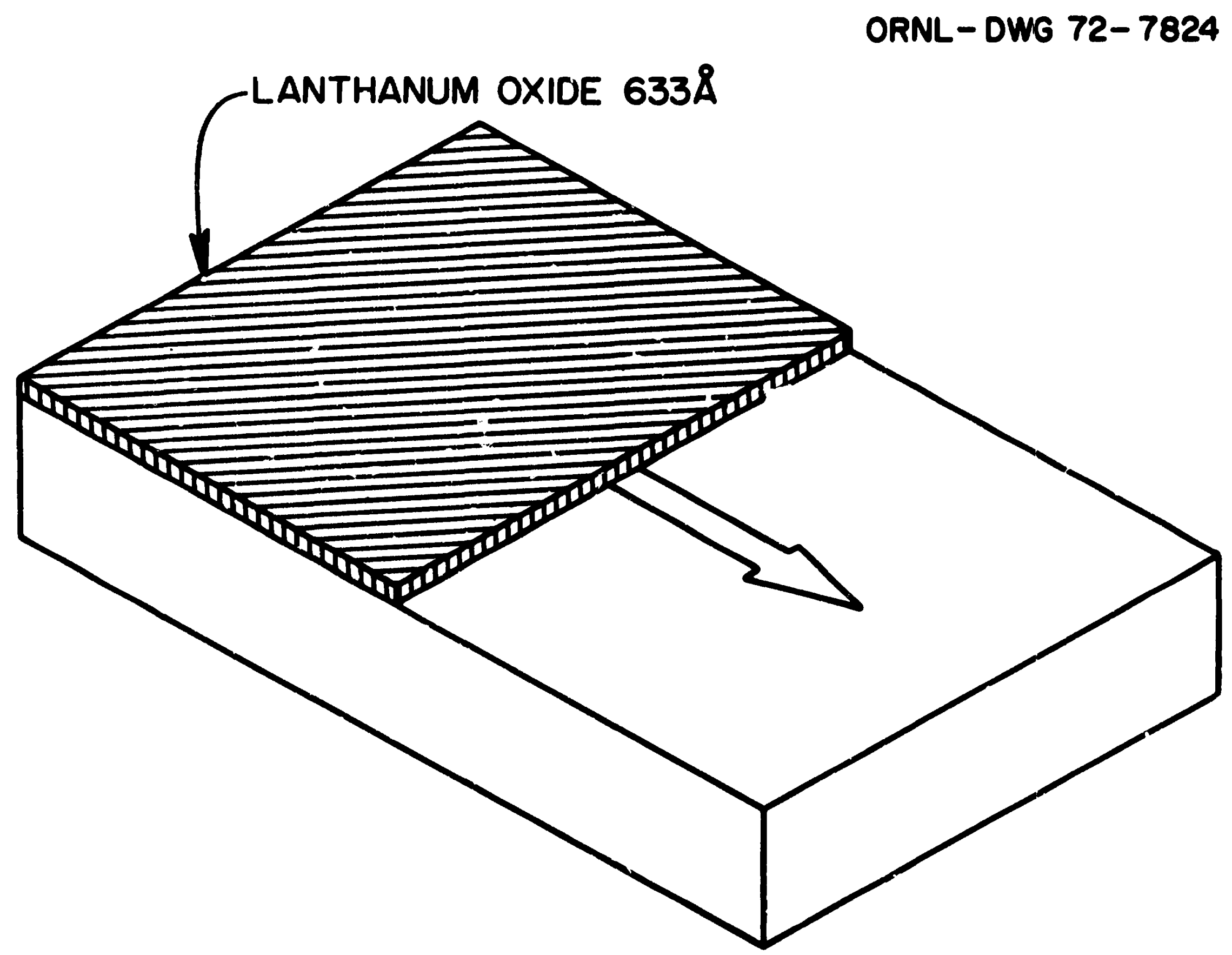

F.8. 3.3. Schumatic Representation of the HaCl Conpons Uned in the Surface Difrusion Studies. The arrow indicates the direction of the surface difrusion. 
$X$-ray fluorescence of the lanthanua. The results indicaled a somewhat higher sensitivity for this wictbod than for the nicroprote, bist ith a $108 s$ in spatial resolution. A second alternative, wish vtilized a spark-source mass spectrometric technigie, was observed w provide a higher sensitivity with respect to a determination of lunthanu concentration than the two preceding methods; however, the practical difficulties inherent in obtaining slices of the samples corresponding to

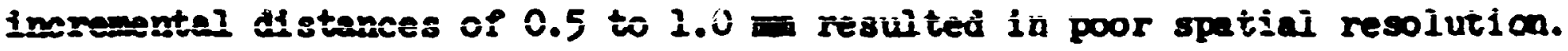

In an attempt to obtain a concentration profile of practicably measurable extent, $\mathrm{La}_{\mathrm{z}} \mathrm{O}-\mathrm{haCl}$ diffusion couple samples were anne lled at $420^{\circ} \mathrm{C}$ for pericts of $14-2 / 3$ and 36-2/3 days. Concentration analyses were then performed usiag all three techniques investigated previously. However, the performance of the electron acroprobe had impruved sufficiently in the Interim that the data were better, in a statistical sense, than date obtained by the ior-induced flucrescence technigque. For this reuson, only representative wicroprobe and mss-spectronetric results are presented in FIg. 3.4. Thise results were obtained for a sample that had been annealed for $14-2 /$ : days. In order to present the dats in the manner shown in the figure, in hich transport is assuned to occur only at silbmonolajer coverage, it was necessary to derive a value for $C_{0}$, the effective initial surface concentration. This ralue was obtained by estimating the number of molecules that would correspond to monolayer coverage. When the mass-spectrometric data, which are designated by the horizontai bars in the figure; were considered independently, $1^{4} 108$ possibj.c to est:-scte both the diffusion coefficient, $D$, and $C_{0}$. The latter renilt was in reasonable accord with the estimatid value.

The upper curve in the flgure corresponds to a hypothetical concentration profile which would result from a surface diffusion presess whose characteristic surface affision coefficient is $10^{-6} \mathrm{~cm}^{2} / \mathrm{ser}$; the lower curve is representative of $10^{-10} \mathrm{~cm}^{2} / \mathrm{sec}$. The mass-spectiometric data, wich actually yield only an upper ilmit of the megnitude of the diffusion process, oppear to correspond with the upper curve, whereas the electron microprobe data seem to favor the lower curve. Similar results were obtainea for samples that had been annealed for $36-2 / 3$ days. 


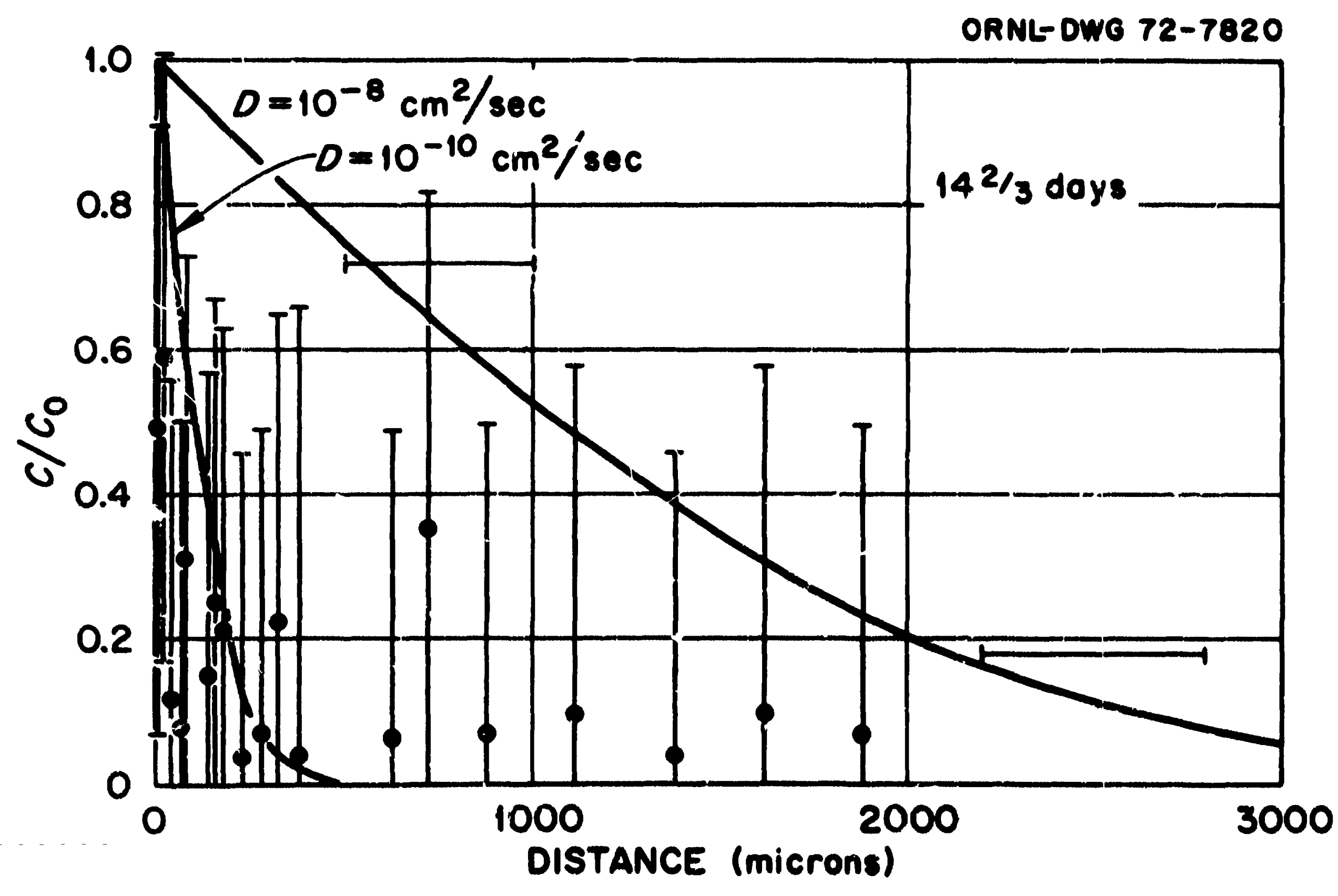

F18. 3.4. Relative Surfece Concentration Prostlo of Ia, On on MaCl After $14-2 / 3-$ Day Annew at $420^{\circ} \mathrm{C}$. The data polnte and associated vartical error bara correnpond to electron microprobe manuremente, morress the hor1zontai error burs denote the results of apark-source mase inpectromotilic determatnation. The two solid curves are theoretion profline corresponding to the difruelon coeffleiont values indicated. 
At this tine an ion probe becane available, and its potential was investigated. In this device, mterial is sputtered off the surface by a bean of variable size and then amlyzed by a mas spectrometer. The bear can be scamed over the surface in mach the sone manner as is done with the electron zicroprobe.

Data wers taken with one of the semples that had buen annealed for 36-2/3 days; these date are displayed graphicaliy in F15. 3.5. The results were obtained by sceining the beas over patches approxinately $70 \mathrm{~N}$ long (in the direction of the edge of the original is $Q_{3}$ deposit) and about So $\mu$ wide. Fifure 3.5 is actuilis a superposition of two plots, one of which shows the iogarith of the thesretical concentration as a runction of distance and ibe other shows the logaritia of the experimentally deterained concentrations as anction of distance. iransiation along the rertical axis indicates thet the data are well-fitted by a diffusun coenicient value of $3 \times 10^{-10} \mathrm{~cm}^{2} / \mathrm{sec}$ with an estimated preclation of 30 to 50\%. A few cata foints, correspoixising to distances closer than $250 \mathrm{i}$, were purposely anitted because these points seened to lie on a theoretical curve characteristic of a dffusion coefficient value of abont $10^{-11} \mathrm{~cm}^{2} / \mathrm{sec}$. While this initial behavior may be an artifuct or the deposition technique, it, is interesting to note that a siadlar behavior had been ojserved in studies of the surface diffusion of sodium in mica. 16

\subsubsection{Isotope Milgration Through Crushed SaIt (H. W. Godbee)}

A knowledge of the extent to whicb crushed salt backfill retards the transport of radioactivity is needed in order to evaluate the usefulness of salt as a barrier to tize dispersal if radioentivity in a salt-mine repository. Therefore, a series of experiments designed to represent the situation in wich high.level wate solids are exposed to crushed sult backfil 2 is in progress. Simulated waste solids irggea with e.ppropriate radioactive tracers, fission products and actinides, are used in thase experiments.

Fission Product Migration in Crushed Salt. - In the studies of wastes containing figsion products, two 4-ir..-ID by 40;-in.-high Incinel columns, eacin positioned within a furnase (Fig. 3.6) are used to hold the crushed 


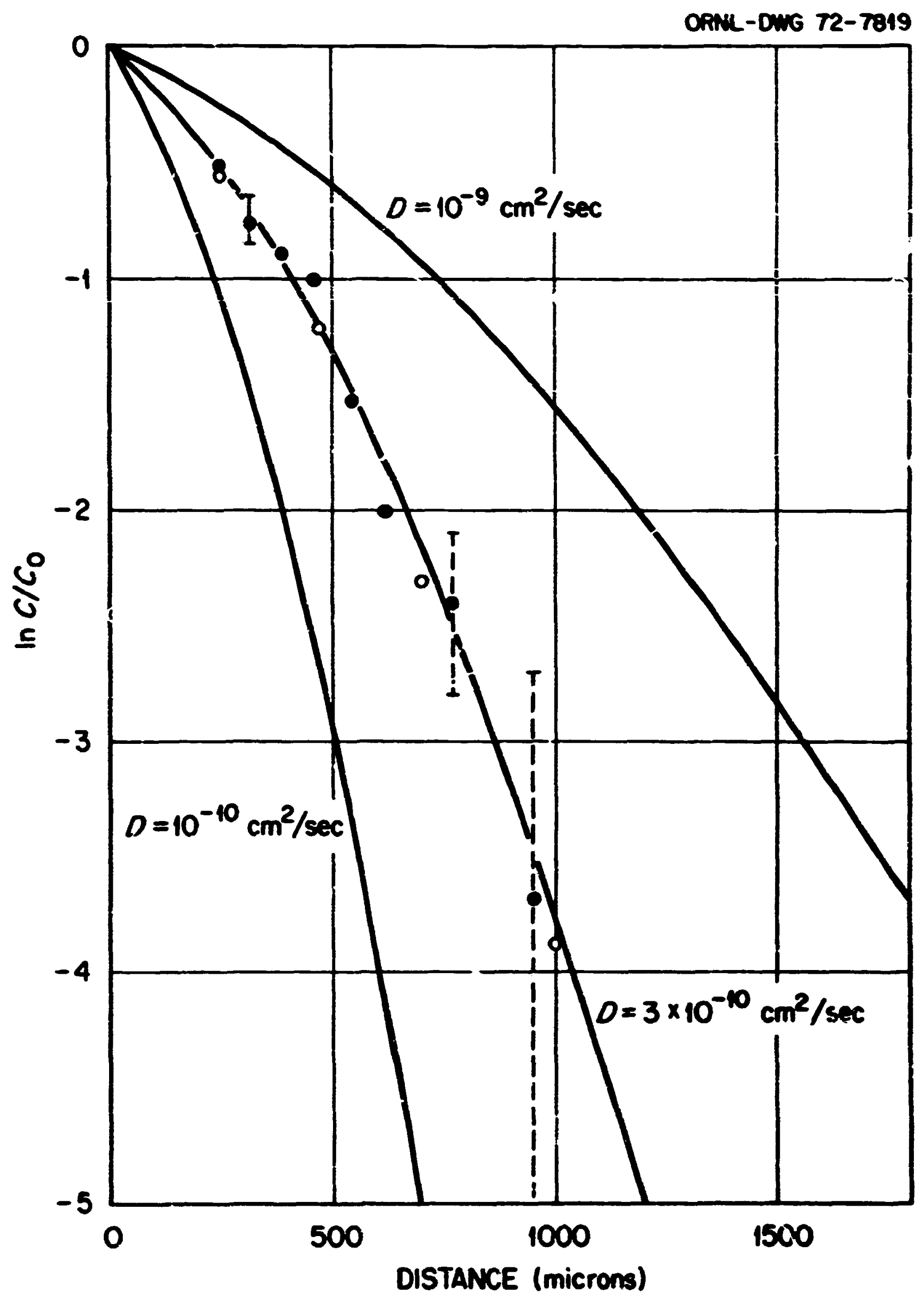

Fig. 3.5. Surface Concentration of $\mathrm{La}_{2} \mathrm{O}_{3}$ on NaCl After a $36-2 / 3-\mathrm{Dar}$ Anneal at $420^{\circ} \mathrm{C}$. The data points represent resul.ts obtaired utilizing an ion probe technique, whereas the solid lines are theoreticel resu:ts corresponding to the surface diffusion sefeficients indicaled. 


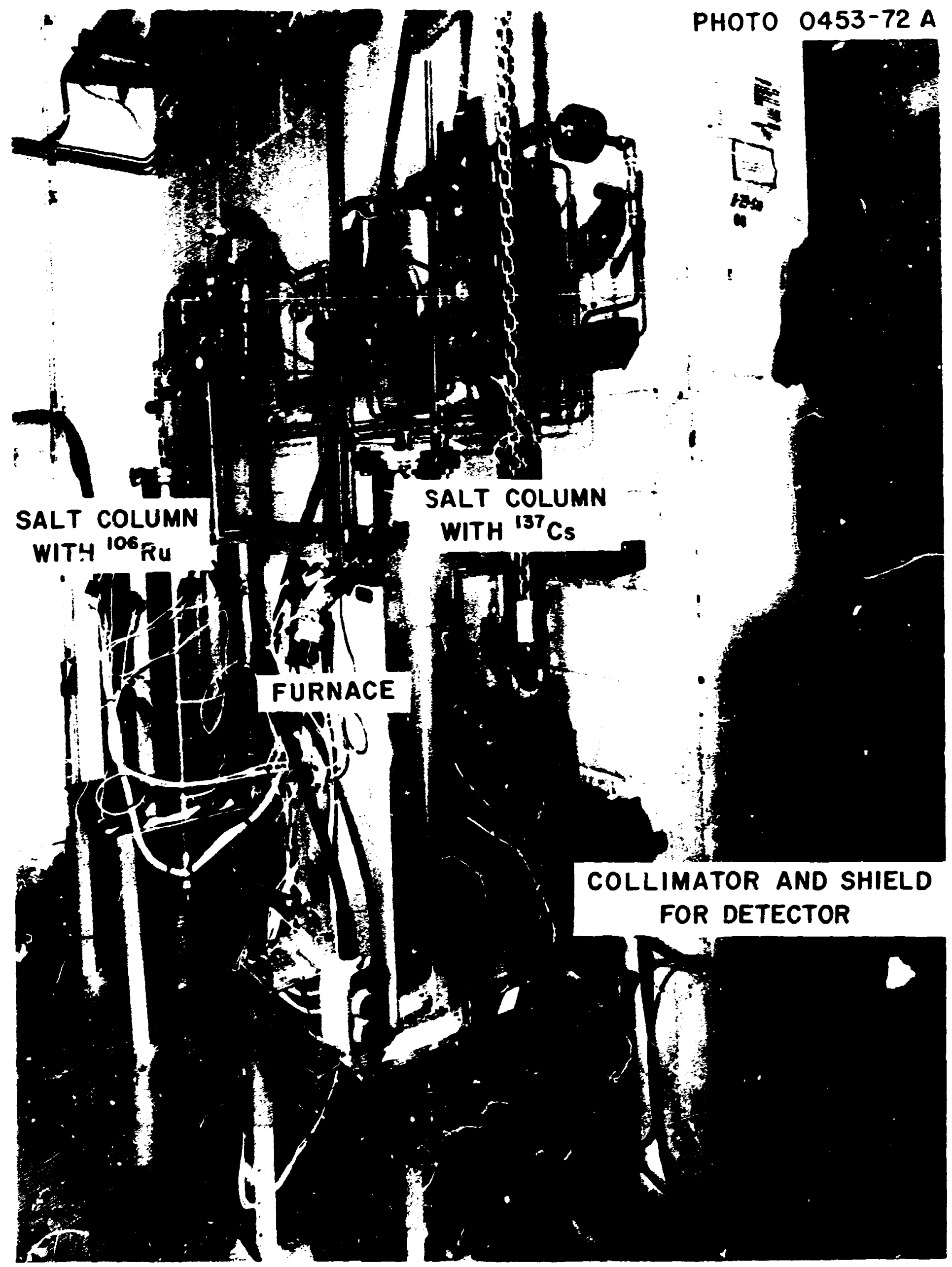

Fig. 3.6. Photograph of Apparatus for Studying Movement of Fission Products in Salt. 
salt and simulated waste tafosi with sppropriate radioactive tracers. A schematic diagram of this apparatus was presented previously. ${ }^{17}$ In the initial experiments, calciucd waste containing ${ }^{137} \mathrm{Cs}$ in one setup and ${ }^{106} \mathrm{Ru}$ in the other was placed at about the midplane of a column of crushe 3 salt, and the column was then positioned within its furnace. Each column contains $12 \mathrm{~kg}$ of crushed salt and $68 \mathrm{~g}$ of calcined waste tagged with 1 $\mathrm{mCi}$ of ${ }^{137} \mathrm{Cs}$ or $0.4 \mathrm{mCi}$ of ${ }^{i c 6} \mathrm{Ru}$ tracer. About $40 \mathrm{mi}$ of air per minute is passea through the columns, which are heid at $340^{\circ} \mathrm{C}$. The transport of waste products up or down the column is monitored by gamma scanning the column for cesium and ruthenium with a detector crystal encased in a lead collimator and shield (Fig. 3.6).

Typical gamma scans along the columns contairing ${ }^{137} \mathrm{Cs}$ and ${ }^{106} \mathrm{Ru}$ at $25^{\circ} \mathrm{C}$ and at $340^{\circ} \mathrm{C}$ are shown in Fig. 3.7. The shif 1 in the peak of these curves as the result of the increase in temperature from 25 to $340^{\circ} \mathrm{C}$ was about 0.2 in. This movement corresponds ciosely to that expected (the columns are unrestrained in their upward movement) from the thermal expansion of the salt below the radioactive source if the coefficient $0:$ linear expansion of salt is about, $4 \times 10^{-5}$ in. in..$^{-1}{ }^{\circ} \mathrm{C}^{-1}$. The count rate as a function of distance along each salt column has been fitted to an equation of the furm:

$$
C=C_{m} \exp \left\{-1 / 2\left[\left(X-x_{m}\right) / \sigma\right]^{2}\right\}
$$

w?tere?

$$
\begin{aligned}
C & =\text { counts per minute on the sama scintillation counter, } \\
C_{\mathrm{m}} & =\text { maximum counts per minute, } \\
\mathrm{X} & =\text { distance along the salt column, } \\
\mathrm{X}_{\mathrm{m}} & =\text { position of maximum counts per minute, and } \\
\sigma & =\text { standard deviation. }
\end{aligned}
$$

Tables 3.2 and 3.3 show some $c$ : the results obtoined for the salt column containing ${ }^{137} \mathrm{Cs}$ and ${ }^{108} \mathrm{Ru}$, respectively, using this fit. Among the conclusions that may be drawn from the resul's shown in these tables are: (1) the material balance for cesium and ruthenium, as represenied by the area under the profile, is closed on each successive scan; and 
ORNL DWE 72-8800R2

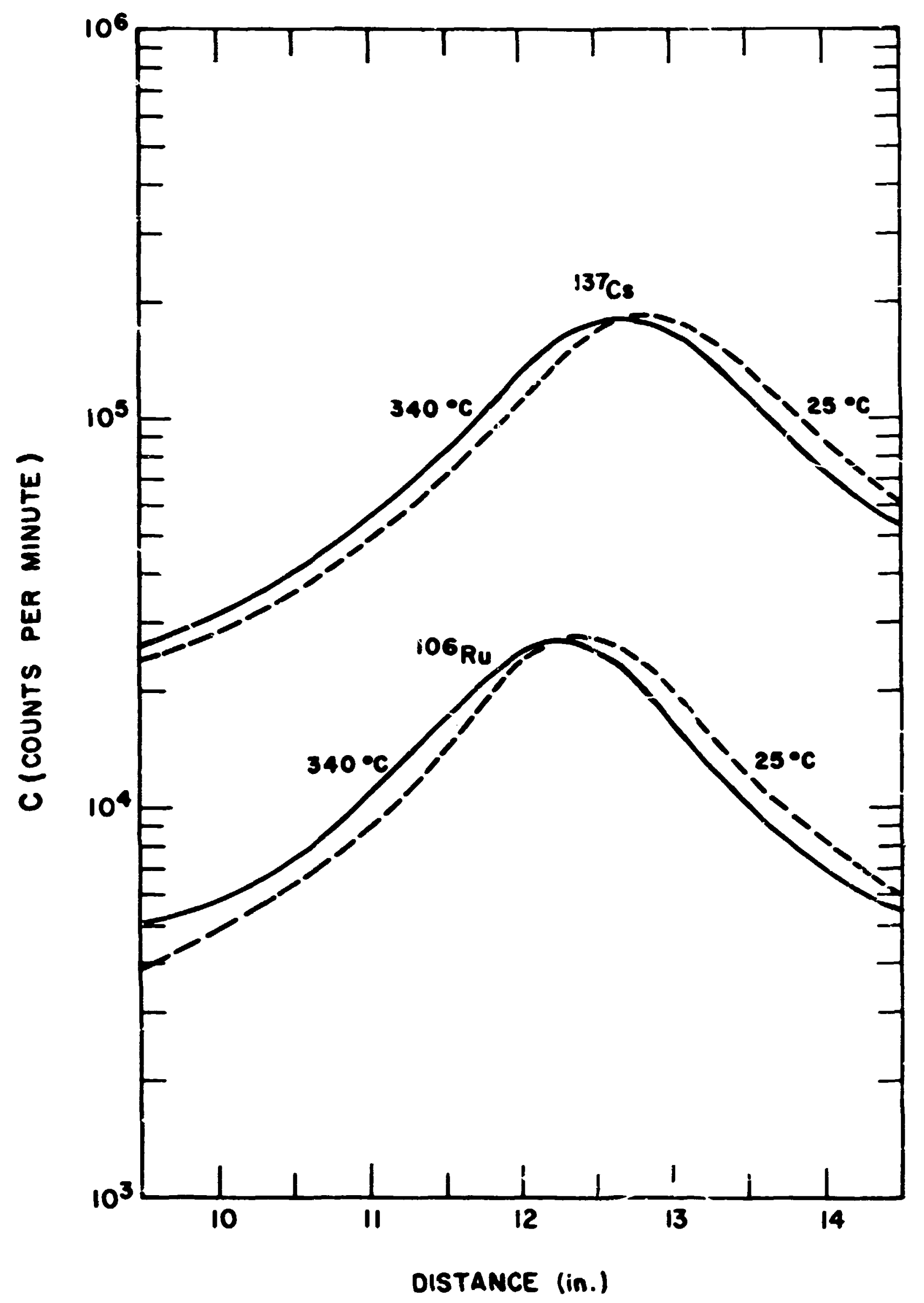

Fig. 3.7. Comparison of Counts per Minute vs Distances for Columns of Crushed Salt Containing Calcined Waste with ${ }^{137} \mathrm{Cs}$ and ${ }^{106} \mathrm{Ru}$ Tracers at $25^{\circ} \mathrm{C}$ and $340^{\circ} \mathrm{C}$. Distances are measured downwair from the top of the furnace. 
Table 3.2. Results of the Fit to a Gausian Curve of the Data Obtained by Cramma Scanning of a Selt Column ${ }^{a}$ Containing Soild Waste with ${ }^{137} \mathrm{Cs}$ Tracer

\begin{tabular}{|c|c|c|c|c|c|}
\hline Frofile No." & $\begin{array}{c}\text { Elapsed Time } \\
\text { (days) }\end{array}$ & $\begin{array}{c}\text { (3) } \\
C_{m}{ }^{c} \\
\text { Peak Height } \\
\text { (counts } / \mathrm{min}) \geqslant 10^{-5}\end{array}$ & $\begin{array}{c}(4) \\
\text { W, } \\
\text { Band Width } \\
\text { at Half-Helght } \\
\text { (in.) }\end{array}$ & $\begin{array}{c}\text { A, } € \\
\text { Area Under Profile } \\
\text { (counts min }{ }^{-1} \text { in.) } \times 10^{-5} \\
\end{array}$ & $\begin{array}{l}\text { (0) } \\
\sigma, \\
\text { Standard } \\
\text { Deviation } \\
\text { (in.) } \\
\end{array}$ \\
\hline 1 & 0 & 1.7477 & 2.400 & 4.4466 & 1.019 \\
\hline 2 & 4 & 1.7465 & 2.400 & 4.4433 & 1.019 \\
\hline 3 & 29 & 1.7416 & 2.413 & 4.45545 & $1.025^{f}$ \\
\hline 4 & 36 & 1.7436 & 2.407 & 4.4494 & 1.022 \\
\hline 5 & 57 & 1.7422 & 2.414 & $+.45,83$ & 1.025 \\
\hline 6 & 78 & 1.7443 & 2.406 & 4.4481 & 1.022 \\
\hline$?$ & 101 & 1.7433 & 2.408 & 4.4500 & 1.023 \\
\hline 8 & 134 & 1.7460 & 2.406 & 4.4527 & 1.022 \\
\hline 9 & 141 & 1.7398 & 2.411 & 4.4466 & 1.021 \\
\hline 10 & 169 & 1.7467 & 2.408 & $4.45,92$ & 1.023 \\
\hline
\end{tabular}

${ }^{a}$ Column is $4 \mathrm{in.}$ in diameter by $40 \mathrm{in.} \mathrm{Iong} \mathrm{and} \mathrm{contains} 12 \mathrm{~kg}$ of crushed salt and $68 \mathrm{~g}$ of calcjned waste.

${ }^{b}$ Profile 1 was obtained at $25^{\circ} \mathrm{C}$ with no air flow; profile 2 at $25^{\circ} \mathrm{C}$ with an air flow of $40 \mathrm{ml} / \mathrm{min}$; profiles $3-10$ at $340^{\circ} \mathrm{C}$ with an air flow $n$ f $40 \mathrm{ml} / \mathrm{min}$.

Cobtained by fitting measured counts per minute, $C$, at various distances, $X$, Elong the salt column to an equation of the form $C=C_{m}\left\{\exp -1 / 2\left[\left(x-x_{m}\right) / \sigma\right]^{2}\right\}$, where $x_{m}$ is the location of $C_{m}$.

$d_{W}=2.3548 \sigma$.

${ }^{e} \mathrm{~A}=1.06 \mathrm{C}_{\mathrm{m}} \mathrm{W}$ and represents the $1 \mathrm{mCl}$ of ${ }^{137} \mathrm{Cs}$ criginally placed in the wastie.

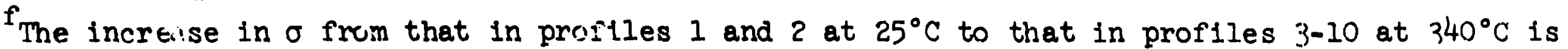
undoubtedly caused by thermal expansion of the calcire and not by diffusion. 
Table 3.3. Results of the Fit to a Gaussian Curve of the Data Obtained by Gamma Scanning of a Salt Columna Containing Soild Waste with ${ }^{108}$ Ru Tracer

\begin{tabular}{|c|c|c|c|c|c|}
\hline Profile No. & $\begin{array}{c}\text { E] apsed Time } \\
\text { (days) }\end{array}$ & $\begin{array}{c}(3) \\
\mathrm{C}_{\mathrm{m}},{ }^{\mathrm{c}} \\
\text { Peak He1ght } \\
\text { (count.3/min) } \times 10^{-4}\end{array}$ & $\begin{array}{c}\text { (4) } \\
\text { W, } \\
\text { Band Width } \\
\text { at Half-Height } \\
\text { (in.) }\end{array}$ & $\begin{array}{c}\text { (5) } \\
\text { A, }{ }^{e} \\
\text { Area Under Frofile } \\
\text { (counts min"1 in.) } \times 10^{-4}\end{array}$ & $\begin{array}{c}\text { (б) } \\
\sigma, \\
\text { Standard } \\
\text { Deviation } \\
\text { (in.) } \\
\end{array}$ \\
\hline 1 & 0 & 2.5696 & $2.25 \%$ & 6.1363 & 0.9567 \\
\hline 2 & 7 & 2.5694 & 2.254 & 6.1378 & 0.9570 \\
\hline 3 & 29 & 3.4948 & 2.294 & 6.06777 & $0.9744 f$ \\
\hline 4 & 36 & 2.4951 & 2.309 & 6.10830 & 0.9807 \\
\hline 5 & 57 & 2.5081 & 2.321 & 6.1705 & 0.9856 \\
\hline 6 & 65 & 2.5026 & 2.310 & 5.1290 & 0.9812 \\
\hline 7 & 101 & 2.4981 & 2.308 & 6.1123 & 0.3802 \\
\hline 8 & 112 & 2.4988 & 2.324 & 6.1553 & 0.9868 \\
\hline 9 & 135 & 2.5022 & 2.327 & 6.176 & 0.9881 \\
\hline 10 & 167 & 2.5102 & 2.323 & 6.1806 & 0.986 .4 \\
\hline
\end{tabular}

Eolumn is $4 \mathrm{in}$. in diameter by $40 \mathrm{in}$. long and contains $12 \mathrm{~kg}$ of crushed salt and 68 g or calcined waste.

${ }^{b}$ Prcfile 1 was obteined at $25^{\circ} \mathrm{C}$ with no air flow; profile 2. at $25^{\circ} \mathrm{C}$ with an af.r flow of $40 \mathrm{ml} / \mathrm{min}$; profiles $3-30$ at $340^{\circ} \mathrm{C}$ with an air flow of $40 \mathrm{ml} / \mathrm{min}$.

cobtained by fitting measured counts per minute, $C$, at various distances, $X$, along the salt column to an equation of the form $C=C_{m}\left\{\exp -1 / 2\left[\left(x-x_{m}\right) / \sigma\right]^{2}\right\}$, where $x_{m}$ is the location of $C_{m}$. All counts were correctec to zero time, assuming the half-ilfe of 106 in to be 368 days.

$d_{W}=2.3548 \sigma$.

$e_{A}=1.06 \mathrm{C}_{\mathrm{m}} \mathrm{W}$ and represents the $0.4 \mathrm{mCl}$ of ${ }^{108} \mathrm{Ru}$ originally placed in the waste.

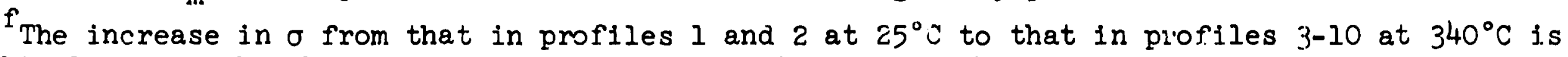
undoubtedly caused by thermal expansion if the calcine and not by diffusion. 
(2) the diffusion coefficient for cesium and ruthenium under these corditions is zero, as indicated by the faci that the standard deviation of the counting profile for each isotope is not chancing significantly with time. A completed material balance for each isotope on successive scans shows that no radial movement has occurred, since such movement would decrease the response of the detector and indicate that less cesium or ruthenium is present in the salt coiumn. A completed materiai balance plus no change in standard deviation, or any other measure of band width, indicates that no longitudinal movement has taken place, since the se two conditions can prevail oniy if tre isotopes have retained their original place in the column. Application of Student's t-distribution to the eight standard deviations for sesium at $340^{\circ} \mathrm{C}$ (Table 3.2 , column 6, profiles 3-10) shows that there is a 95\% expectation that the true average standard deviation is between $1.022 \mathrm{in}$. and $1.024 \mathrm{in}$. Similar trearment of the eight standard deviations for ruthenium at $340^{\circ} \mathrm{C}$ (Table 3.3, column 6, profiles 3-10) shows there is a 95\% expectation that the true average standard deviation is between 0.9791 in. and 0.0068 in.

Flans are to continue these studies with ${ }^{137} \mathrm{Cs}$ and ${ }^{108} \mathrm{Ru}$ and to exterd them to saj.t culumns containing raste tagged wi.th ${ }^{85} \mathrm{Sr}$ and ${ }^{144} \mathrm{Ce}$.

Actinide Migration in Crushed Salt. - In the studies of wastes containing actinide elements, the experimental apparatus is identical in concept with that for the fission products but consists of four 2-in.ID by ll-in.-high plastic columns in a glove box. The cclumrs were made by stacking plates for purposes of later sectioning the column, at 1/2-in. intervals, for analysis of actinides. A photograph of the assembled columns in the glove box was shown preiriously. ${ }^{18}$ Each of the four columns, was loaded with abcut $700 \mathrm{~g}$ of srushed salt and $6 \mathrm{~g}$ of plutonium (88.87\% ${ }^{239} \mathrm{Pu}, 9.73 \%{ }^{240} \mathrm{Pu}, 1.252 \% 241 \mathrm{Pu}$, and $\left.0.140 \% 242 \mathrm{Pu}\right)$. The plutonium, as the nitrate, was loaded into the midsection of each column. Air was pass $2 d$ upward through the four columns at rates of $0,10,20$, and 40 $\mathrm{ml} / \mathrm{min}$, respectively. The initial tests with these plastic columns were carried out at ambient temperatures. The movement of piutonium was monitored, at approximately l-month intervals, by scarning each column above and below the plutonium-bearing section with a Geiger-Miller (G-M) survey meter. 
No rovement of plutonium was detected after 6 months as determined by scans of the cclumns with the G-M meter. The columns are now being dismaniled, and twenty $32-\mathrm{g}$ sampics of salt from each of them will be analyzed for plutonium to provide an independent check on the results obtained in the rough survey.

Metai columns are being fabricated so that tile experiments can be continued at about $300^{\circ} \mathrm{C}$, using calcined piutonium dioxide to similate high-level waste exposed to crushed salt. Our plans inciude the use of a more accurate monitoring technique such as that employed in the fission product movement studies. 


\subsection{Radiation Effects}

3.2.1 Energy Storage in Solidified Wastes (G. H. Jenks, C. D. Bopp)

The high-level solidified wastes in a repository will be exposed to a variety of nuclear radiations, including thcse produced by the alpha disintegration of transuranic elements. It is possible that some of the radiation energy will be stwred in the waste solids ar lattice damage; hence knowledge of the amounts and of the thermal annealing behavior is desired primarily for use in evaluation of hazards.

We analyzed ${ }^{19}$ experimental and theoretical data on radiation damage and energy storage in oxides and silicates and concluded that any energy storage in typical caicined waste oxides and glassy solids will result predominantly frum displacements or "spikes" caused by elastic collisions of the heavy recoiling nuclei which are formed in the alpha disintegration of the transuranic elements within the wastes. Alpha radiation and, to a lesse: extent, beta radiation will also cause some damage via elastic collisions. Energy storage in the radioactive wastes will probably be less than $200 \mathrm{cal} / \mathrm{g}$; ${ }^{*}$ however, we cannot exclude the possibility that it wil: be higher in some systems. Temperatures greater than $1000^{\circ} \mathrm{C}$ may be needed to effect the release of all stored energy with some wastes. The release will not be spontaneous unless there is a stepwise increase in temperature to a high level at which rapid release is initiated. After the wastes have been buried in a salt mine, stepwise increases in temperature are unlikely and, in turn, a spontaneous release of stored energy is improbable. Such increases in temperature, on the other hand, could occur under certain conditions during handling of a waste package prior to burial or in the course of a possible retrieval operation.

We also concluded that the radiation damage in radioactive wastes can be simulated in synthetic wastes, using fast-neutron or accelerator ion irradiations (alpha particles or protons). However, use of the latter

\footnotetext{
Blomeke and co-workers ${ }^{20}$ at ORNL have previously analyzed the effects on a salt repository of instantaneous release of $200 \mathrm{cal} / \mathrm{g}$ of stored energy within a waste can after burial. They concluded that a release $c \hat{2}$ this magnitude would be tolerable.
} 
type of irradiation is unattractive for one or more of the following reascns, depending on experiment design: (1) radiation damage effects in the necessarily small experimental samples may not be representative of those in bulk wastes; (2) high temperatur gradients within a sample during irradiation may affect energy storage; (3) accumulation of projectile-ions $\left(\mathrm{He}^{2+}\right.$ or $\mathrm{H}^{+}$) within a sample may affect energy storage; (4) the very high dose rates achieved during irradiation with accelerators may affect energy storage differently from the lower dose rates in the e.ctial wastes; and (5) the amounts of storea energy in the small samples may be difficult to measure. Fast-neucron irradiation is preferred in the stuly of energy storage in synthetic wastes. We recommend the Oak Ridge Reactor (ORR) for this purpose. Irradiations in the ORR for periods up to about 1 month would provide adequate tests of stored energy in sinivlated radioactive wastes.

We designed and constructed a Roux-type drop (to high temperature) calorimeter for use in our planned experimental work with synthetic wastes and with rock salt. The accuracy and the sample size requirements of our calorimeter at the $\mathrm{high}$ temperatures $\left(\sim 1000^{\circ} \mathrm{C}\right)$ that may be required for the waste samples are currently being investigate $l$ in calibration runs. Results to data indicate that this calorimeter will be satisfactory for measurements at 1000 to $i 200^{\circ} \mathrm{C}$ with waste samples weighing about $100 \mathrm{mg}$. It should ve possible to determine the stored energy with an accuracy greater than \pm cal/g, which will be adequate for our needs. The calorimeter is described below; the results of some preliminary measurements with irradiated halite and synthetic $\mathrm{NaCl}$ crystals are also presented.

Roux ${ }^{21}$ measured stored energy in irradiated oxides at $1200^{\circ} \mathrm{C}$ using a calorimeter similar to the heat-f].ow (quasi-isothermal) microcalorimeters employed in catalytic studies. $\bar{c} \hat{c}$ The samples were aropped into the calorimeter, which was maintained at a temperature above the point at which the stored energy was released. Gentrally, both the pre-drop and the calorimeter temperatures were eccurately measured; the transient cooling effect of the inner part of the calorimeter was determined by means of a thermopile and recorded. 
Our instrument (Fig. 2.8) differs from that used by Roux in two ways, which result in a der reased construction cost and a reduction in the rize cr sample required. First, we omitted the reference cell, which is commonly use i in heat-flow calcrimetry to reduce effects from furnace temperature fiuctuations. Instead, the constanny of the furnace temperature was maintained by direct means. The power for the furnace was provided by a dc supply which maintained a ce-stant voltage within about $0.2 \%$. The temperature regulator was eliminated in order to prevent the temperature fluctuation inherent in its operation; for this reason, an equilibrium period of a few days was required for the temperature to reach a corstant leve I after an appreciable adjustment, of the furnace voltage. The iustification for omission of the reference cell in high-temperature work is that differences in the radiative heat leaks between the reference and measuring cells (produced by thermal gradients in the furnace) make matching of the thermal characteristics of these cells very difficult. The poor heat conductivity of the ceramic insulation of the thermopile enhances the importance of radiative heat transfer. fdditionally, the space occupied by a reference cell would require a larger, more complex furnace in order to maintain the required low thermal gradients. Furthermore; the stringency of a constant base line for our work, in which measurements were completed within 5 min, was much iess than in applications of heat-flow calorimetry where measurements extend over longer periods.

The second simpljfication of our apparatus as compared with Roux's instrument was the omission of the suspension system by which the sample container was lowered into the calorineter. In place of this, we fabricated a sample container of sufficient design and strength to survive the impact received by directly dropping into the furnace.

The sample contajner was constructed by bending 5-mil platinum foil to form t,wo hollow cylinders, both of which wəre closed at one end. The top cylinder fit tightly inside the buttom cylinder and extended almost the full length of the bottom cylinder (Fig. 3.8). The seams if the bottom cylinder were welded to increase the resistance of the cylinder to impact. The seams of the top cylinder were not welded in order that its dimensions could be adjusted to make a tight fit with the bottom cylinder. This design 
204

ORNL-DWG T2-8123AI

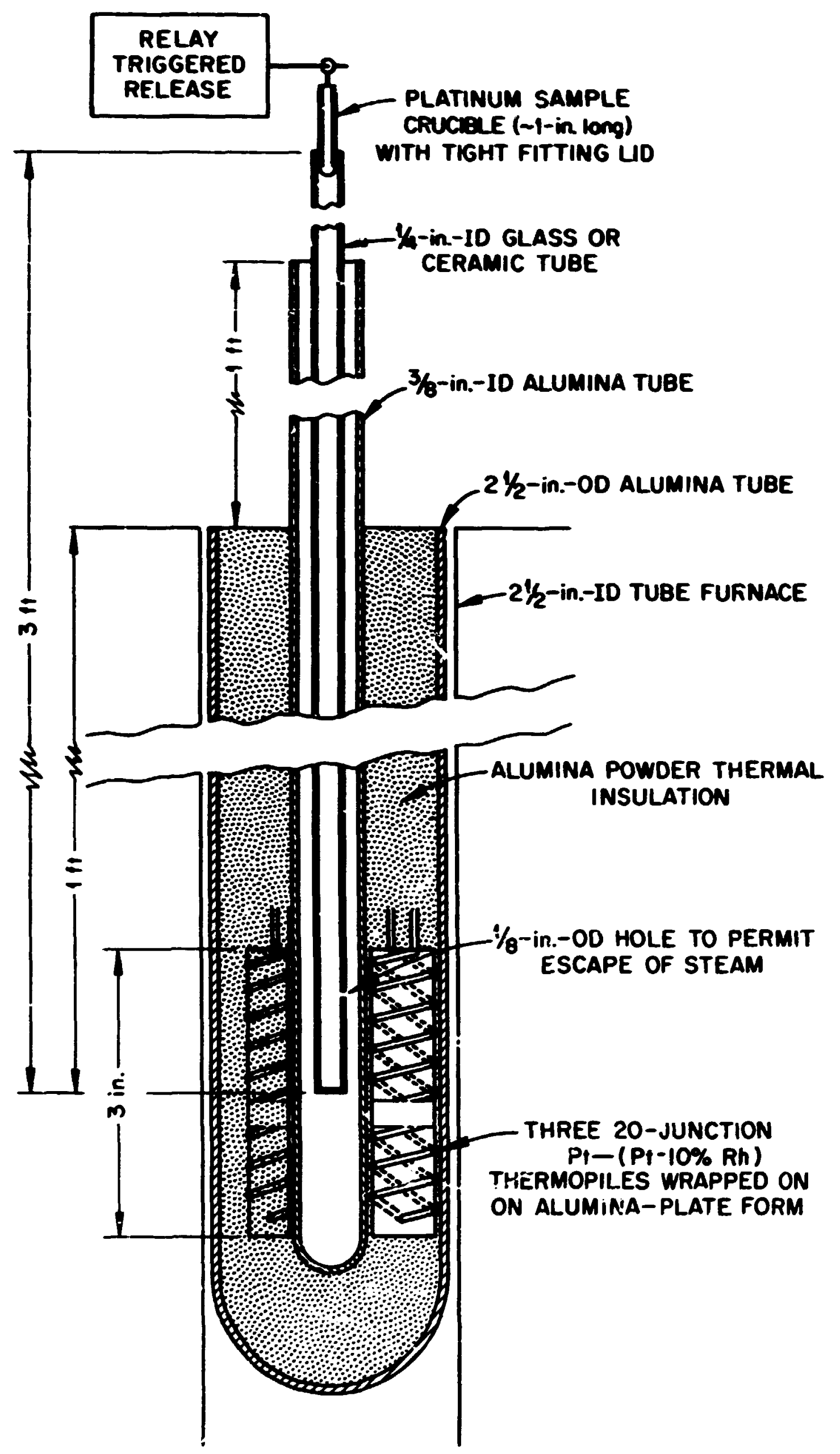

Fig. 3.8. Roux-type Drop Calorimeter. 
gave low thermal resistance between the top and bottom parts, which is particuisiriy important for reproducibility between measurements in wich the sample holder is disassemioled to change samples. Sample containers of two sizes were used. The larger one, 3/16 in. OD $\times 1$ in. Iong, had a capacity of about $0.5 \mathrm{~g}$ of $\mathrm{KaCl}$. Its dimensions were altered after several dmps, after which it was rebuilt. The smaller one. $3 / 32$ il. OD $\times 1 / 2$ in. long, was suitable fcr very smal? samples of sodium chloride (less than about $30 \mathrm{mg}$ ). It was quite resistant to the impect sustained an dropping. The withdrawal procedure consisted in engaging a book at the end of a 3-ft-long wire with a small wire loop attached to the sample container. The hook was lowered until it reached the top of the sample container, and was rotated to engage the loop. Usually, retrievai was accomplished within a few trials; however, from the necessity of writing "blind," success was not always achieved on the first attempt.

Generally, the reproducibility of calibration (as described below) is dependent on the method by wich the sample container is positioned in the instrument. Early in this work it was found that sample containers tc which spacers were attached had poor impact resistance. For this reason, positioning was accomplished by using a arop tube having a diameter only slightly larger than that of the sample ccntainer. A jifferent tube wes useã fnr each sample container size. The 1/8-in.-ID alumina tube used with the smaller container was placed inside a mullite tube, wich fit within the 3/8-in.-Il alumina tube. Thus, the smaller-diameter drop tube had more thermal shielding. In spite of this, however, the time-temperature curves for the thermopile signal did not differ greatly between the two sizes of drop tube.

In accordance with Roux's technique, about $90 \%$ of the thermopile signal was "bucked" out by a "tapered-transmission-line," electricalanaloy simulator, in order to reduce the accuracy required for the recording. Such a procedure is practical since the variation in signal between different samples is generally less than 10\%. The peak signal produced by the simulator was about $30 \mathrm{mV}$ for the larger sample container. This signal was reduced to the required "bucking" 3trength (about $300 \mu \mathrm{V}$ ) by a voltage divider, which was thermally insulated in order to avoid 
interference from thermal emfs. The difference in the simulator and thermopile outputs was amplified by a Leeds and Northrup 9829 linear amplifier, using the $30-$ and $100-\mu V$ ranges for the small and large sample containers, respectively.

Mst of our work has been concerned with dropping sample containers into a calorimeter maintained at $500^{\circ} \mathrm{C}$ (in connection with measuresient of stored energy in irradiated sodium chioride, although early work indicated a similar sensitivity at $1000^{\circ} \mathrm{C}$ ). The signal (the difference in emf between the thermopile and the simulator) is recorded for a few minutes in order to obtain the base line immediately prior to, and for about 5 min after, dropping the sample container. About 75 to $95 \%$ of the area under the plot of signal minus base line vs time is produced in the initial 5 min. The remainder is calculated by extrapolation of the exponential function determined by the data in the interval from 3 to 5 min. This method avoids effects from the drift of the base line at longer time spans, and was found to give gcod reproducibility. A waiting period of about $60 \mathrm{~min}$ is required for return of a constant base ine on the conclusion of an experiment. The calibration parameter, $C\left(\operatorname{cei} \min ^{-1} \mu V^{-1}\right)$, is calculated from:

$$
C=\Delta H\left(W_{2}-W_{1}\right) / \int_{0}^{\infty}\left(S_{2}-S_{1}\right) d t,
$$

where $\Delta H$ is the change in heat content, in calories per grari, ce a standard material (in this case, $\mathrm{NaCl}$ was used) on increase of its initial temperature to the calorimeter temperature; $k_{2}$ and $k_{2}$ are different weights of the standard used in experiments $I$ and 2 , respectively; and $S_{1}$ and $S_{2}$ are the signal-vs-time functions determined in the two experiments.

The calibration parameter was found to be independent of sample weight, as shown in Table 3.4. This is in agreement with the results ootained by Roux. The values of $\mathrm{C}$ for the larger and smaller sample contoiners were 0.044 and $0.070\left(\mathrm{cal} \mathrm{min}^{-1}, \mathrm{~V}^{-1}\right)$, respectively. The difference vetween these two values probably reflects the greater thermal shielding for the smaller sample-container - drop-tube combination, as was mentioned previously. In most experiments, the accuracy of calibration was linited to about $5 \%$ by either the accuracy to which the initial temperature of the 
sample container was measured or the accuracy of weighing the samples. This could be improved (in work which justified the extra time involved) by more accurate weighings and temperature measurements.

Table 3.4. Calibration Constant of Larger Sample Container

\begin{tabular}{|c|c|c|c|}
\hline \multicolumn{4}{|c|}{ Sample wieight (g) } \\
\hline Date & Larger & Smaller & c \\
\hline $\begin{array}{l}6-24-72 \\
7-24-72\end{array}$ & $\begin{array}{l}0.242 \\
0.139\end{array}$ & $\begin{array}{l}0.192 \\
0.113\end{array}$ & $\begin{array}{l}0.043 \\
0.044\end{array}$ \\
\hline
\end{tabular}

The energy stored in several irradiated $\mathrm{NaCl}$ samples was determined by dropping the sample container twice into the furnace maintained at about $500^{\circ} \mathrm{C}$ in each case. (The stored energy was released rapidiy in the first drop.) The stored energy, E (in calories per gram), was calculated from:

$$
E=(C / W)\left(\int_{0}^{\infty} s_{2}-S_{1}\right) d t,
$$

where $W$ is the sample weight (in grams), $S_{1}$ and $S_{2}$ are the signal-vs-tine functions determined in the first and secord drops, respectively, and $G$ is the parameter determined by Eq. (1).

Best results were obtained by dropping sample containers having a temperature greater than aboul: $95^{\circ} \mathrm{C}$ since there was generally interference from adsorbed moisture at lower temperatures. In work at lower temperatures, it appeared that more moisture was adsorbed by irradiated samples prior to the first drop than after the radiation defects har keen annealed. A good test for the absence of moisture effects was to couluct different experiments in which the area/volume ratio was changed by decreasing the particle size, but in which the other conditions were similar. If the results were nesrly independent of particle size, reliance could be placed on those sbtained with the large particle size. Best results have been obteined with artificial $\mathrm{NaCl}$ crystals that were crystallized from a melt and that, therefore, did not contain inclusions of liquid. 
To dite, insufficient work has beex done to detsrmine the full extent of interference from inclusions of brine in natural halite; however, since the small samples which have been used remained intact after being drooped into the calorimeter, any release of brine is probably confined to nearsurface inclusions. It is thought likely that the release of brine may occur only in infrequent experiments sucin that statistical rejection of such experiments is practical.

\subsubsection{Energy Storage in Rock Sait (G. H. Jenks, C. D. Bopp)}

The rock salt that sirrrounis a can of high-level radioactive waste in a salt repository will is exposed to high gamma-ray doses and intensities (maxima of $\sim 2 \times 10^{1:} \mathrm{rac} 3$ and $\sim 5 \times 10^{5} \mathrm{rads} / \mathrm{hr}$ ) and to elevated temperatures ranging up to about $330^{\circ} \mathrm{C}$. Some of the absorbed gama-ray energy will be stored as lattice disorder within the salt crystals under some or all of the exposure conditions. Knuwledge of the emounts that will be stored is needed for evaluations of the hazards which would be associated with rapid release of the stored energy by thermal annealing.

Available experimental and theoretical information indicated that the amount of stored energy will depend on $d^{-}$se rete, dcise, and temperature, bui this information was too measir to permit extrapoiation to repository conditions. 28 We initiated an experimental investigation aimed at providing data that will permit exirapolation to repository conditions, and we designed and are constructing equipment for making experimental gemma irradiations of salt within the target rezion of spent HFIK fuel elements (dose rates up to $10^{\circ} \mathrm{rads} / \mathrm{hr}$, doses to $>2 \times 10^{10}$ rads, and temperatures to about $330^{\circ} \mathrm{C}$ ). We also studied the energy stored in samples of synthetic crystais of $\mathrm{KaCl}$, supplied to us by $\mathrm{E}$. Sonder of the Solid State Division, after gemma irradiation at $10^{7} \mathrm{rads} / \mathrm{hr}$. This work is sumarized below.

Description and Str.tus of Gamma Irradiation Facility. - Our HFIR gamm irradiation facility crasists, basically, of a 3-in. NPS sched 10S stainless steel pipe extending ficm the space above this top of the HFIR pool into the target region of a spent ifir fuel element on the bottom of the pool. The pipe prorides a conduit through wich the specimen holder, specimens, and associated equipment are inserted into and withdrawn from the gamma field of the fuel element. The top of the access 
pipe is equipped with 5 flanged closure, which includes leads for passages of electrical and gas conductors. The specimen holder is 2 in. in outside dimmeter and 12 in. long. It will accommodate a variety of specimens simultaneously, incliding those with dimensions $1 / 2 \times 1 / 2 \times 3$ in., which may be needed in tive st:ady of thermal conductivity of irradiated salt.

Since the access pipe is immersed in water, it is necessary to consider the $x$ ssibility that water will enter the pipe in some manner and that rejiolysis of this water will produce explosive gas mixtures. To eliminate the possibility that an explosive gas mixture will be formed, helium gas is passed over the capsule and through the access pipe at a rate in excess of that required to dilute any radiolytic gas to a concentration below the explosive limit. The initial system with one purge line is presently being modified to provide for dual, redundant purs. lines. We believe that this system, with associated flow detectors and nlarms, will provide adequate assurance that no accumulation of explosive gas mixtures will take place.

Stored Energy in Gamma-Irradiated NaCl. - E. Sonder of the Solid State Division has supplied us with samples of Harshar synthetic crystals of $\mathrm{NaCl}$ that were irradiated in a $10^{7}-\mathrm{rad} / \mathrm{hr}$ cobalt source. We analyzed these samples for stored energy using the drop calor imeter at $500^{\circ} \mathrm{C}$. The results of thise measurements, together with results of heat-of-solution measurements which have been reported by oticers, are listed in Table 3.5. Descriptive information on the samples and on the drop calorimeter measurements is also included in the table.

As stated in the footnotes of Table 3.5, the stored energy in sample 2 apparently decreased during preheating at $113^{\circ} \mathrm{C}$. Thermal annealing at $15^{\circ} \mathrm{C}$ above the temperature of irradiatinn was unexpected, and it did not occur with sample 1 (which had received the higher dose). The values for 3ample 2 (see Table 3.5) are for those for which no annedinis was apparent.

Thermal analyses of sample 1 with the drop calorimeter (Table 3.5) gave stored-energy values that exceeded by factors of 1.7 to 2 those reported by others who used heat-cf-solution calorimeters. At least part of the difference between the results of the two calorimetric methods 
Table 3.5. Results of Stred-phergy Measurements on Synthet1c NaCl Crystals Gamma-Irradiated at $10^{7} \mathrm{Rads} / \mathrm{hr}$ and $95 \pm 5^{\circ} \mathrm{C}^{\mathrm{a}}$

\begin{tabular}{|c|c|c|c|c|}
\hline $\begin{array}{l}\text { Sample } \\
\text { lio. }\end{array}$ & $\begin{array}{l}\text { Dose } \\
\text { (rads) }\end{array}$ & Bxperimenter & Method & Results \\
\hline \multirow[t]{3}{*}{1} & $1.5 \times 10^{10}$ & $\begin{array}{l}\text { G. E. Soyd and } \\
\text { M. J. Mastrolann1 b }\end{array}$ & Heat of Solution & 7.8 and 8.6 \\
\hline & & $\begin{array}{l}\text { S. Iindenbaum } \\
\text { (Univ, of Kansas) }\end{array}$ & Heat of solution & 7.1 and 7.3 \\
\hline & & C. D. Bopp & $\begin{array}{l}\text { Thermal analysia with } \\
\text { drop calorimeter }\end{array}$ & $\begin{array}{l}14.3^{\mathrm{c}} \\
14.7^{\mathrm{d}} \\
24.8^{\mathrm{e}}\end{array}$ \\
\hline 2 & $4.3 \times 10^{\circ}$ & C. D. Bopp & $\begin{array}{l}\text { Thermal analysis with } \\
\text { drop calorimeterh }\end{array}$ & $\begin{array}{l}8.5^{f} \\
9.0^{8}\end{array}$ \\
\hline
\end{tabular}

asamples of Harshaw synthetic crystals Irradiated and supplied by E. Sonder of the Solid State Division; privete commurication from E. Sonder, August 1972. These samples were black, indicating the presence or colloldal sodiun.

Besaurements quoted by E. Sonder, private communication, Augunt 1972.

CHeated at $105^{\circ} \mathrm{C}$ for $1 \mathrm{hr}$, then dropped from room temper ature.

Heated at $111^{\circ} \mathrm{C}$ for $35 \mathrm{~min}$ and dropped directly from that temperature.

Hoateci at $95^{\circ} \mathrm{C}$ for $30 \mathrm{~min}$ and dropped directly from that tumerature.

fleated at $92^{\circ} \mathrm{C}$ for $28 \mathrm{~min}$ and dropped direcilly from that temperature.

BHeated at $95^{\circ} \mathrm{C}$ for $33 \mathrm{~min}$ and dropped directly from that temperature.

${ }^{h}$ Initial thermal analyses of two samples of this materiul were arde after heating the samples at $113^{\circ} \mathrm{C}$ for 40 and $60 \mathrm{~min}$, respectively, and then dropplng them directly into the furnace from that temperature. The reapizctive stored-energy values were 5 and $4 \mathrm{cal} / \mathrm{s}$. Some thermal annealing apparently occurred during this preheating. 
can be reasonsitiy explained by assuming that aqueous dissolution of trapped eiectrons and holes results in the formation of certain other species in addition to $\mathrm{Na}^{+}$and $\mathrm{Cl}^{-}$(Sect. 3.2.3). A maximum difference factor in the range 1.5 to 2.8 has been estimated due to this effect. Experimental errors may siso account for some of the difference.

The stored-energy values in Table 3.5 are much higher than the values (approximately $1 \mathrm{cal} / \mathrm{g}$ ) previously reported by sonder and Linderitenim 20,23 for synthetic $\mathrm{NaCl}$ crystals that had been irradiated by van de Graaff electrons at higher dose rates $\left(>10^{\circ} \mathrm{rads} / \mathrm{hr}\right)$ and at texperatures $580^{\circ} \mathrm{C}$. The reason for this difference remains to be established. ilowever, a conceivable explanation is that a dose-rate effect exists in wich migration and slustering of defects into relatively stable aggregates (colloids) 24-27 become important at the long exposure times prevailing at the iower dose rates.

The storeci-energy values that were obtained for samples 1 and 2 with the arop salorimeter show an approximte square-root dependence on dose. 3.2.3 Radiation and Thermal Chemistry (G. H. Jenks)

Solutes Formed upon Dissolution of Trapped Fiectrons and Holes in Irradiated $\mathrm{FaCl}$, and Their Effects upon Heat of Solution. - Danage produced in NaCl by the ionizing action of nuclear radiation is compised of displaced atoms and of trapped electrons and holes. Chemically, the trapped electrons and holes are reducing and oxidizing agents, respectively; and dissolution of radiation-damaged faCl results ir the injection of oxidizing and reducing agent.s inio the aqueous solution. ${ }^{21,22}$ The oxidizing agent entering solution corresponds to $\mathrm{Cl}^{\circ}$, and possibly $\mathrm{Cl}_{2}$, wille the reducing agent can be treated as a hydrated electron, $\mathrm{e}_{\mathrm{aq}}^{-}$, or as $\mathrm{Na}^{\circ}$. The products formed by aqueous dissolution of these species may differ from those formed by dissolution of unirradiated saIt ( $\mathrm{Ha}^{+}$and $\mathrm{Cl}^{-}$only). Information on the identities and amcunts of the products is of interest in connection with evaluations of reported resilts of measurements of heats of solution of irradiated $\mathrm{NeCl}$. Such information 18 also of interest in our overall efiort to establish the radistion and thermal characteristics of the brine inclusions. 
We consulted oux previcus review 28 of avilable information on radiation and thermal chemistries of salt mine brines to select likely reactions of the trapped electrons and holes upon aqueous dissolution, and for these we calculated the difference between the heat of reaction and the heat of the reference reaction in which only $\mathrm{Ka}^{+}$and $\mathrm{Cl}^{-}$are formed froc the defects. We also studiel the $\mathrm{pH}$ of solutions of irradiated salt in order to belp pinpoint the reactions of the defects.

Sane possible dissolution reactions of trapped electrons and holes are represented by those listed in Table 3.6. The footnotes show the partia]. reactions 28 and al; 50 elaborate on the manings and the sigmificance of the listed values. The derivation of the raction given in footnote $i$ is described in Table 3.7. In addition, wo note that an increase in $\mathrm{pH}$ is expected for some of these overall reactions, while no change in $\mathrm{pH}$ is expected with others. Reactions other than those given in Table 3.6 are corceivable but less probable. Those we have exwined have values of $\mid \Delta H$ - $\Delta H_{\text {ref }} \mid$ less than $1.7 \mathrm{eV}$.

The results of our $\mathrm{pH}$ measurenents and sone analyses of the pH data are I: ted in Table 3.8. These results show that the concentration of $H^{+}$ formed upon dissolution of irradiated salt is much less than that expected if trapped electrons and holes react to form $\mathrm{H}^{*}$ plus $\mathrm{g}$ plus $\mathrm{OH}$, and $\mathrm{Cl}^{-}$ plus $\mathrm{H}^{+}$plus EOCI and OCI-, respectively (see Case 1, Table 3.6). Reactions and/or conditions wich are consistent with these results are listed below. Other evidence supporting or discounting the given reactions is as follows:

(1) Reaction of $98.5 \%$ of the defects accordias to Case 2, 4, or 5 (Table 3.6) would result in the small $\mathrm{pH}$ changes that were observed. To tentatively distinguish betwen these, we note that evolution of gas is observed when irradiated salt is dissolved in mater. We sote that other worker $8^{30}$ bave reported that the evolved gas is composed of 95 to $99 \%$ 8 ; Case 4 reactions are thus supported by this evidenc.

(2) Reaction of $98.5 \%$ of the defects to form only $\mathrm{Ba}^{+}$and $\mathrm{Cl}^{-}$upon dissolution would result in the small $\mathrm{pH}$ changes that were observed. However, this possibility 13 discorunted by the gasevelution evidence. 
Toble 3.6. Possible Aqueons DAssolution Reactions of Radiation Deferts in InCl, and

Coppariscons Butween Eents of Dissolution and the Stored Brergs vithin the Crystel

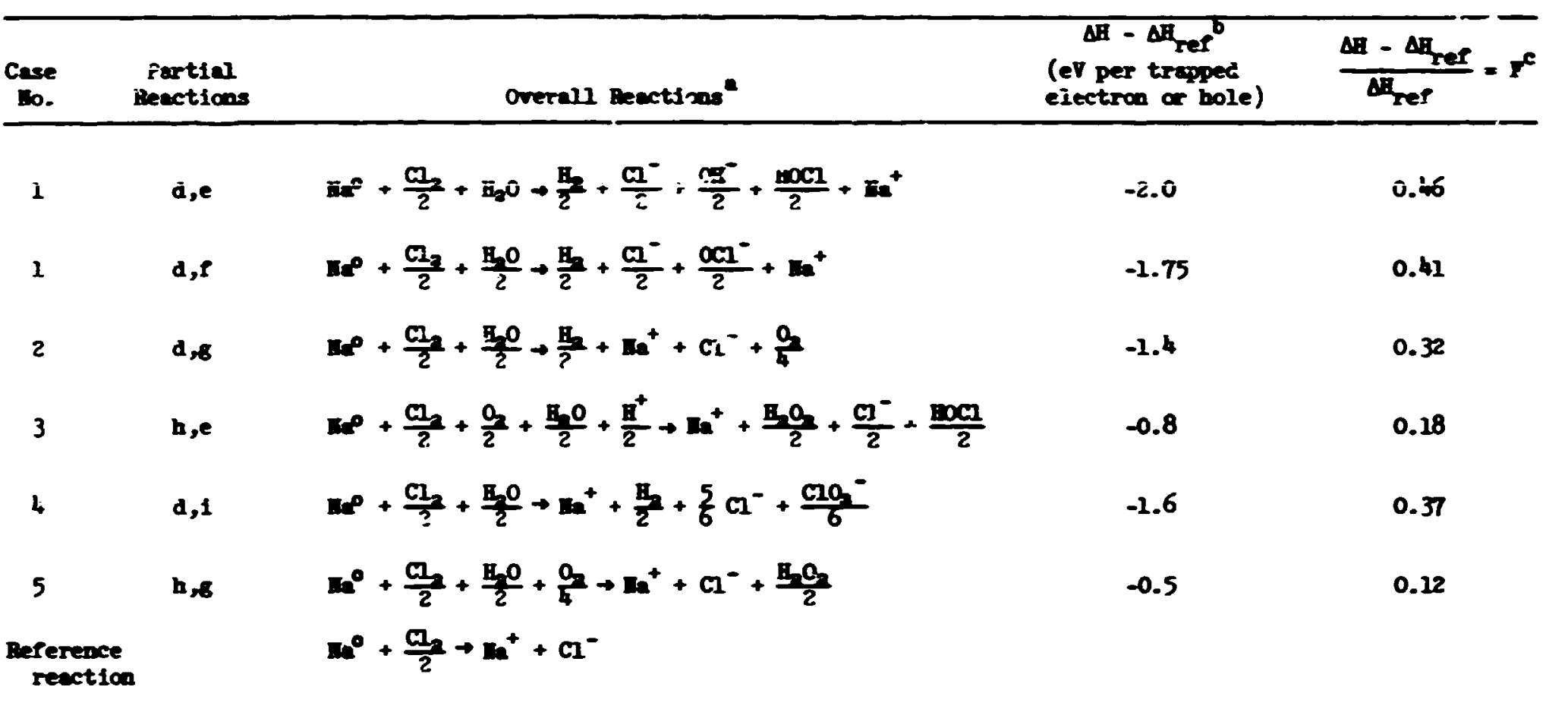

The specific chenical and phrsical form of the trapped electrons and boles are not specified in these reactions. Ine and $\frac{\mathrm{C}_{\mathrm{Q}}}{2}$ are merels illustrative of conceivable form.

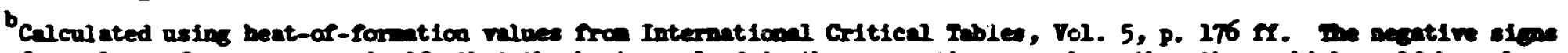

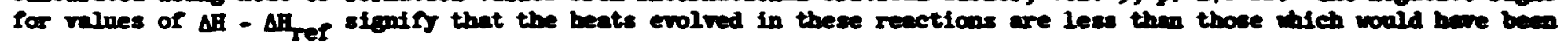
evolved if only $\mathrm{Ha}^{+}$and $\mathrm{Cl}^{-}$had bees formed from the defecte.

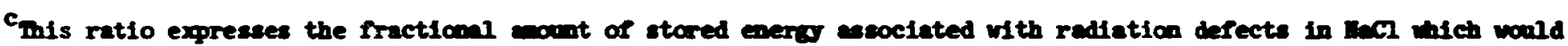
be aissed in a solution calorineter neasurenent. The ectual valne of af per is uncertain. The listed vilus of $F$ were obtained by asw ing that the defects are present as elenental sodive mod chlorine so that ar fer equals the heat of formetion of crystalline iacl, 4.3 eV per $\mathrm{Ea}^{+} \mathrm{Cl}^{-}$

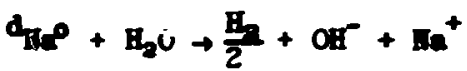

$\frac{{ }^{C} \mathrm{CL}_{2}}{2}+\frac{\mathrm{E}_{\mathrm{O}}}{2} \rightarrow \frac{\mathrm{CI}^{-}}{2}+\frac{\mathrm{B}^{+}}{2}+\frac{\mathrm{BOCl}}{2}$

$\frac{\mathrm{CI}_{2}}{2}+\frac{\mathrm{B}^{0}}{2} \rightarrow \frac{\mathrm{CI}^{-}}{2}+\mathrm{H}^{+}+\mathrm{OCI}^{-}$

$\frac{\mathrm{CO}_{2}}{C_{2}}+\frac{\mathrm{B}_{2} \mathrm{O}}{2} \rightarrow \mathrm{H}^{+}+\mathrm{CI}^{-}+\frac{\mathrm{O}_{2}}{4}$

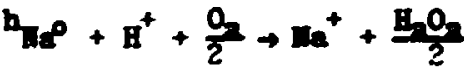

${ }^{1} \mathrm{Cl}_{2}+\frac{\mathrm{HO}_{2}}{2}+\mathrm{H}^{+}+\frac{5}{6} \mathrm{Cl}^{-}+\frac{\mathrm{COO}^{-}}{6}$ 
Table 3.7. Derivation of Equation in Fcotnote $i$, Table 3.6

$$
\begin{array}{ll}
2 \mathrm{Cl}^{\circ}+2 \mathrm{Cl}_{3}+2 \mathrm{H}_{3} \mathrm{O} \rightarrow 4 \mathrm{H}^{+}+4 \mathrm{CI}^{-}+2 \mathrm{Cl}^{\circ} & (1)^{28,29} \\
2 \mathrm{Cl} 0^{\circ}+\mathrm{H}_{3} \mathrm{O} \rightarrow 2 \mathrm{H}^{+}+\mathrm{Cl}^{-}+\mathrm{ClO}_{3}^{-} & (\Sigma)^{29}
\end{array}
$$

Combine Reactions (1) and (2):

$$
2 \mathrm{Cl}^{\circ}+2 \mathrm{Cl}_{2}+3 \mathrm{H}_{3} \mathrm{O} \rightarrow 6 \mathrm{H}^{+}+5 \mathrm{Cl}^{-}+\mathrm{ClO}_{3}^{-}
$$

Rewrite Reaction (3):

$$
\frac{\mathrm{Cl}^{0}}{3}+\frac{\mathrm{Cl}_{2}}{3}+\frac{\mathrm{H}_{2} \mathrm{O}}{2} \rightarrow \mathrm{H}^{+}+\frac{5}{6} \mathrm{Cl}^{-}+\frac{\mathrm{ClO}_{3}^{-}}{6}
$$

Neglect the explicit distinction between $\mathrm{Cl}^{\circ}$ and $\mathrm{Cl}_{3}$. Then, Reaction (4) can be rewritten as Reaction (5):

$$
\frac{\mathrm{Cl}_{2}}{2}+\frac{\mathrm{H}_{2} \mathrm{O}}{2} \rightarrow \mathrm{H}^{+}+\frac{5}{6} \mathrm{Cl}^{-}+\frac{\mathrm{CIO}_{3}^{-}}{6}
$$

which is identicel with the reaction given in footnote $\&$, Table 3.6 . 
Taile 3.8. Results of pH Measurements on Solutions of Irradiated Salt and Analyses of pH Date

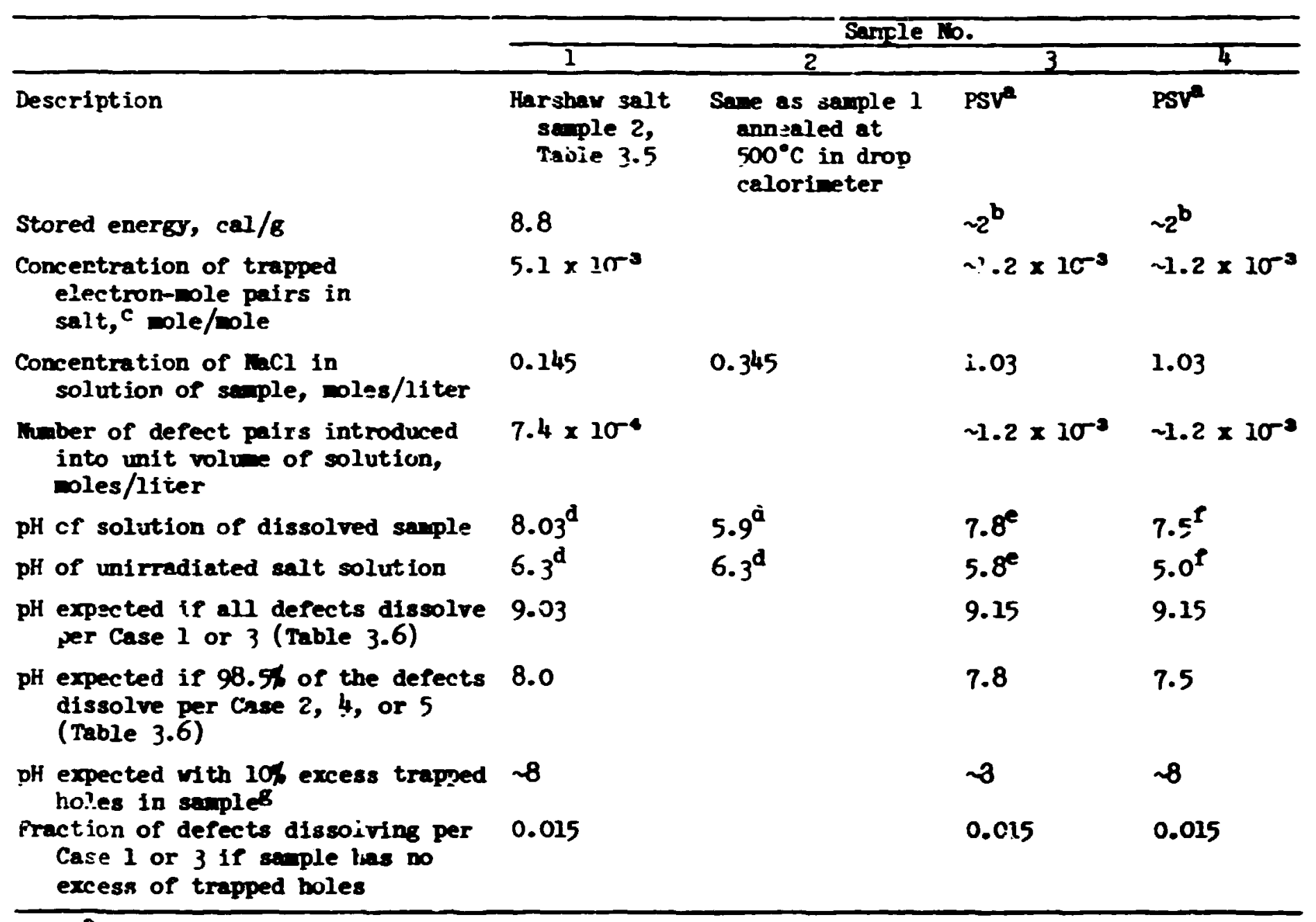

asamles from Project Salt Vault, Hole 6.

balues deternined with drop calorineter.

${ }^{c}$ Calculated assuning $4.3 \mathrm{eV}$ per trapped electron-bole pair. The heat of formation of crystalline $\mathrm{raCl}$ is $4.3 \mathrm{eV}$ per $\mathrm{Ka}^{+} \mathrm{Cl}^{-}$molecuie.

${ }^{d}$ Solvent was boiled and cooled, defonized water. Solutions 0.01 to $1.0 \mathrm{~m}$ in unirradiated Lyons salt had a pH of 6.3.

Unbolled, defonized water. Solutions 0.005 to $1.0 \mathrm{~N}$ in unirradiated frons salt showed a pll of 5.9. This low $\mathrm{pH}$ was probably due to $\mathrm{CQ}_{2}$.

friply distilled weter. Solutions 0.01 to $1 /$ in unirradiated lyons salt showed a pH of 5.0 . This low pll was probably ciue to IKI rontaminant in the still.

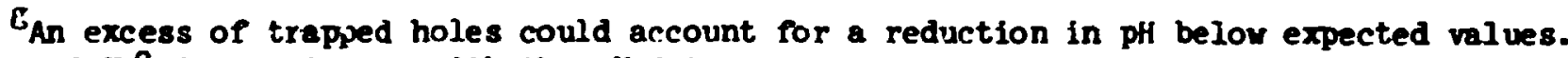
excess of $\mathrm{Na}^{\circ}$ is consistent with the $\mathrm{pH}$ data. 
(3) Ail or most of the defects react according to Case 1, but the trapped holes are in $10 \%$ excess. Ioss of $\mathrm{Na}^{\circ}$ from the crystal would be necessary to produce the excess holes, and this seems unlikely.*

For cases 1 through 5, calculated values for the quantities $\Delta H-$ $\Delta H_{\text {ref }}$ and $F$ are presented in Table 3.6. F represents the fractional amount of stored energy which is omitted in a heat-of-solution measurement. The value for this quantity depends on the energy associated with the defects within the crystal. The lowest value for this latter quantity is probably the value for winich the defects occur as clusters of elemental sodium and chlorine (i.e., $4.3 \mathrm{eV}$ per defect pair). Higher energies may be associated with F-centers; $4.6 \mathrm{eV}$ and $5.6 \mathrm{eV}$ per F-center 31,32 are recently reported values. We used the value of $4.3 \mathrm{eV}$ to calculate the values of $F$ in Table 3.6 .

For Item (3) above, assuming that the defects xccur as elemental sodium and chlorine, the heat of dissolution per $\mathrm{Na}^{\circ}$ is $1.8 \mathrm{eV}$ less than the heat of formation of $\mathrm{Na}^{+} \mathrm{Cl}^{-}$and the value of $\mathrm{F}$ is 0.41 (if no stored energy is essociated with excess chlorine).

Composition of Encapsulated Brine in Iyons Salt. - Two different samples** of bxine from the Lyons salt were analyzed ${ }^{\dagger}$ for $\mathrm{Na}$, $\mathrm{Mg}$, and $\mathrm{Ca}$ by emission spectrcscopy. The results were in agreement within the precision of the anelytical method, $\pm 5 \%$ (Table 3.9). Also, these results were consistent witi information obtained on the solubility of $\mathrm{KaCl}$ in solutions of $\mathrm{MgCl}_{2}$, an. 1 with previous information on the composition of brine inclusions in salt from a mine at Hutchinson, Kansas. 28

The present samples wero obtained, in each case, by cleaving a $\mathrm{NaCl}$ crystal to expose a brine inclusion, immediately collecting the brine in

\footnotetext{
*The pH results show that there is no excess of $\mathrm{Na}^{\circ}$ in the salt (i.e., no loss of chlorine occurred).

** Brine samples were collected by A. L. Sutton of the Reactor Chemistry Division.

tChemical analysis was made by the ORNL Analytical Division.
} 
a capillary via capillary action, and then immediately transferring the sample into an $\mathrm{HCl}$ solution in a small flask. Previous samples that had been allowed to stand within the capillaries for long periods ( 1 day) gave nonreproducible and inconsistent results.

Table. 3.9. Results of Analyses of Encapsulated Brine from Lyons Salt

\begin{tabular}{|c|c|c|c|c|c|c|c|}
\hline \multirow[b]{3}{*}{ Element } & \multicolumn{7}{|c|}{ Amount in Sample } \\
\hline & \multicolumn{3}{|c|}{$\mu \mathrm{g}$} & \multicolumn{4}{|c|}{$\bar{M}$} \\
\hline & No. $1^{a}$ & 15. $2^{6}$ & $15 \cdot 3^{c}$ & No. 1 & 15o. 2 & No. 3 & Hutchinsond \\
\hline $\mathrm{Na}$ & 44 & 19 & - & 1.89 & 1.92 & - & $2-1$ \\
\hline $\mathrm{Mg}$ & 50 & 23 & 31 & 2.03 & 2.21 & 1.6 & $2 \cdot 3-3$ \\
\hline $\mathrm{Ca}$ & 1.3 & 0.7 & - & 0.03 & 0.03 & - & Negligible \\
\hline $\mathrm{Br}$ & - & - & 1.7 & - & - & $\begin{array}{c}0.03 \\
(0.04) e\end{array}$ & 0.05 \\
\hline
\end{tabular}

${ }^{2}$ Sample volume $=0.00101 \mathrm{~cm}^{3}$.

bSample volume $=0.000428 \mathrm{~cm}^{3}$.

ESample volune $=0.000774 \mathrm{~cm}^{3}$. salt. ${ }^{28}$

dPreviously estimated from Holser's data for brine from Hutchinson

eAfter adjustment for possible loss of sample, as indicated by results for magnesium.

A spark-source mass spectrometer analysis for bromine was made on one of the previous samples, using ${ }^{81} \mathrm{Br}$ as an internal standard. The concentration of magnesium in this sample, as determined by emission spectroscopy, was $1.6 \mathrm{M}$. The unadjusted value for bromine was $0.03 \mathrm{M}$. After adjustment for possible loss of sample as judged from the magnesium result, the bromine value was $0.04 \mathrm{~N}$. Both values are in reasonable agreement with those previously estimated from Holser's data for Hutchinson salt. 28 However, it is notable that the magnesium concentration [Mg] is $2.1 \mathrm{M}$ rather than the maximum of $3 \mathrm{M}$ which we previously estimated. Accordingly, the maximum rate of formation of $\mathrm{HCl}$ from the hydrolysis of $\mathrm{MgCl}_{2}$ is about two-thirds of the valie previously used.

Most of the brine inclusions in the Lyons salt which we have examined are not completely filled with liquid; that is, each generally contains a small gas-phase bubble. Presumably tinese bubbles contain air which was 
dissolved in the brines when the salt crystals were formed. We were interested in the amounts of air present in such bubbles from the standpoint of designing brine-radiolysis experiments that will simulate exposure conditicns within a salt repository.

The results of the following simple tests on three different brire inclusions led us to conclude that the gas pressure within a cavity is 1 atm or less. In each of two such jnclusions, a 20-mil hole was arilled th:ough the crystal so that the drilled hole tapped the inclusions on a side near the bottom (a low-power microscope was used). Ho expansion of the bubble took place wher the cavity was breached. However, air bubbles did enter the cavity, pass up through the liquid, and then jcin the original bubble. The third cavity was tapped (with a 20-mil drill) near the top; in this case, the bubble collapsed (possibly due to pressure from the drill) before air entered the cavity.

The relative volumes of gas and liquid within cavities can be inferred from the reported results of previous workers with salt, taken from the 900ft level of the Americun Salt Corporation mine at Iyons. 33 These investigators reported values for relative volume:s of gas and liquid ranging from 0 to 0.04 . They also reported that the bubbles disappear at temperatures from 70 to $100^{\circ} \mathrm{C}$.

We concluded that the maximum concentration of air within the brine will be about $0.002 M$ and, accordingly, that the effects of this air on radiolysis will be negligible relative to the concentrations of radiolytic products ( $>0.01 \mathrm{M}$ at the least) with which we are likely to be concerned.

\subsubsection{Effects on Physical Properties (T. G. Godfrey, D. L. McFlroy, S. H. Jury*)}

The thermal and muclear enviroment of the materials surrounding the waste containers, after their emplacement in the salt mine, will be quite different from that which these materials normally experience. Accordingly, it is necessary to establish the effects of this enviriment, singly and in combinaticn, on the more important physical properties of the salt ani its associated impurities. Our experimental program consists of thermal

*Consultant from the liaiversity of Tenressee, Knoxville. 
cordustivity measurements on both unirradiated and irradiatied solid se.t, vii crushed salt backfill, and on crushed salt as it experiences reconsolidation due to compressive stress and temperature. An automatic const,ant-temperature ice bath wes developed for use with these measurements. An experiment that simulated short-time conditions experienced by a waste container in an unlined hole was also performed.

Thermal Conductivity of Unirradiated and Irradiated Solid Salt. Our experimental program son measuring tine thermal conductivity of solid salt is in the formative stage. We intend to use both pure $\mathrm{kaCl}$ and natural rock salt for our measurements, covering the temperature range 80 to $900^{\circ} \mathrm{K}$. Samples in the form of $1 / 2 \times 1 / 2 \times 3$ in. bars will be measured in a low-temperature longitudinal device ${ }^{34}$ over the range 80 to $400^{\circ} \mathrm{K}$; for the range 300 to $900^{\circ} \mathrm{K}$, we will use 3-in.-dian disks in a radial heat flow apparatus. 35 These experiments wili provide bese-line data for subsequent measurements on salt bars and small disks irradiated at two different temperatures, two dose rates, and two total doses. The irradiated salt bars will be measured in the longitudinal device from 80 to $400^{\circ} \mathrm{K}$, and the $\operatorname{small}(1 / 2 \times 1 / 2$ in.) disks will be measured in a comparative device ${ }^{36}$ at $300^{\circ} \mathrm{K}$.

Thermal Conductivity of Salt Powder. - We measured the thermal conductivity of two samples of crushed natural salt in air and in argon $2 s$ a function of temperature over the range 300 to $850^{\circ} \mathrm{K}$ in a radial heat flow apparatus. 37 The Hutchinson sal , samples, supplied by H. W. Godbee of the Chemical Technology Division, were identified as "fine" and "medium," and had the particle size distributions shown in Fig. 3.9. We determined that the "nedium" sample would not uniformly pack in the a.pparatus; therefore, we adjusted the size distribution by screening and blending to approximate the distribution range of the "fine" (but coarser by a factor of 5 ), as shown hy the dashed line in Fis. 3.9. This blended "medium" sample would iniformly pack to the $60 \%$ bed density chosen for both powder experiments.

The results obtained for the "fine" salt samples are shown in Fig. 3.10. The chronology is indicated since powder samples often show an irreversible behavici ane to thermal expansion efsects, particle 


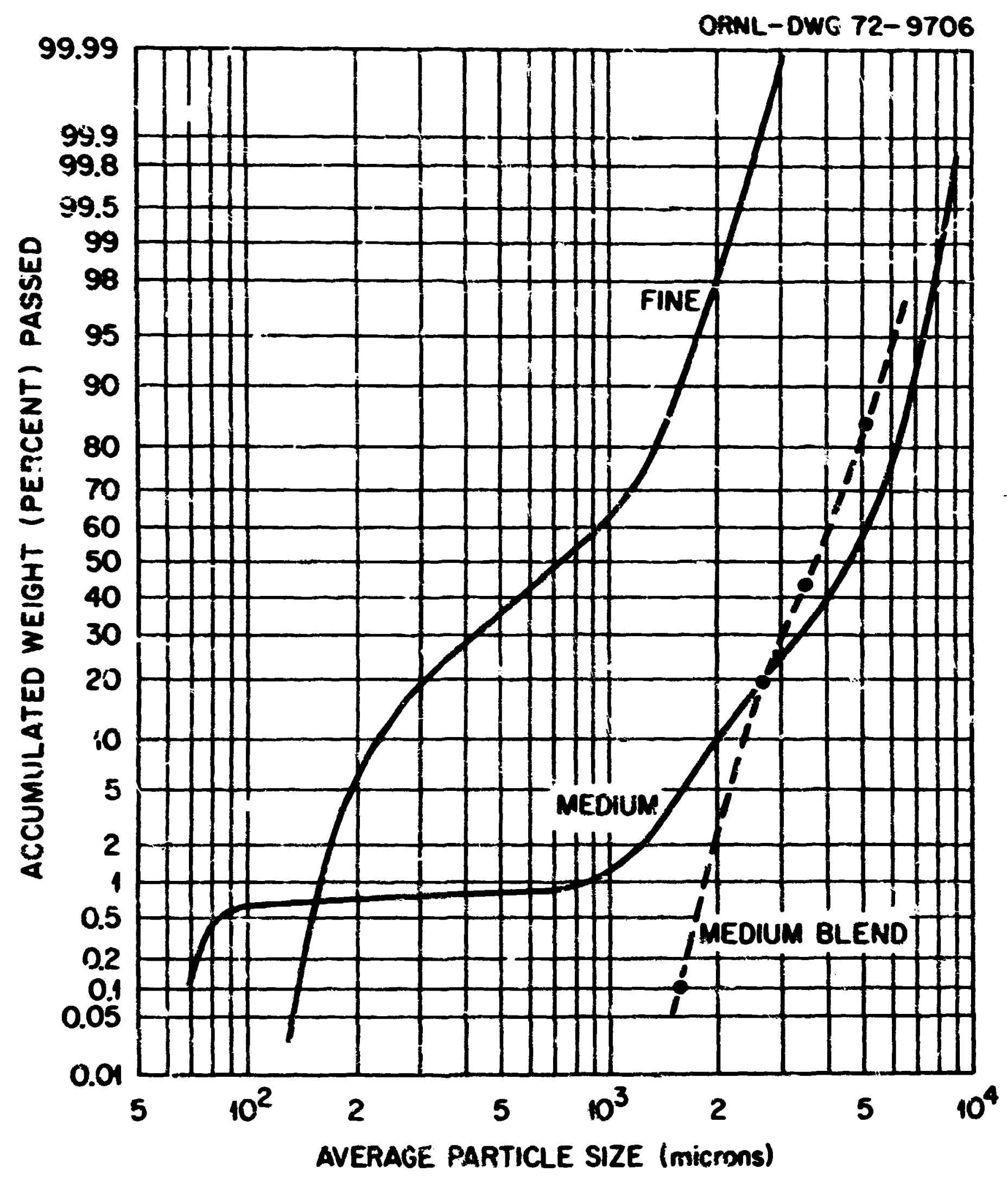

Fig. 3.9. Particile Size Distributions of "Pine" and "Medilin" Hutchinson Salt Porder and of the "Blended Mediun" Samle Used for Thernal Conductivity Seasurements. 


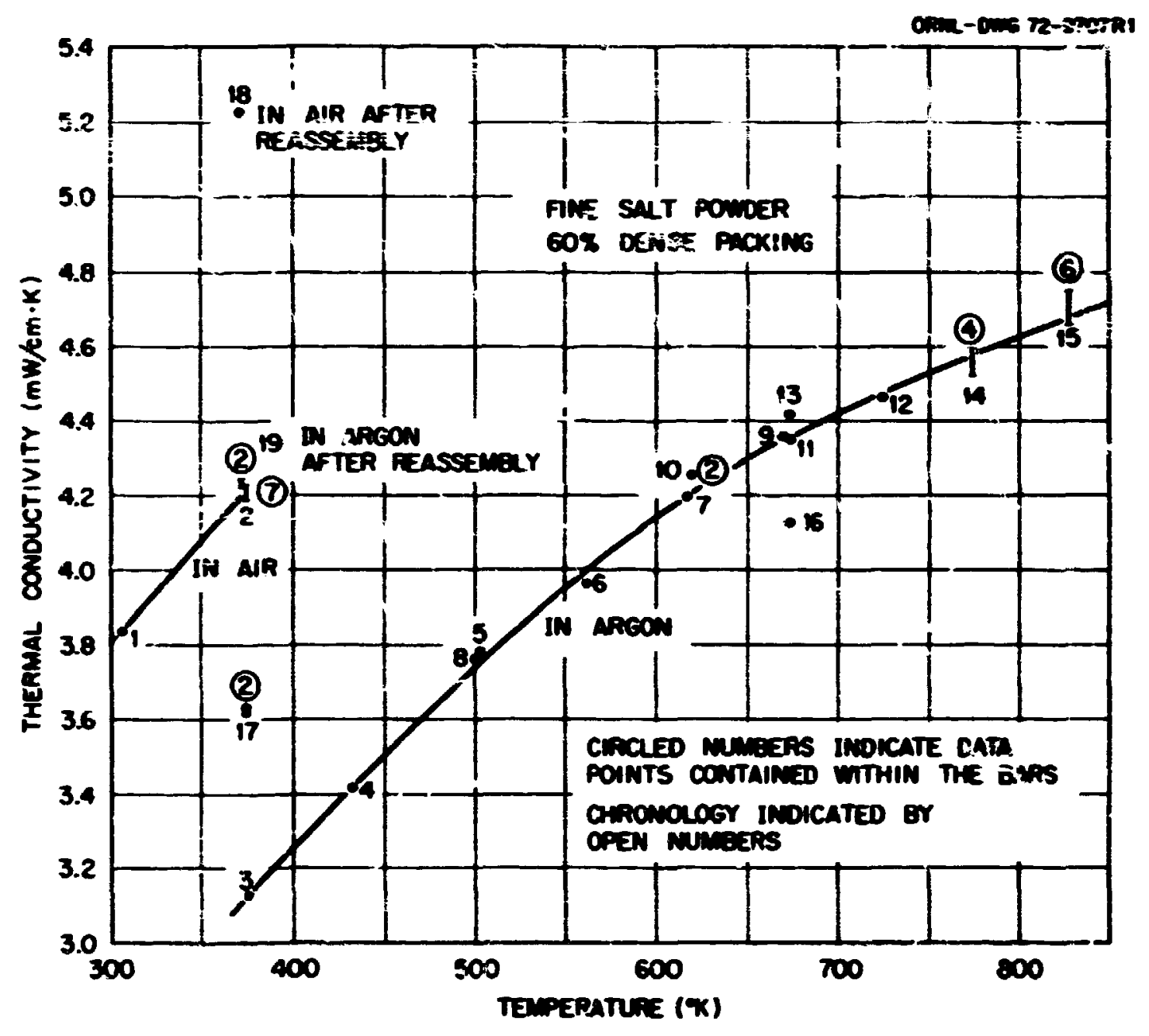

Fig. 3.10. Thermal Conductivity of "Pine" Salt Powder in Air and in Argon as a Function of Temperature. 
rearrangesents, etc. The lower temperature measuraments were made in an air atwosphere, while arson was used at temeratures above $380^{\circ} \mathrm{K}$. Multifle sets of data were usvally taken at eech temperature in crder to study and check the operation of the apparatus, and the land at each data temerature contains the indicated muber of individurl data points.

The thermal conductivity of the "fine" salt powder increase: regularly with temperature since the terperature coefficient is largely deternined by the gas phase. The dominance of the gas phase is lurther illustrated by the 25 decrease in conductivity wen argon is substituted for air. Jp to $620^{\circ} \mathrm{K}$, the results showed no hysteresis; however, irreversible bebavior wes observed at higher tesperatures. After exposure at the highest. temperature, the subsequent result at $570^{\circ} \mathrm{K}$ was slight] $\mathrm{l}$ lorer than the value obtained earlier, whereas the final valise obtained at $373^{\circ} \mathrm{K}$ wr siguificantly higher than the first.

The apparatus vas disassembled to the extent that the steel pouder container could be oently tapped in an atterpt to redistribute the porder within the container. Subsequent measuresents at $573^{\circ} \mathrm{K}$ in air and in argon were considerably higher than all carlier unes. On complete disassebly of the apparatus, we found that the salt pouder had wore or less agglomerated and hence would not pour out. The lops were very friable and easily broke to gire the original particles. We belleve that the explanation for the meesured differences in the value of $\lambda$ is the differences in thermit expansion for the steel can and the salt pewder. On cooling from the bighest temperature where the salt was plastic and free of strain, a gap was created at the outer radius of the salt anmulus. (f. steel core heater is located at the center of the saj.t). However, because of the partial sticking and cluping of the salt pourder, its $\lambda$ had increased sufficiently to overcone the added thenal resistance at the gap and thus resulted in the observation of a net increase in $\lambda$. The lifht tapping on the csn apparantly served only to filter soure fine particles down into the outer gap, which reduced the gap resistance. Wo effect on the luns of porder was noted. 
The powdei apparbtus w's modified several times during the measurements on the fine salt. Foilowing these measurements, the performance and characteristics of the porder radial hest flow appsratus were studied by using a well-characterized $\mathrm{M}_{\mathrm{g}} \mathrm{O}$ powder supplied by Godbee. 38 Godbee and Hoore 39 has freviously measured the $\lambda$ of this powder. Two basically different assemblies of the apparaius were made with the 40 poirder. The first one duplicated the s\%stem in which the reported fince salt values were obtained. $T$ : : second was ax improved version of the apparatus as suggested by carlier experiences. Comparison of the results for the two assemblies indicates that the first reäults for salt could have a temperature-dependent error, leading to a measured value about $9 ; 6$ toc high at room temperature and decreasing to zero error at about $600^{\circ} \mathrm{K}$. We feel that this is the maxim error that could be applied to the results for fine salt poider.

Figure 3.11 shows the results obtained in the improved apparatus on the "mediun" salt, trigether with a curve showing the "fine" walt rusults from Fig. 3.10 adjusted for the $9 \%$ erzor cited above. The thersa? conductivity of ihe "nediue" salt approximates that of the "fline," but is slightly lower at low teperatures and significantly higher at high temperatures. There are two plausible explanations for this behavior. First of all, we have ignored the fact that the "mediun" porder is much too large for the dinensions of the apporatus since cne of the objectives of this experiment was to determine if decrepstation of the salt by the inciuded brine would significantly decrease the thermel conductivity. Theoretically, the "flne" and "ieulian" powders should have essentially the sane $\lambda$, even though thes differ by a factor of about 5 in particle size. With respect to $\lambda$ considerations, powiers are not "fine" until their dimensions approach the ges mean free path. Therefore, we thin's that the jow $\lambda$ at $300^{\circ} \mathrm{K}$ is an effect due to the spparatus, and that the true value woula be the same as for the "fine" salt.

The grenter tempersture coerficient of $\lambda$ indt leads to higher $\lambda$ values for the "mediun" salt is likely the result of radiative heat transfer. Pidiative transfer would not be expacted in the "fine" sanple because of the muct greater muber of scattoring boundaries. However, as few as four grains may span the annulus in the "mediwn" simple; therefore, the sample is senitransparent. 


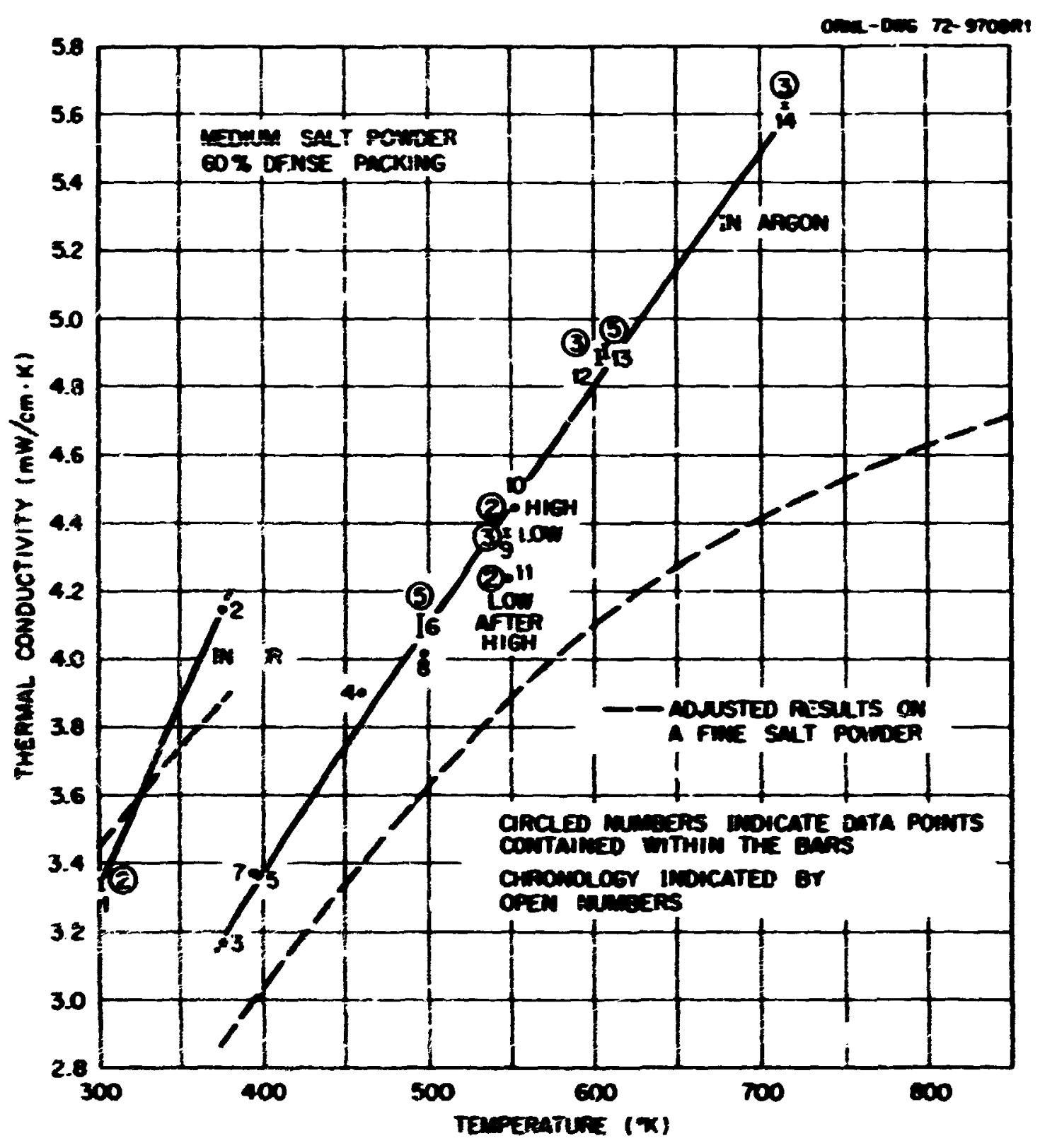

Pig. 3.11. Thermal Conductivity of "Mediun" Salt Ponder in Air and in Argon Purction of Texperature. The results for "fine" sait are those from Fig. 3.10, adjusted for the error discussed in the text. 
In general, the results for the "medium" salt follow the pattern of the "fire" salt; that is, up to $600^{\circ} \mathrm{K}$, there is no obvious hysteresis or any apparent change because of decrepitation. (if decrepitation has occurred). Under the very slow heating conditions of the radial apparatus and the temperature gradients, it is possible that the brine inclusions could diffuse harmlessly to boindaries rather than explode the grain. Postexperimental examination of the salt particles and a screen analysis should provide such information about the brine.

The three data points at $550^{\circ} \mathrm{K}$ in $\mathrm{FIg} .3 .17$ shor an interesting effect that is attributable to the discrepancy in thermal expansion cited earlier. The data narked "10," was obtained with a $2.5^{\circ} \mathrm{C}$ radial teperature drop across the salt, wile the "high" had a $16.3^{\circ} \mathrm{C}$ drop. (The salt annulus is $2.2 \mathrm{~cm}$ thick). The increase in $\lambda$ for the "high" was coused by the increased mechanical pressure from saple expansion. The marted drop in the "low after high" shors that the behavior of the poider is irreversible, probably because of plestic deformation.

An extension of this powder experinent is the application of the finite-difference heat conduction progran HirMTG $3^{40}$ to our particular geometries. This computer progran is being used extensively obr the thernal analjsis task as reported in sect. 3.3 of this report. We have used HBATIG 3 to thoroughly analyze the severul powier radial devices eployed in our laboratory, particularly that of Noore 39 and the ones developed subsequentiy. The progran has verified our concerns about these devices and has pointed out some serlows extrancous beat flow in tine earlier powder radial apparctus. Of equal inportance is the observation that: FRATI.G3 calculations are substantiated by our laboratory neasurements.

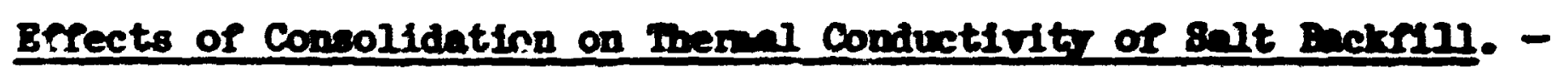
The powier surrounding a can containing nuclear waste will be subfected ts both elevated temperature and compressive stress, and wo ultimately be restructured. There is a factor of 10 or nore change in therinl comductivity fron the powcer stare to the restructured state, and this will cause a significant change in the terperature of the mote end its surroundings. our results for salt ponder in the proviow section bave show 
that measurable changes are otserved even for very low stress levels. We are designing an experiment to measure directly the thermal conductivity of salt powder, as a function of time, temperature, and compressive stress, to the point that the sample is restructured to solid salt above $90 \%$ of theoretical density.

Waste-Hole-Backfill Simulation. - An instrumented probe made of $1 / 2-$ 1n. -OD by 4-in.-10ng 304 stainless steel tube rith an interral heater and therwocouple and an outer velded-on thermocouple was used to simulate a waste container in an experiment designed to assess the early transient state of inste kurial. A large block of solid salt with a 1-in.-diam; 6-in.-deep hole, and two thermocouple boles with raisi of $11 / 16$ in. and 1-5/8 in., respectively, was used to represent the mine floor.

The probe was suspended directly over the block and was heated at constant power in still air to a surface temperature of about, $500^{\circ} \mathrm{C}$. When equilibriu was obtained, the powered probe was dropped into the hole and a co puter-operated data acquisition systen ${ }^{41}$ monitored the response of the four thermocouples with time. Four different experiments were conducted with the probe. In the first experiment, the anrulus between the probe and the salt was left expty. In the second, fine salt powder was poured into the bole $20 \mathrm{~min}$ after the probe was inserted. In the third, fine salt powder was poured in imediately.

The fourth experiment involved a different concept of backfilling that recuires explanation. We an envision severai potential problems in the use of salt powier as backfill. First, there is the matter of the very Iow thermal conductivity of salt powder. Also, the presence of powder might make retrieval by overcoring nore difficult since a large core would have to be taken to ensure a solid salt outer surface. In addition, the salt powder would offer no resistance to the inconing brine. In light of this, we considered that sons type of solid backfill might be desirable. A cenent-type would not be feasible since the temperatures are excessive for a vater-base cement. A likely candilate, -60 wt of $\mathrm{CaCl}_{2}-40$ wt of $\mathrm{KaCl}$, was discovered $:$ n the $\mathrm{BCl}-\mathrm{CaCl}_{2}$ binary system. The nelt, which has a eutectic at $500^{\circ} \mathrm{C}$, is very fluid, is easy to prepare from cheap and available waterials (especially the (racl), should hare a high tiernal conductivity, would be free 
or brine, and would rigidly encase the waste cylinder. Accorlingly, for the fourth experiment, we prepared a crucible of meit of this cumpusition at just over $500^{\circ} \mathrm{C}$ and poured it into the annulus immediately after the frcbe was inserted.

The results in Fig. 3.12 indicate that the can and the surrounding salt biock experience very different temperature conditions before quasisteady state is reached. It is sbvious that the powder must be poured in very quickly in order to minimize the temperature rise of the waste container. However, the results for the molten eutectic experiment are of the greatesi interest. The surface temperature of the can increased momentarily by about $70^{\circ} \mathrm{C}$ wile the melt was freezing. Once frozen, the eutectic displayed its high conductivity in reducing the temperature of the can approximately 60 to $70^{\circ} \mathrm{C}$ below that achieved with the powder, a significant drop with respect to corrcsion rates and other effects.

\section{Development of an Automatic, Constant-Temperature Ice Bath. - There} are numerous applications in the laboratory where constant-temperature ice baths are used. One of these, called the "longitudinal heat flow apparatus," utilizes a ice bath requiring constant replenishent of the ice. Over weekends, control is lost and considerable time is needed to reestarlish steady state. The transient plane probe is also a device requiring a stable reference temperature. A completely automatic bath, such as that reported in the literature, 4 ? is highly desirable.

During the past year a quarter-ton-capacity automatic ice bath was designed according to the literature, but with some modificaticns. Basically the unit consists of a 3/8-in.-OD copper refrigeration coil immersed in a stirred water bath. A constant-pressure expension valve admits $R-1 E$ refrigerant from a mechanical refrigeration unit so that the coil is maintained at about $30^{\circ} \mathrm{F}$. At this temperature, an ice aeposit about 1 in. in diameter will be maintained on the coil.

Bxcess refrigerant overflows into a secondary evaporator, consisting of a SCR-controlled 1200-W heater clamped to a 10-3/4-in.-dian copper disk that is equipped with a spiral groove and cover to guide the R-12 as it is transformed from liquid to vapor. The original design reported 


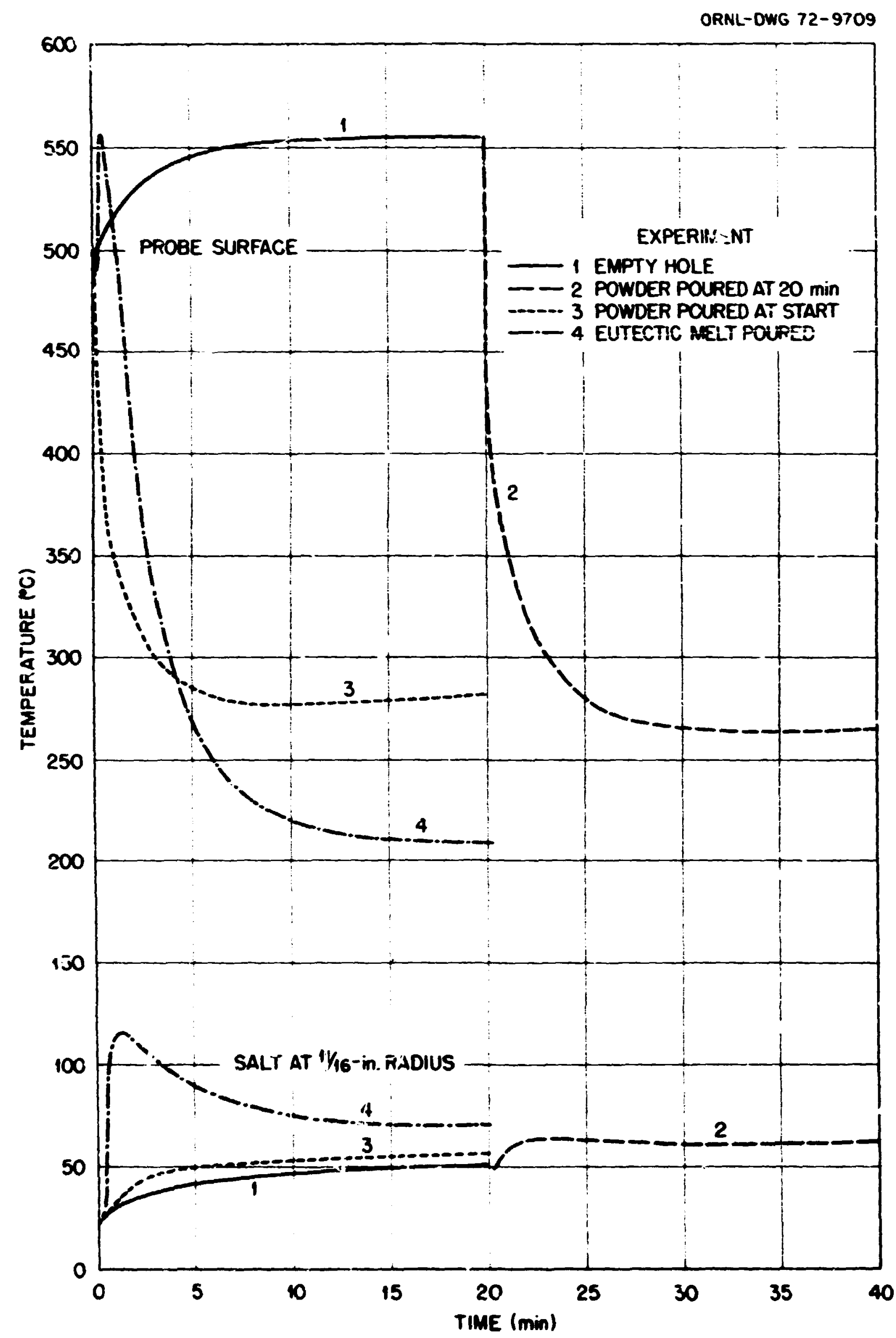

Fig. 3.12. Temperature Response with Time of the Probe Surface and the Solid Salt for FC"r Experiments Simulating a Waste Can in a Hole in Solid State. The probe center line temperature (not shown) was about $50^{\circ} \mathrm{C}$ righer than the surface temperature, and its resporse lagged slightly in time. 
in the literature works well but involves a coil immersed in a stirred tank of heated antifreeze; such a design is slightly less convenient for a compact, portable unit. 


\subsection{Thermal Analyses}
R. D. Cheverion
h. D. Turner

The high-level waste repository thermal analysis discussed in the previous annual report 43 was, to a large extent, limited to establishing calculational methods and technical feasibility. Since that time, parametric studies have been conducted with room and pillar width, waste container array and spacing, waste age and composition, and stratigraphic detail as variables. Preceding this effort, thermal conductivity temperature dependence was included in the three-dimensional heat-conduction code, and criteria associated with limiting temperatures were modified to achieve greater consistency. A topical report that discusses most of this work in detail ${ }^{8}$ has been written. The changes in the criteria and results from a few preliminary calculations were included in the previous annual report. 43

Verification of the accuracy of the mathematical techniques and models used in this work is under way, both at the University of Kansas and at ORRL.

\subsubsection{Thermal Conductivity Temperature Dependence}

The ORNL ADI (alternating direction impicit) code was modified to include the temperature dependence of thermal conductivity. It is now possible to recalculate the conductivity at each node for specified time intervais tiiat consist of one or more time steps. The conductivity used for the time interval, $t_{m+1}-t_{m}$, is evalnated at the temperature,

$$
T_{n}+\left(\frac{T_{n}-T_{n-1}}{t_{n}-t_{n-1}}\right)\left(\frac{t_{m+1}-t_{m}}{2}\right),
$$

where

$T_{n}$ is the last calculated temperature,

$T_{n}-T_{n-1}$ is the temperature change during the last time step,

$t_{n}-t_{n-1}$ is the last ifme step,

$t_{m+1}-t_{m}$ is the next time interval, which can consist of one or

$t_{m}=t_{n}$ 
Suificient accuracy has been achieved in the calculations by considering only the effect of temperature on the thermal conductivity of salt, and by reevaluating the conductivity for time intervals consisting of ten time steps.

\subsubsection{Parametric Analysis for 1000-ft Depth}

Models. - A tyoical 3-D(XYZ) model describing the general burial scheme and the stratigraphy at the iyons site is shown in Fig. 3.13. Room, pillar, and container array combinations considered in most of the parametric studies are as follows:

(1) 15-ft room; 25-ft pillar; single row of containers

(2) 18-ft roam; 30.ft pillar; single row of containers

(3) 30-ft room; 30-ft pillar; double row of containers

(4) 50-ft room; 50-ft pilla:; double row of containers

Calculations were also made with multiple rows of containers in the 15-ft rocm and with more than two rows in the 30- and 50-ft rocens. In each case, the container was 6 in. in diameter and $10 \mathrm{ft}$ long.

The pillar widtins given above are tentatively considered to be minimow permissible values for a mine depth of $1000 \mathrm{ft}$. The minimum permissible room width is now assumed to be $18 \mathrm{ft}$ (15 ft piceviously), and the maximum is assuriad to be $50 \mathrm{ft}$.

Variables. - Vuriables considered ir. the parametric analjsis were roow--pillar width combinations, distance between containers neasured alorig the length of the room (pitch), container arrays, and waste age. Waste ages of $1,4,10$, and 20 years, and pitches of from effectively 0 to $50 \mathrm{ft}$, were included.

Waste Characteristics. - The high-level waste considered in the parasetric studies was the typical LiR waste described previcus 15.43 Variations in the isotopic couposition of the wastes were nade for sone calculations by increasing the ratio of actinides to fissicn products. The "typical" ratio of actinide to fission-product power at 10 years after reprocessing was 0.064 . Other ratios included in the studies were 2,10 , and o times this value. 


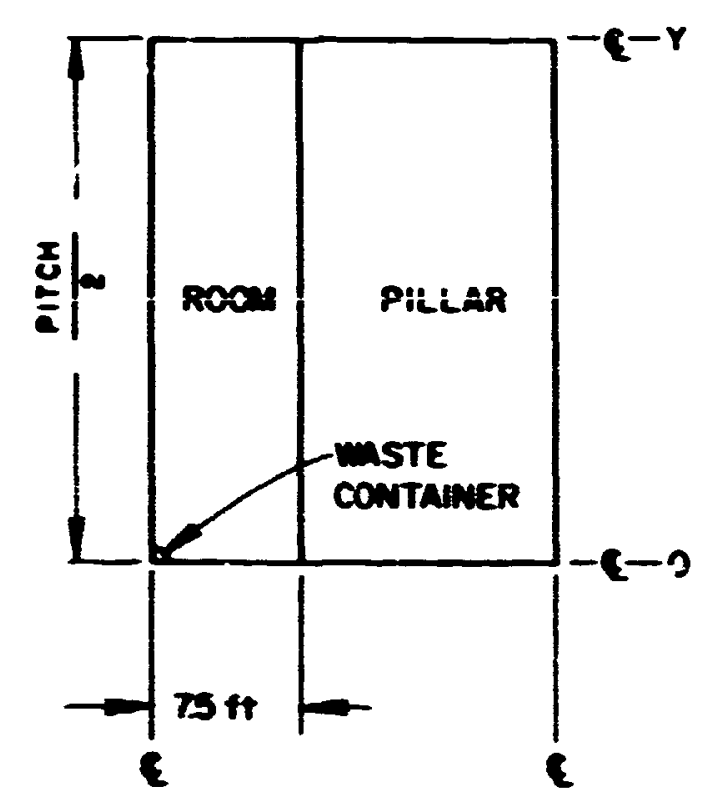

HORIzONTML cROSS SEction of UNT EEL
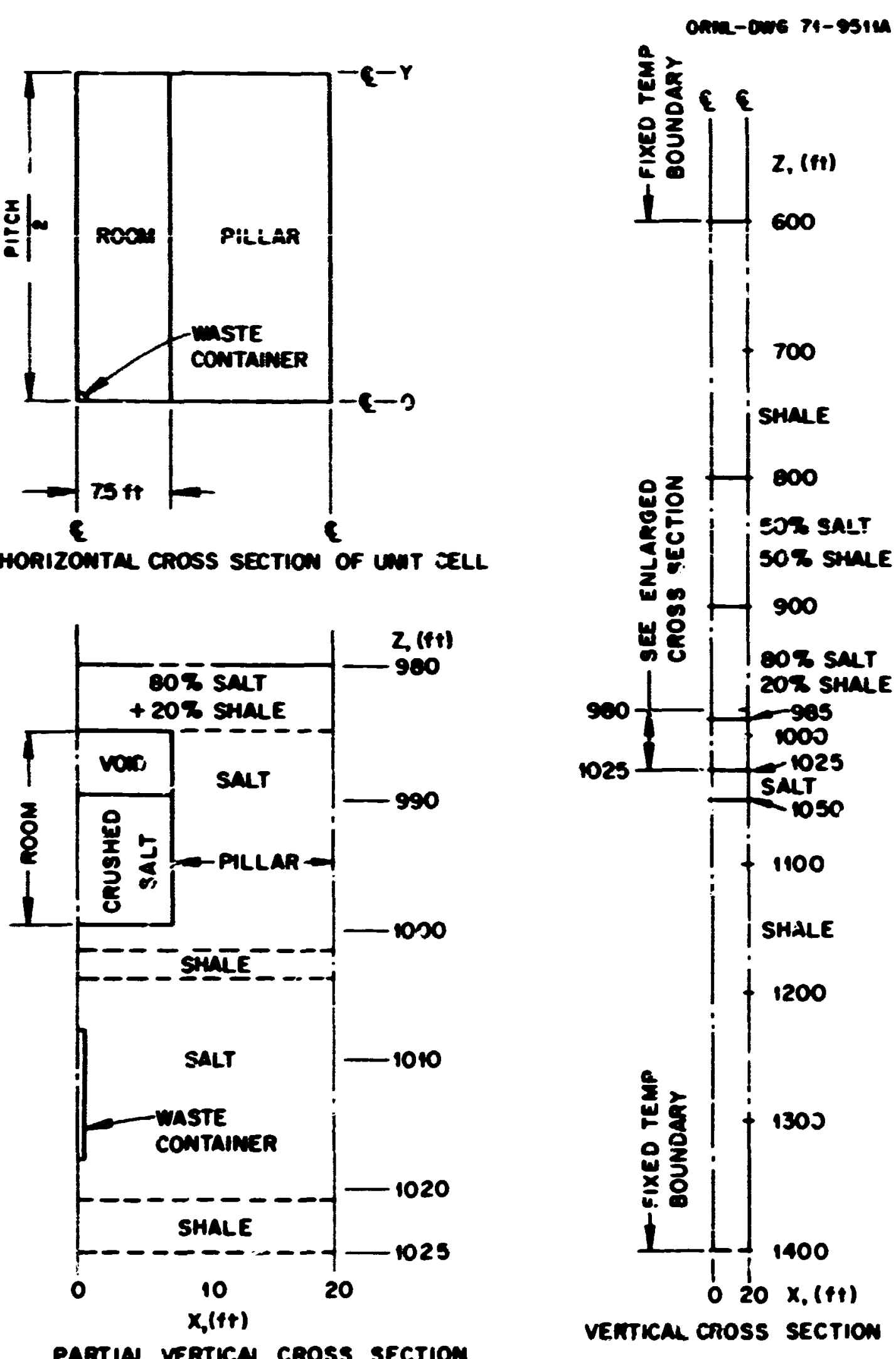

Fig. 3.13. Three-Dimensional Model of a Unit Cell of the High-Lerel une: 15-ft Room. 
Claddius inulls considered in a few calculations were also typical for LWRs. The cladding material was Zircaioy, and the hulls were assumed to be contamirated with $0.1 \%$ of the high-level raste.

Results of Analysis. - Results from the parametric analysis are reported as the maximum perrissible gross and net loading surface densities, loading per container, and power per container as a finction of pitch, waste age, and rocm size. int area refers to the burial room floor area, and gross area refers to this latter area plus the pillar cross-sectional area. Fsumissible values are consistent with limitations imposed by the salt and waste temperature criteria.

Figure 3.14 shows zross loading surface densities for 10-year-old waste, corresponding to the salt and waste criteria. These criteria stipulate that, in the 10-ft-thick horizontal layer of salt in which the waste cylinders are buried, no more than $1 \%$ of the salt will be aliowed to have a temperature in excess of $250^{\circ} \mathrm{C}$ and no more than $25 \%$ of the salt will be allowed to have a temperature in excess of $200^{\circ} \mathrm{C}$. The minimum envelope of these curves, the trends of wich are typical for all waste ages considered, constitutes the maximum permissible surface density. The right-hand portion of this envelope can be changed significantly by assuming different waste properties. The waste considered in the calculations has a relatively low thermal conductivity and maximim permissible temperature $\left(\mathrm{k}=0.25 \mathrm{Btu} / \mathrm{hr} \cdot \mathrm{ft} \cdot{ }^{\circ} \mathrm{F}\right.$; maximum temperature, $\left.1100^{\circ} \mathrm{F}\right)$. Increasing either of these values moves the waste portion of the curve to the right.

Complete sets of curves for 1-, 4-, and IC-year-old wastes are preseited in Figs. 3.15, 3.16, ard 3.17, respectively. These results indicate thit, for a particular waste age, the difference between maximum permissible gross surface densities for the three rocm sizes is small. However, there are significant differences between net surface densities. For instance, in the case of a 10-year-old waste, the maximum permissible net surface density for a 15-ft room is aboat $37 \%$ greater than that for the 30-and 50-ft rocms. This constitutes a substantial saving in mining and salt disposal costs for the 15-ft rocn. 


\section{4}

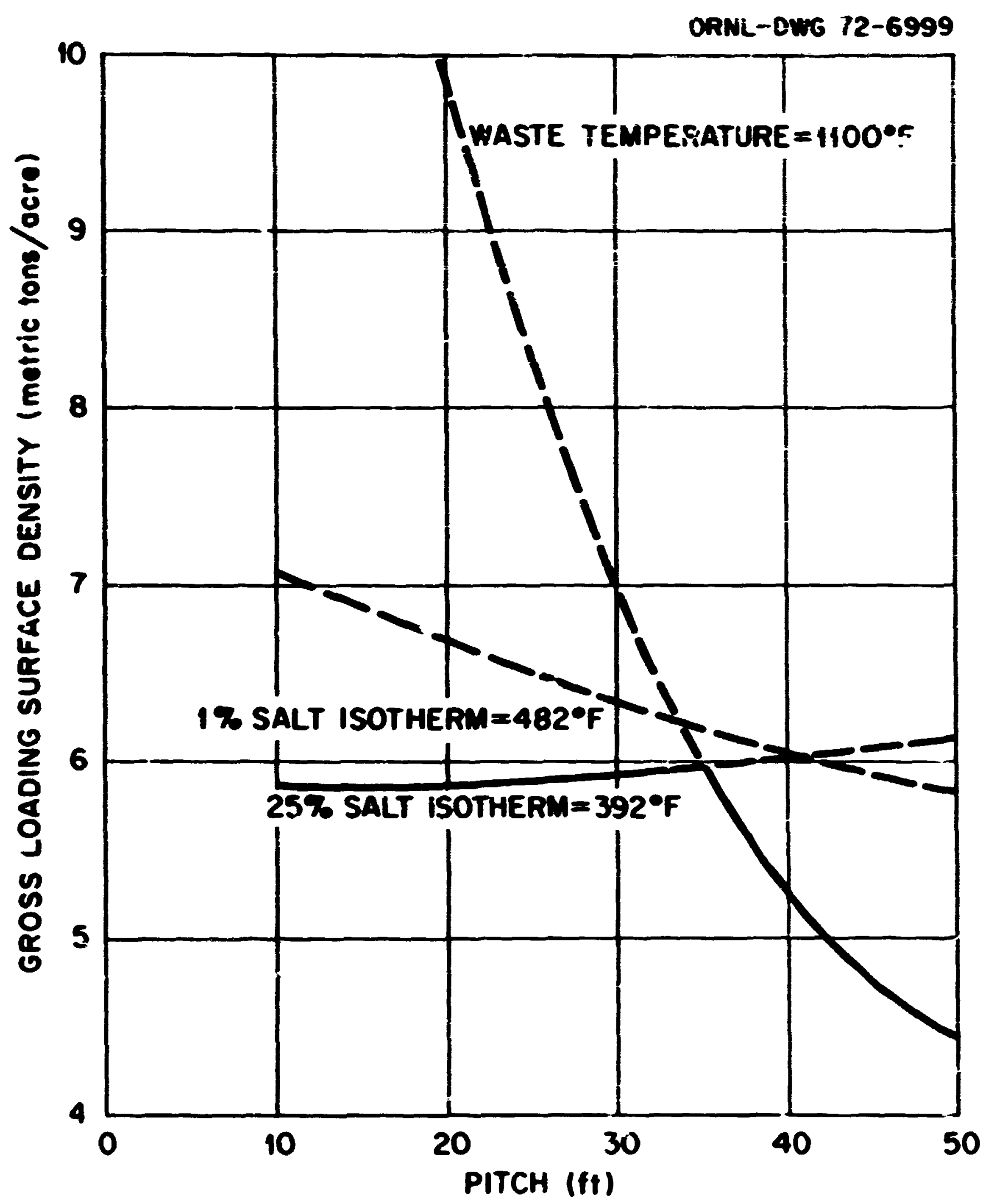

Pig. 3.14. Gross Loading Surface Density for 10-year-old Waste in a 15-ft Rocin in the High-Level Rerository. 

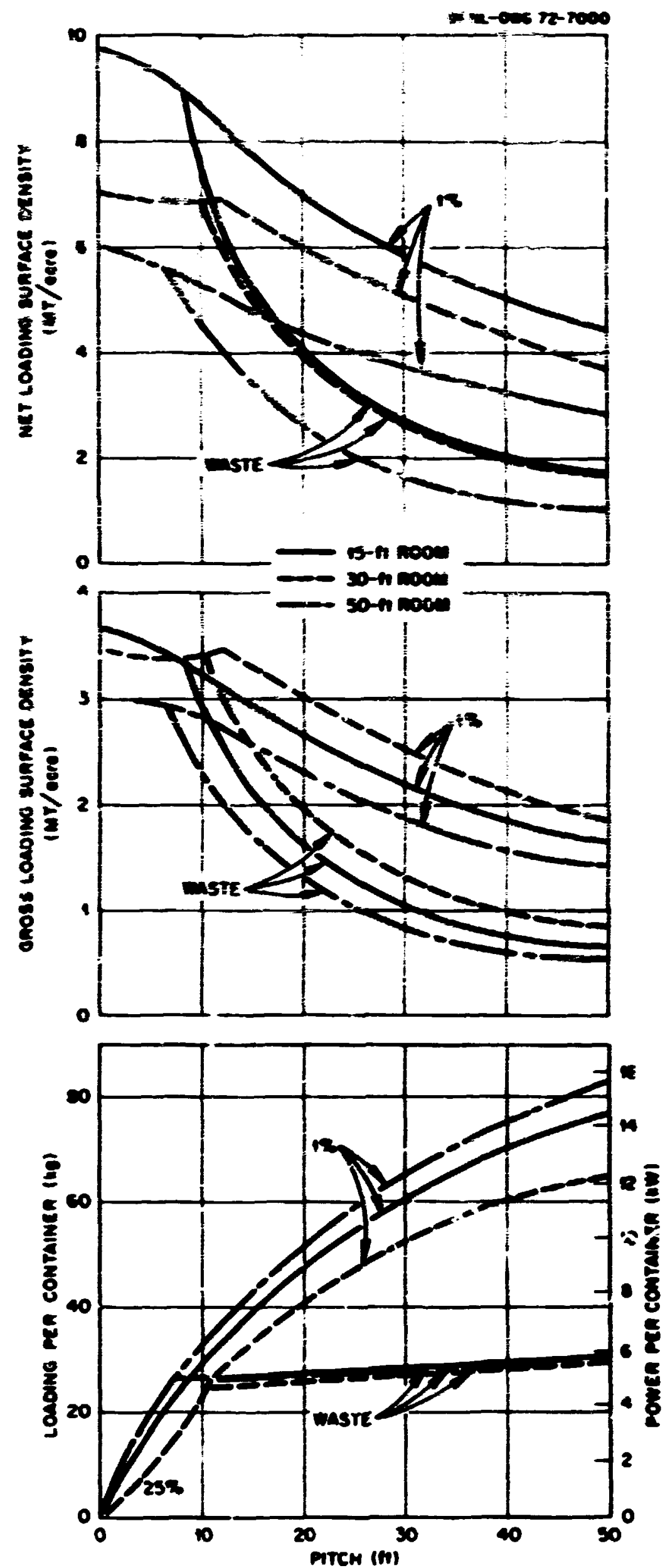

Fig. 3.15. Cosparison of Hion-Ievel Repository Ioading Burface Densities and Loadings per Waste Package for 1-year-cild Waste and 15-, 30, and 50-ftwide Rooms. 

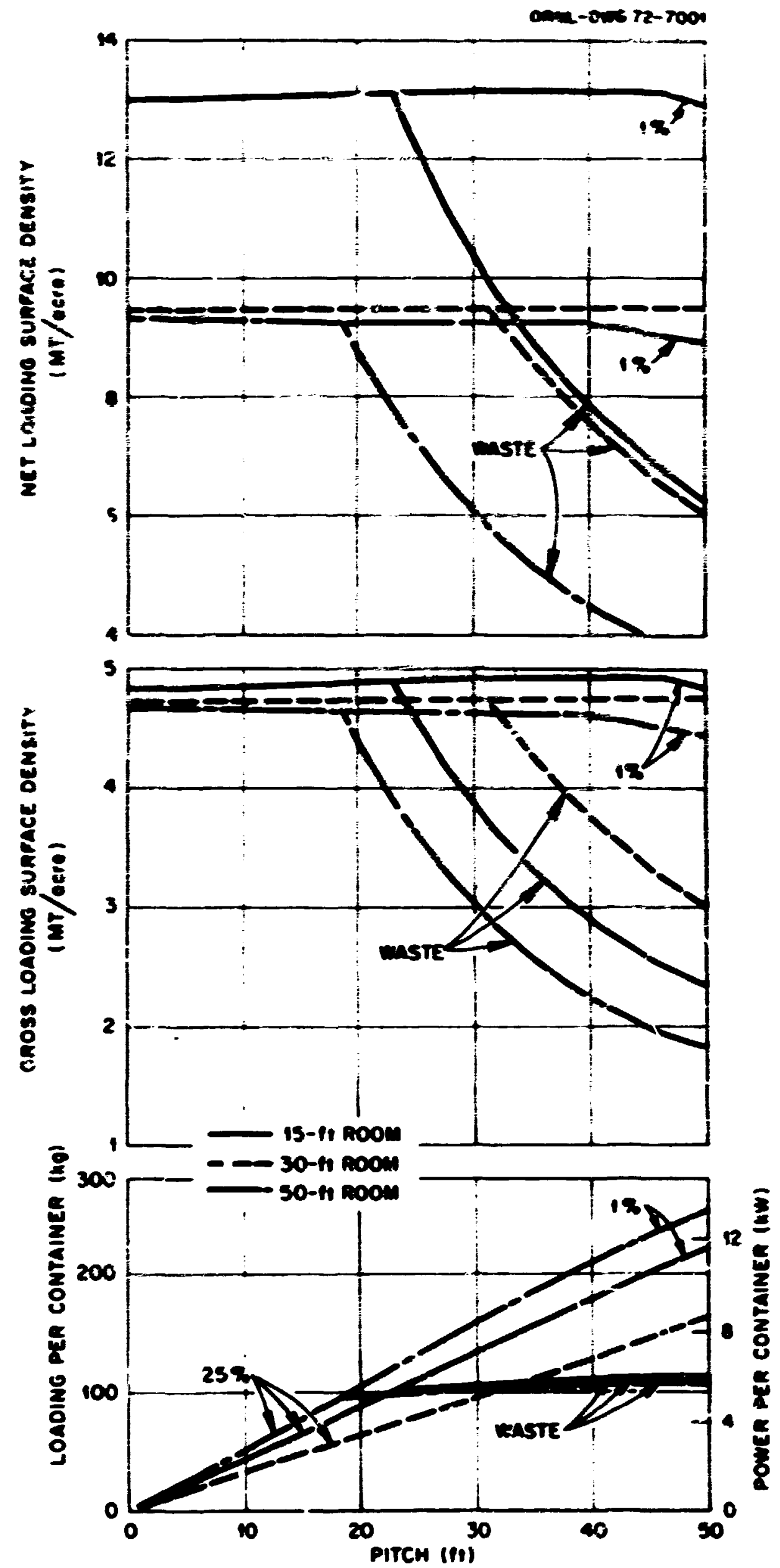

Fig. 3.16. Comparison of High-ievel Repository Loeding Surface Dersities and Loadings per Waste Package for 4-year-01t Waste anc. 15-, 3n-, and 50-ftwide Rcoms. 

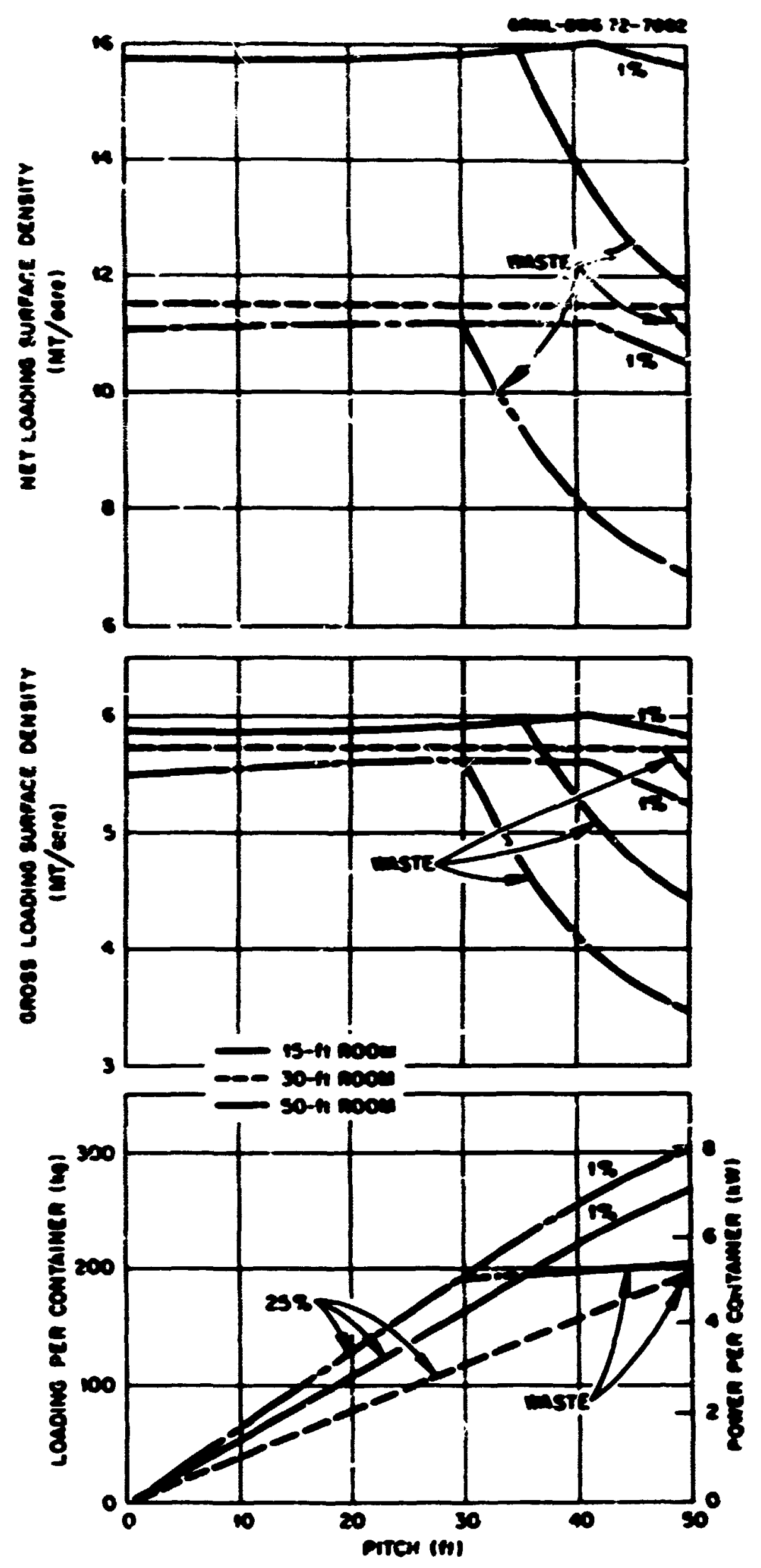

F18. 3.17. Comperison of High-Level Repository Loading Burface Dansitiea an. Ioadings per laste Package for 10-sear-0Id laste and 15-, 30-, and 50-Itwien Roces. 
It is also observed wnat the younger the raste, the smaller the pitch (and bence the loading per container) for wich the 1.6 salt and the wasie criteria becone liniting. This tends to provide incentive for inproring the thereal characteristics of the younger wastes. Hovever, handling and transporting considerations noy lint the power per container, irrespective of vaste age, to about $5 \mathrm{~kW}$. In this case the relatively poor theral condectivity and $20 \mathrm{~N}$ illowable vaste teperature considered in the analysis du not ipose a serions restriction. On the other hand, it lifht be desirable to iprove cn-site handling and transport capabilities, along with vaste characteristics, io pernit greater loadings per container.

Based on the paranetric analrsis and previous econonic studies 44 of interin storage aboveground, solidification, anc transportation, it iras tentatively concluded that a waste age of 10 years and the 15 -ít-room, 25-rt-pillar combination would be the nost econonical.

Since the ninima witbs for a roo has been increased to $18 \mathrm{ft}$ for ease of access, a fer calculations vere also wade for an 18-ft-rocm, 30-ftpillar combination with 10-year-old waste. The results indicate that the anion pernissible gross loadin- surface densities were the same as those for the 15-ft-roon, 25-ft-pillar combination.

Tenperature histories for several points of interest in the repository are show in Fig. 3.18 for 10-year-old waste in a 15-ft-room containing a 25-It pillar. The locations of the particular points are identifled alphabetically in Fig. 3.19. It is observed that the center line of the waste (curve a) and the container surface temperature (curve b) peak in about 5 and 15 years at 900 and $550^{\circ} \mathrm{F}$, respectively. lear the base of the pillar, the maximum temperature rise (curve d) is $300^{\circ} \mathrm{F}$ and the corresponding time is 50 years. The maximum temperature rise at the base of the protective shale layax (curve B) is $170^{\circ} \mathrm{F}$ ( 130 years); in a stagnant fresh-water agulfer at $300 \mathrm{ft}$ below the surface (curve $\mathrm{f}$ ), it is $37^{\circ} \mathrm{F}$ ( 500 years); and at the earth's surface (curve $e$ ), it is $0.26^{\circ} P$ (500 years). It is also observed that a temperature rise of only $1^{\circ} \mathrm{F}$ in the geologic formations surrounding the repository occurs $2500 \mathrm{ft}$ beyond the edge of the mined area (well within the AEC-controlled buffer zone) and about 2000 it below the earth's surface. The corresponding time is 6000 years. 


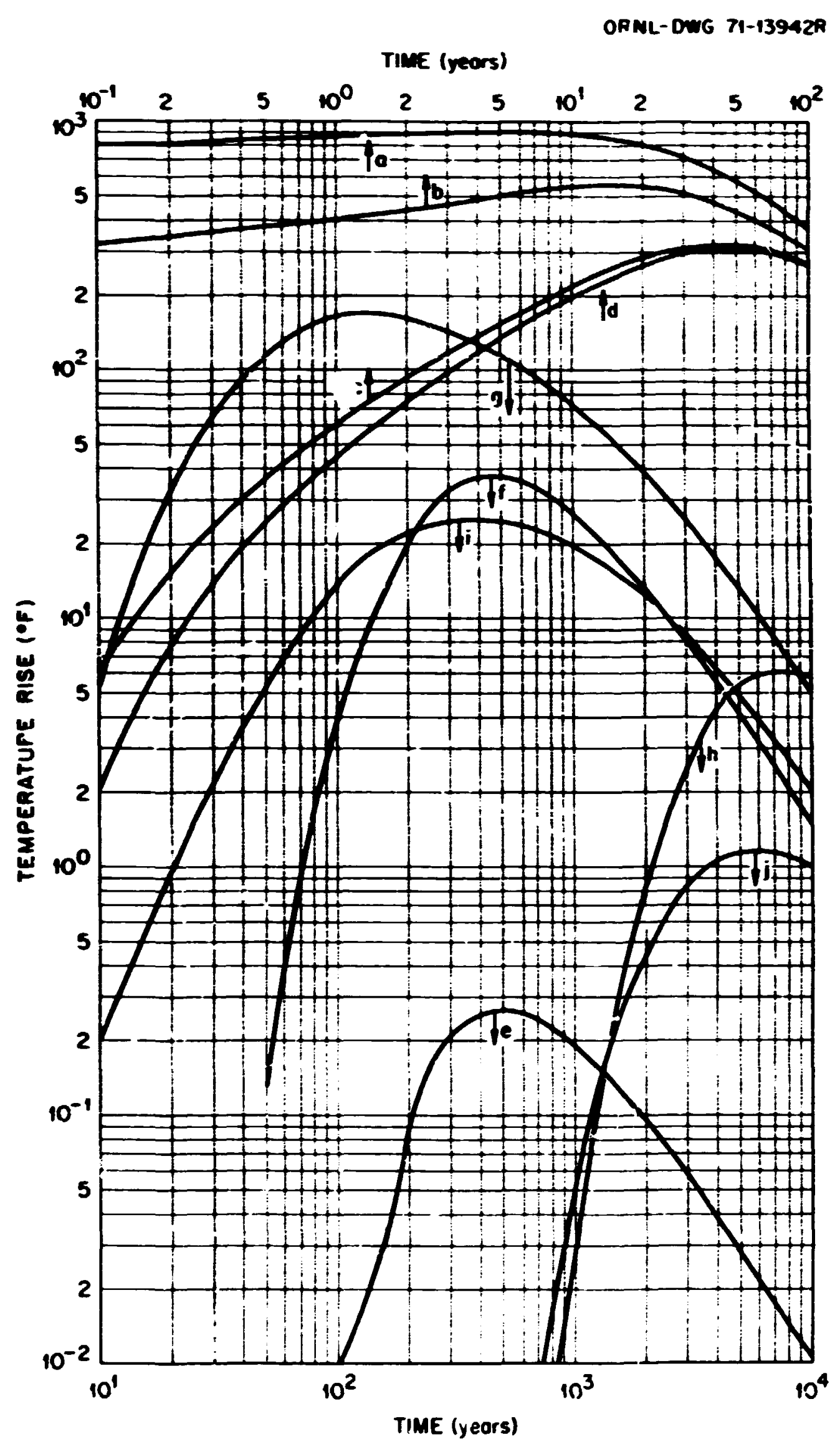

Fig. 3.18. Temperature Rise vs Time After Burial for 10-year-old LWR Calcined Waste, 15-ft Rocm, 25-ft Pillar, and Single Row of 6-in.-diam Containers on 30-ft PItch, Each Containing $165 \mathrm{~kg}$ of waste Nuclides. Curves are for points alphabetically identified in Fig. 3.19. 


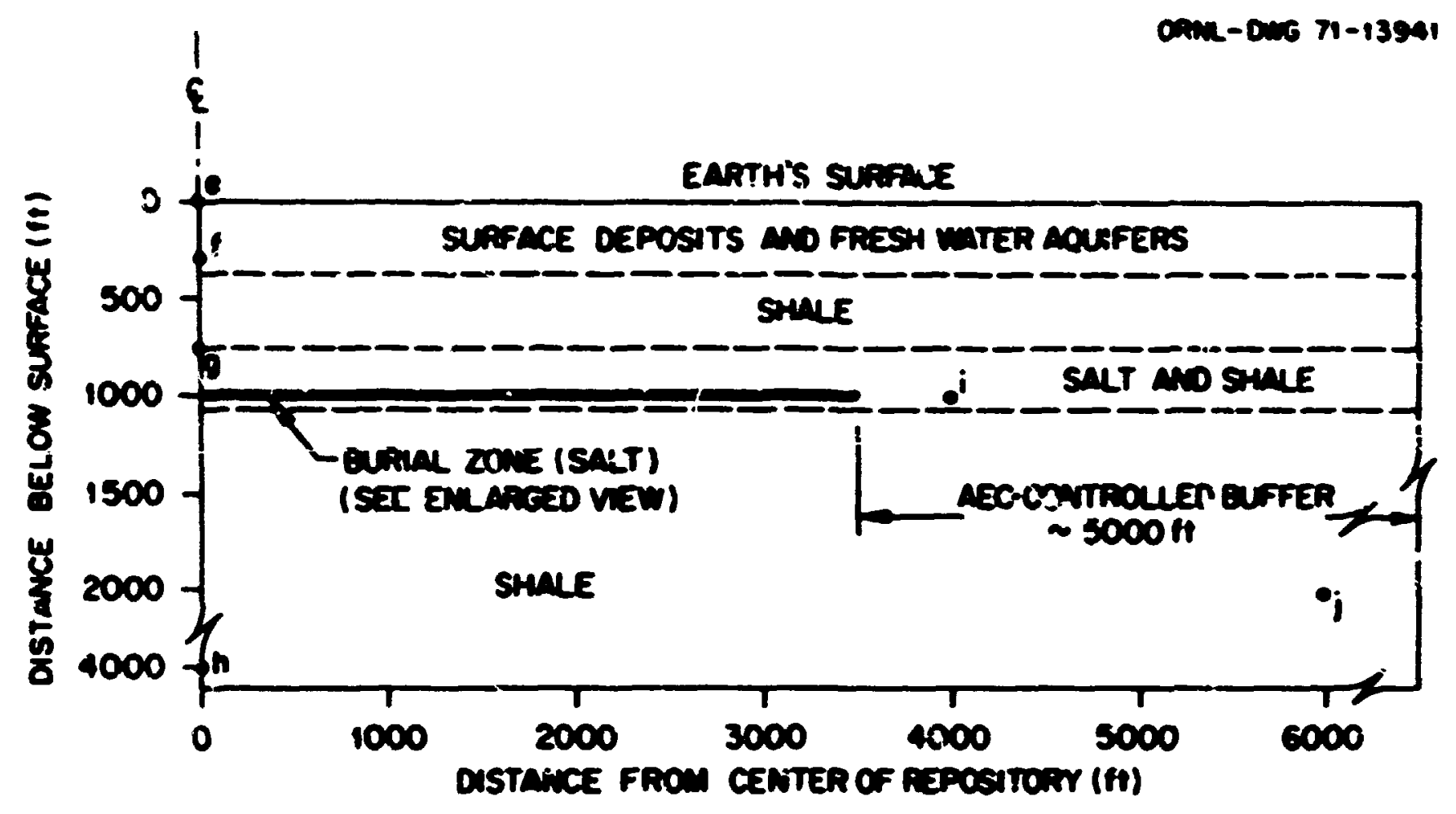

VERTICAL choss SECTION OF sapostiony
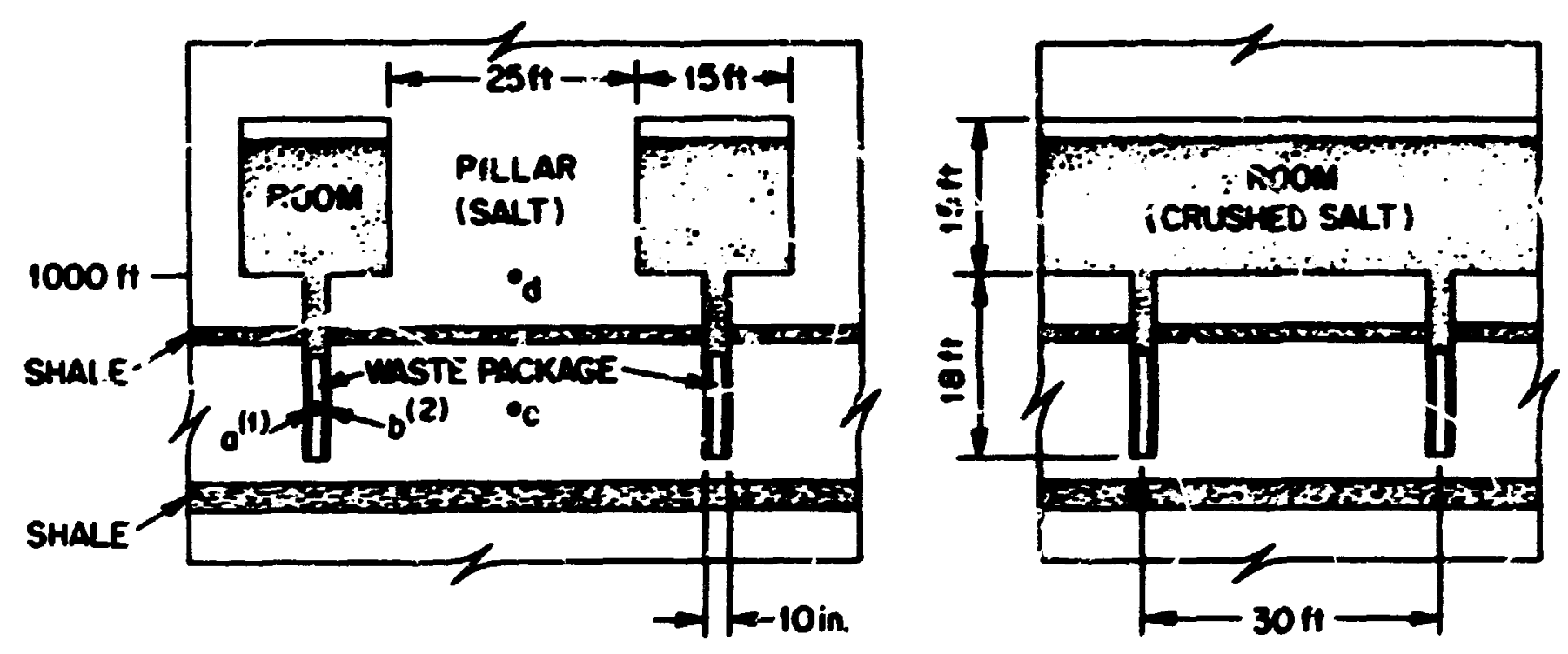

i. O: CEITER :INE

2. b: SURFACE OF COMTANER

ENO VEW OF BUAML ZONE FOR HIEH-LEVEL WASTE

SIDE VEW of DARM zOnE FOR HICH-LEVI MSTE

Fig. 3.19. Simplified Cross-Section Diagram of Waste Repository. 


\subsubsection{Other Considerations}

Phasing. - A phasing effect in temperatures exists because terparatures at all points first incresse and then decrease. Peak tenperatures can be increased or decreased ky changing the sequencing of burlal for a given burial array. In the parsoticic analysis, it was assuad that all waste was buried simultanecusly; in reality, bowever, it is burled contimously over a finite period of tine. $h$ 2-D(BZ), single-container, superposition nodel vas used to investigate the manitude of phasing relative to results obtained with the simlteneous-loading notel. Dader the "worst possible" conditions, the actual peak tenperatures on the sirface of a coutainer could be creater by about $240^{\circ} \mathrm{F}$. Bowever, the increase vas only $40^{\circ} \mathrm{F}$ for a leas extrene loading sequence, and the differmes is

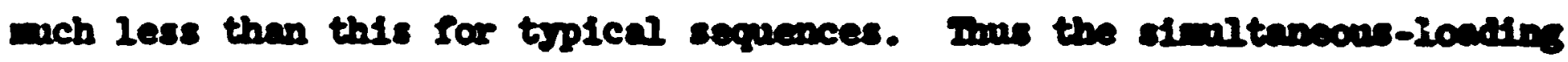
oxdel, vhich requires wach less coputer tins, is quith satisfactory for nost problem.

Coutalnar Diacster. - Most of the culculations bave ban nde by considering a 6-in. He container. Anticipated wate doneities are wah than dismeters of 10 to $i 2$ in. will be required for 5 kit of 10-swar-ald vaste. For a given woste thermi power level, increaster the contaliner

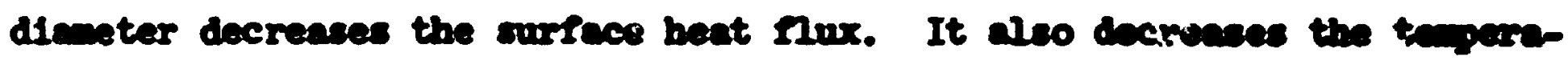

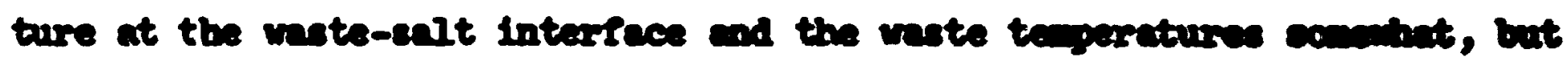

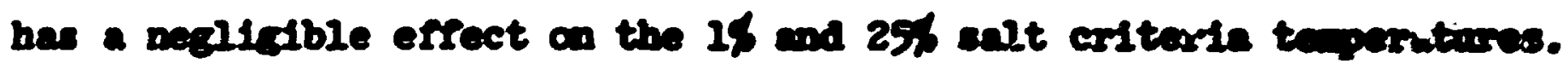

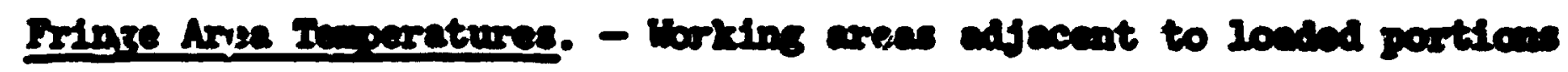

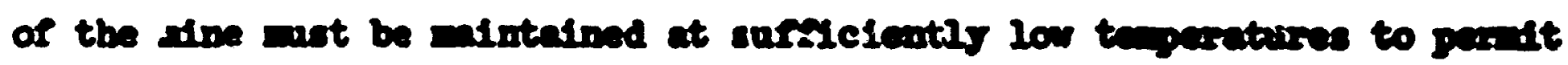
safe operation of the repository. Inase fringe areas include the conrieves,

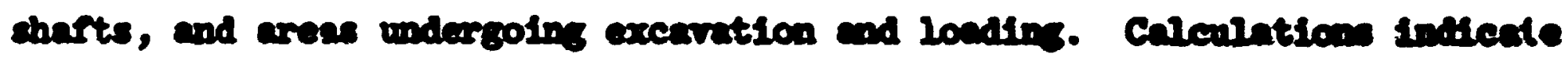

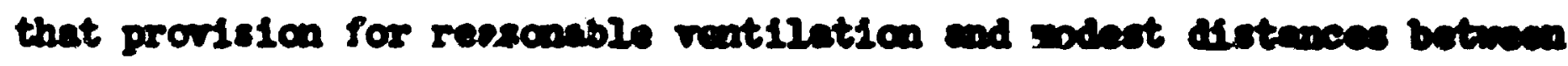

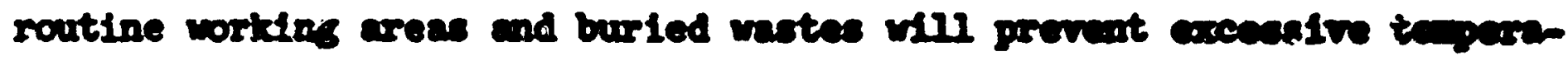
tures in those areas.

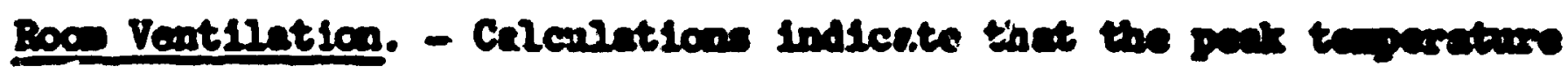

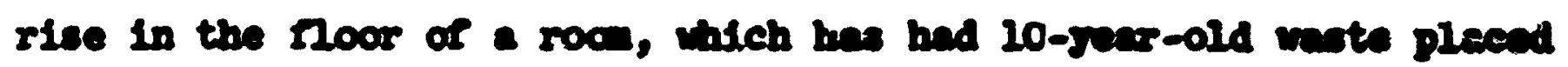
benath 1t, w1l ocew 5 jexre after burinl and will be only $20^{\circ} 2$ is the

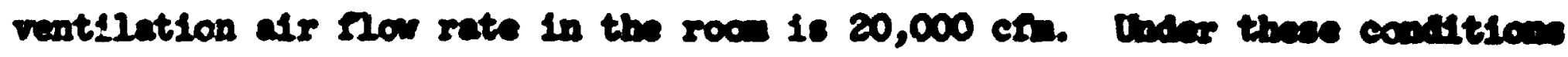


the pesk heat renoral rate by the air is $55 \mathrm{kH}$ per ft of roon length, which is about 40,5 of the beat generated. The corresponding temgerature rise in the air is $5^{\circ} \mathrm{P}$.

Salt michness. - The thichness of the salt bed at sane of the alternative repository sites is signiflcantly different fron that at lvoss. The prinary concern is over thimner bed that expose the overlying protective shale to higher temperatures. Calculations indscate that seducing the thickness of salt between the shale sad waste fron 250 it to $150 \mathrm{ft}$ increasen the eait-shale interface tenperature $50^{\circ} \mathrm{F}$. demperative changes at the maste borlizon vere negligible.

sotinide Concentration. - In rears arter raprocessing, the typical hifh-level waste considered in wort of these studies would hare an actinide-to-fleston product power ratio of 0.064. For a fer calculations, this ratio wa incressed to $0.128,0.640$, and 0 . Daults Indscate cssentially no difference in peit temparatures at the vaste borl20n, escuning

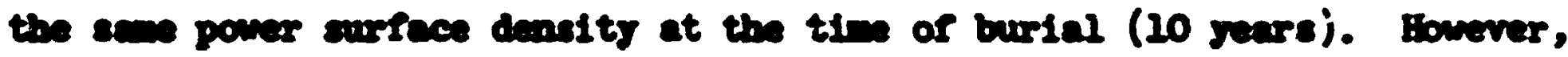
In the aquifer at a dopth of $300 \mathrm{It}$, and at the edge of the 1-adle NXC buffer sone, the pein terperatures slightly exceeded specified maxin in the cese of 100,4 ectintals.

Gadif Buls. - Caloulations ware ade for Zircalos cladding bulls that ware burled 1 ad 3 serre after reprocessing. Frare is little change In the effective bale-1ife over this period of time; thas the perniseible

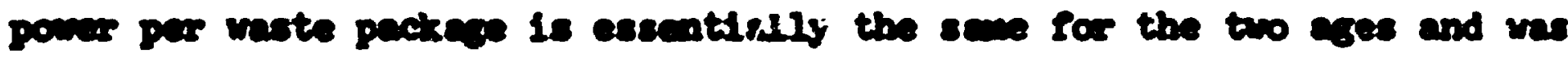

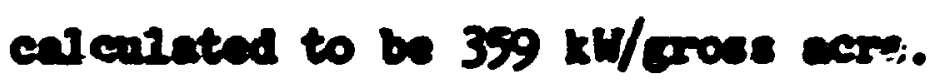

Twe expected power tron 1-sver-old claddips bulls 18 about $95 \mathrm{~W} /$ metric

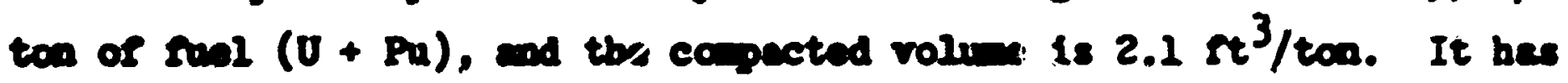

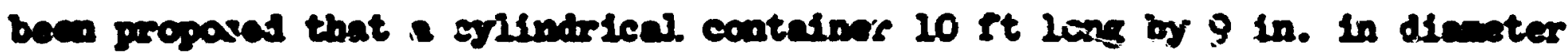

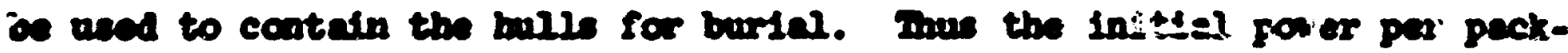

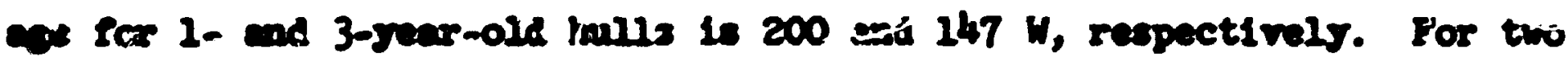
row of waste pecteres in a 15-It rocn, the pitches correopording to these:

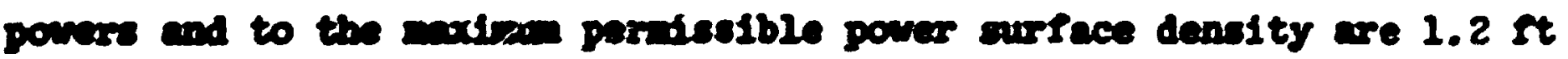
and 0.9 It, renpoctivily. 
According to ref. 45, shielding curing burial operations vill require sbout 3 It between boles in the noor for the 1-jear-ald bulls. Irus, burial in a 15-It roon will not be very efficient. whe use of mitiple rows in a larger roon teads to rectify this situntion. A 23-It roon with a 27-ft pillar, six row of waste packeges speced 3 ft epart, and a pitch

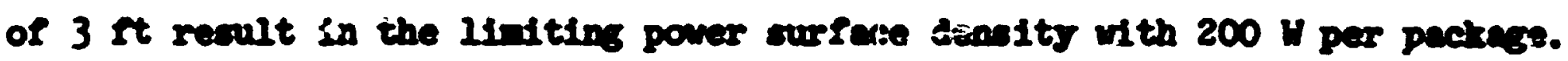

\subsubsection{Parmatre Amlete Ior 2000-It Deth}

one of the sited beins considered for a reponitory has attrective selt formations at a depth of about $2000 \mathrm{ft}$. As the depth increases, the pillar-width-to-roco-ridth ratio mut increase ixr proper support of the

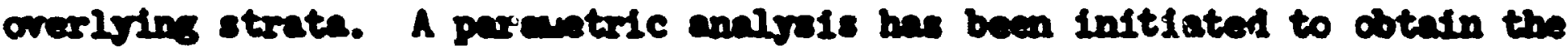
epproperiate tharnil date. Culculations for 10-jear-old vuste in in 18-It-

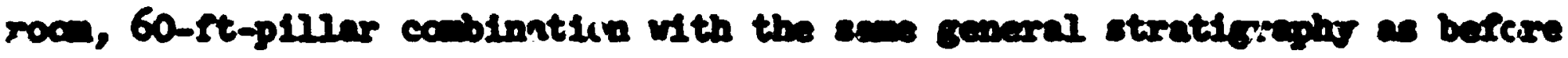

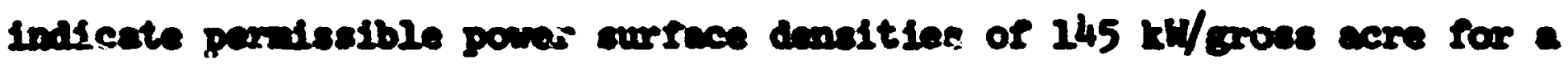
10-It pitch and $140 \mathrm{kl} /$ arose cere for a 30-5t pitch. The carreppondins

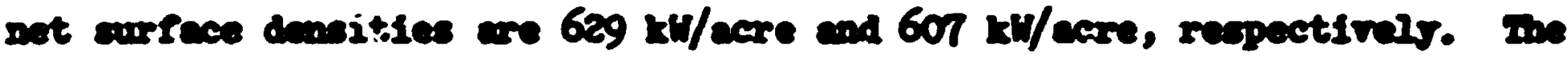

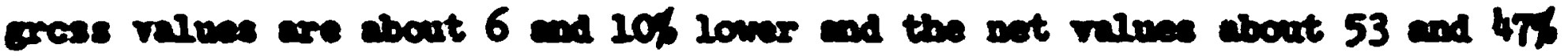
hifer for 10- and 30-ft pitcbes, reppectively, then correopending values for the 18-it roce, 30-It-plllar comination proposed for the 1000-ft depth.

\subsection{5 securecr Copedes}

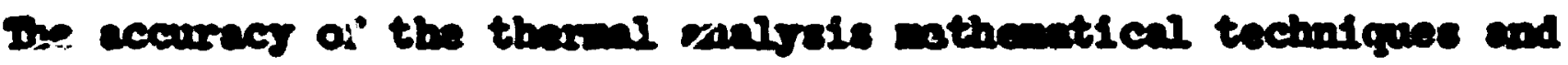

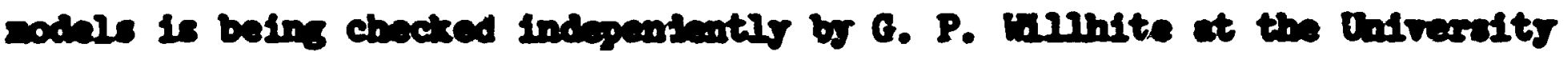

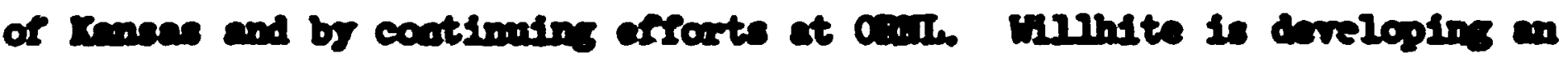

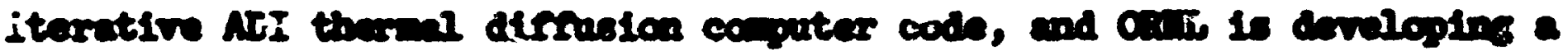

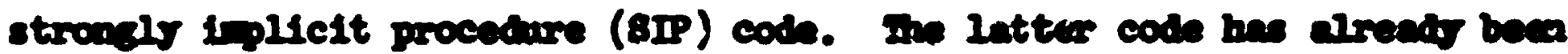

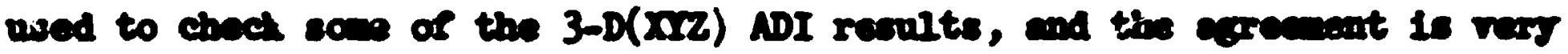

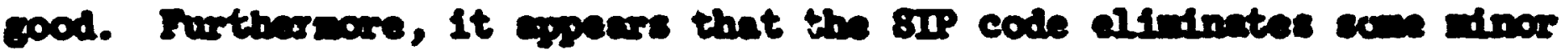

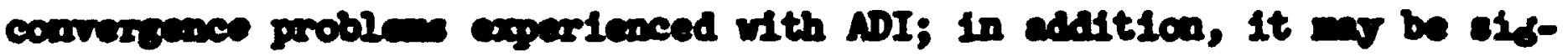
IUflemtly facter then ADI. 


\subsection{5cologacal Assessment}

R. C. Dahlmar.

One objective of ecological assesament is to compile information on pathways of radiomelide nor - nent in ecosystems associated with a saltmine waste repository. By necessity, the assessment is general in scope because no on-site investigative work has been done. Nevertheless, the dyamics of etrontivin-90 has been estinated for plant-soil-1i+ter segments of a generalized grassland ecosystem based on literature sources of information. " ${ }^{6}$ During this report period, efforts on assessment of radionuclide ifmanics in the grassiand ecosystem were focused on radiocesium movement throveh regetative and food chain pathways.

Data were exanined on plant-soil-microorganisa relationships because dicrobes characteristically imobilize, chelate, and circulate minisal elesents. A generic wodel of ${ }^{137} \mathrm{Cs}$ dyneacs was designed for thess somponents if a grassland eccsystem. The conceptual desion closely approximated the

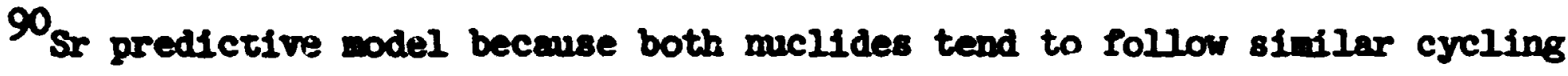
pathways in the graseland ecosystem. A single four-compartwent model (live vegetation, dead vegetation, roots, and soil) accounted for most ${ }^{137} \mathrm{Cs}$ cycling. Alinough microbes are iportant biological agents in the cycing of mineral elements, their inclusion in a generic sense did not improve the rasolution of radiocesium flow in this assessment.

Trus far in cological assessients, it has been assumed that the source of contamination is chronic radioactivity from routine eleases of fission products. Assesement efforts are now beisg redirected to examine ecological consequences of contanination events from upper limit accidents as described by Michols. 47 Generally, pathways and transfer parameters of existing models can be used to describe the disposition of radioactivity for the mjority of accidental releases of fission products, providing adjustmants are made for source-term strength.

Efforts have been initiated to gather inforsation on surface features, so11s, and plant-animal commities at alternative sites being considered in the repository program. Maps and brief ecological data have been assembled fron literatur: sources. However, preliminary field surveys have been delayed, pending selection of an alternative site. 


\subsection{References for Section 3}

1. A. L. Boch et al., Radioactive Waste Repository Froject: Technical Status Report for Period Ending September 30, 1971, ORIL-4751 (December 1971), pp. 146-82.

2. R. L. Bradshaw, F. M. Empson, anu' W. J. Boegly, Jr., Waste Treatment and Disposal Progress Report for Hovember-December 1962 and January 1963, ORRI-TM-516 (January 1963), p. 95.

3. T. F. Kegley, Jr., and F. M. Empson, Examination of Yodified Pillar and Simulated Waste Container Test Heaters, ORiL-Ty-2422 (January 1969), pp. 1-2, 5-6.

4. R. I. Bradshaw and W. C. WrClain (Eds.), Project Sait Vault: A Deanstration of the Disposal of High Activity Wastes in Underground Salt Fines, cinl-4555 (April 1971), pp. 167-170.

5. Tbid. p. 130 .

6. A. I. Boch et al., Radioactive Waste Repository Project: Technical Status Report for Perior. Ending September 30, 1971, OKiL-4751 (Necember 1971), p. 159.

7. R. D. Cheverton and W. I. Turner, Thermal Analyzis of the Hational Radisactive Waste Repository: Progress Through June 1971, 0:ill-4726 (December 1971). p. 23.

8. R. D. Cheverton and W. D. Turner, Thermal Anklysis of the Hational Radioactive Waste Repository: Progress Inrough Yarch 1972, OFuL-4789 (in press).

9. A. L. Boch et al., Radioactive Waste Repository Project: Technical Status Report for Period Ending September 30, 1971, OR.L-4751 (December 1971), pp. 242-44.

10. J. M. Holm, "On the Ifnition of Brplosive Gaseous Hxtures by Small Flames," Phil. Mag. J. Sci., Seventh Ser., 15(98)(Suppl.), 339-43 (February 1933).

11. A. I. Berlad and A. E. Potter, Jr., "Prediction of the Quenching Effect of Various Surface Geometries," Proceedings of the Fifth Symposium on Combustion, Reinhold, Hew York, 1955, Fo. 728-35.

12. A. L. Boch et al., Rajloactive Waste Repositcry Project: Technical Status Report for Period Ending Sertember 30, 1971, 0RII-4751 (December 1971), ip. 156-62.

13. P. C. Carman, Flow of Gases through Porous Media, Butterworths seientif1c Publications, London, 1956, Pp. 9-11.

14. M. G. Zabetakis, Research on the Combustion and Erol colon Hazards of Hydrogen-Water Vapor-AIr Mxtures, USAEC Repixt AECU-3327 (Bepterbar 1956). 
15. J. E. Dolan and P. B. Despter, "The Suppression of Methane-Air Ignitions by Fine Powders," J. Appl. Chem. 5, 510-17 (1955).

16. V. I. Solunskii and A. A. Dobrikor, Soviet Phys. "Doklady" (Bnglish Trans1.) 14, 497 (1969).

17. A. I. Boch et al., Radioactive haste Repository Project: Technical Status for Period Bnding Septe bar 30, 1971, CR.L-4751 (Decenber 1971), p. 179.

18. Tbid., p. 180.

19. G. H. Jenks and C. D. Bopp, Energy Storage in High-Level Radioactive Waste and Simulation and Yeasurement of Stored Energy with Synthetic Wastes, ORill-3791 (to be pubilished).

20. J. U. Blameke et al., An Analrsis of Bnergr Storage and Its Effects in the Proposed Rational Radioactive haste Repository, OFil-TH-3403 (June 1971).

21. A. Rcux, Bargie $\mathrm{B}$ agasinee dans les oxydes $\mathrm{BeO}, \mathrm{Y}_{3} \mathrm{O}_{2} \mathrm{Al}_{2} \mathrm{O}_{3}$ et $\mathrm{SiO}_{2}$ Irradies Aux Deutrons (thesis), University of Ipon; Report 10. CEA-A-4171 (DeC. 1969), transiated by C. D. Bopp.

22. P. C. Gavelle, "Heat-Flow Mifrocalorinetry and Its Application to Feterogeneous Catalysis," pp. 191-261 in sdvances in Catalysis, Vol. 22, ed. by D. D. Eley, Acadenic, Hew York, 1972.

23. G. H. Jenks, Radiolysis and Hydrolysis in SaJt-yine Brines, ORAL-TH3717 (Karch 1972), pp. 13-20.

24. S. V. Pappu and K. A. McCarthy, "On the Colloidal Ceniers in Irradiated Sodiun Chloride Crystals," J. Phys. Chen. Solids 32, 1287-95 (1971).

25. T. Treda and S. Yoshida, "Effect of Divalent Cation Impurities on the Pornation and Bleaching of Colloids in RaCl," J. Phys. Soc. Japan 22, 138 (1967).

26. P. V. Sastry, "On the Colloic Erolution in Alkali Halide Crystals: A Proposed Tentative Mechanise," J. Phys. Soc. Japan 26, 73 (1969).

7.7. E. Sonder and S. In Indenbanm, "Stored Bnergy in Irradiated NaC1," in Solid State Div. Ann. Progr. Rept. Dec. 31, 1971 , ORLL-4779 (April 1972).

28. G. H. Jenks, Radiolrsis and Hydrolyeis in Salt-yine Brines, ORIL-TH3717 ( $\operatorname{March} 1972)$.

29. K. W. Young and A. J. Allmand, "Boperinents on the Photolysis of Aqueous Solutions of Chlorine, Fopchlorous Acid, and Sodiur Hypochlorite," Can. J. Res. 27B, 318 (1949). 
30. W. G. Burns and T. F. Wilians, "Chenical Bffects Associated with 'Colour Centres' in Alxali Baljdes," Nature 175, 1043 (1955).

31. P. D. Schulie and J. R. Hardy, "Prenkel Defects in Alkali Balides," Phys. Rev. B6, 1580 (1972).

32. H. A. Schveinler, ORU, private comumication, June 197 .

33. R. H. Dreyer, R. H. Garrels, and A. I. Bowland, "Liquid Inclusions in Halite as a Guide to Geilogic Thermotry," Am. Mineralogist 34 , 26 (1949).

34. J. P. Hoore, N. L. MeElroy, and R. S. Graves, "Thermal Conductivity and Electrical kesistivity of High-Purity Copper Iran 78 to $400^{\circ} \mathrm{K}, "$ Can. J. Phys. 45, 3849-65 (1967).

35. T. G. Godfrey, W. Fulkerson, T. G. Kollie, J. P. Koore, and D. I. McElroy, Theral Condustivity of Uraniun Dioxide and Areco Iron by an Inproved Radial Btat Flow Technique, ORL-3556 (June 1964).

36. J. P. Moore, T. G. Kc llie, R. S. Graves, and D. I. Mciliroy, Thernal Conduetivity Heasuremente on Solids Between 20 and $150^{\circ} \mathrm{C}$ Using a Comparative-Iongitudinal Apparatus: Results on $\mathrm{Y}_{3} \mathrm{O}, \mathrm{BeO}_{2} \mathrm{ThO}_{2}$

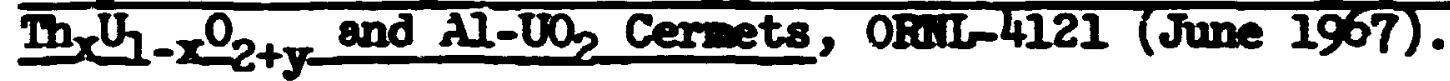

37. T. G. Godfrey, D. L. MaBlroy, and J. P. Ybore, "Develognont of a Powders Radial Hest, Flow Apparatus: Measurenents on Sodiv Guloride and Magnesium 0.15e," peper preaented at the XII intennaticnal Conference on Thermal. Conductivity, Birninghem, Alabans, September 1972.

38. H. W. Godbee, Thernal Conductivity of $\mathrm{K}_{2} \mathrm{O}, \mathrm{Al}_{2} \mathrm{O}_{3}$ and $\mathrm{ZrO}$, Pouders in Air at Atmospheric Pressure fron 200 F to 1500 F, ORil-3510 (April 1966).

39. I. P. Hoore, D. I. MeElros, and R. S. Graves, "Thermal Conductivity of a 58\% Dense 430 Powder in Hitrogen," p. 71 in inernal Conductivity, Proceedings of the Seventh Conference, IBS special Publication 10. 302 (September 1968).

40. W. D. Turner and M. Sinan-Tor, BBAII.G3 - An III 360 Beat Conduction Prosren, aRlL-TH-3208 (Pebruary 1971).

41. T. G. Kollie, D. L. NeBLrog", R. K. Aderas, and J. M. Jansen, "Haasurement Accuracy of a Co puter Operated Data Acquisition Syoten," pepper presented at the 5th Syposium on Teperature, It Keavurenent and Contral in Science and Industry, JBS, Washington, D.C., June 197 (to be published).

42. S. H. Jury, "Mechanically Refrigerst,ed Ice Bath," Instr. Control Systens 40, 118-19 (1967). 
43. A. L. Boch et al., Radioactive Waste Repository Project: Techn:1:al Status Report for Period Ending Sept. 30, 1971, ORiL-4751 (Decewber J.9(1).

44. R. S. Dilion, J. J. Perona, and J. O. Blomeke, A Nodel for the Economic Analysis of High-Level Radjosctive Waste Manngement, ORII 4633 (Novenber 1971 ).

45. J. 0. Bloneke and J. J. Perona, Storage, Shipment, and Disposal of Spent Fuel Madding, ORIL-M4-3650 (Jamary 1972).

46. A. L. Boch et al., Radioactive haste Repository Project: Technical Status Report for Period Snding Sept. 30, 1971, ORhL-4751 (Decerber 1971), pp. 251-93.

47. Ibid., pp. 296-323. 


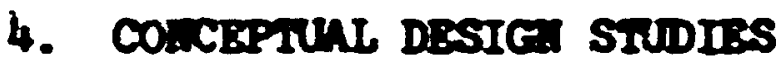

Taiser Boginecrs, Incorpareted, we retained during the past jour to contive architect-engirser (A-B) services on behalf of the concoptun desion of the salt-rine repository. A Coneptonl Desin Bupot for the

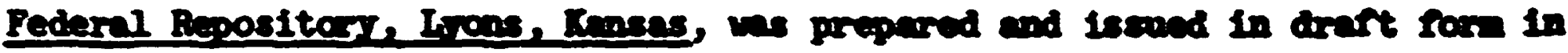

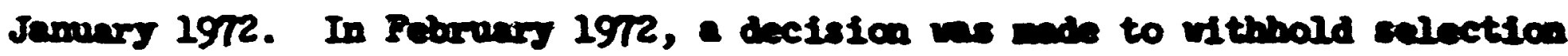
or a specific stie teporarily and to puraw the dosign and constaction

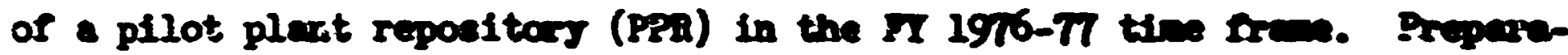
tion of a cosceptanl desion and subittal of a contruction date sheet were scheduled for copletion by the and of II 1915.

\subsection{Pllot Plant Bepositoor Concept \\ B. F. Bottenrield G. U. Bunro}

3. J. Irodarick

\subsubsection{Scopend Definition}

The objestive of the PPB is to provide the newe fix renalifin the

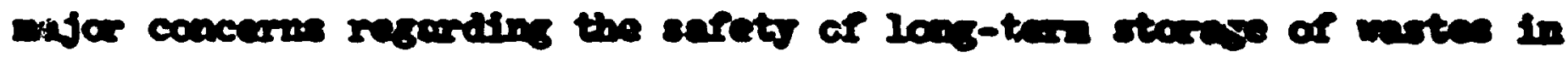

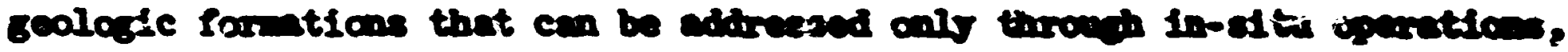

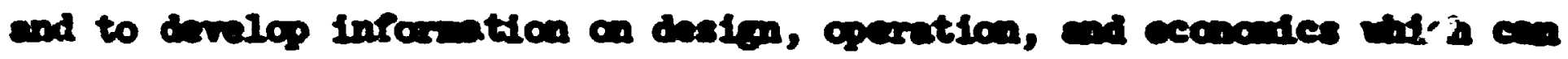

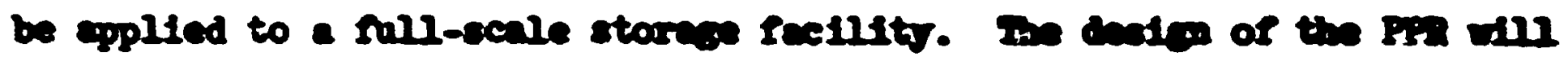

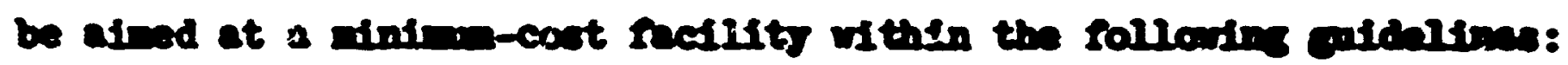

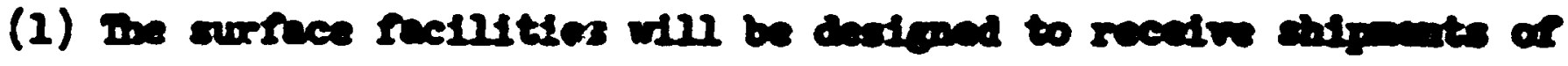

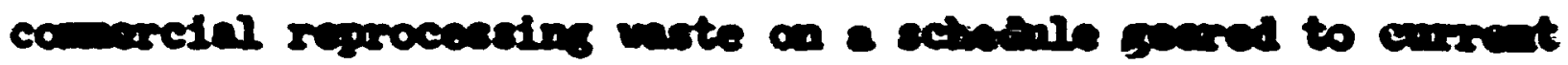
profected production rates for these wetes thiond the wh-

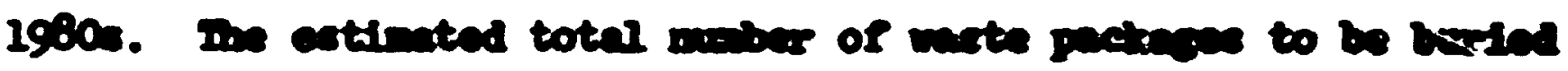

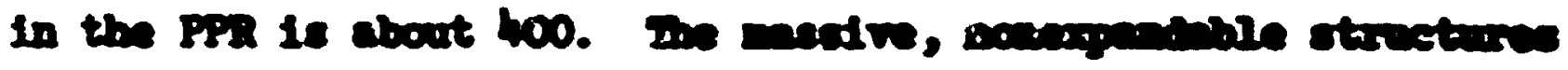

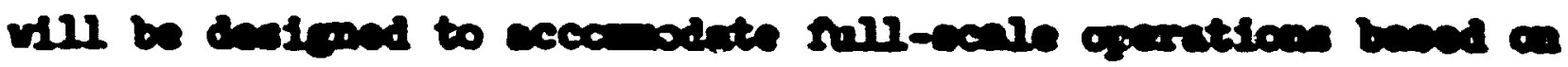

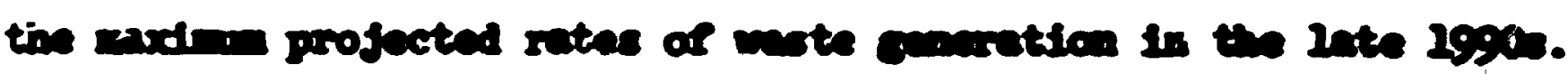

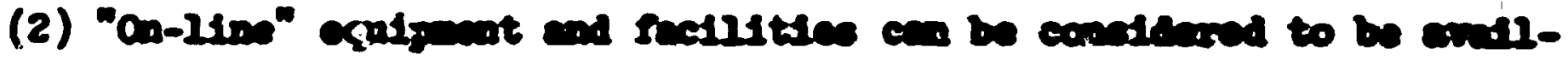

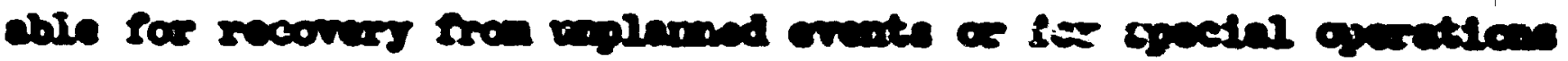

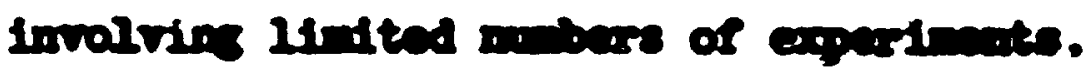


(3) All waste packagas will be essentially free of external contamination, and the waste will be in an approved fore. The means for establishing this level of cleanliness should be provided elther at the pillot facility or at the shipper's plant.

(4) NII wote pacinges eqplaced in the formation will be monitored and nintained is required to prevent mpratian of the waste and to ensure rapid retrievability. This does not prohibit liaited eqpurinoutition, at a later date, in which special provisions are provided beforehad to allow retrieval of even bare vastes.

(5) Adegnte instrumentation vill be installed in the storage rocms ad elsentere to mite all necessury mourenents of teperature, radiation, gross phraical changes, stresses and strains if zeologic structares, repor pressure, water hou and baildup, etc.

(C) Site selaction, site size, and desion of the PPR should not preclude its conversion, at the conclusion of the pilot preraiton ptase of the progre, to an cperaticanl storage facility. The duration of the pilot operation pbase is assuned ts be 5 to 15 joars.

(7) In foctlity dacian will include en ecologically acceptable weans for usposits of axess salt.

(8) Eo frovisises for alphe wote burial should be ande in the pilot rectitis deston.

(9) The salt lave for mote dispoen will be ussuned to be situated axce ft belour the surface.

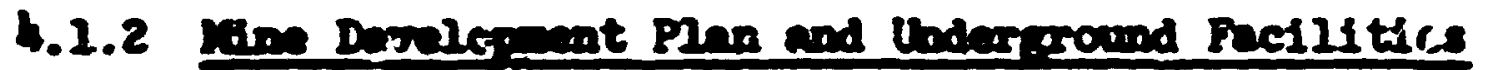

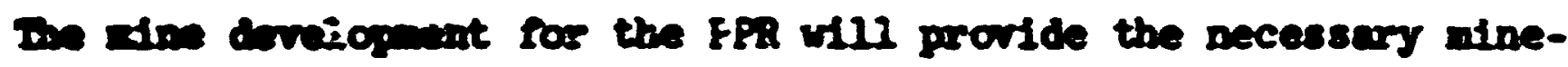
Iovel faefuties fer buyding and rotrieving waste packages within sleeves

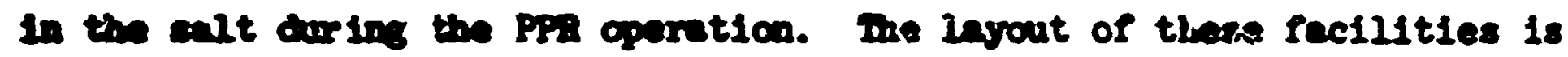

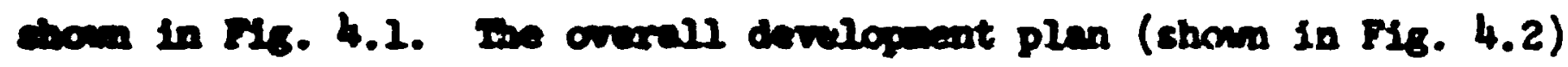
indeates the ralntionstp of the PFA nine to possible Nuture rall-scale repantion located in the 2-sgurre-nile salt laver. 
ORNL DWG 72-10372

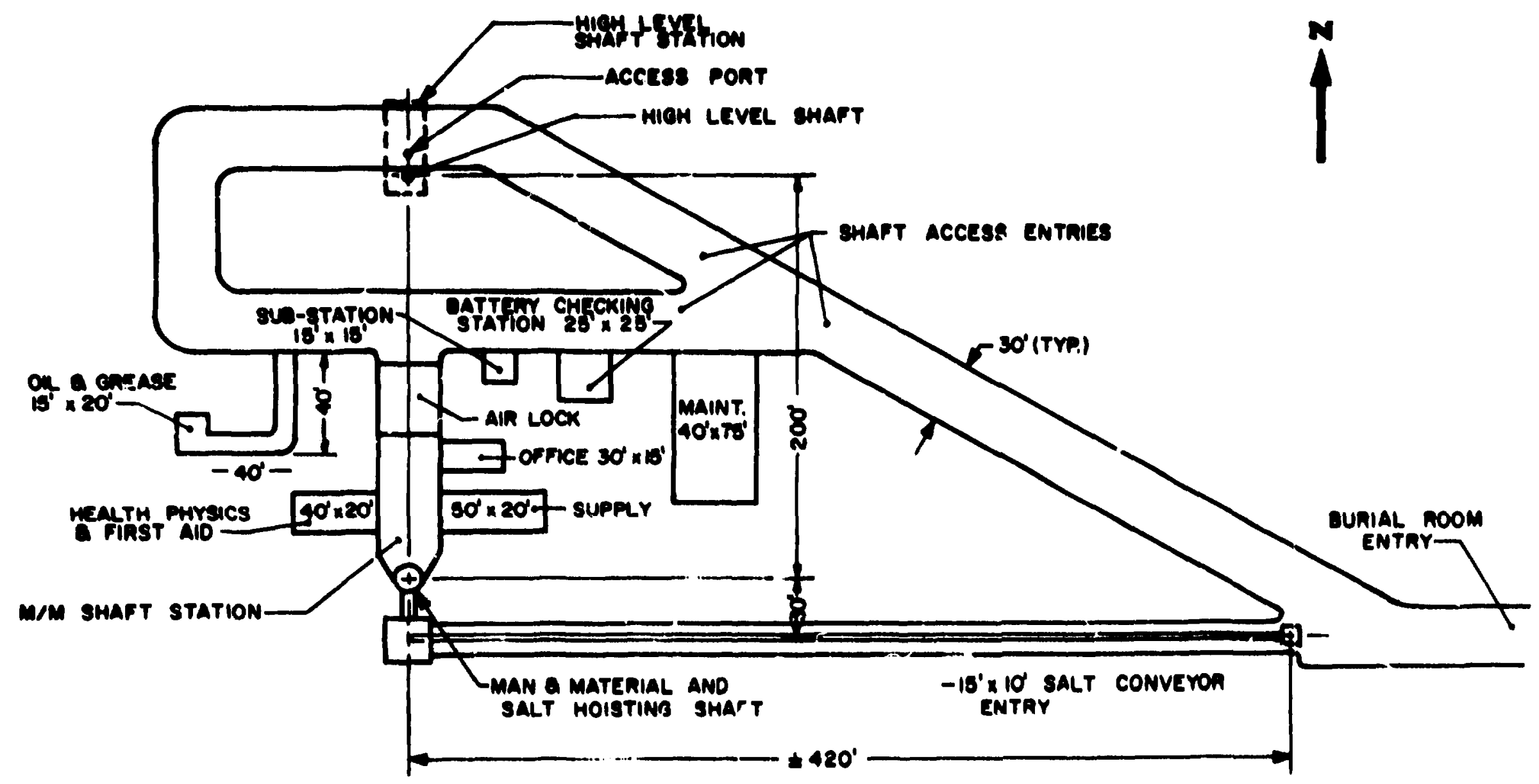

F1g. 4.1. Auxiliary Underground Installations. 


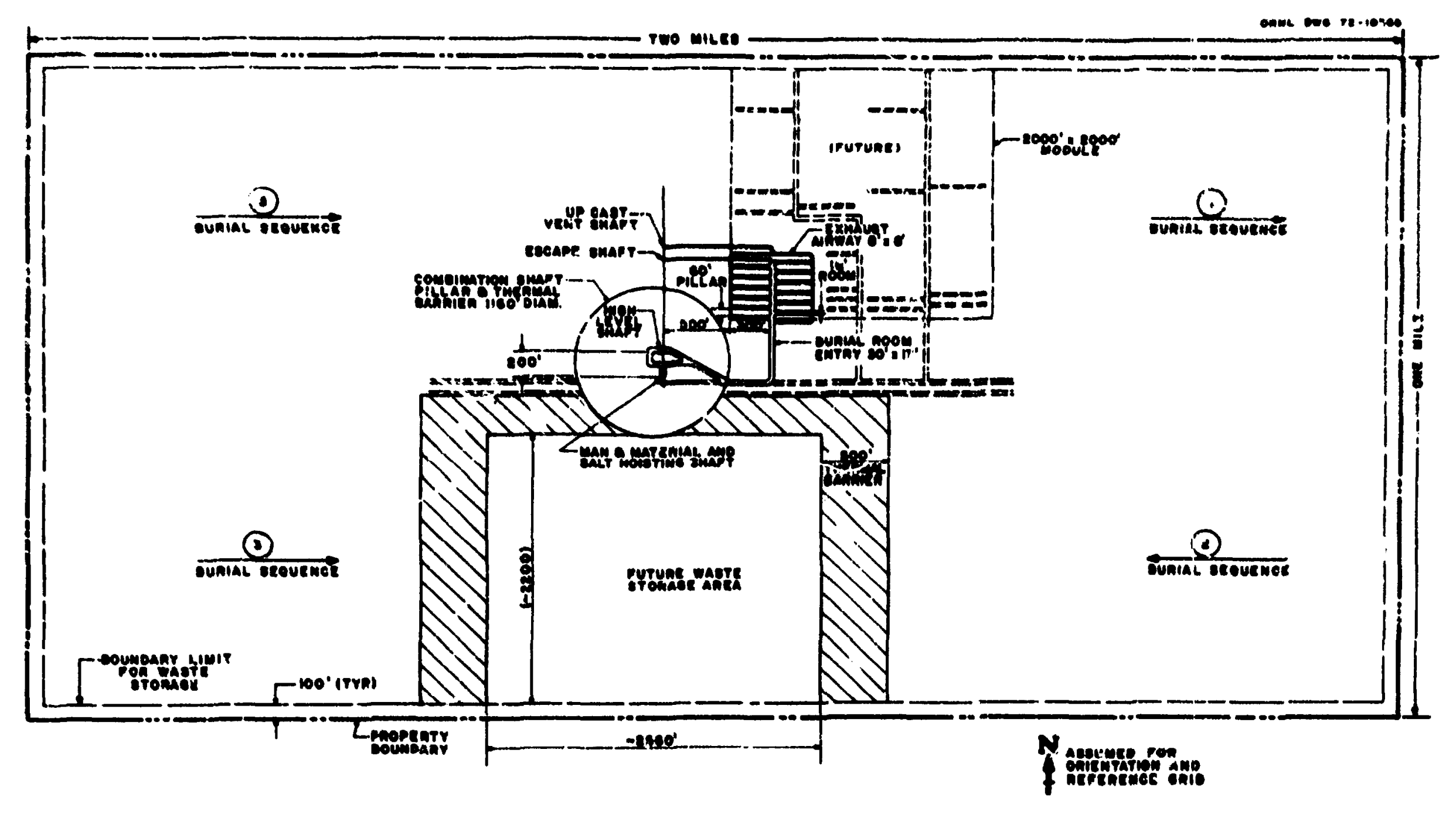

Fig. 4.2. Mire Development Plan. 
The salt excavetion for the PPR is to conpleted during the constraction phase of the project and in the nost coononical ws. Wo salt will be rewoved from the aine during PPA operation; eccess salt resulting from drilling holes for the burlal of wate packeges vill be retaind in the mine. Four significant features of the moderground faclities are a.s8cribed below.

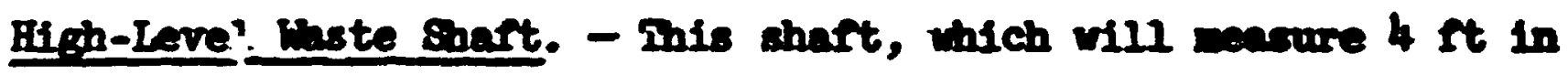

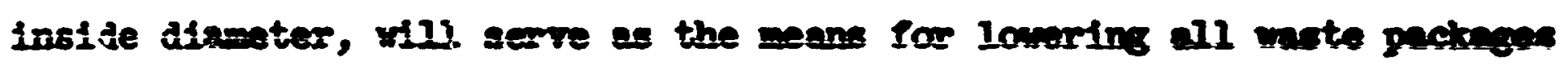
from the surface facilities to the wine, and for retrieving those packonges from the IPR in the event that it becanes neceasary to trenserer then to another repository at the conclusion of the pilot plent operation.

Yey.and-leterials and Bult Bolsting Shaft. - Inis multpurpose chaft will messure epprodinately $14 \mathrm{ft}$ in inside dinneter and will be partitioced to provide for the following equipment and functions:

(1) A hoist and cage for trensfer of men and meterials frow the surface to the mine.

(2) Ifjisting capability to remove excess ealt from the mine.

(3) Ventilation air supply to the rine.

(4) space for mine utility and service ducting.

(5) Venway and lodder for ewergency egress fron the wine.

The shaft will be sized for the PPR only; additional capacity, if required for a future full-scale repository, will require a new shaft.

Upcast Ventilation Shaft. - This shaft will be sized Ins the rentilan tion cepact.ty of the PPR mine and will be partitioned to inciude a recond emergency exit from the mine.

Support and Service Facilities. - Facillties will be provided nndergj:ound for se:cricing mining and waste handling equipmont, oil and crease storage, underground electrical distribution, first afd, and an office for mine-level supervision.

\subsubsection{3urface Facilities}

The surface facilities, which are to be ccrstructed in a manner that does not preclude expansion, w12l be sized to accomodate a raste package throaghput equivalent tc, that projacted for the PPR, suld for the stafe of 
personnel required tc process these packages. The mssive concrete cell structures and busenent structures, wose expansion to a future rullscale repository would be exceedingly difficult, will be sized for the Null-scale repository capacity.

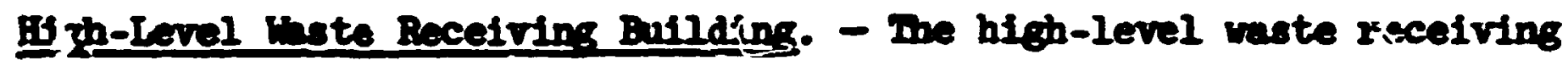
buslding wil contain fucilities for recelving fail cars or trucke cerrying wate casks reighing up to 210 tois, unloading the casks rrom the rail cars, cooling the massive shielding of the casks, unloading the raste packages from the casks renotely within a shielded cell, and loverling the packages into the wine through the high-level waste shart. The floor plans of the two floors of the building ere show schematically in Figs. 4.3 and 4.4 .

\section{Support Pacilities. - (1) Salt isopoial. - Minino facilities for} loading the nined salt into rafl cars or trucks for transport and disposal will be provided at the top of the salt hoisting shaft; this capacity will be sized for the PPR only.

(2) Cer ral Pilter Station. - The filter station provides for the safe cleanup of the dine ventilation exhaust air at the top of the upcast ventilation shaft. The station ws.ll be located below grade.

(3) Mine Operations and Aduinistration Building. - This building will contain quarters for the administrative staff of the PPR as well as facilities for carrying out certain functions relating to pe:sonnel working underground, such as the changerocm and personnel mantoritis station.

(4) Other surface support facil.1tie: include an explosives magazine, varehouse and materisl staging anc receiving :pace, an electrical subsication, and a water supply tank.

\subsubsection{Ventilation and Confinement System}

The confinement zones of the high-level waste recelving building will be designed and corifiricted so that waste handing operations can be shut down without endangersp: che public health and safety during or following, an earthquake or a tornado. Confinement zones will be maintained at negative statin air pressure with respect to the outside atmosphere to 


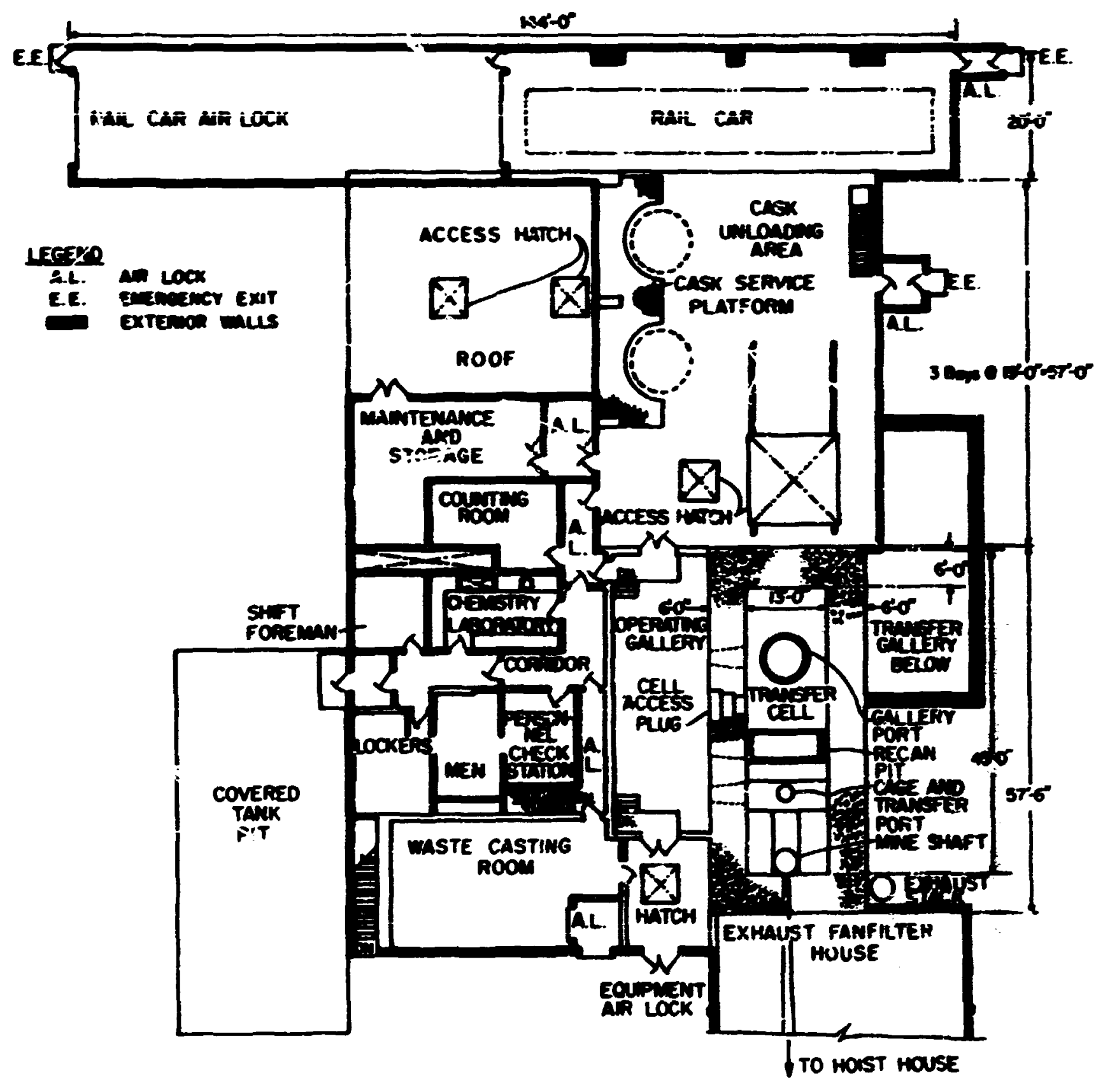

Fig. 4.3. Plan of the Ground Floor. 


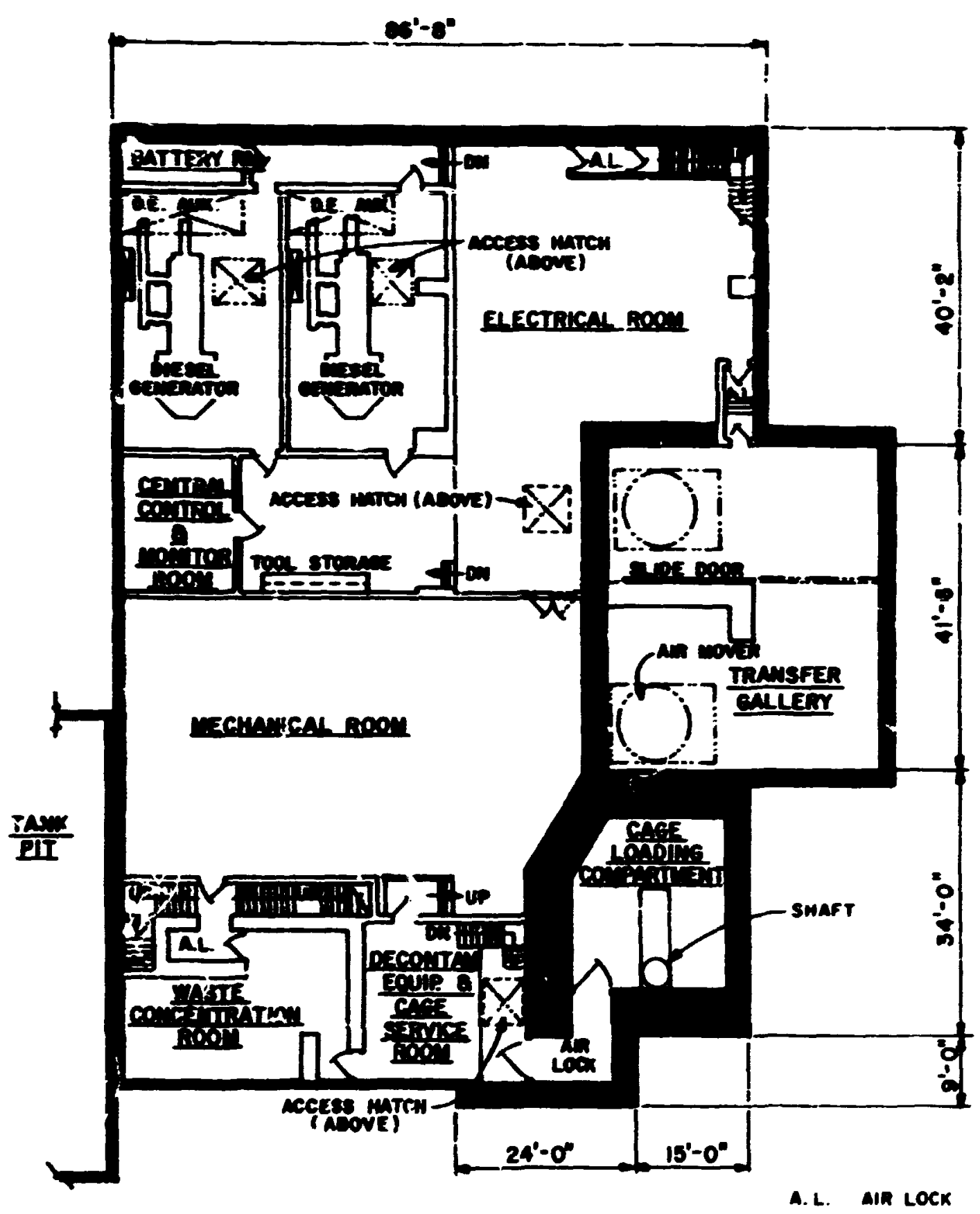

Fig. 4.4. Plan of the Basernent Floor. 
ensure against ar,y cutleakage of air (see Fig. 4.5). All exhaust air from confined areas of the building will be passed through fans and HIPA filters, located in an exhaust fan-filter rocm, prior to discharge to the atmosphere through a stack. Access between confined and unconfined areas of the building will be gained through air locks.

Ventilation air will enter the wine through the air supply comartment of the men-and-materials and salt holgting sheft. Whin the mine, the flow of ventilation air will be directed toward the waste burial erea via the main and panel entries. A separate tunnel system located abore the main entries will serve to isoiate the exhoust air streams from the working areas and convey them to the base of the upcast rent shaft.

\subsubsection{High-Lerel Maste Handling System}

Waste will be received in sealed cans up to 24 in. In dianster, wp to $10 \mathrm{ft}$ long, weighing ut to $8000 \mathrm{lb}$, and generiting 1 to $5 \mathrm{~kW}$ of waste heat. These cans will be shipped in casks weighine as wch as 110 tons. The temperaturas of the cans will be lowered by ccolling the ahielding cesks; and the cans will be unloaded individually is shielded cell facilities, lowered to mine level through the vaste shaft, and then transported and buried in the salt bed usirg a shielded transporter.

A section through the high-level building is shown in Fig. 4.6. The shipping cagk will be lifted fror the railcar and lorered through the hatch in the floor of the cask unloading area onto an air transfer pallet in the air lock. It will be moved laterally intc the cask service area, where the massive shield will be cooled by circulating watar through the nentron jacket or channels in the shield. Finally the cask will be wored to a location under the cask port in tho shielded transfer cell, where the cask will be sealed to the bottrym of the cell. The cask port cover and the shipping cask shield plug will aubsequently be removed, exposing the waste packages and the cask interior to the cell. Then the waste packages will be lifted from the cask individually and lowered into the mine shaft cage, which is located below the transfer cell port. The mine shaft cage, containing the waste package, will then be lowered to mine level.

* HFPA = rigi-efficiency particulate air filters. 


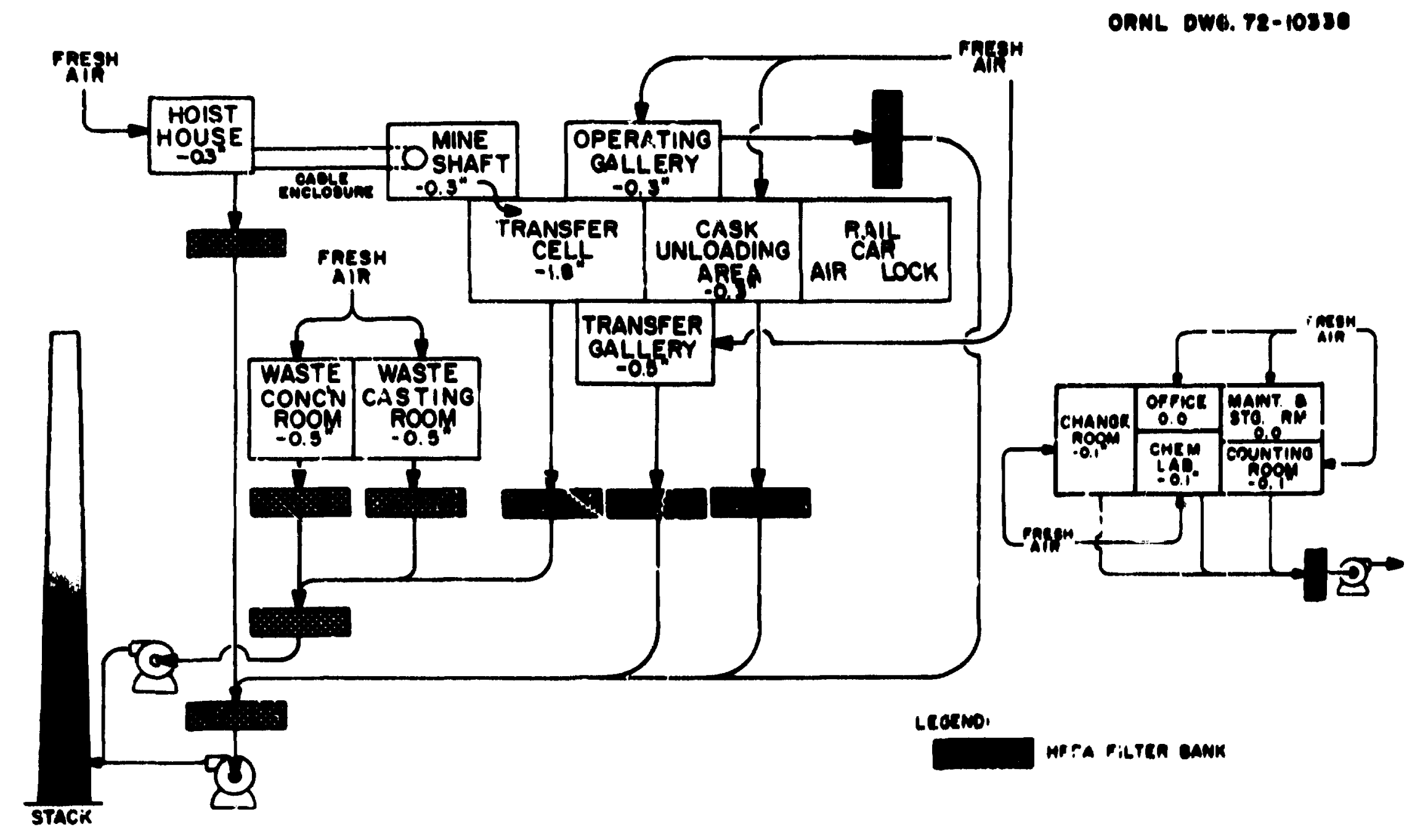

F18. 4.5. Schematic of thes Ventilation System for the Waste Recelving Bullding. 


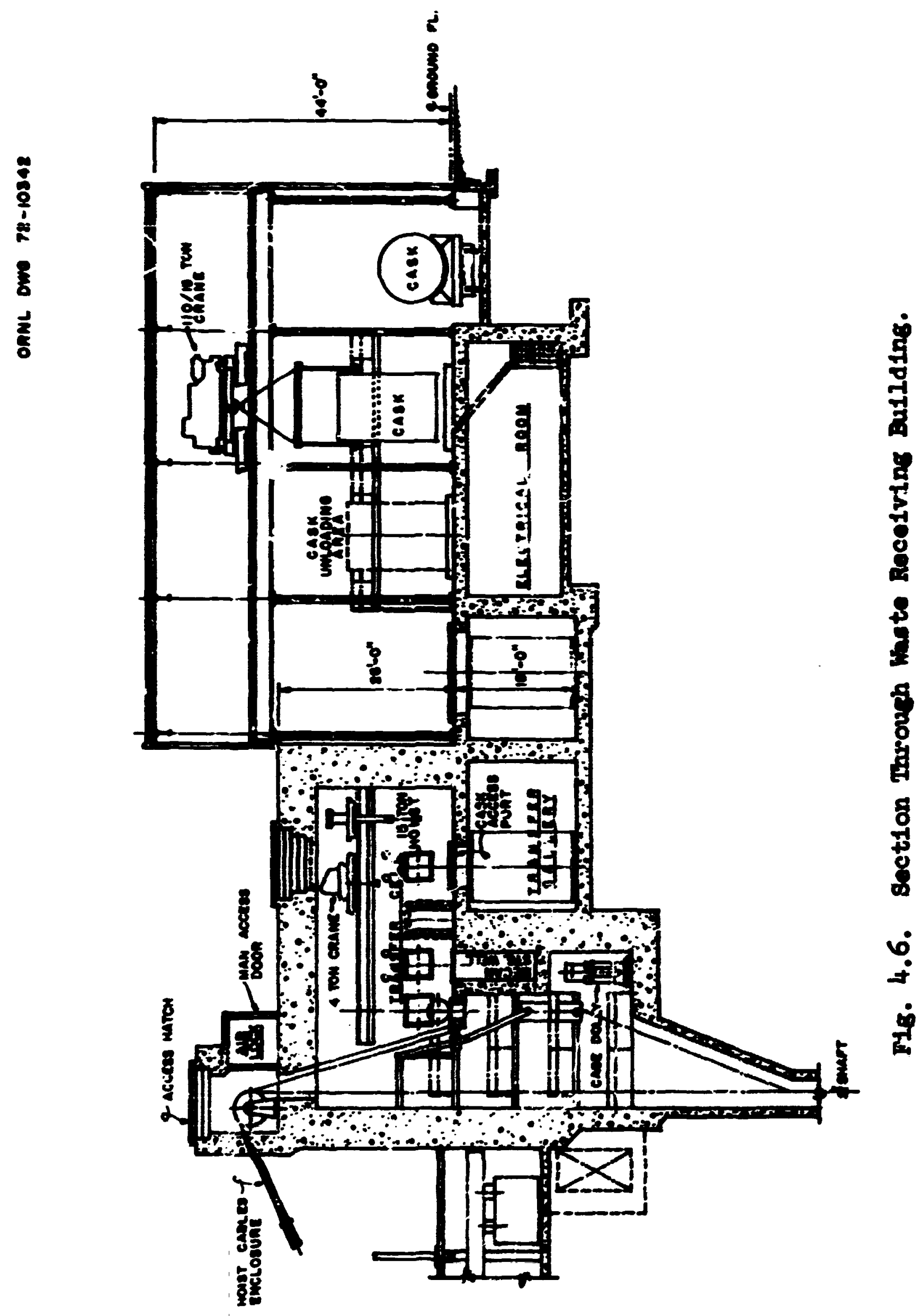


At aine level, the cage vill be received in a shlelded station (see Fig. 4.7). The cage will be noved laterally to a position under a port in the top of the station, through wich the raste package will be holsted into the waiting shielded transporter. The waste packege will be transported within the shielded transporter to the wate burial area, where it will be depoeited in a previously prepared kole baving an inart liner.

\subsubsection{Schedure}

Our schedule is contingent upon a great nav coasideretions, not the least of which are Congressional appopriations and legislation anthorizIng us to proceed in certain areas. Other ipartant consıderations are, of course, the results of current and proposed research and developinent activities, particularly geologic-hydrologic investigations and consideration of alternative sites.

Our tentative schedule includes completioi of a conceptual design stids and report, besed on a site near Carlsbad, lew Haxico, by Much 1975, and preparition of a construction project data sheet by Jure 1975. The date sheet will propose funding of the pilot plant repository project, with conpletion of construstion scheduled for the early $1980 \mathrm{~s}$.

\subsection{Waste Package Comector}

H. I. Preston

The design for a connector that can be used in the remote handling of high-level waste containiers at spent-fiel reprocessing plents and a repositnry was completed. A jrototype connector was fobricated and has been subjected to preliminary cyclic and strength tests. The results of these tests, which were conducted for 4000 cyclss with no load and for approximately 16,000 cycles with load, indicate that the connector excersis the basic safety and loed criteria. Future testing of the connector is planned in order to further evaluate its remote opereting capabilities, its underwater operation, and the effects of heat on its performance. The connector design and the testing program are dascribed in a topical report. 1 


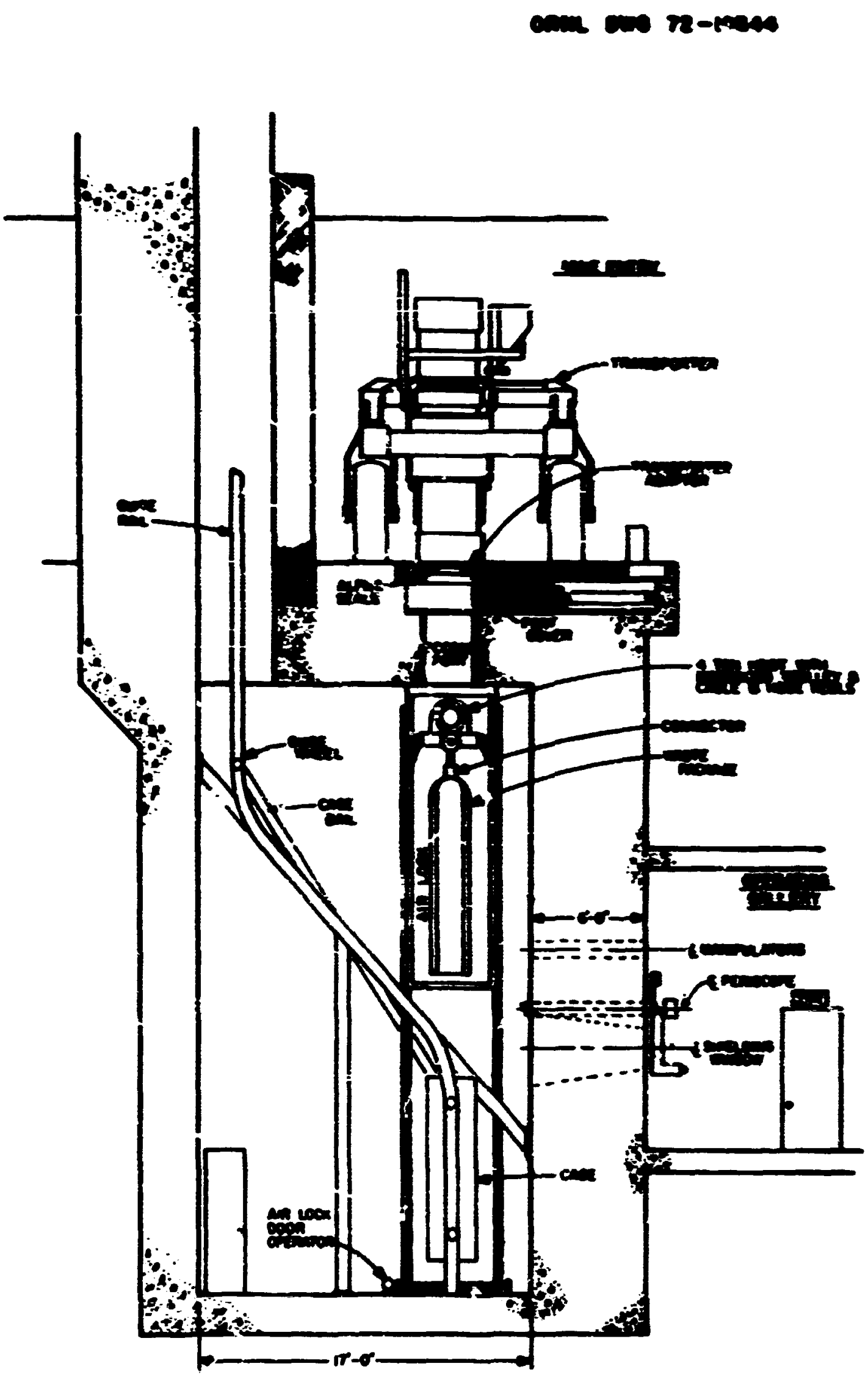

Fig. 4.7. Section Through He-Levei Shaft Station. 


\subsection{Ret sievel Concepts}
B. P. Bottensield
G. H. Rantro

A conceptanel study of waste package retrieval alternatives was conducted; and a prelisinary report, "Conceptunal study for Retrieval of

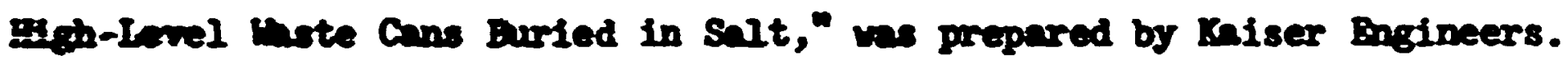
The report ircicdad five draringe and described concepts for retrieval

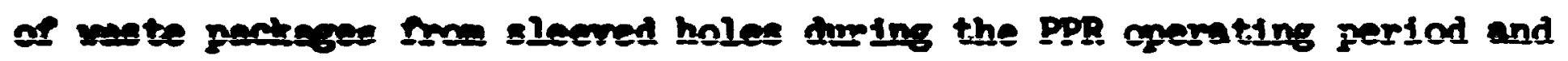
fron direct burial in salt for longer-range planning. The sleeved burial concest will not be developed on further at this tine; this phase of retrieval destem wil be the reaponsilility of the PPA operating contrector and will be infilated after the PPR is in operation.

\subsection{Inzer Integrity studies}

\section{R. B. Adeng \\ D. I. Manror}

I. G. Goarrey

During the operation of the pillot plant, it is sonsidered necessary to eplos a double containnent system for the high-level waste paskages t) ensure operstional safety, to allor certatn experinents to be performed, and to provide a positive noans of waste retrieval (in case renoral becones necssarary or desirable). We have concur ted a desk study of this lined-hole concept with the goal of suggesting one or nore candidate naterials for experinental verification.

Experience has shown that the stainiess steels are the best of the camion naterials from the stanchoint of general resistance to corrosion. Horever, it has been clearly demonstrited that stainless steels are suivject, to gross stress corrosion cracking in a salt-bearing environment. Coman carbon steels, on the other hand, experience a more rapid, but uniform, corr sion rate. Several special allogs, such es linst:lloy $C$, have a high resistance to corrosion, but their unit costs would be 10 to 50 times greater than those of the more common materials.

Our study has indicated that a carbon ateel--concrete corposite might be the best candidate for further study. High-temperature ceirents with silice flowr : :or ageregate have been developed for application in 
the petroleum industry to seal oil well casings to the rock strata for steam injection to simalate oil flow. These cements, which withstand temperatures up to $700^{\circ} \mathrm{F}\left(371^{\circ} \mathrm{C}\right)$ and have strengchs as high as 15,000 psi, have also been successfully used in salt formations.

This concept would employ a thir ( $1 / 4-i n$.$) steel closed-end tube$ as a permanent form in the oversized hole in the salt, with the special cement or concrete purured in piace in the $1-1 / 2-$ to $2-i n$.-vide salt-steel annuius. The concrete is the principal strengtin nember, while the steel liner serves as the form and prevents chips from clogging the cavity in the er.nt the concrete spalls. in most cases, nylon or steel fibers have been used as reinforcement in these cements; conrentional wire wesh or rods would seem applicable fï our use if thermal and solidification expansion characterisicics can be adjusted for this purpose.

Although satisfactory performance of these cenents in salt at high temperatures has been demonstrated, an experimental progran will be necessary to establish their suitability for long exposures to the thermal, mechanical, chemical, and nuclsar environment of a salt-wine repository.

\subsection{Repository--Fuel Reprocessor Interfaces \\ B. F. Bottenfield \\ J. 0. Blaneke}

G. W. Renfro

Meetings were held during the past year with personnel from three of the potential fuel ieprocessors who will supply high-ierel waste to the PPR and the engineered storage facility: Allied-Gule maclear Services, General Electric Company, und Jersey luclear Company. A set of waste cask and package acceptance criteria was prepared by Canl in advance to provide a focal point for the discussions. The neetings provided a free interchange of ideas on such subjects as the follourns:

(1) Shipping Casks

a. Maximum diameter and length

b. Maximum weight

c. Internal void dimensicns 

d. Sealing to repository transfer ceil
e. Internal casi: atmosphere
f. Fabrication tolerances
g. Cask cooling
1. Contamination tolerances
i. Connections and appurtenances

(2) Waste Packages
a. Maximum diameter and length
b. Maximum weight
c. Method of handiing (connector)
d. Maximum heat generation
e. Maximum temperatures
f. Fabrication tolerances
g. Co.stainer integrityr
h. Contamination tolerances
i. Waste projerties

(3) Other

a. Rail car limitations

Based on many of tine comments received from the reprocessors, we have revised the interfacial criteria in a number of respects for ccusideration by the AEC and participating contractors.

\subsection{Ref $\epsilon$ rence for Section 4}

1. M. K. Preston, Development and Testing of a Connector for Remote Handling of High-Level Waste Containers, ORNL-TM-3934 (September 1972). 
5. PITOT PLANT EXPERIMENTAL PROGRAM

R. D. Cheverton

The objectives of the piloi plant operational period are basically (1) to demonstrate the ability to transport and handle high-levei waste without mishap, and (2) to confirm various technical aspects of the burial scheme. Only enough warte need be buried to accomplish these objectives; however, all of this waste must be readily retrievable. The duration of the pilot plant experiments is indefinite but is expected to range up to 15 years.

Details associated with the presently proposed experiments are discussed below.

\subsection{Transportation and Handling}

To adequately demonstrate safe transpcrtation and handling capability, many waste packages will have to be shipped to and buried in the pilnt plant. A reasonabie number for this purpose appears to be about 100; however, since the actual number of packages buried will derand on requirements for other experiments, the total could range as high as i000. At lesst some of the packages should have a power level as high as is expected in the near future on a routine basis; this might be as much as $5 \mathrm{~kW}$. It is expected that, on receipt ai the pilot plar", most of the packages will have pciser levels of 2 to $3 \mathrm{kth}$ and that the age of tire waste will be 10 years.

At the time that the wrste is buried, some question regarding the integrity of the coitainers from the standpoint of both internal and external corrosion will probably still be unanswered. Because of this and a desire for positive and rapid retrieval capability, it is tentatively proposed that the waste packages be placed in a secondary container and that the burial hole in the salt be lined witin a relatively permanent material such as a ceramic or a ceramic-lined metal sleeve. A backfill material or grout would be required betveen the sleeve and the salt, and this combination must be capoble of withstanding the compressive forces to be imposed on them as a corsequence of salt flowage. 
The exact nature of the secondary containment vesse? rill depend on the type of experimental data that are to be extracted from the waste package. Figure 5.1 indicates one possible design concept in which the cavity between the primary and secondary ccntainers is not nezessarily sealed at the top. Leakage of volatile radioisotopes from the primas $y$ contain $r$ would indicate a breach of that vessel which could be detected by purging the cavity between the primary and secondary containers and sampling the gas. A inermocouple well is included along the axis of the waste package through the savpling to ailow periodic measurements of the waste temperature. A sheathed thermocouple extending through a sulll hole in the shielding plug into the thermocouple well in the waste pacikage would be used to make these measurements. Thus, no instrument lines would have to be attached directiy to the package to obtain temperature and leakage data.

Monitoring of the waste will be performed continuously on a representative number of the packages. Variables to be measured will include the center-line temperature of the waste, the surface timperature of the conte.iner, and the contents of the purge $\tilde{\delta}=s$ between the primary ard secondary containers. In addition, waste packages and their secondary containers wili be pei-iodically withdrawn from the sleeved holes to allow wall thickness and out-of-ioundness measurements of the sleeve and to demonstrate retrievability.

We do not anticipatc that any of the rooms will be backfilied during pilot plant operation unless such an operation is required for acquisition

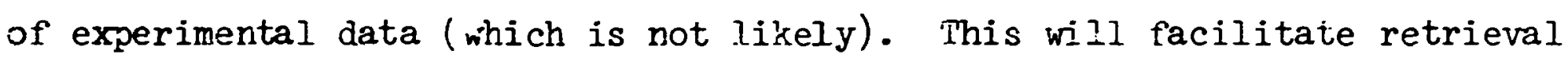
efforts. Furthermore, sufficient vertilaticis capacity and flexibility will be provided to cocl sejecific roms that must be entered for monitoring or retrieva? of the waste.

In the event that the primary container is breecned during pilot plant operation, the defectiva waste packaye will be moved to the aboveground transfer cell and recanner.

All phases of handling, with the possible exception of revanning :- 4 retrieval, will be encountered during the transfer of the waste package f:.... the railcar to the burial holes. Since the secondary container will be atiached by the reprocesscr, visual inspection of the outer surface of the 


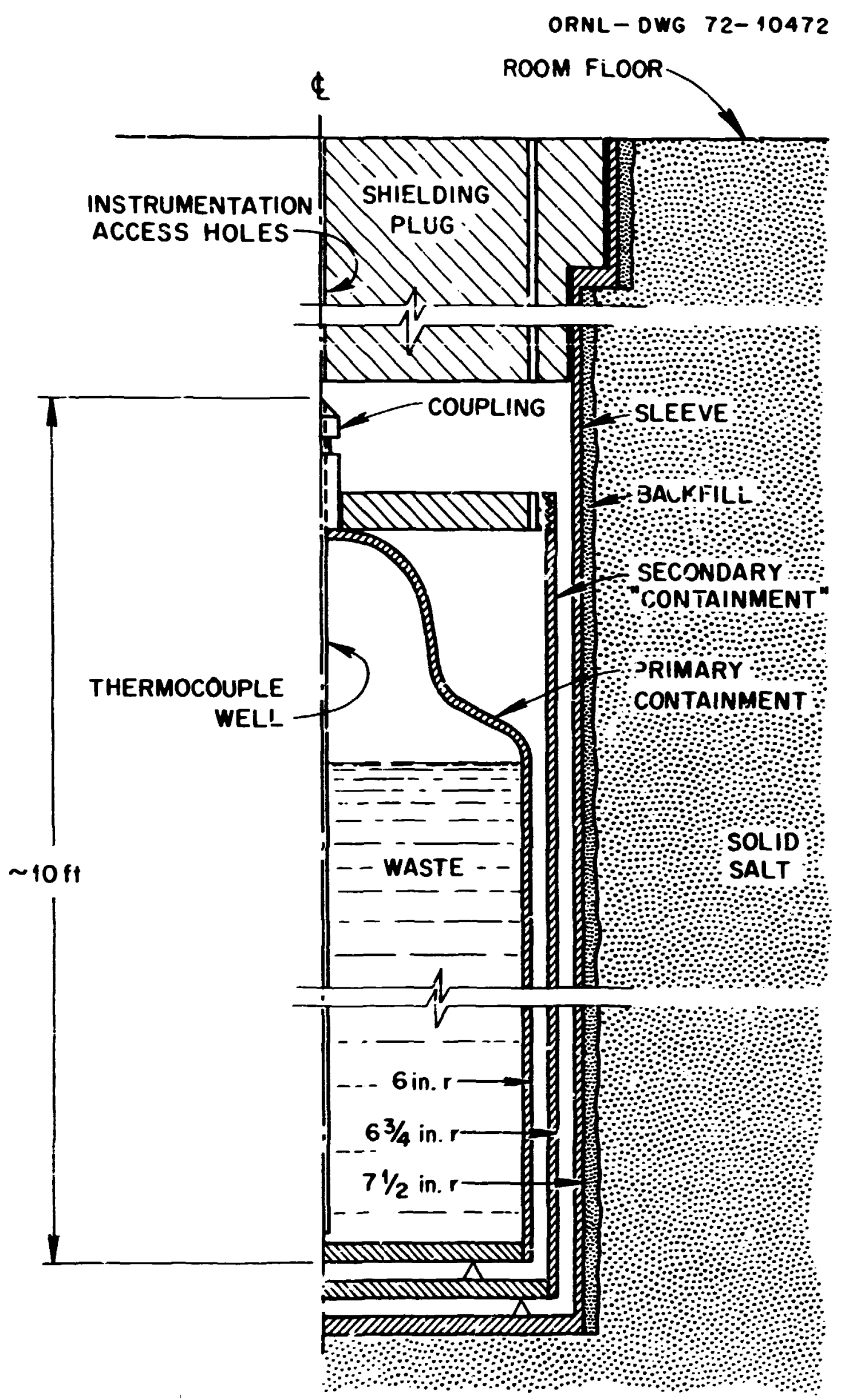

Fig. 5.1. Schematic of waste Package and Its Secondary Container in Sleeved Hole. 
primary container on receipt will not be possible. ince existence of a defective package can be ascertained, however, by sampling the primary coolant rised in the shipping cask.

\subsection{Experinental Program}

The presently proposed experimental program covers the areas of heat remoral, formation and release of explosive and noxious gases, fissior. proiuct transport, and rock mechanics. Lach of theso is aiscussed separately in the subsections that follow.

\subsubsection{Heat Remcral}

The proposed heat removal experiments are intended as a check on the accuracy of the calculations, and as a means of providing information on the rate at which the thermal conductivity of the crushed salt backfill changes. For the calculational-check experiments, it is desirable to have one isolated waste package plus a second parkage located in the middle of an "infinite" array of packages. At a depth of $2000 \mathrm{ft}$, an infinite array will require an arsa about $350 \mathrm{ft}$ square. Since the roms ars to be $18 \mathrm{ft}$ wide by $300 \mathrm{ft}$ long, separated by 60-ft pillars, and placed on opposite sides of a corridor, it is proposed that ten ruoms occupying a gross area about $600 \times 400 \mathrm{ft}$ be considered. The maximim permissible gross surface power density is expected to be about $140 \mathrm{kw} /$ acre for 10 -year-old waste. Thus, assuming that essentially all the warte is 10 years old and is packaged in containers evilving $2 \mathrm{~kW}$ of power, the required number of waste packages is about 400. These packages and the isolated package (which will be located at least $10 \mathrm{C}$ ft from the outermost package of the arrays) sill be placed in sleeved holes, and the sleeres will be grouted in place with a material having thermal properties similar to those of solid salt.

The only instrumentation required for these experizents wil] be thermocouples. Some of the thermocouples will be placed on the inside sirface of the sieeve and at several other radial positions farther out in the sa:t. All of these thermocoupie junctions will be located at an elevation corresponding to the horizonta? midn?ane of the waste package. The cthers will be placed on the floor and walls of the room and in the pillars. 
The calculational-check experiments will primarily yield data that can be used in comparison with the thermal properties of the various surrounding formations since the stratigrapkic detail will be well known and the thematical model will have been evaluated previously. If the calculated results compare favoreily with those obtained experimentally, extrapciaticns in time can be performed satisfartorily.

To check on the time-dependent thermal properties of the backfill, it will te necessary to have an annulus of crushed salt backfill surrounding the sleeve of the waste package in the midst of the infinite array, as well as the sleeve of the isolated package. Presumably, the latter arrangement will result in a slower rate of reconstitution of the crushed salt.

The experimental procedure will consist of comparing the surface temperatures of the waste containers buried with grout around the sleeves with the temperatures of those having crushed salt around the sleeves. It is expected that the packages with the crushed salt backfill will experience two peaks in their temperature-vs-time curves as opposed to a single peak achieved witk a solid "backfill." The latter peak, which occurs in about 20 years, results from the combiner effect of thermal capacity of the various fornations and radioactive decay of the heat source. The earlier peak associated with the crushed salt backfill results from the combined effect of thermal capacity and increasing thermal conductivity of the backfill, and will occur in about two days. If this peak is sraller than the second one, and if the thermal conductivity of the transiorming backfill closely approaches that of solid salt within a reasonable time, the backfill will not impose a thermal limitation. In the event that these conditions are not achieved, a, more restrictive limitation on mine loading will result.

\subsubsection{Formation and Release of Explusive and Wxious Gases}

The proposed long-term waste burial scheme calls for emplacement of a waste package directly in the salt without secondary contaiment or a sleeve. In the absence of a "noncorroding" sleeve in the hole, hydrogen will be produced by reaction of the metallic container with the brine that migrates through the salt to the waste package. Hycirogen will also be produred in the vicinity of the waste package as a result of radiolytic decomposition of the water present in the brine. It is possible, although 
very unlikely, that poteniiaily explosive mixtures of air and $H_{\varepsilon}$ will exist in urventjlated backfilled rooms. If necessary, however, several design and/or operational changes could be implenented to alleviate this hazard. In either case, experimental data are required to resolve the questions since uncertainties in the calculations are considered to be excessive.

Two experiments are proposed, the necessity for one depending or the results from the other. In the first experiment, gases emanating from the top of a backfilled hole located within the infinite array would be collected. The particular package used in this experiment would be buried directly in the salt (with nc hole liner or secondary container) and covered with fine, crushed salt backfill. If the $t h$ production rate became sufficient to promote the formation of explosive mixtures in the backfilled rooms, then the second experiment shoulc be considered. The second experimert would be conducted with a acisfilled room containing severa? waste jackages buried directlv in the salt. imall-diameter gas sample tubes would extend from the entrance of the room to different locations along the length of the room. Gas samples would be taken periodically to determine the concentrations.

The two experiments will also be useful for determining concentrations of noxious gases such as $\mathrm{HCl}$. Caiculations indicate that the concentrations of these gases will be well below acceptable limits, but confirmation of this fact is needad.

As a part of these experiments, some indication of brine flow rate will be obtained by collecting moisture from the upper regions of the backfilled hole during the later stages of the experiment. The removal of moisture from the backfill would be accomplished with electric heaters. The data obtained will provide information required for an estimate of total brine inflow.

\subsubsection{Fis:ion Product Transport}

Once the primary container of a buried bare waste package is breached, there j.s a remote possibility tiat radioisotopes will migrate through the backfill to working areas during repository operation, and an even more remote possibility that some'will migrate beyond the original isundaries 
long after closure of the repository. Laboratory experiments indicate that significart migration is highly improbable. However, it is of interest to confirm some aspects of the laboratory findings hy conducting in-situ experiments. Three basic experiments of this nature are proposed in the pilot plant.

(1) Gas Transport Caaracteristius of the Bedded Salt. - Two experiments are proposel. Each requires the drilling of two holes, one into the floor of a room in the midst of the infinite array and one at a location isolated from the array. In the first experiment, both holes will be capped and the increase in radon concentration in the holes will be observed. In the second, gas pressure would be epplied to the holes, the system would be isolated, and the pressure decay rate would be observed. Each experiment is designed tc determine the permeability of the salt to gas.

(2) Gas Transport Characteristics of the Crushed Salt Backfill. This experiment will iavolve the injection of small amounts of a radioactive gas or hellier. into a backfilled hole near the surface of a directly buried waste package. Monitors will be used to determine the rate at wich these gases emanate from the top of the hole. This experiment will be conducted in two parts: (1) within the infinite array, and (2) in an isolated area.

(3) Transport of Kadioactive Fuclides Foilowing Breach of the Waste Container. - A waste package will be buried directly in the salt in an isolated mos, and the hole will be backfilled with fine crushed salt. Either prior to or following placement in the hole, the container will be breached, allowing waste to come in direct contact with the crushed salt. The top of the hole will be monitored for radioactive effluents, and cores wil? eventually be taken from the solid salt adjacent to the waste package. If significant release occurs irom the top of the hole, it may be desirable tc backfill the room and determine the transport rate into the corridor. I' is also possible that supplemental heat in the form of actual waste (in sleeved holes) or electric heaters will be desired to obtuin the higher temperatures associated with an infinite array. 


\subsubsection{Rock Mechanics}

The purpose of the overall rock methanics analysis program is to predict, as a function of t,1me, the deformations, stresses, and strains that will be imposed upon the various formations associated with an operational weste repository. This predictive capability will be obtained by extrapolation of a mathematical model which describes the rock behavicr. Since such a model would be based upon the in-situ deformational properties of the salt at the disposal horizon and the surrounding rocks, it will be necessary to determine these properties - to calibrate the model - by comparison with the known deformations around some fairly large excavations in the same or very similar geologic situation as that planned for the repositnry. The underground pilot plant area provides an ideal opportunity for obtaining those known deformations. Naturally, the effectiveness of the "calibration" of the mathematical model and the reliability of the predictions obtained with it will be increased as the area used, the number of installed heat, sources, and the period of observation are increased.

The objective of the rock mechanics instrumentstion network throughout the filot plant area is to provide the data for completely describing the deformations which cccur. Therefore, the details of tinis network will be highly dependent on both the design of the mine and the arrangement of the heat sources. While these details will be determined after the experimental design is finalized, it is anticipated that the instrumentation will consist primarily of a fairly large number of vertical room closure (convergence) gages augmented by a few arrays of horizontal and vertical rock strain gages, rock stress-change meters, and other instruments placed at particularly interesting locations.

\subsection{Retrieval of Directly Buried Waste}

The retrieval of directly buried waste will require special equipment that is not currently available. Before any waste is buried directly in the sali (without the secondary contriner and sleere), this equipment must be developed and demonstrated in the pilot plant using nonradioactive; simuiated waste packages. The demonstration will be performed with the 
simulated waste package and the surrounding salt at ambient temperatures and at elevated temperatures. Elevated temperatures will be achieved via electric heaters that will be disconnected prior to removal of the waste package.

The retrieval equipment is expected to consist of an overcoring device that will remove a core of solid salt containing the waste package. The oniy expected sensitivity to elevated temperature in this operation involres the cutting efficienc, and the closure of the freshly cut hole on the bit. If closure is significant, reamers on the side of the bit can be used to maintain adequate clearance. Thus, the only temperature that need be reproduced accurately is that at the radial location of the cutter. Under normal conditions, a period of several years is required for the temperature at this location to achieve its maximun value. However, since temperature distribution per se is not important, higher heat rates can be used to obtain the desired temperature in much shorter periods of time. 